\title{
Nickel-catalyzed Reductive Coupling of Heteroaryl and Aryl Chlorides
}

\author{
Bijan Mirabi, Austin D. Marchese, Mark Lautens* \\ Davenport Research Laboratories, Department of Chemistry, University of Toronto \\ 80 St. George St., Toronto, ON, M5S 3H6 \\ *Corresponding author: mark.lautens@utoronto.ca \\ Supporting Information
}

\section{Table of Contents}

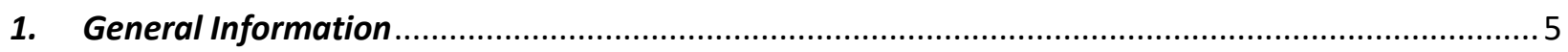

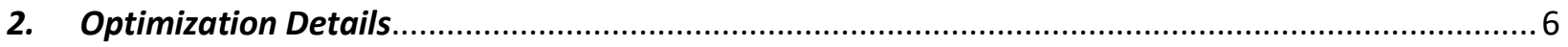

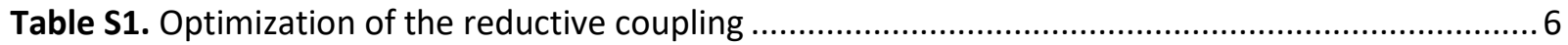

Table S2. Further optimization of the reductive coupling ............................................................ 8

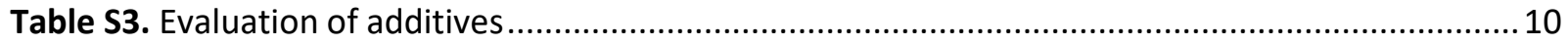

Table S4. Optimization of the reductive coupling reaction using N-methyl-2-chlorobenzimidazole ....11

Table S5. Further optimization of the reductive coupling reaction using N-methyl-2-

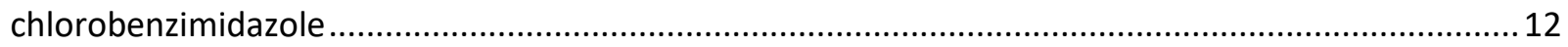

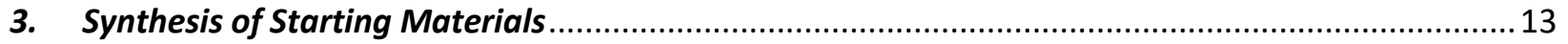

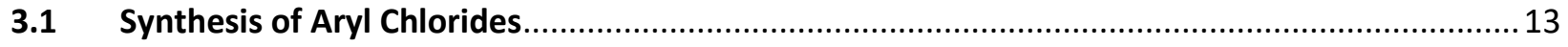

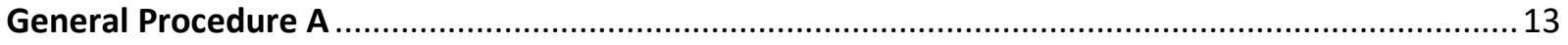

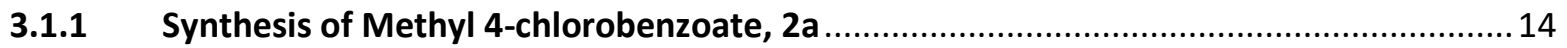

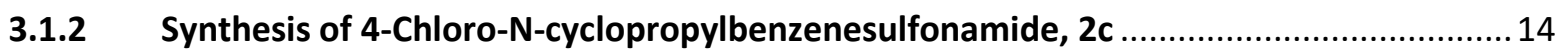

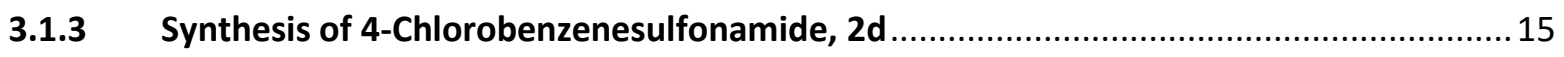

3.1.4 Synthesis of 1-((4-chlorophenyl)sulfonyl)-1,2,3,4-tetrahydroquinoline, $2 \mathrm{e}$.................15

3.1.5 Synthesis of (4-chlorophenyl)(4-phenylpiperazin-1-yl)methanone, 21 ........................16

3.1.6 Synthesis of ((3aR,5R,5aS,8aS,8bR)-2,2,7,7-tetramethyltetrahydro-5H-

bis([1,3]dioxolo)[4,5-b:4',5'-d]pyran-5-yl)methyl 4-chlorobenzoate, $2 \mathrm{~m}$..................................... 16

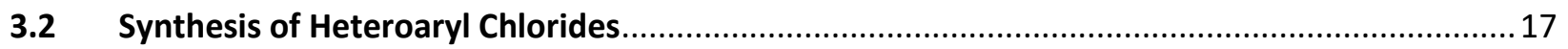

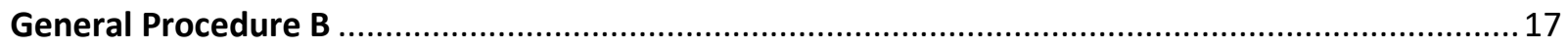

3.2.1 Synthesis of 2-Chloro-1-methylbenzimidazole, 1a.................................................. 18

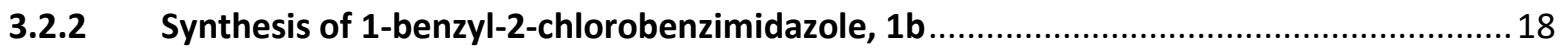

3.2.3 Synthesis of 1-(2-fluorobenzyl)-2-chlorobenzimidazole, 1d .......................................19 
3.2.4 Synthesis of methyl 3-(6-chloro-3-methyl-4-oxo-3,4-dihydroquinazolin-2-yl)propanoate, 1f 19

3.2.5 Synthesis of 2-butyl-4-chloro- $\mathrm{N}$-methylimidazole-5-carbaldehyde, $1 \mathrm{j}$.......................2 21

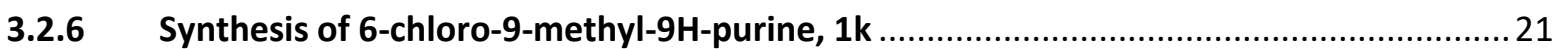

3.2.7 Synthesis of 4-chloro-7-methyl-7H-pyrrolo[2,3-d]pyrimidine, 11 ................................21

3.2.8 Synthesis of 2-chloro-1-(2-chlorobenzyl)-1H-benzo[d]imidazole, 1m...........................22

3.2.9 Synthesis of 2-chloro-1-(2-bromobenzyl)-1H-benzo[d]imidazole, 1n ..........................22

General Procedure C - Procedure for Cross-Electrophile Coupling of Heteroaryl and Aryl Chlorides 22 General Procedure D - Procedure for Cross-Electrophile Coupling of Heteroaryl and Aryl Chlorides23 General Procedure E - Procedure for Cross-Electrophile Coupling of Heteroaryl and Aryl Chlorides 23

3.3 Methyl 4-(1-methyl-1H-benzo[d]imidazol-2-yl)benzoate, 3aa .........................................24

3.4 Methyl 4-(1-benzyl-1H-benzo[d]imidazol-2-yl)benzoate, 3ba..........................................2 24

3.5 Methyl 4-(1H-benzo[d]imidazol-2-yl)benzoate, 3ca ......................................................2 24

3.6 Methyl 4-(1-(2-fluorobenzyl)-1H-benzo[d]imidazol-2-yl)benzoate, 3da ...........................25

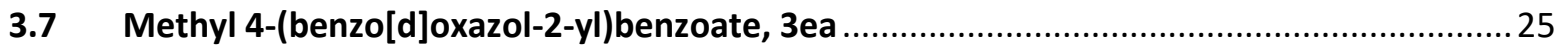

3.8 Methyl 4-(2-(3-methoxy-3-oxopropyl)-3-methyl-4-oxo-3,4-dihydroquinazolin-6-

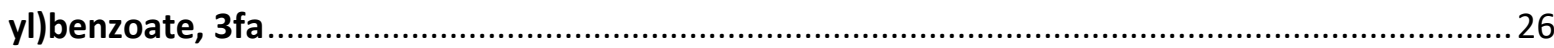

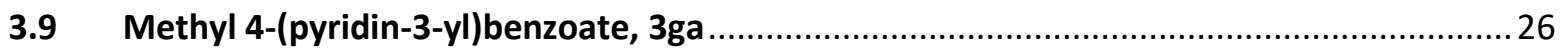

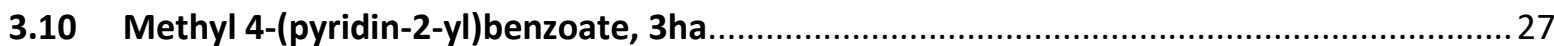

3.11 Methyl 4-(5,6-difluoropyridin-3-yl)benzoate, 3ia ........................................................2

3.12 Methyl 4-(2-butyl-5-formyl-1-methyl-1H-imidazol-4-yl)benzoate, 3ja .............................28

3.13 Methyl 4-(9-methyl-9H-purin-6-yl)benzoate, 3ka .........................................................28

3.14 Methyl 4-(7-methyl-7H-pyrrolo[2,3-d]pyrimidin-4-yl)benzoate, 3la...............................29

3.15 1-benzyl-2-(4-(trifluoromethyl)phenyl)-1H-benzo[d]imidazole, 3ma ..............................29

3.16 N-Cyclopropyl-4-(1-methyl-1H-benzo[d]imidazol-2-yl)benzenesulfonamide, 3na.............29

3.17 4-(1-methyl-1H-benzo[d]imidazol-2-yl)benzenesulfonamide, 30a ..................................30

3.18 1-((4-(1-methyl-1H-benzo[d]imidazol-2-yl)phenyl)sulfonyl)-1,2,3,4-tetrahydroquinoline, 3 pa 30

3.19 Ethyl 3-(1-methyl-1H-benzo[d]imidazol-2-yl)benzoate, 3qa .........................................31

3.20 1-(2-fluorobenzyl)-2-(4-(trifluoromethyl)phenyl)-1H-benzo[d]imidazole, 3ra .................. 31

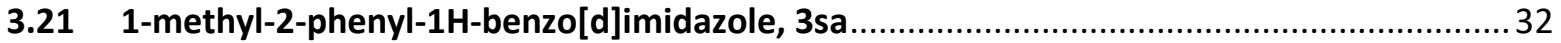

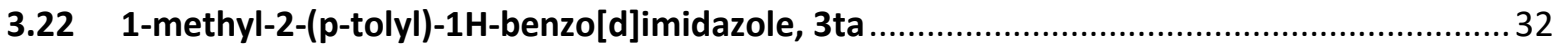

$3.23 \quad$ 2-(4-methoxyphenyl)-1-methyl-1H-benzo[d]imidazole, 3ua.............................................32

3.242 2-(benzo[d][1,3]dioxol-5-yl)-1-methyl-1H-benzo[d]imidazole, 3va .................................33 


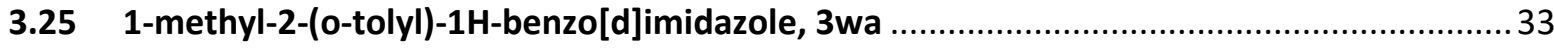

3.262 -([1,1'-biphenyl]-4-yl)-1-methyl-1H-benzo[d]imidazole, 3xa.........................................33

3.272 2-(3,5-dimethoxyphenyl)-1-methyl-1H-benzo[d]imidazole, 3ya ..................................... 34

3.28 1-methyl-2-(4-(trifluoromethyl)phenyl)-1H-benzo[d]imidazole, 3za ................................ 34

3.29 2-(2,5-dimethylphenyl)-1-methyl-1H-benzo[d]imidazole, 3ab.......................................... 34

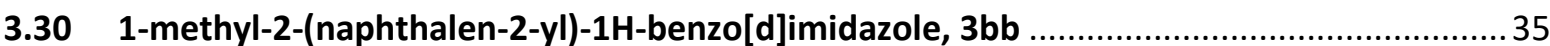

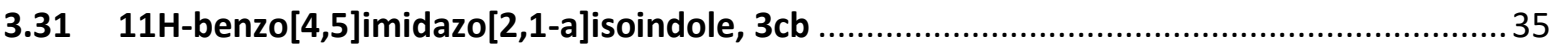

3.32 (4-(1-methyl-1H-benzo[d]imidazol-2-yl)phenyl)(4-phenylpiperazin-1-yl)methanone, 3db 36

3.33 ((3aR,5R,5aS,8aS,8bR)-2,2,7,7-tetramethyltetrahydro-5H-bis([1,3]dioxolo)[4,5-b:4',5'-

d]pyran-5-yl)methyl 4-(1-methyl-1H-benzo[d]imidazol-2-yl)benzoate, 3eb ............................... 36

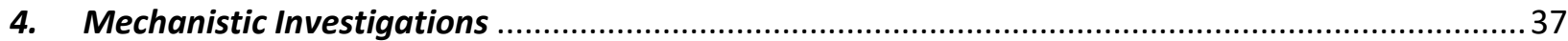

4.1 Control Experiments Confirming the Necessity of the Nickel Catalyst and $\mathrm{Zn}$......................37

5.1.1 Procedure for the Cross-Electrophile Coupling in the Absence of Nickel ......................37

5.1.2 Procedure for the Cross-Electrophile Coupling in the Absence of Zinc ...........................38

5.2 Testing for Possible Formation of Negishi-type Intermediates ...........................................38

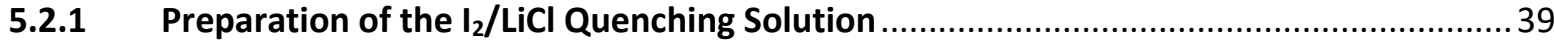

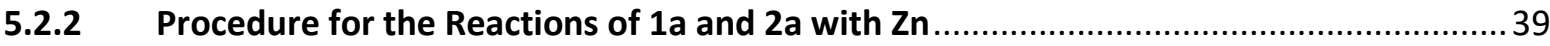

5.3 Testing for the Formation of Radical Intermediates......................................................... 39

5.3.2 Procedure for the Reactions of $1 \mathrm{a}$ and $2 \mathrm{a}$ in the presence of a radical scavenger ......... 40

5.4 Testing for Homocoupling of the Heteroaryl and Aryl Chloride ..........................................40

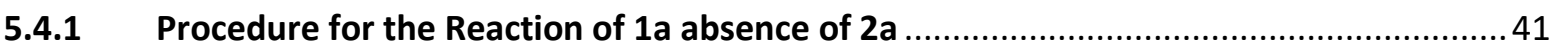

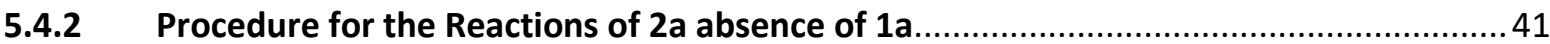

5.5 Testing for the Effect of lodide in the Reaction ............................................................. 41

5.5.1 Procedure for the Reaction in the Presence of Various Magnesium Salts .........................42

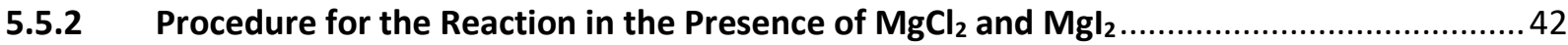

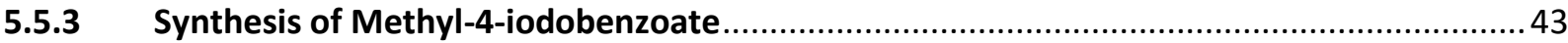

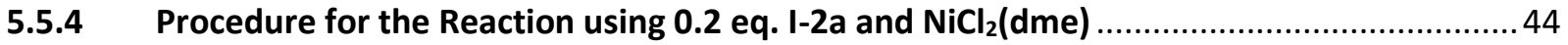

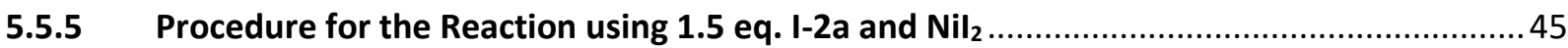

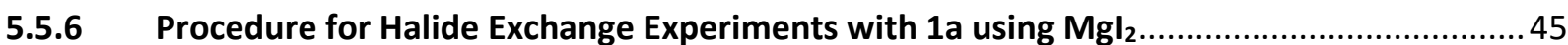

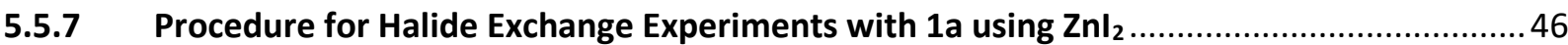

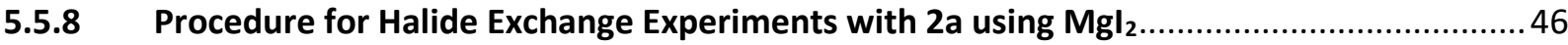

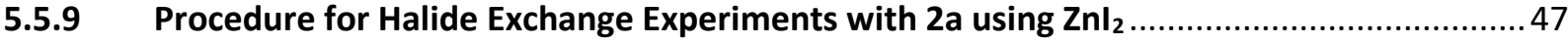

5.6 Stoichiometric Reactions using in situ Generated Nickel Complexes .................................. 47 
5.6.1 Procedure for the Reaction of 1a with Stoichiometric Nickel .......................................49

5.6.2 Procedure for the Reaction of 2a with Stoichiometric Nickel .........................................50

5.6.3 Procedure for the Reaction of $1 \mathrm{a}$ and $2 \mathrm{a}$ with Stoichiometric Nickel ...............................50

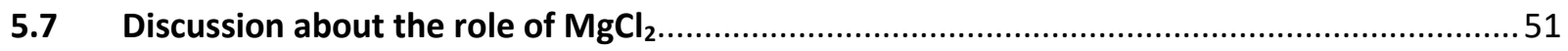

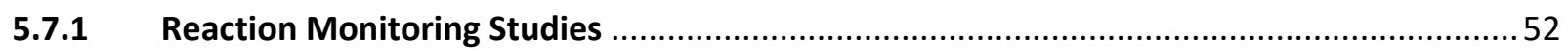

5.8 Using an Organic Reductant (TDAE) in the Cross-Electrophile Coupling ...............................54

5.8.1 Procedure for the Cross-Electrophile Coupling using TDAE as the Reductant ...................54

5.9 Using a Nickel ${ }^{0}$ Pre-Catalyst in the Cross-Electrophile Coupling .........................................5

5.9.1 Procedure for the Cross-Electrophile Coupling using Ni(COD)DQ in place of $\mathrm{Nil}_{2} \ldots \ldots \ldots \ldots . . . . .55$

5.9.2 Procedure for the Cross-Electrophile Coupling using $\mathrm{Ni}(\mathrm{COD}) \mathrm{DQ}$ in place of $\mathrm{Nil}_{2}$ and adding $\mathrm{MgI}_{2} \quad 55$

5.9.3 Stoichiometric Experiment using Ni(COD)DQ and 1a, followed by Addition of 2a ............55

5.9.4 Stoichiometric Experiment using Ni(COD)DQ and 1a, followed by Addition of 1a ............56

5.9.5 Stoichiometric Experiment using Ni(COD)DQ and 2a, followed by Addition of 1a ............57

5.9.6 Stoichiometric Experiment using Ni(COD)DQ and 2a, followed by Addition of 2a ............58

5.9.7 Stoichiometric Experiment using Ni(COD)DQ and 2a, followed by Addition of 1a and 2a .58

5.9.8 Summary of the Stoichiometric Experiments using Ni(COD)DQ ...................................59

$5.10{ }^{1} \mathrm{H}$ NMR Spectrum of the Crude Reaction between a Heteroaryl Chloride and an Electron-Rich

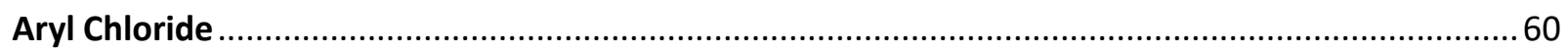

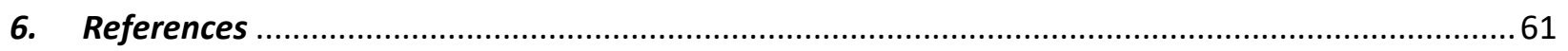

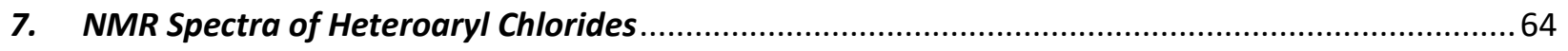

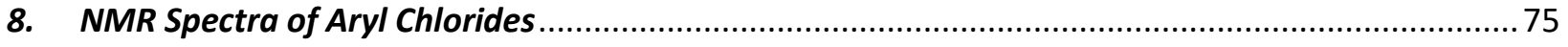

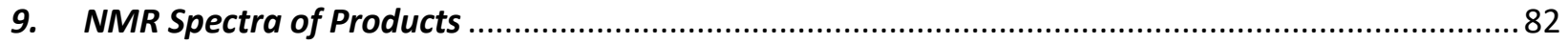




\section{General Information}

Unless otherwise stated, all manipulations were carried out under an inert atmosphere of dry argon or nitrogen utilizing glassware that was either oven $\left(120^{\circ} \mathrm{C}\right)$ or flame-dried. Workups and isolation of the products was conducted on the benchtop using standard techniques. Flash column chromatography ${ }^{1}$ was performed on Silicycle ${ }^{\circledR}$ Siliaflash $^{\circledast}$ P60, 40-63 $\mu$ m silica gel. Reactions were monitored using thin-layer chromatography (TLC) on SiliaPlate ${ }^{\mathrm{TM}}$ Silica Gel 60 F254 plates. Visualization of the plates was performed under UV light ( $254 \mathrm{~nm}$ ) or using $\mathrm{KMnO}_{4}$ stains. Starting materials and catalysts were purchased from commercial suppliers (MilliporeSigma, Strem, Alfa Aesar, TCl, Combi-Blocks, or Oakwood Chemicals) and used without further purification, unless otherwise stated.

Acetonitrile was distilled over calcium hydride, and 1,4-dioxane was distilled from purple sodium benzophenone ketyl prior to use. $\mathrm{N}, \mathrm{N}^{\prime}$-dimethylpropyleneurea (DMPU) was degassed via 3 freeze-pumpthaw cycles and stored over $3 \AA$ molecular sieves. Anhydrous N,N-dimethylformamide (DMF) was purchased in AcrosSeal bottles from Fisher Scientific and N,N-dimethylacetamide was purchased in Sure/SealT ${ }^{\mathrm{TM}}$ bottles from MilliporeSigma (used as received).

Mono- and multidimensional NMR characterization data were collected at $298 \mathrm{~K}$ on a Varian Mercury 300, Varian Mercury 400, Bruker Avance III 400, Agilent DD2 500 (with cryo probe), or an Agilent DD2 600 (funded by the Canadian Foundation for Innovation, project number 19119, and the Ontario MRI). ${ }^{1} \mathrm{H}$ NMR spectra were internally referenced to the residual solvent peak $\left(\mathrm{CDCl}_{3}=7.26 \mathrm{ppm}, \mathrm{DMSO}-d_{6}=2.50 \mathrm{ppm}\right)$. ${ }^{13} \mathrm{C}\left\{{ }^{1} \mathrm{H}\right\}$ NMR spectra were internally referenced to the solvent peak $\left(\mathrm{CDCl}_{3}=77.16 \mathrm{ppm}, \mathrm{DMSO}-d_{6}=39.52\right.$ ppm). ${ }^{19} \mathrm{~F}$ NMR chemical shifts are reported in ppm with absolute reference to ${ }^{1} \mathrm{H}$. NMR data are reported as follows: chemical shift ( $\delta \mathrm{ppm})$, multiplicity ( $\mathrm{s}=$ singlet, $\mathrm{d}=$ doublet, $\mathrm{t}=$ triplet, $\mathrm{q}=$ quartet, $\mathrm{m}=$ multiplet, $\mathrm{br}=$ broad), coupling constant $(\mathrm{Hz})$, integration. Coupling constants have been rounded to the nearest $0.05 \mathrm{~Hz}$. NMR yields were obtained by ${ }^{1} \mathrm{H}$ NMR analysis of the crude reaction mixture using a 10 second delay and 1,3,5-trimethoxybenzene as the internal standard. The NMR spectra were recorded at the NMR facility of the Department of Chemistry at the University of Toronto (https://sites.chem.utoronto.ca/csicomp/).

Infrared spectra were recorded on a Perkin-Elmer Spectrum 100 instrument equipped with a singlebounce diamond/ZnSe ATR accessory and are reported in wavenumber $\left(\mathrm{cm}^{-1}\right)$ units.

Melting point ranges were determined on a Fisher-Johns melting point apparatus and are reported uncorrected.

High resolution mass spectra (HRMS) were obtained on a JEOL JMS-T200GC AccuTOF GCx plus(EI) or an Agilent 6538 UHD Q-TOF (ESI) or a JEOL JMS-100LP AccuTOFLC-plus 4G mass spectrometer equipped with an IONICS ${ }^{\circ}$ Direct Analysis in Real Time (DART) ion source at the Advanced Instrumentation for Molecular Structure (AIMS) facility of the Department of Chemistry at the University of Toronto (https://sites.chem.utoronto.ca/chemistry/facilities/massspec/about.htm). 


\section{Optimization Details}

Table S1. Optimization of the reductive coupling ${ }^{[a]}$

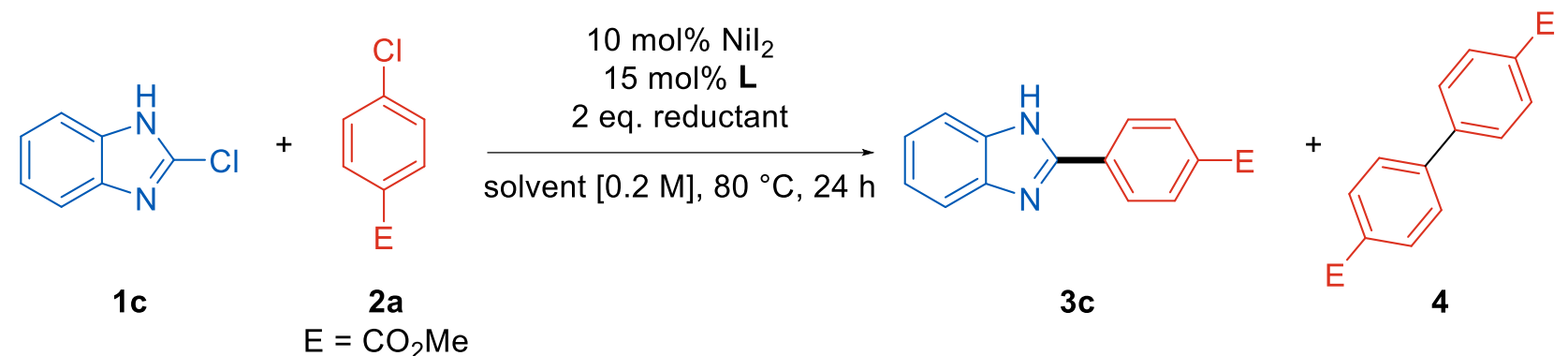<smiles>[R]c1ccnc(-c2cc([R])ccn2)c1</smiles>

$\mathrm{L} 1, \mathrm{R}=\mathrm{H}$ L2, $R=t B u$<smiles>c1cnc2c(c1)ccc1cccnc12</smiles>

L3<smiles>[R]C1COC(C(C)(C)C2=NC([R])CO2)=N1</smiles>

L4, $\mathrm{R}=i \mathrm{Pr}$ L5, $R=B n$<smiles>c1ccc(CC2COC(c3cccc(C4=N[C@@H](Cc5ccccc5)CO4)n3)=N2)cc1</smiles><smiles>N=C(N)c1cccc(C(=N)N)n1</smiles>

L6

L7

\begin{tabular}{|c|c|c|c|c|c|c|c|}
\hline Entry & Ligand & Reductant & Solvent & $\begin{array}{l}\text { Remaining } \\
\text { 1c }(\%)^{[b]}\end{array}$ & $\begin{array}{l}\text { Remaining } \\
2 \mathrm{a}(\%)^{[\mathrm{b}]}\end{array}$ & $\begin{array}{c}\text { Yield 3ca }(\%)^{[b]}\end{array}$ & $\begin{array}{c}\text { Yield } 4 \\
(\%)^{[b]}\end{array}$ \\
\hline $1^{[c]}$ & L1 & $\mathrm{Mn}$ & DMA & 0 & 0 & $21(21)$ & 77 \\
\hline 2 & L1 & $\mathrm{Mn}$ & DMA & 0 & 53 & 17 & 22 \\
\hline 3 & L1 & $\mathrm{Zn}$ & DMA & 0 & 36 & 40 & 0 \\
\hline 4 & L1 & $\mathrm{Zn}$ & DMF & 0 & 0 & $50(46)$ & 12 \\
\hline 5 & L1 & $\mathrm{Zn}$ & DMPU & 40 & 43 & $55(52)$ & 0 \\
\hline 6 & L1 & $\mathrm{Zn}$ & $\mathrm{MeCN}$ & 29 & 67 & 0 & 0 \\
\hline 7 & L1 & $\mathrm{Zn}$ & $\begin{array}{c}1,4- \\
\text { dioxane }\end{array}$ & 67 & 82 & 0 & 0 \\
\hline 8 & L2 & $\mathrm{Zn}$ & DMPU & 39 & 64 & 20 & 0 \\
\hline 9 & L3 & $\mathrm{Zn}$ & DMPU & 38 & 58 & 38 & 0 \\
\hline
\end{tabular}




\begin{tabular}{llllllll}
\hline 10 & L4 & Zn & DMPU & 37 & 78 & 13 & 0 \\
11 & L5 & Zn & DMPU & 66 & 77 & 13 & 0 \\
12 & L6 & Zn & DMPU & 62 & 98 & 0 & 0
\end{tabular}

[a] Reactions were carried out on $0.2 \mathrm{mmol}$ scale with a 1:1 ratio of 1c:2a. ${ }^{[b]}$ Yield was determined by ${ }^{1} \mathrm{H}$ NMR analysis of the crude reaction mixture following workup using 1,3,5-trimethoxybenzene as the internal standard. The yield of the isolated product is given in parentheses. ${ }^{[c]}$ The reaction was carried out using methyl 4-bromobenzoate in place of methyl 4-chlorobenzoate. 
Table S2. Further optimization of the reductive coupling ${ }^{[a]}$
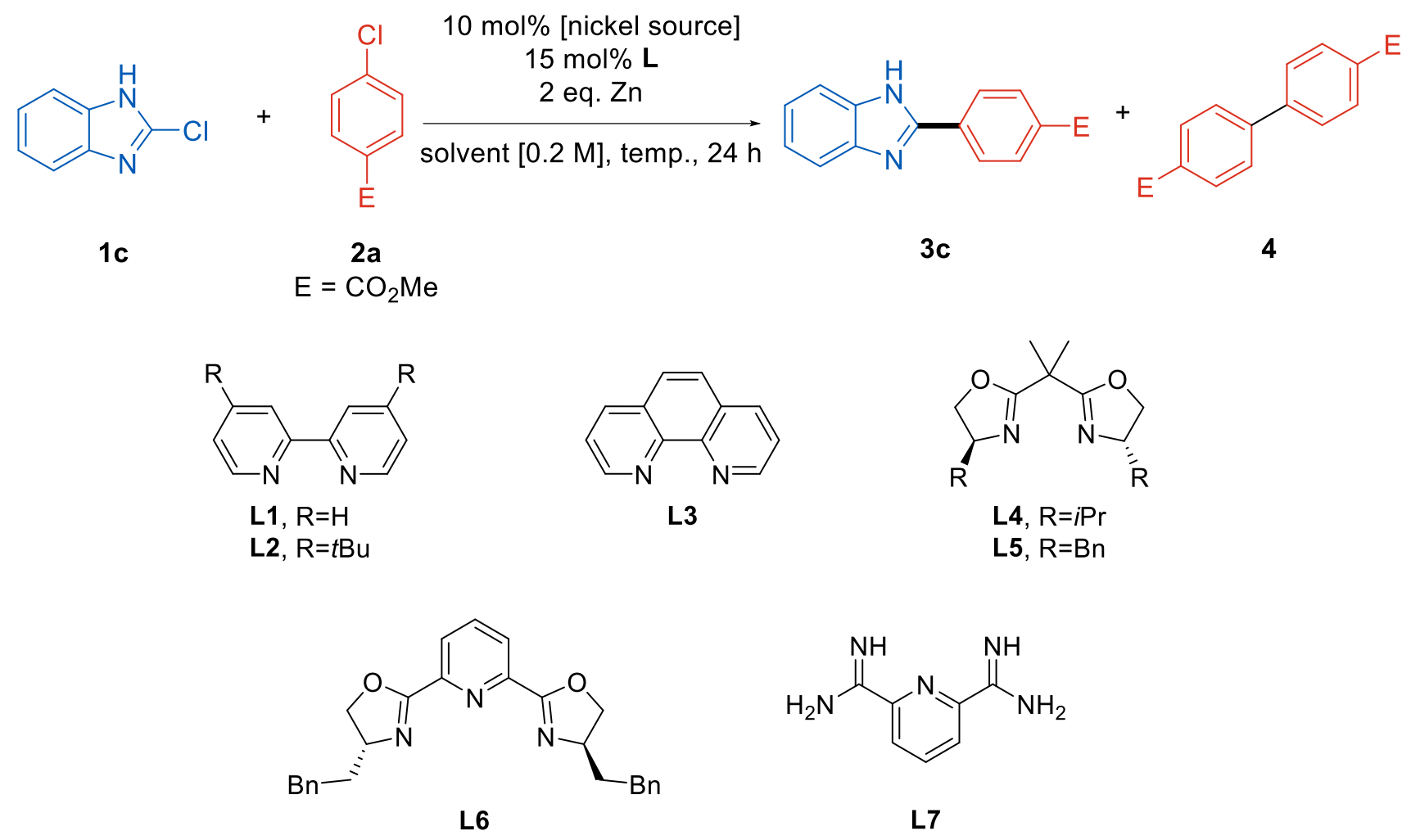

\begin{tabular}{|c|c|c|c|c|c|c|c|c|}
\hline Entry & Ligand & Solvent & $\begin{array}{l}\text { Temp } \\
\left({ }^{\circ} \mathrm{C}\right)\end{array}$ & $\begin{array}{l}\text { Nickel } \\
\text { source }\end{array}$ & $\begin{array}{c}\text { Remaining } \\
\text { 1c }(\%)^{[b]}\end{array}$ & $\begin{array}{l}\text { Remaining } \\
\text { 2a }(\%)^{[b]}\end{array}$ & $\begin{array}{l}\text { Yield 3c } \\
(\%)^{[b]}\end{array}$ & $\begin{array}{l}\text { Yield } 4 \\
(\%)^{[b]}\end{array}$ \\
\hline 1 & L1 & DMPU & 100 & $\mathrm{Nil}_{2}$ & 28 & 40 & 26 & 0 \\
\hline $2^{[c]}$ & L1 & dioxane & 100 & $\mathrm{NiBr}_{2}(\mathrm{dme})$ & 88 & 96 & 0 & 0 \\
\hline $3^{[\mathrm{d}]}$ & L1 & DMA & 100 & $\mathrm{NiBr}_{2}(\mathrm{dme})$ & 0 & 46 & 45 & 0 \\
\hline $4^{[e]}$ & L2 & DMA & 40 & $\mathrm{NiCl}_{2}(\mathrm{dme})$ & 27 & 32 & 10 & 13 \\
\hline $5^{[\mathrm{e}]}$ & L2 & $\begin{array}{c}2: 1 \\
\text { cyclohexane:DMA }\end{array}$ & 40 & $\mathrm{NiCl}_{2}(\mathrm{dme})$ & 15 & 58 & $<5$ & 0 \\
\hline $6^{[f]}$ & L1 & DMA & 90 & $\mathrm{Nil}_{2}$ & 0 & 12 & 29 & 0 \\
\hline $7^{[f]}$ & L1 & DMA & 100 & $\mathrm{Nil}_{2}$ & 0 & 11 & 21 & 0 \\
\hline $8^{[\mathrm{g}]}$ & L7 & DMPU & 80 & $\mathrm{Nil}_{2}$ & 23 & 75 & $<5$ & 0 \\
\hline
\end{tabular}

[a] Reactions were carried out on $0.2 \mathrm{mmol}$ scale with a 1:1 ratio of 1c:2a. ${ }^{[b]}$ Yield was determined by ${ }^{1} \mathrm{H}$ NMR analysis of the crude reaction mixture following workup using 1,3,5-trimethoxybenzene as the internal standard. The yield of the isolated product is given in parentheses. ${ }^{[c]}$ The reaction was carried out using a 1.3:1 ratio of $\mathbf{1 c}: 2 \mathrm{a}$. 3 equivalents of zinc dust and 0.75 equivalents of TMSCl were added. [d] The reaction was carried out using a 1.3:1 ratio of 1c:2a. [e] The reaction was carried out using a 1.5:1 ratio of 1c:2a. Methyl 4-bromobenzoate was used in place of methyl 4-chlorobenzoate, and 0.2 equivalents of $\mathrm{NaBF}_{4} \mathrm{Was}$ added. 
${ }^{[f]}$ The reaction was carried out using a 1.5:1 ratio of $1 \mathrm{c}: 2 \mathrm{a} .{ }^{\mathrm{g}]}$ The reaction was carried out using a 1.06:1 ratio of $1 \mathrm{c}: 2 \mathrm{a}, 1$ equivalent of $\mathrm{LiCl}$, and $10 \mathrm{~mol} \%$ of $\mathbf{L 7}$. 
Table S3. Evaluation of additives ${ }^{[a]}$<smiles>Fc1ccc(Cl)cc1</smiles>

1c

$2 a$

$10 \mathrm{~mol} \% \mathrm{Nil}_{2}$ $15 \mathrm{~mol} \%$ L1

2 eq. $\mathrm{Zn}$

DMPU [0.2 M], $80^{\circ} \mathrm{C}, 24 \mathrm{~h}$ $x$ eq. additive

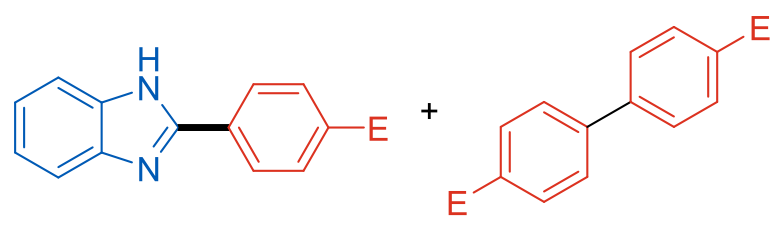

$3 c a$

4

\begin{tabular}{|c|c|c|c|c|c|c|}
\hline Entry & $x$ & Additive & Remaining $1 \mathrm{c}(\%)^{[\mathrm{b}]}$ & Remaining 2a (\%) ${ }^{[b]}$ & Yield 3ca (\% $)^{[b]}$ & Yield $4(\%)^{[b]}$ \\
\hline 1 & 0.75 & $\mathrm{TMSCl}$ & 33 & 59 & 33 & 0 \\
\hline 2 & 1 & DMAP & 8 & 82 & 4 & 0 \\
\hline 3 & 1 & pyridine & 45 & 87 & 14 & 0 \\
\hline 4 & 1 & $\mathrm{LiCl}$ & 22 & 55 & 23 & 0 \\
\hline 5 & 1 & $\mathrm{ZnCl}_{2}$ & 23 & 70 & 27 & 0 \\
\hline
\end{tabular}

${ }^{\text {[a] }}$ Reactions were carried out on $0.2 \mathrm{mmol}$ scale with a 1:1 ratio of 1c:2a. ${ }^{[b]}$ Yield was determined by ${ }^{1} \mathrm{H}$ NMR analysis of the crude reaction mixture following workup using 1,3,5-trimethoxybenzene as the internal standard. The yield of the isolated product is given in parentheses. 
Table S4. Optimization of the reductive coupling reaction using N-methyl-2-chlorobenzimidazole ${ }^{[a]}$

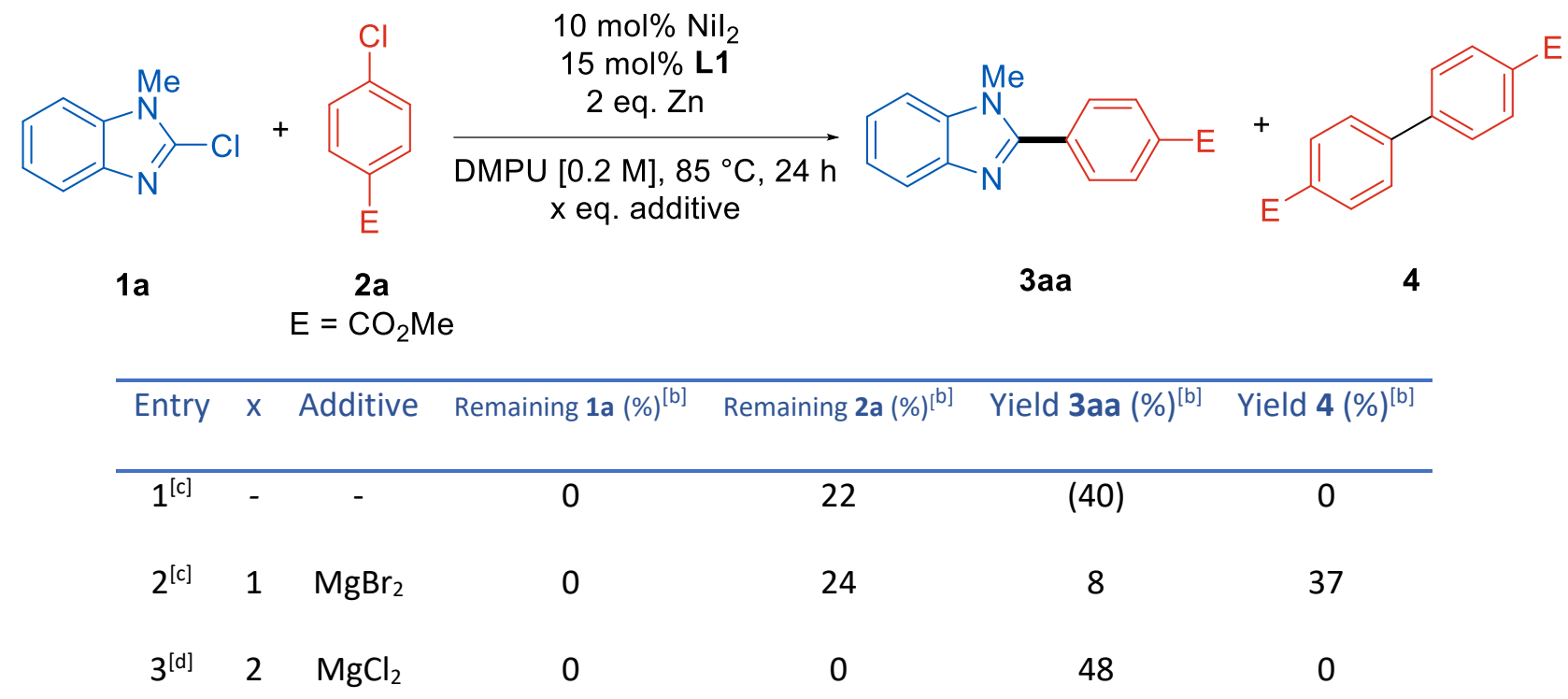

[a] Reactions were carried out on $0.2 \mathrm{mmol}$ scale with a 1:1.5 ratio of 1a:2a. ${ }^{\mathrm{b}]}$ Yield was determined by ${ }^{1} \mathrm{H}$ NMR analysis of the crude reaction mixture following workup using 1,3,5-trimethoxybenzene as the internal standard. The yield of the isolated product is given in parentheses. ${ }^{[c]}$ The reaction was carried out using a 1.5:1 ratio of 1a:2a. ${ }^{[d]}$ The reaction was carried out using a $1: 1.5$ ratio of $1 \mathbf{a}: 2 a$. 
Table S5. Further optimization of the reductive coupling reaction using N-methyl-2-chlorobenzimidazole ${ }^{[a]}$<smiles>Cn1c(Cl)nc2ccccc21</smiles>
$10 \mathrm{~mol} \%$ [nickel source] 15 mol\% L1 2 eq. $\mathrm{Zn}$ DMF [0.2 M], $85^{\circ} \mathrm{C}, 24 \mathrm{~h}$ $\mathrm{x}$ eq. $\mathrm{MgCl}_{2}$<smiles>Cn1c(-c2ccc(F)cc2)nc2ccccc21</smiles>

$3 a$

4 $\mathrm{E}=\mathrm{CO}_{2} \mathrm{Me}$

\begin{tabular}{|c|c|c|c|c|c|c|}
\hline Entry & $\begin{array}{l}\text { Nickel } \\
\text { source }\end{array}$ & $x$ & $\begin{array}{l}\text { Remaining 1a } \\
\left(^{[\mathrm{b})^{[b]}}\right.\end{array}$ & $\begin{array}{c}\text { Remaining 2a } \\
(\%)^{[b]}\end{array}$ & $\begin{array}{c}\text { Yield 3aa } \\
(\%)^{[b]}\end{array}$ & Yield $4(\%)^{[b]}$ \\
\hline 1 & $\mathrm{Nil}_{2}$ & 1 & 0 & 0 & (54) & 13 \\
\hline $2^{[c]}$ & $\mathrm{NiBr}_{2}$ (bipy) & 1 & 0 & 0 & (43) & $-[d]$ \\
\hline 3 & $\mathrm{NiCl}_{2}(\mathrm{dme})$ & 1 & 0 & 0 & 38 & 12 \\
\hline 4 & $\mathrm{Nil}_{2}$ & 2 & 0 & 0 & $96(90)$ & 7 \\
\hline 5 & $\mathrm{Nil}_{2}$ & 4 & 0 & 0 & 90 & 5 \\
\hline $6^{[\mathrm{e}]}$ & $\mathrm{Nil}_{2}$ & 1 & 0 & 0 & 49 & $<5$ \\
\hline $7^{[f]}$ & $\mathrm{Nil}_{2}$ & 1 & 0 & 12 & 44 & $<5$ \\
\hline $8^{[\mathrm{g}]}$ & $\mathrm{Ni}_{2}$ & 1 & 0 & $<5$ & 45 & $<5$ \\
\hline $9^{[h]}$ & $\mathrm{Nil}_{2}$ & 1 & 0 & 50 & 27 & 0 \\
\hline $10^{[i]}$ & $\mathrm{Nil}_{2}$ & 2 & 0 & 0 & 76 & 26 \\
\hline
\end{tabular}

[a] Reactions were carried out on $0.2 \mathrm{mmol}$ scale with a 1:1.5 ratio of 1a:2a. ${ }^{[b]}$ Yield was determined by ${ }^{1} \mathrm{H}$ NMR analysis of the crude reaction mixture following workup using 1,3,5-trimethoxybenzene as the internal standard. The yield of the isolated product is given in parentheses. [c] The reaction was carried out using preformed $\mathrm{NiBr}_{2}$ (bipy). No ligand was added in this case. [d] The crude reaction was purified following workup without the addition of 1,3,5-trimethoxybenzene. TLC monitoring of the reaction indicated complete consumption of $\mathbf{1 a}$ and $\mathbf{2 a}$. Some amounts of $\mathbf{4}$ was observed. [e] The reaction was carried out using DMF at a concentration of $0.1 \mathrm{M}$. [f] The reaction was carried out using DMF at a concentration of $0.4 \mathrm{M}$. [g] The reaction was carried out using a 1:1 ratio of 1a:2a. ${ }^{[h]}$ The reaction was carried out at $40{ }^{\circ} \mathrm{C}$. ${ }^{[i]}$ The reaction was carried out using $20 \mathrm{~mol} \% \mathbf{L 1}$ 


\section{Synthesis of Starting Materials}

\subsection{Synthesis of Aryl Chlorides}

Aryl chlorides $\mathbf{2 b}, \mathbf{2 g}, \mathbf{2 f}, \mathbf{2} \mathbf{h}, \mathbf{2} \mathbf{j}, \mathbf{2 k}, \mathbf{2 l}, \mathbf{2} \mathrm{m}, \mathbf{2 n}$, and $\mathbf{2 0}$ were commercially available and purchased.

Scheme S1. Aryl chlorides evaluated in this study.<smiles>COC(=O)c1ccc(Cl)cc1</smiles>

$2 a$<smiles>FC(F)(F)c1ccc(Cl)cc1</smiles>

2b<smiles>O=S(=O)(NC1CC1)c1ccc(Cl)cc1</smiles>

2c<smiles>NS(=O)(=O)c1ccc(Cl)cc1</smiles>

2d<smiles>O=S(=O)(c1ccc(Cl)cc1)N1CCCc2ccccc21</smiles>

$2 e$

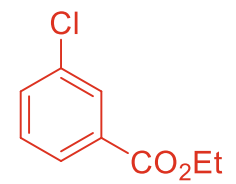

$2 f$<smiles>Clc1ccccc1</smiles>

$2 \mathrm{~g}$<smiles>Cc1ccc(Cl)cc1</smiles>

$2 \mathrm{~h}$<smiles>COc1ccc(Cl)cc1</smiles>

2i<smiles>Clc1ccc2c(c1)OCO2</smiles>

2j<smiles>Cc1ccccc1Cl</smiles>

2k<smiles>Clc1ccc(-c2ccccc2)cc1</smiles>

2I<smiles>COc1cc(Cl)cc(OC)c1</smiles>

$2 m$<smiles>Cc1ccc(C)c(Cl)c1</smiles>

$2 n$<smiles>Clc1ccc2ccccc2c1</smiles>

20<smiles>O=C(c1ccc(Cl)cc1)N1CCN(c2ccccc2)CC1</smiles>

$2 p$

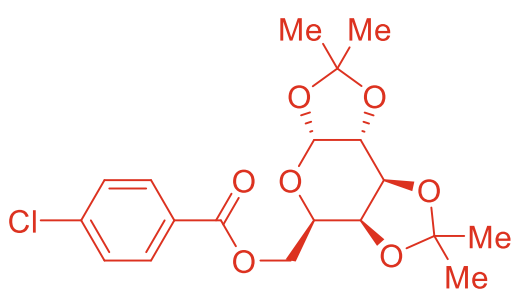

$2 q$

\section{General Procedure A}

Scheme S2. Synthesis of $\mathbf{2 l}$ and $\mathbf{2 m}$.

1.2 eq. $\mathrm{NucH}$<smiles>O=C(O)c1ccc(Cl)cc1</smiles>

1.1 eq. $\mathrm{EDC} \cdot \mathrm{HCl}$

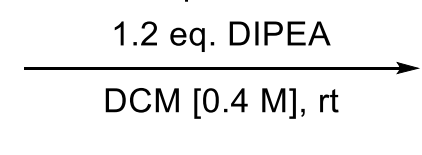<smiles>CNC(=O)c1ccc(Cl)cc1</smiles> 
This reaction was not performed under inert atmosphere and glassware was not flame- or ovendried. A round-bottomed flask was equipped with a PTFE-coated magnetic stir bar was charged with 4chlorobenzoic acid (1 eq.). DCM (0.4 M relative to 4-chlorobenzoic acid) was added, followed by sequential addition of the nucleophile (1.2 eq.), DIPEA (1.2 eq.) and then EDC. $\mathrm{HCl}$ (1.1 eq.). The reaction was stirred overnight at room temperature. Upon completion of the reaction, the solution was concentrated in vacuo. The residue was dissolved in EtOAc, washed twice with $1 \mathrm{M} \mathrm{HCl}$, once with a saturated solution of $\mathrm{NaHCO}_{3}$, and once with brine. The organic layer was dried over $\mathrm{MgSO}_{4}$ and then filtered; the filtrate was concentrated in vacuo. The crude material was purified by flash column chromatography.

\subsubsection{Synthesis of Methyl 4-chlorobenzoate, 2a}

Scheme S3. Synthesis of $2 a$<smiles>O=C(O)c1ccc(Cl)cc1</smiles>
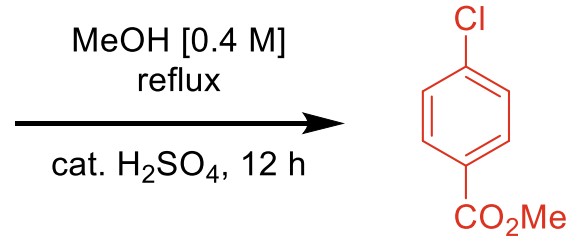

2a, $86 \%$ yield

This reaction was not performed under inert atmosphere and glassware was not flame- or ovendried. A round-bottomed flask equipped with a PTFE-coated magnetic stir bar was charged with 4chlorobenzoic acid (4.6970 g, $30.0 \mathrm{mmol}, 1$ eq.). Methanol was added at room temperature, followed by concentrated sulfuric acid ( 1 drop per mmol). The solution was stirred at a reflux for $12 \mathrm{~h}$. The solution was cooled to room temperature and then diluted with water and ethyl acetate. The mixture was poured into a separatory funnel and the organic layer was washed twice with a saturated aqueous solution of $\mathrm{NaHCO}_{3}$, once with water, and once with brine. The organic layer was dried over $\mathrm{MgSO}_{4}$ and then filtered; the filtrate was concentrated on a rotary evaporator. The crude material was purified by flash column chromatography (gradient elution, $0 \rightarrow 5 \%$ EtOAc in pentane) to afford $2 \mathrm{a}$ as a white solid $(4.3893 \mathrm{~g}, 86 \%$ yield). The spectroscopic data matched those reported in the literature. ${ }^{2}$

${ }^{1} \mathrm{H}$ NMR ( $\left.\mathrm{CDCl}_{3}, 500 \mathrm{MHz}\right): \delta 7.98-7.94(\mathrm{~m}, 2 \mathrm{H}), 7.43-7.36(\mathrm{~m}, 2 \mathrm{H}), 3.90(\mathrm{~s}, 3 \mathrm{H})$

${ }^{13} \mathrm{C}\left\{{ }^{1} \mathrm{H}\right\}$ NMR $\left(\mathrm{CDCl}_{3}, 125 \mathrm{MHz}\right): \delta 166.3,139.5,131.1,128.8,128.7,52.4$

\subsubsection{Synthesis of 4-Chloro-N-cyclopropylbenzenesulfonamide, 2c}

Scheme S4. Synthesis of 2c
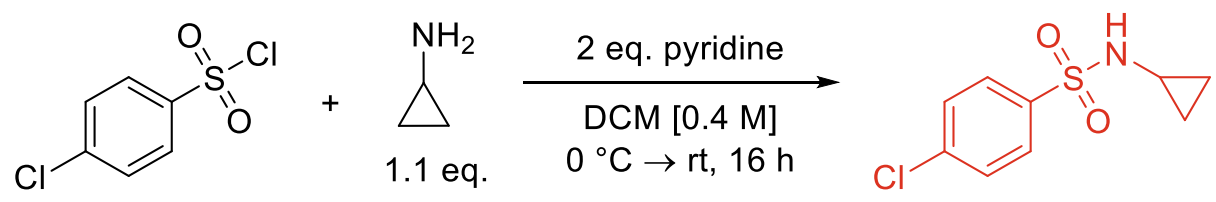

2c, $72 \%$ yield 
4-chlorobenzenesulfonyl chloride $(1.0553 \mathrm{~g}, 5.0 \mathrm{mmol}, 1 \mathrm{eq}$.) was added to a round-bottomed flask containing a PTFE-coated stir bar and was dissolved in DCM (12.5 mL). The colourless solution was cooled to $0{ }^{\circ} \mathrm{C}$ and then cyclopropylamine $(0.38 \mathrm{~mL}, 5.5 \mathrm{mmol}, 1.1 \mathrm{eq}$.) was added dropwise at the same temperature. The reaction mixture was allowed to warm to room temperature following the addition of the amine and was stirred for $16 \mathrm{~h}$. Following completion of the reaction, $1 \mathrm{M} \mathrm{HCl}$ was added and the reaction was poured into a separatory funnel. The aqueous layer was extracted three times with DCM. The combined organic layers were dried over $\mathrm{MgSO}_{4}$ and filtered; the filtrate was concentrated on a rotary evaporator. The crude material was purified by flash column chromatography ( $20 \%$ EtOAc in pentane) to afford $\mathbf{2 c}$ as a white solid ( $839.6 \mathrm{mg}, 72 \%$ yield).

${ }^{1} \mathrm{H} \mathrm{NMR}\left(\mathrm{CDCl}_{3}, 500 \mathrm{MHz}\right): \delta 7.84(\mathrm{~d}, J=8.6 \mathrm{~Hz}, 1 \mathrm{H}), 7.50(\mathrm{~d}, J=8.6 \mathrm{~Hz}, 1 \mathrm{H}), 5.14(\mathrm{~s}, 1 \mathrm{H}), 2.25$ (pd, J = 5.0, $1.5 \mathrm{~Hz}, 1 \mathrm{H}), 0.59(\mathrm{~d}, J=5.1 \mathrm{~Hz}, 3 \mathrm{H})$

${ }^{13} \mathrm{C}\left\{{ }^{1} \mathrm{H}\right\}$ NMR $\left(\mathrm{CDCl}_{3}, 125 \mathrm{MHz}\right): \delta$ 139.4, 138.3, 129.5, 129.0, 24.4, 6.3

IR (neat, cm cm: $^{-1}$ 3234, 3010, 2926, 1622, 1583, 1474, 1407, 1371, 1317, 1266, 1153, 1090, 1020, 962, 884, 823,754

Mass: DART, calc for $\mathrm{C}_{9} \mathrm{H}_{14} \mathrm{ClN}_{2} \mathrm{O}_{2} \mathrm{~S} 249.04590\left[\mathrm{M}+\mathrm{NH}_{4}\right]^{+}$, found 249.04588

Melting point: $92-94{ }^{\circ} \mathrm{C}$

\subsubsection{Synthesis of 4-Chlorobenzenesulfonamide, $2 \mathrm{~d}$}

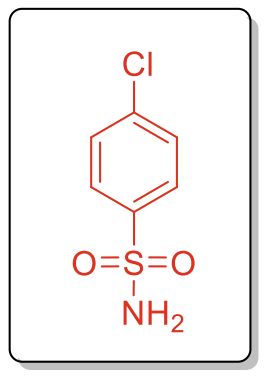

The title compound was prepared according to a literature procedure ${ }^{3}$ on a $2 \mathrm{mmol}$ scale. The crude material was purified by flash column chromatography (1:1 pentane:EtOAc) to afford $\mathbf{2 d}$ as a white solid ( $154.3 \mathrm{mg}, 40 \%$ yield). The spectroscopic data matched those reported in the literature. ${ }^{4}$

${ }^{1} \mathrm{H}$ NMR (DMSO- $\left.\boldsymbol{d}_{6}, 500 \mathrm{MHz}\right): \delta 7.86-7.80(\mathrm{~m}, 2 \mathrm{H}), 7.68-7.62(\mathrm{~m}, 2 \mathrm{H}), 7.47(\mathrm{~s}, 2 \mathrm{H})$.

${ }^{13} \mathrm{C}\left\{{ }^{1} \mathrm{H}\right\}$ NMR (DMSO- $\left.d_{6}, 125 \mathrm{MHz}\right): \delta 143.0,136.6,129.1,127.6$.

\subsubsection{Synthesis of 1-((4-chlorophenyl)sulfonyl)-1,2,3,4-tetrahydroquinoline, $2 \mathrm{e}$}

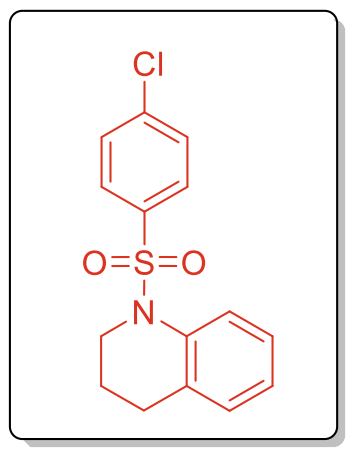

The title compound was prepared according to a literature procedure ${ }^{5}$ on a 6 $\mathrm{mmol}$ scale. The crude material was purified by flash column chromatography (5:1 pentane:EtOAc) to afford $2 \mathrm{e}$ as a white solid $(701.8 \mathrm{mg}, 38 \%$ yield). The spectroscopic data were consistent with those published in the literature. ${ }^{5}$

${ }^{1}$ H NMR (DMSO- $\left.\boldsymbol{d}_{6}, 500 \mathrm{MHz}\right): \delta 7.65-7.55(\mathrm{~m}, 5 \mathrm{H}), 7.23-7.16(\mathrm{~m}, 1 \mathrm{H}), 7.12-$ $7.04(\mathrm{~m}, 2 \mathrm{H}), 3.81-3.68(\mathrm{~m}, 2 \mathrm{H}), 2.43(\mathrm{t}, J=6.6 \mathrm{~Hz}, 2 \mathrm{H}), 1.60(\mathrm{dt}, J=12.6,6.6 \mathrm{~Hz}$, $2 \mathrm{H})$.

${ }^{13} \mathrm{C}\left\{{ }^{1} \mathrm{H}\right\}$ NMR (DMSO-d $\left.d_{6}, 125 \mathrm{MHz}\right): \delta 138.2,137.8,136.0,130.7,129.6,129.4$, $128.6,126.3,125.0,123.8,46.3,25.9,21.1$. 
IR (neat, cm ${ }^{-1}$ ): 2938, 1622, 1583, 1459, 1453, 1356, 1165, 1078, 832, 760, 678

Mass: DART, calc for $\mathrm{C}_{15} \mathrm{H}_{15} \mathrm{ClNO}_{2} 308.05065[\mathrm{M}+\mathrm{H}]^{+}$, found 308.05038

Melting point: $80-82^{\circ} \mathrm{C}$

\subsubsection{Synthesis of (4-chlorophenyl)(4-phenylpiperazin-1-yl)methanone, 2l}

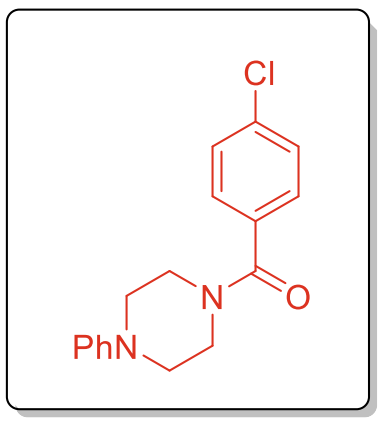

The title compound was prepared according to General Procedure $\mathbf{A}$ on a 1 mmol scale. 1-phenylpiperazine was used as the nucleophile. The crude material was purified by flash column chromatography ( $1: 1$ pentane:EtOAc) to afford $\mathbf{2 l}$ as a white solid (177.9 $\mathrm{mg}$, 59\% yield).

${ }^{1}{ }_{\mathrm{H}} \mathrm{NMR}\left(\mathrm{CDCl}_{3}, 500 \mathrm{MHz}\right): \delta 7.44-7.37(\mathrm{~m}, 4 \mathrm{H}), 7.32-7.25(\mathrm{~m}, 2 \mathrm{H}), 6.96-$ $6.89(\mathrm{~m}, 3 \mathrm{H}), 4.13-3.44(\mathrm{~m}, 4 \mathrm{H}), 3.40-2.95(\mathrm{~m}, 4 \mathrm{H})$.

${ }^{13} \mathrm{C}\left\{{ }^{1} \mathrm{H}\right\}$ NMR $\left(\mathrm{CDCl}_{3}, 125 \mathrm{MHz}\right): \delta 169.4,150.9,136.1,134.0,129.4,129.0$, $128.8,120.9,116.9,49.9,47.8,42.3$.

IR (neat, cm $^{-1}$ ): 2935, 2841, 1640, 1607, 1501, 1456, 1431, 1338, 1271, 1238, 1159, 1090, 999, 848, 754, 687

Mass: DART, calc for $\mathrm{C}_{17} \mathrm{H}_{18} \mathrm{ClN}_{2} \mathrm{O} 301.11022[\mathrm{M}+\mathrm{H}]^{+}$, found 301.11087

Melting point: $105-107^{\circ} \mathrm{C}$

3.1.6 Synthesis of ((3aR,5R,5aS,8aS,8bR)-2,2,7,7-tetramethyltetrahydro-5H-bis([1,3]dioxolo)[4,5b:4',5'-d]pyran-5-yl)methyl 4-chlorobenzoate, $2 \mathrm{~m}$

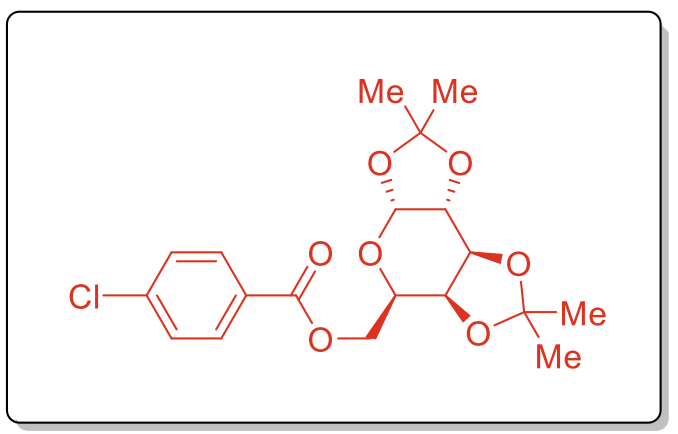

The title compound was prepared according to General Procedure A on a $2.2 \mathrm{mmol}$ scale. 1,2:3,4-di-Oisopropylidene- $\alpha$-D-galactopyranose was used as the nucleophile. The crude material was purified by flash column chromatography (1:1 pentane:EtOAc) to afford $\mathbf{2 m}$ as a white solid ( $317.2 \mathrm{mg}, 36 \%$ yield).

${ }^{1} \mathrm{H} \mathrm{NMR}\left(\mathrm{CDCl}_{3}, 500 \mathrm{MHz}\right): \delta 8.02-7.92(\mathrm{~m}, 2 \mathrm{H}), 7.43-7.37$ $(\mathrm{m}, 2 \mathrm{H}), 5.56(\mathrm{~d}, J=5.0 \mathrm{~Hz}, 1 \mathrm{H}), 4.65(\mathrm{dd}, J=7.9,2.5 \mathrm{~Hz}, 1 \mathrm{H})$, $4.52(\mathrm{dd}, J=11.6,4.6 \mathrm{~Hz}, 1 \mathrm{H}), 4.42(\mathrm{dd}, J=11.6,7.8 \mathrm{~Hz}, 1 \mathrm{H}), 4.34(\mathrm{dd}, J=5.0,2.5 \mathrm{~Hz}, 1 \mathrm{H}), 4.31$ (dd, J = 7.9, $1.9 \mathrm{~Hz}, 1 \mathrm{H}), 4.16(\mathrm{ddd}, J=7.8,5.0,1.9 \mathrm{~Hz}, 1 \mathrm{H}), 1.50(\mathrm{~s}, 3 \mathrm{H}), 1.47(\mathrm{~s}, 3 \mathrm{H}), 1.35(\mathrm{~s}, 3 \mathrm{H}), 1.33(\mathrm{~s}, 3 \mathrm{H})$.

${ }^{13} \mathrm{C}\left\{{ }^{1} \mathrm{H}\right\}$ NMR (CDCl $\left.3,125 \mathrm{MHz}\right): \delta 165.7,139.6,131.2,128.8,128.6,109.9,108.9,96.5,71.3,70.9,70.6$, $66.3,64.3,26.1,26.1,25.1,24.6$.

IR (neat, cm $^{-1}$ ): 2995, 2929, 2865, 1728, 1713, 1665, 1595, 1483, 1434, 1338, 1271, 1186, 1108, 830, 775 
Mass: DART, calc for $\mathrm{C}_{19} \mathrm{H}_{24} \mathrm{ClO}_{7} 399.12051[\mathrm{M}+\mathrm{H}]^{+}$, found 399.12037

Melting point: $84-86^{\circ} \mathrm{C}$

\subsection{Synthesis of Heteroaryl Chlorides}

Heteroaryl chlorides $\mathbf{1 c}, \mathbf{1 e}, \mathbf{1} \mathbf{g}, \mathbf{1} \mathbf{h}$, and $\mathbf{1 i}$ were commercially available and purchased.

Scheme S5. Heteroaryl chlorides evaluated in this study.

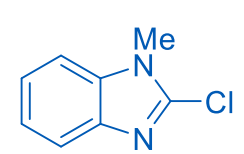

$1 \mathrm{a}$<smiles>Clc1nc2ccccc2[nH]1</smiles>

$1 b$<smiles>Clc1nc2ccccc2[nH]1</smiles>

$1 \mathrm{c}$<smiles>Fc1ccccc1Cn1c(Cl)nc2ccccc21</smiles>

$1 d$<smiles>Clc1nc2ccccc2o1</smiles>

$1 \mathrm{e}$<smiles>CC(=O)CCc1nc2ccc(Cl)cc2c(=O)n1C</smiles>

$1 f$<smiles>Clc1cccnc1</smiles>

$1 \mathrm{~g}$<smiles>Clc1ccccn1</smiles>

$1 \mathrm{~h}$<smiles>Fc1cc(Cl)cnc1F</smiles>

$1 \mathrm{i}$<smiles>CCCCc1nc(Cl)c(C=O)n1C</smiles>

$1 \mathrm{j}$<smiles>Cn1cnc2c(Cl)ncnc21</smiles>

$1 k$<smiles>Cn1ccc2c(Cl)ncnc21</smiles>

11<smiles>Clc1ccccc1Cn1c(Cl)nc2ccccc21</smiles>

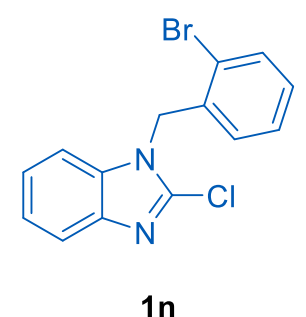

\section{General Procedure B}

Scheme S6. Reaction scheme for General Procedure A using 2-chlorobenzimidazole as the model heterocyclic chloride.<smiles>Clc1nc2ccccc2[nH]1</smiles>

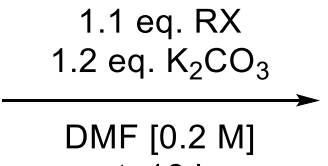<smiles></smiles>

rt, $16 \mathrm{~h}$

The unprotected heterocyclic chloride (1 eq.) was added to a round-bottomed flask containing a PTFE-coated stir bar, followed by addition of $\mathrm{K}_{2} \mathrm{CO}_{3}$ (1.2 eq.). DMF (0.2 $\mathrm{M}$ relative to the heterocycle) was 
added to the solids and the mixture was left to stir for 5 minutes. The alkyl halide (1.1 eq.) was added dropwise at room temperature and the reaction was stirred for $16 \mathrm{~h}$. The reaction was quenched by addition of water and then diluted with ethyl acetate. The mixture was poured into a separatory funnel and the organic layer was washed twice with water and three times with brine. The organic layer was dried over $\mathrm{MgSO}_{4}$ and filtered; the filtrate was concentrated on a rotary evaporator. The crude material was purified by flash column chromatography (conditions specified for each compound).

\subsubsection{Synthesis of 2-Chloro-1-methylbenzimidazole, 1a}

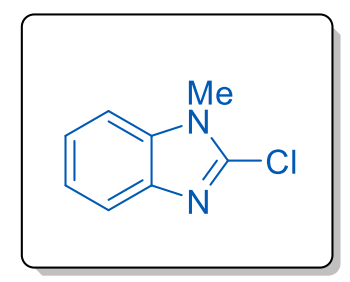

The title compound was synthesized according to General Procedure B on a $5.0 \mathrm{mmol}$ scale. lodomethane was added as the alkyl halide. The crude material was purified by flash column chromatography (gradient elution, $10 \rightarrow 30 \%$ EtOAc in pentane) to afford 1a as a white solid ( $691.5 \mathrm{mg}, 82 \%$ yield). The spectroscopic data matched those reported in the literature. ${ }^{6}$ The compound is also soluble in $\mathrm{CDCl}_{3}$ but the NMR resonances are not as well-resolved.

${ }^{1} \mathrm{H}$ NMR (DMSO-d $\mathrm{d}_{6}, 500 \mathrm{MHz}$ ): $\delta 7.59$ (dd, J = 7.9, $\left.1.2 \mathrm{~Hz}, 1 \mathrm{H}\right), 7.57-7.52(\mathrm{~m}, 1 \mathrm{H}), 7.31-7.27(\mathrm{~m}, 1 \mathrm{H})$, $7.26-7.21(\mathrm{~m}, 1 \mathrm{H}), 3.76(\mathrm{~s}, 3 \mathrm{H})$

${ }^{13} \mathrm{C}\left\{{ }^{1} \mathrm{H}\right\}$ NMR (DMSO-d 6 , $\left.125 \mathrm{MHz}\right): \delta$ 141.0, 140.2, 135.6, 122.8, 122.3, 118.4, 110.4, 30.4

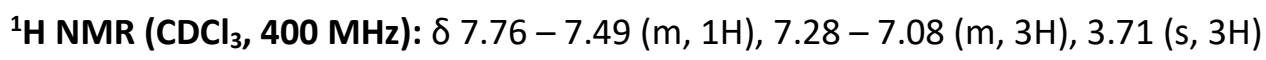

${ }^{13} \mathrm{C}\left\{{ }^{1} \mathrm{H}\right\}$ NMR $\left(\mathrm{CDCl}_{3}, 100 \mathrm{MHz}\right): \delta 141.6,141.0,135.6,123.2,122.7,119.4,109.2,30.5$

\subsubsection{Synthesis of 1-benzyl-2-chlorobenzimidazole, $1 \mathrm{~b}$}

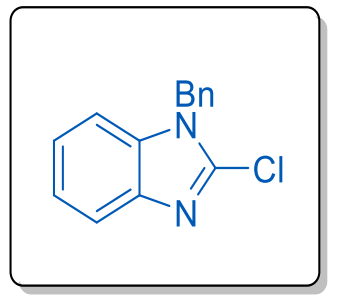

The title compound was synthesized according to General Procedure B on a $5.0 \mathrm{mmol}$ scale. Benzyl chloride was added as the alkyl halide. The crude material was purified by flash column chromatography (20\% EtOAc in pentane) to afford 1c as a white solid (1.0833 g, 90\% yield). The spectroscopic data matched those reported in the literature. ${ }^{7}$

${ }^{1}{ }^{H}$ NMR (DMSO-d $\left.6,500 \mathrm{MHz}\right): \delta 7.66-7.63(\mathrm{~m}, 1 \mathrm{H}), 7.63-7.59(\mathrm{~m}, 1 \mathrm{H}), 7.36-$ $7.31(\mathrm{~m}, 2 \mathrm{H}), 7.30-7.20(\mathrm{~m}, 5 \mathrm{H}), 5.52(\mathrm{~s}, 2 \mathrm{H})$

${ }^{13} \mathrm{C}\left\{{ }^{1} \mathrm{H}\right\}$ NMR (DMSO-d $\left.6125 \mathrm{MHz}\right): \delta 141.2,140.0,136.0,135.1,128.8,127.8,126.9,123.2,122.6,118.7$, $110.8,47.0$ 


\subsubsection{Synthesis of 1-(2-fluorobenzyl)-2-chlorobenzimidazole, $1 \mathrm{~d}$}

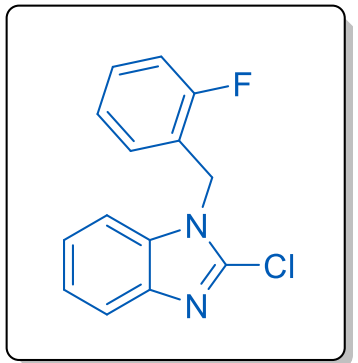

The title compound was synthesized according to General Procedure B on a 5.0 mmol scale. 2-fluorobenzyl chloride was added as the alkyl halide. The crude material was purified by flash column chromatography (30\% EtOAc in pentane) to afford $1 \mathrm{~d}$ as a white solid (1.2570 g, 96\% yield).

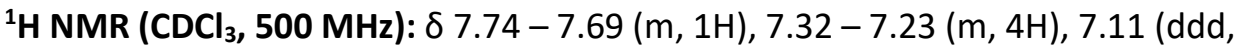
$J=9.9,8.3,1.2 \mathrm{~Hz}, 1 \mathrm{H}), 7.04(\mathrm{td}, J=7.5,1.2 \mathrm{~Hz}, 1 \mathrm{H}), 6.95(\mathrm{td}, J=7.6,1.7 \mathrm{~Hz}, 1 \mathrm{H})$,

$5.44(\mathrm{~s}, 2 \mathrm{H})$.

${ }^{13} \mathrm{C}\left\{{ }^{1} \mathrm{H}\right\}$ NMR $\left(\mathrm{CDCl}_{3}, 125 \mathrm{MHz}\right): \delta 160.3(\mathrm{~d}, J=247.0 \mathrm{~Hz}), 141.8,140.9,135.1,130.2(\mathrm{~d}, J=8.2 \mathrm{~Hz}), 128.7$

(d, $J=3.5 \mathrm{~Hz}$ ), 124.8 (d, $J=3.7 \mathrm{~Hz}$ ), 123.6, 123.1, 122.3 (d, $J=14.4 \mathrm{~Hz}$ ), 119.7, 115.8 (d, $J=21.1 \mathrm{~Hz}), 109.8$, $41.7(\mathrm{~d}, J=5.3 \mathrm{~Hz})$.

IR (neat, cm $^{-1}$ ): 2932, 2865, 1616, 1495, 1453, 1353, 1277, 1235, 1165, 1081, 969, 845, 760, 740, 702

Mass: DART, calc for $\mathrm{C}_{14} \mathrm{H}_{11} \mathrm{ClFN}_{2} 261.05893[\mathrm{M}+\mathrm{H}]^{+}$, found 261.05925

Melting point: $86-88^{\circ} \mathrm{C}$

3.2.4 Synthesis of methyl 3-(6-chloro-3-methyl-4-oxo-3,4-dihydroquinazolin-2-yl)propanoate, 1f Scheme S7. Synthesis of $\mathbf{1 f}$<smiles>Nc1ccc(Cl)cc1C(=O)O</smiles><smiles>NC(=O)c1cc(Cl)ccc1N</smiles>
$>99 \%$ yield

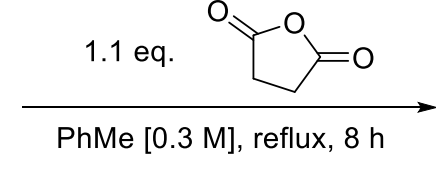

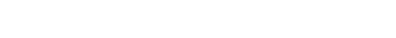

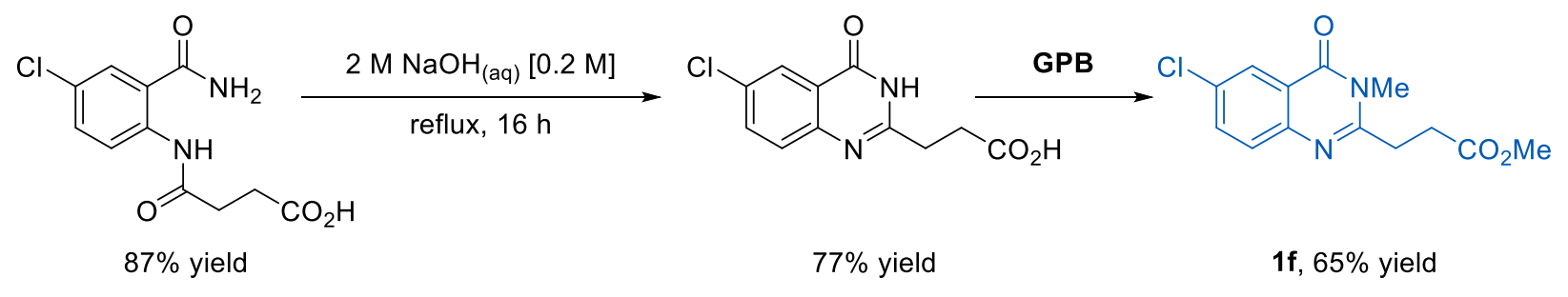

2-amino-5-chlorobenzoic acid (1 eq., $7.0 \mathrm{mmol}, 1.2011 \mathrm{~g}$ ) and carbonyldiimidazole (CDI) (1.5 eq., 10.5 mmol, $1.7026 \mathrm{~g}$ ) were added to a round-bottomed flask equipped with a PTFE-coated magnetic stir bar. The solids were dissolved in DCM $(14 \mathrm{~mL})$ and the flask was capped using a rubber septum pierced with an argon balloon. The solution was stirred at room temperature for 0.5 hours, after which $\mathrm{NH}_{4} \mathrm{OH}$ ( 10 eq., $70.0 \mathrm{mmol}, 2.75 \mathrm{~mL}$ ) was added dropwise at room temperature. After stirring for 2 hours, the argon 
balloon was removed and the solution was stirred vigorously for 14 hours. The reaction was concentrated in vacuo and the residue dissolved in EtOAc. The organic layer was washed twice with $1 \mathrm{M} \mathrm{HCl}$, once with a saturated aqueous solution of $\mathrm{NaHCO}_{3}$, and once with brine. The organics were dried over $\mathrm{MgSO}_{4}$ and filtered; the filtrate was concentrated in vacuo. The crude material was obtained in quantitative yield $(1.1942 \mathrm{~g})$ and used as is in the next step.

The anthranilamide ( 1 eq., $7.0 \mathrm{mmol}, 1.1942 \mathrm{~g}$ ) and succinic anhydride (1.1 eq., $7.7 \mathrm{mmol}, 770.5 \mathrm{mg}$ ) were added to a round-bottomed flask containing a PTFE-coated magnetic stir bar. The solids were dissolved in PhMe $(23.0 \mathrm{~mL}$ ) and the flask was equipped with a reflux condenser. The mixture was heated to reflux and stirred for 8 hours. The mixture was cooled to room temperature and the solids were collected by vacuum filtration. The material was washed thrice with diethyl ether and thrice with pentane. The crude material was obtained in $87 \%$ yield $(1.6490 \mathrm{~g})$ and used as is in the next step.

This reaction was not performed under inert atmosphere and glassware was not flame- or ovendried. The bis-amide was added to a round-bottomed flask containing a PTFE-coated magnetic stir bar and dissolved in $2 \mathrm{M} \mathrm{NaOH}_{(\mathrm{aq})}(30.5 \mathrm{~mL})$. The flask was equipped with a reflux condenser. The solution was heated to reflux and stirred for 16 hours. Upon completion of the reaction, the solution was acidified to $\mathrm{pH}$ 2-3 using concentrated $\mathrm{HCl}$, leading to the precipitation of a white solid. This solid was collected by vacuum filtration and was washed thrice with distilled water. The quinazolinone was dried in vacuo and used as is in the next step (1.1890 $\mathrm{g}, 77 \%$ yield).

The title compound was prepared according to General Procedure B on a $4.71 \mathrm{mmol}$ scale. The quinazolinone obtained in the previous step was used as the heterocyclic chloride and iodomethane was used as the alkyl halide. In this case, 2.2 eq. of iodomethane was used and 2.4 eq. of $\mathrm{K}_{2} \mathrm{CO}_{3}$ was used. The crude material was purified by flash column chromatography ( $50 \%$ EtOAc in pentane) to afford $\mathbf{1 f}$ as a white solid ( $854.5 \mathrm{mg}, 65 \%$ yield).

${ }^{1} \mathrm{H} \mathrm{NMR}\left(\mathrm{CDCl}_{3}, 500 \mathrm{MHz}\right): \delta 8.16(\mathrm{~d}, J=2.5 \mathrm{~Hz}, 1 \mathrm{H}), 7.59$ (dd, $\left.J=8.7,2.5 \mathrm{~Hz}, 1 \mathrm{H}\right), 7.49$ (d, $\left.J=8.7 \mathrm{~Hz}, 1 \mathrm{H}\right)$, $3.71(\mathrm{~s}, 3 \mathrm{H}), 3.61(\mathrm{~s}, 3 \mathrm{H}), 3.08(\mathrm{t}, J=6.7 \mathrm{~Hz}, 2 \mathrm{H}), 2.92(\mathrm{t}, J=6.7 \mathrm{~Hz}, 2 \mathrm{H})$.

${ }^{13} \mathrm{C}\left\{{ }^{1} \mathrm{H}\right\}$ NMR $\left(\mathrm{CDCl}_{3}, 125 \mathrm{MHz}\right): \delta$ 173.2, 161.4, 155.2, 145.5, 134.5, 132.2, 128.8, 126.1, 121.3, 52.0, 30.2, 30.0, 29.6.

IR (neat, cm $^{-1}$ ): 3062, 2938, 2866, 1743, 1679, 1607, 1586, 1495, 1475, 1463, 1416, 704

Mass: DART, calc for $\mathrm{C}_{13} \mathrm{H}_{14} \mathrm{ClN}_{2} \mathrm{O}_{3} 281.06875[\mathrm{M}+\mathrm{H}]^{+}$, found 281.06831

Melting point: $108-110^{\circ} \mathrm{C}$ 


\subsubsection{Synthesis of 2-butyl-4-chloro- $\mathrm{N}$-methylimidazole-5-carbaldehyde, $\mathbf{1 j}$}

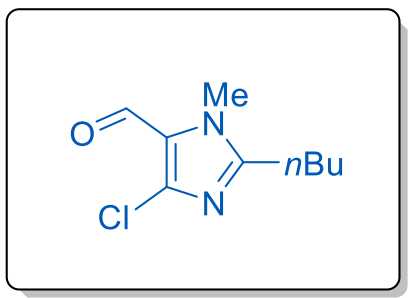

The title compound was prepared according to a literature procedure ${ }^{8}$ on a $3 \mathrm{mmol}$ scale. The crude material was purified by flash column chromatography (10:1 pentane:EtOAc) to afford $\mathbf{1} \mathbf{j}$ as a yellow oil. The spectroscopic data matches those reported in the literature. ${ }^{9}$

${ }^{1} \mathrm{H}$ NMR $\left(\mathrm{CDCl}_{3}, 500 \mathrm{MHz}\right): \delta 9.71(\mathrm{~d}, J=2.1 \mathrm{~Hz}, 1 \mathrm{H}), 3.83(\mathrm{~d}, J=1.7 \mathrm{~Hz}, 3 \mathrm{H})$, $2.65(\mathrm{ddd}, J=9.0,6.6,1.7 \mathrm{~Hz}, 2 \mathrm{H}), 1.81-1.62(\mathrm{~m}, 2 \mathrm{H}), 1.39(\mathrm{qd}, J=7.4,1.7 \mathrm{~Hz}, 2 \mathrm{H}), 0.93(\mathrm{td}, J=7.4,1.7$ $\mathrm{Hz}, 3 \mathrm{H})$.

${ }^{13} \mathrm{C}\left\{{ }^{1} \mathrm{H}\right\}$ NMR $\left(\mathrm{CDCl}_{3}, 125 \mathrm{MHz}\right): \delta$ 178.2, 154.1, 142.5, 124.9, 32.5, 29.2, 26.4, 22.5, 13.8.

\subsubsection{Synthesis of 6-chloro-9-methyl-9H-purine, $1 \mathrm{k}$}

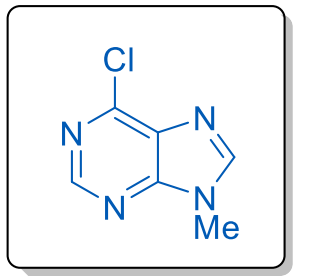

The title compound was prepared according to General Procedure B on a $3 \mathrm{mmol}$ scale. 6-chloropurine was used as the heterocyclic chloride and iodomethane was used as the alkyl halide. The crude material was purified by flash column chromatography (gradient elution, $0 \rightarrow 7 \% \mathrm{MeOH}$ in EtOAc) to afford $\mathbf{1} \mathbf{k}$ as a white solid ( $213.1 \mathrm{mg}, 42 \%)$. The spectroscopic data is consistent with previous literature reports. ${ }^{10}$

${ }^{1} \mathrm{H}$ NMR (DMSO-d $\left.{ }_{6}, 500 \mathrm{MHz}\right): \delta 8.73(\mathrm{~s}, 1 \mathrm{H}), 8.62(\mathrm{~s}, 1 \mathrm{H}), 3.85(\mathrm{~s}, 3 \mathrm{H})$.

${ }^{13} \mathrm{C}\left\{{ }^{1} \mathrm{H}\right\}$ NMR (DMSO- $\left.d_{6}, 125 \mathrm{MHz}\right): \delta 152.2,151.3,148.7,148.0,130.6,30.1$.

\subsubsection{Synthesis of 4-chloro-7-methyl-7H-pyrrolo[2,3-d]pyrimidine, 1 I}

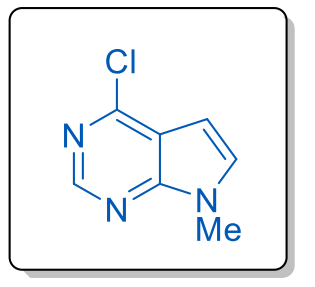

The title compound was prepared according to General Procedure B on a $2 \mathrm{mmol}$ scale. 6-chloro-7-deazapurine was used as the heterocyclic chloride and iodomethane was used as the alkyl halide. The crude material was purified by flash column chromatography (1:1 pentane:EtOAc) to afford $\mathbf{1 l}$ as a white solid (139.0 mg, $41 \%$ yield). The spectroscopic data is consistent with those reported in the literature. ${ }^{11}$

${ }^{1} \mathrm{H}$ NMR (DMSO-d $\left.\boldsymbol{d}_{6}, 500 \mathrm{MHz}\right): \delta 8.60(\mathrm{~s}, 1 \mathrm{H}), 7.69(\mathrm{~d}, J=3.6 \mathrm{~Hz}, 1 \mathrm{H}), 6.58(\mathrm{dd}, J=3.5,0.5 \mathrm{~Hz}, 1 \mathrm{H}), 3.83(\mathrm{~s}$, $4 H), 3.42-3.26(m, 1 H)$.

${ }^{13} \mathrm{C}\left\{{ }^{1} \mathrm{H}\right\}$ NMR (DMSO- $d_{6}, 125 \mathrm{MHz}$ ): $\delta$ 150.7, 150.4, 150.1, 132.2, 116.5, 98.1, 31.3. 


\subsubsection{Synthesis of 2-chloro-1-(2-chlorobenzyl)-1H-benzo[d]imidazole, $1 \mathrm{~m}$}

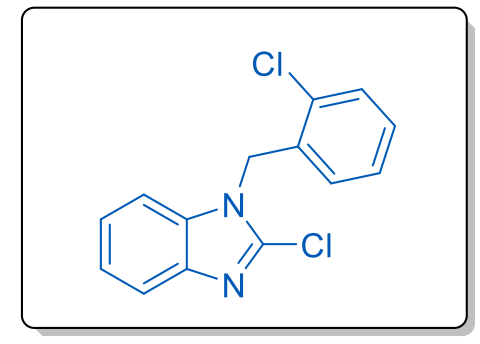

The title compound was prepared according to General Procedure B on a $2 \mathrm{mmol}$ scale. 2-chlorobenzimidazole was used as the heterocyclic chloride and 2-chlorobenzyl bromide was used as the alkyl halide. The crude material was purified by flash column chromatography (20\% EtOAc in pentane) to afford $1 \mathrm{~m}$ as a white solid ( $583.0 \mathrm{mg}, 96 \%$ yield). The spectroscopic data matched those reported in the literature. ${ }^{12}$

${ }^{1} \mathrm{H}$ NMR $\left(\mathrm{CDCl}_{3}, 500 \mathrm{MHz}\right): \delta 7.75$ (ddd, $\left.J=8.1,1.3,0.8 \mathrm{~Hz}, 1 \mathrm{H}\right), 7.44$ (dd, $J=8.1,1.3 \mathrm{~Hz}, 1 \mathrm{H}$ ), 7.29 (ddd, $J$ $=8.2,7.2,1.2 \mathrm{~Hz}, 1 \mathrm{H}), 7.24(\mathrm{ddt}, J=8.2,7.2,1.2 \mathrm{~Hz}, 1 \mathrm{H}), 7.18-7.14(\mathrm{~m}, 1 \mathrm{H}), 7.11(\mathrm{td}, J=7.6,1.2 \mathrm{~Hz}, 1 \mathrm{H})$, $6.61(\mathrm{ddt}, J=7.8,1.7,0.9 \mathrm{~Hz}, 1 \mathrm{H}), 5.48(\mathrm{~s}, 2 \mathrm{H})$.

${ }^{13} \mathrm{C}\left\{{ }^{1} \mathrm{H}\right\}$ NMR $\left(\mathrm{CDCl}_{3}, 125 \mathrm{MHz}\right): 141.8,141.1,135.1,132.6,132.4,129.9,129.4,127.5,127.2,123.7$, 123.2, 119.7, 109.9, 45.5.

\subsubsection{Synthesis of 2-chloro-1-(2-bromobenzyl)-1H-benzo[d]imidazole, 1n}

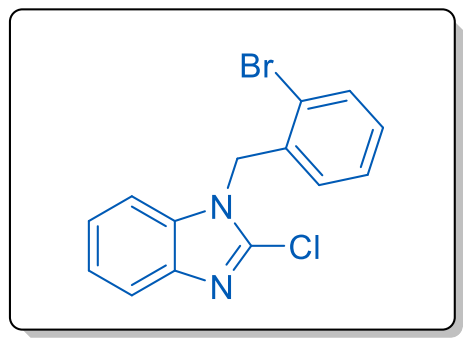

The title compound was prepared according to General Procedure B on a $1 \mathrm{mmol}$ scale. 2-chlorobenzimidazole was used as the heterocyclic chloride and 2-bromobenzyl bromide was used as the alkyl halide. The crude material was purified by flash column chromatography ( $20 \%$ EtOAc in pentane) to afford $1 \mathrm{n}$ as a white solid (301.8 $\mathrm{mg}, 94 \%$ yield).

${ }^{1} \mathrm{H}$ NMR $\left(\mathrm{CDCl}_{3}, 500 \mathrm{MHz}\right): \delta 7.78-7.71(\mathrm{~m}, 1 \mathrm{H}), 7.67-7.60(\mathrm{~m}, 1 \mathrm{H}), 7.29(\mathrm{ddd}, J=8.3,7.3,1.2 \mathrm{~Hz}, 1 \mathrm{H})$, $7.23(\mathrm{ddd}, J=8.3,7.3,1.2 \mathrm{~Hz}, 1 \mathrm{H}), 7.18-7.12(\mathrm{~m}, 3 \mathrm{H}), 6.58-6.50(\mathrm{~m}, 1 \mathrm{H}), 5.44(\mathrm{~s}, 2 \mathrm{H})$.

${ }^{13} \mathrm{C}\left\{{ }^{1} \mathrm{H}\right\}$ NMR $\left(\mathrm{CDCl}_{3}, 125 \mathrm{MHz}\right): \delta 141.8,141.1,135.1,134.1,133.2,129.6,128.1,127.2,123.7,123.2$, 122.1, 119.7, 109.9, 48.0 .

IR (neat, cm cm $^{-1}$ : 3065, 2938, 2868, 1616, 1501, 1456, 1441, 1371, 1353, 1329, 1280, 1247, 1196, 1044, 987, $805,778,826,745,696$

Mass: DART, calc for $\mathrm{C}_{14} \mathrm{H}_{11} \mathrm{BrClN}_{2} 320.97887[\mathrm{M}+\mathrm{H}]^{+}$, found 320.97870

Melting point: $96-98^{\circ} \mathrm{C}$

Nickel-catalyzed Cross-Electrophile Coupling of Aryl Chlorides

General Procedure C - Procedure for Cross-Electrophile Coupling of Heteroaryl and Aryl Chlorides

An oven-dried 2-dram vial was charged with a PTFE-coated stir bar and cooled under a positive pressure of argon. To the vial was added sequentially the heteroaryl chloride ( $0.2 \mathrm{mmol}, 1$ eq.), the aryl 
chloride (0.3 mmol, 1.5 eq.), Nil 2 (6.3 mg, 10 mol\%), 2,2'-bipyridine (4.7 mg, 15 mol\%), Zn (26.2 mg, 0.4 mmol, 2 eq.), and $\mathrm{MgCl}_{2}(38.1 \mathrm{mg}, 0.4 \mathrm{mmol}, 2$ eq.). The vial was sealed with a screw cap fitted with a PTFE-faced silicone septum, and then DMF ( $1 \mathrm{~mL}, 0.2 \mathrm{M}$ relative to the heteroaryl chloride) was added at room temperature under an atmosphere of argon. The argon balloon was removed and the vial was placed in an oil bath pre-heated to $85^{\circ} \mathrm{C}$ and stirred for $24 \mathrm{~h}$.

The reaction mixture was cooled to room temperature and filtered through a short plug of silica gel, eluting with ethyl acetate. The filtrate was then washed twice with water and twice with brine. The organic layer was then dried over $\mathrm{MgSO}_{4}$, and then filtered over a short plug of silica gel, eluting with ethyl acetate. The crude material was purified by flash column chromatography (conditions specified for each compound).

\section{General Procedure D - Procedure for Cross-Electrophile Coupling of Heteroaryl and Aryl Chlorides}

An oven-dried 2-dram vial was charged with a PTFE-coated stir bar and cooled under a positive pressure of argon. To the vial was added sequentially the heteroaryl chloride ( $0.2 \mathrm{mmol}, 1 \mathrm{eq}$ ) $) \mathrm{Nil}_{2}$ (6.3 $\mathrm{mg}, 10 \mathrm{~mol} \%$ ), 2,2'-bipyridine ( $4.7 \mathrm{mg}, 15 \mathrm{~mol} \%$ ), $\mathrm{Zn}$ (26.2 mg, $0.4 \mathrm{mmol}, 2$ eq.), and $\mathrm{MgCl}_{2}$ (38.1 mg, 0.4 mmol, 2 eq.). The vial was sealed with a screw cap fitted with a PTFE-faced silicone septum. The aryl chloride ( $0.3 \mathrm{mmol}, 1.5$ eq.) was dissolved in DMF ( $1 \mathrm{~mL}, 0.2 \mathrm{M}$ relative to the heteroaryl chloride) and was added to the 2-dram vial at room temperature under an atmosphere of argon. The argon balloon was removed and the vial was placed in an oil bath pre-heated to $85^{\circ} \mathrm{C}$ and stirred for $24 \mathrm{~h}$.

The reaction mixture was cooled to room temperature and filtered through a short plug of silica gel, eluting with ethyl acetate. The filtrate was then washed twice with water and twice with brine. The organic layer was then dried over $\mathrm{MgSO}_{4}$, and then filtered over a short plug of silica gel, eluting with ethyl acetate. The crude material was purified by flash column chromatography (conditions specified for each compound).

\section{General Procedure E - Procedure for Cross-Electrophile Coupling of Heteroaryl and Aryl Chlorides}

An oven-dried 2-dram vial was charged with a PTFE-coated stir bar and cooled under a positive pressure of argon. To the vial was added sequentially the aryl chloride $\left(0.3 \mathrm{mmol}, 1.5 \mathrm{eq}\right.$.), $\mathrm{Nil}_{2}(6.3 \mathrm{mg}$, 10 mol\%), 2,2'-bipyridine ( $4.7 \mathrm{mg}, 15 \mathrm{~mol} \%$ ), $\mathrm{Zn}$ (26.2 mg, $0.4 \mathrm{mmol}, 2$ eq.), and $\mathrm{MgCl}_{2}$ (38.1 mg, $0.4 \mathrm{mmol}$, 2 eq.). The vial was sealed with a screw cap fitted with a PTFE-faced silicone septum. The heteroaryl chloride $(0.2 \mathrm{mmol}, 1$ eq.) was dissolved in DMF ( $1 \mathrm{~mL}, 0.2 \mathrm{M}$ relative to the heteroaryl chloride) and was added to the 2-dram vial at room temperature under an atmosphere of argon. The argon balloon was removed and the vial was placed in an oil bath pre-heated to $85^{\circ} \mathrm{C}$ and stirred for $24 \mathrm{~h}$.

The reaction mixture was cooled to room temperature and filtered through a short plug of silica gel, eluting with ethyl acetate. The filtrate was then washed twice with water and twice with brine. The organic layer was then dried over $\mathrm{MgSO}_{4}$, and then filtered over a short plug of silica gel, eluting with ethyl acetate. The crude material was purified by flash column chromatography (conditions specified for each compound). 


\subsection{Methyl 4-(1-methyl-1H-benzo[d]imidazol-2-yl)benzoate, 3aa}

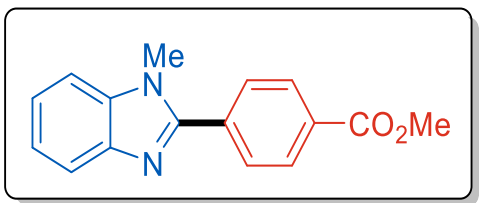

The title compound was synthesized according to General Procedure $\mathbf{C}$. The crude material was purified by flash column chromatography (gradient elution, $30 \% \rightarrow 50 \%$ EtOAc in pentane) to afford 3aa as a white solid $(47.8 \mathrm{mg}, 90 \%$ yield). The spectroscopic data matched those reported in the literature. ${ }^{13}$

${ }^{1} \mathrm{H}$ NMR $\left(\mathrm{CDCl}_{3}, 500 \mathrm{MHz}\right): \delta 8.21-8.13(\mathrm{~m}, 2 \mathrm{H}), 7.89-7.79(\mathrm{~m}, 3 \mathrm{H}), 7.40-7.34(\mathrm{~m}, 1 \mathrm{H}), 7.34-7.28(\mathrm{~m}$, $2 \mathrm{H}), 3.94(\mathrm{~s}, 3 \mathrm{H}), 3.85(\mathrm{~s}, 3 \mathrm{H})$.

${ }^{13} \mathrm{C}\left\{{ }^{1} \mathrm{H}\right\}$ NMR $\left(\mathrm{CDCl}_{3}, 125 \mathrm{MHz}\right): \delta$ 166.5, 152.5, 142.8, 136.7, 134.4, 131.2, 129.9, 129.5, 123.4, 122.8, 120.0, 109.9, 52.4, 31.9.

\subsection{Methyl 4-(1-benzyl-1H-benzo[d]imidazol-2-yl)benzoate, 3ba}

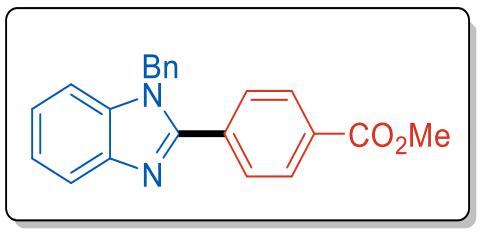

The title compound was synthesized according to General Procedure C. The crude material was purified by flash column chromatography (gradient elution, $30 \rightarrow 50 \%$ EtOAc in pentane) to afford 3 ba as a white solid (64.3 $\mathrm{mg}, 94 \%$ yield). The spectroscopic data matched those reported in the literature. ${ }^{14}$

${ }^{1} \mathrm{H}$ NMR $\left(\mathrm{CDCl}_{3}, 500 \mathrm{MHz}\right): \delta 8.15-8.03(\mathrm{~m}, 2 \mathrm{H}), 7.92-7.86(\mathrm{~m}, 1 \mathrm{H}), 7.80-7.73(\mathrm{~m}, 2 \mathrm{H}), 7.37-7.22(\mathrm{~m}$, $6 \mathrm{H}), 7.11-7.05(\mathrm{~m}, 2 \mathrm{H}), 5.46(\mathrm{~s}, 2 \mathrm{H}), 3.93(\mathrm{~s}, 3 \mathrm{H})$.

${ }^{13} \mathrm{C}\left\{{ }^{1} \mathrm{H}\right\}$ NMR $\left(\mathrm{CDCl}_{3}, 125 \mathrm{MHz}\right): \delta$ 166.5, 153.0, 143.2, 136.3, 136.2, 134.4, 131.3, 130.0, 129.3, 129.3, $128.0,126.0,123.6,123.1,120.3,110.7,52.4,48.5$.

\subsection{Methyl 4-(1H-benzo[d]imidazol-2-yl)benzoate, 3ca}

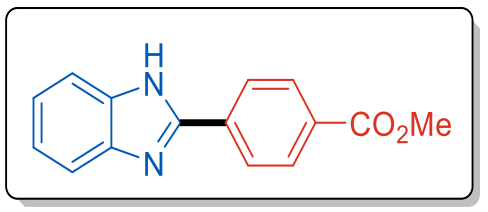

The title compound was synthesized according to General Procedure $\mathbf{C}$. The crude material was purified by flash column chromatography (gradient elution, $30 \rightarrow 50 \%$ EtOAc in pentane) to afford $3 \mathrm{ca}$ as a white solid (27.2 $\mathrm{mg}, 54 \%$ yield). The spectroscopic data matched those reported in the literature. ${ }^{15}$

${ }^{1}$ H NMR (DMSO-d 6,500 MHz): $\delta 13.18(\mathrm{~s}, 1 \mathrm{H}), 8.38-8.28(\mathrm{~m}, 2 \mathrm{H}), 8.18-8.09(\mathrm{~m}, 2 \mathrm{H}), 7.63(\mathrm{~s}, 2 \mathrm{H}), 7.29$ $-7.13(\mathrm{~m}, 2 \mathrm{H}), 3.89(\mathrm{~s}, 3 \mathrm{H})$.

${ }^{13} \mathrm{C}\left\{{ }^{1} \mathrm{H}\right\}$ NMR (DMSO-d $\left.\mathrm{d}_{6}, 125 \mathrm{MHz}\right): \delta$ 165.8, 150.0, 138.6, 134.3, 130.3, 129.8, 126.6, 122.6, 122.0, 118.3, 111.0, 52.3. 


\subsection{Methyl 4-(1-(2-fluorobenzyl)-1H-benzo[d]imidazol-2-yl)benzoate, 3da}

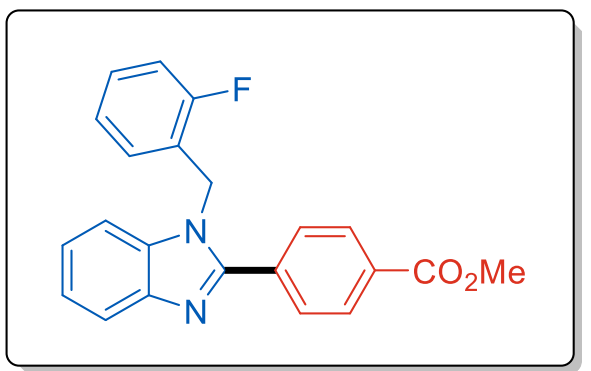

The title compound was synthesized according to General Procedure $\mathbf{C}$. The crude material was purified by flash column chromatography (50\% EtOAc in pentane) to afford $3 \mathrm{da}$ as a white solid (36.7 $\mathrm{mg}, 51 \%$ yield).

${ }^{1} \mathrm{H} \mathrm{NMR}\left(\mathrm{CDCl}_{3}, 500 \mathrm{MHz}\right): \delta 8.18-8.06(\mathrm{~m}, 2 \mathrm{H}), 7.91(\mathrm{~d}, J=8.0$ $\mathrm{Hz}, 1 \mathrm{H}), 7.81-7.73(\mathrm{~m}, 2 \mathrm{H}), 7.36(\mathrm{ddd}, J=8.1,6.7,1.6 \mathrm{~Hz}, 1 \mathrm{H})$, $7.34-7.27$ (m, 3H), 7.13 (ddd, $J=10.3,8.3,1.2 \mathrm{~Hz}, 1 \mathrm{H}$ ), 7.03 (td, $J=7.6,1.1 \mathrm{~Hz}, 1 \mathrm{H}), 6.80$ (td, $J=7.7,1.7$ $\mathrm{Hz}, 1 \mathrm{H}), 5.52(\mathrm{~s}, 2 \mathrm{H}), 3.94(\mathrm{~s}, 3 \mathrm{H})$.

${ }^{13} \mathrm{C}\left\{{ }^{1} \mathrm{H}\right\}$ NMR $\left(\mathrm{CDCl}_{3}, 125 \mathrm{MHz}\right): \delta 160.0(\mathrm{~d}, J=246.8 \mathrm{~Hz}), 152.9,136.0,133.9,131.6,130.2,130.0(\mathrm{~d}, J=$ $8.1 \mathrm{~Hz}$ ), 129.4, 127.6 (d, J = 3.5 Hz), 124.9 (d, J = 3.6 Hz), 124.0, 123.5, 123.2 (d, J = $14.1 \mathrm{~Hz}$ ), 120.3, 115.9 (d, $J=20.6 \mathrm{~Hz}), 110.6,52.5,42.9(\mathrm{~d}, J=5.5 \mathrm{~Hz}$ ).

${ }^{19} \mathrm{~F} \mathrm{NMR}\left(\mathrm{CDCl}_{3}, 377 \mathrm{MHz}\right): \delta-117.8$

IR (neat, $\mathrm{cm}^{-1}$ ): 3056, 2956, 1722, 1613, 1495, 1438, 1416,1371, 1310, 1259, 1171, 1096, 854, 760, 714

Mass: DART, calc for $\mathrm{C}_{22} \mathrm{H}_{18} \mathrm{FN}_{2} \mathrm{O}_{2} 361.13468[\mathrm{M}+\mathrm{H}]^{+}$, found 361.13460 .

Melting point: $169-171^{\circ} \mathrm{C}$

\subsection{Methyl 4-(benzo[d]oxazol-2-yl)benzoate, 3ea}

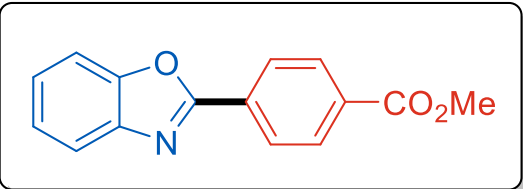

The title compound was synthesized according to General Procedure E. The crude material was purified by flash column chromatography (12:8:1 pentane:DCM:EtOAC) to afford 3ea as a white solid (35.5 mg, 70\% yield). The spectroscopic data matched those reported in the literature. ${ }^{16}$

${ }^{1} \mathrm{H}$ NMR (CDCl, $\left.500 \mathrm{MHz}\right): \delta 8.36-8.27(\mathrm{~m}, 1 \mathrm{H}), 8.21-8.10(\mathrm{~m}, 1 \mathrm{H}), 7.82-7.76(\mathrm{~m}, 1 \mathrm{H}), 7.65-7.56(\mathrm{~m}$, $1 \mathrm{H}), 7.46-7.32(\mathrm{~m}, 1 \mathrm{H}), 3.96(\mathrm{~s}, 2 \mathrm{H})$.

${ }^{13} \mathrm{C}\left\{{ }^{1} \mathrm{H}\right\}$ NMR (CDCl $\left.3,125 \mathrm{MHz}\right): \delta$ 166.5, 162.1, 151.0, 142.1, 132.7, 131.2, 130.2, 127.6, 125.9, 125.0, $120.5,110.9,52.5$. 
3.8 Methyl 4-(2-(3-methoxy-3-oxopropyl)-3-methyl-4-oxo-3,4-dihydroquinazolin-6-yl)benzoate, 3fa

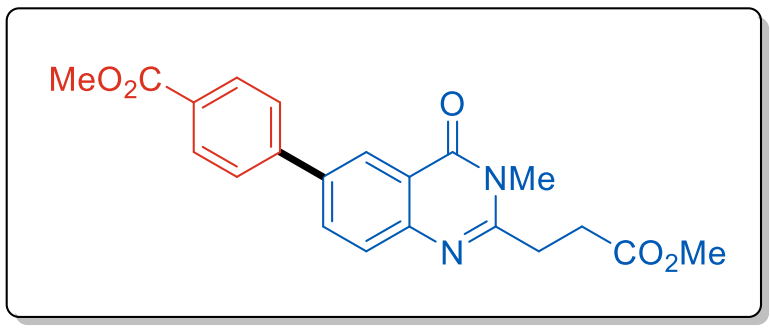

The title compound was synthesized according to General Procedure B. The crude material was purified by flash column chromatography $(10 \%$ acetone in DCM) to afford $3 \mathrm{fa}$ as a white solid (41.8 $\mathrm{mg}, 55 \%$ yield).

${ }^{1} \mathrm{H}$ NMR $\left(\mathrm{CDCl}_{3}, 500 \mathrm{MHz}\right): \delta 8.51(\mathrm{~d}, J=2.3 \mathrm{~Hz}, 1 \mathrm{H})$, $8.15-8.10(\mathrm{~m}, 2 \mathrm{H}), 7.97(\mathrm{dd}, J=8.5,2.3 \mathrm{~Hz}, 1 \mathrm{H}), 7.77-7.72(\mathrm{~m}, 2 \mathrm{H}), 7.67(\mathrm{~d}, J=8.5 \mathrm{~Hz}, 1 \mathrm{H}), 3.95(\mathrm{~s}, 3 \mathrm{H})$, $3.74(\mathrm{~s}, 3 \mathrm{H}), 3.67(\mathrm{~s}, 3 \mathrm{H}), 3.15(\mathrm{t}, J=6.7 \mathrm{~Hz}, 2 \mathrm{H}), 2.98(\mathrm{t}, J=6.7 \mathrm{~Hz}, 2 \mathrm{H})$.

${ }^{13} \mathrm{C}\left\{{ }^{1} \mathrm{H}\right\}$ NMR $\left(\mathrm{CDCl}_{3}, 125 \mathrm{MHz}\right): \delta$ 173.4, 167.0, 162.5, 155.3, 146.9, 144.2, 138.2, 133.0, 130.4, 129.4, $127.9,127.2,125.3,120.7,52.3,52.1,30.3,30.2,29.8$.

IR (neat, cm $^{-1}$ ): 2956, 2929, 2865, 1728, 1713, 1665, 1595, 1483, 1434, 1338, 1271, 1186, 1108, 830, 775

Mass: DART, calc for $\mathrm{C}_{21} \mathrm{H}_{21} \mathrm{~N}_{2} \mathrm{O}_{5} 381.14450[\mathrm{M}+\mathrm{H}]^{+}$, found 381.14435

Melting point: $151-153^{\circ} \mathrm{C}$

\subsection{Methyl 4-(pyridin-3-yl)benzoate, 3ga}

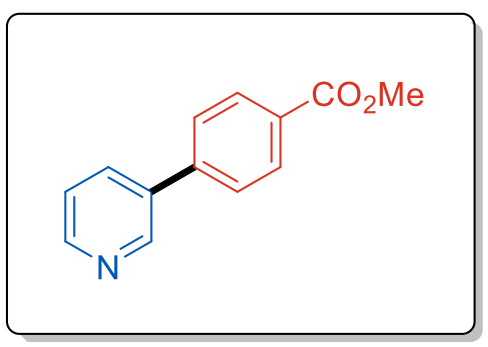

The title compound was synthesized according to General Procedure E. The crude material was purified by flash column chromatography (gradient elution, $30 \rightarrow 40 \%$ EtOAc in pentane) to afford 3ga as a white solid $(23.2 \mathrm{mg}, 54 \%$ yield). The spectroscopic data matched those reported in the literature. ${ }^{17}$

${ }^{1} \mathrm{H}$ NMR $\left(\mathrm{CDCl}_{3}, 500 \mathrm{MHz}\right): \delta 8.88(\mathrm{~s}, 1 \mathrm{H}), 8.63(\mathrm{~s}, 1 \mathrm{H}), 8.18-8.07(\mathrm{~m}$, 2H), $7.89(\mathrm{dt}, J=8.0,1.9 \mathrm{~Hz}, 1 \mathrm{H}), 7.68-7.59(\mathrm{~m}, 2 \mathrm{H}), 7.38(\mathrm{dd}, J=8.0,4.7 \mathrm{~Hz}, 1 \mathrm{H}), 3.93(\mathrm{~s}, 3 \mathrm{H})$.

${ }^{13} \mathrm{C}\left\{{ }^{1} \mathrm{H}\right\}$ NMR $\left(\mathrm{CDCl}_{3}, 125 \mathrm{MHz}\right): \delta 166.8,149.3,148.4,142.3,134.6,130.4,129.9,127.2,123.8,52.3$. 


\subsection{Methyl 4-(pyridin-2-yl)benzoate, 3ha}

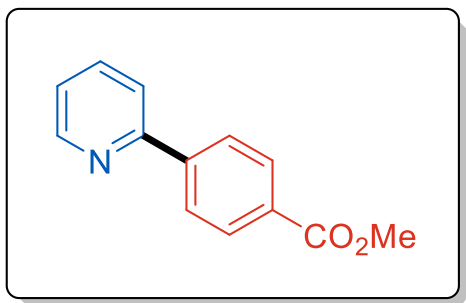

The title compound was synthesized according to General Procedure E. The crude material was purified by flash column chromatography $(10 \%$ EtOAc in DCM) to afford 3ha as a white solid ( $36.3 \mathrm{mg}, 85 \%$ yield). The spectroscopic data matches those reported in the literature. ${ }^{18}$

${ }^{1} \mathrm{H}$ NMR $\left(\mathrm{CDCl}_{3}, 500 \mathrm{MHz}\right): \delta 8.72(\mathrm{dt}, J=4.8,1.4 \mathrm{~Hz}, 1 \mathrm{H}), 8.17-8.10(\mathrm{~m}$, $2 \mathrm{H}), 8.10-8.02(\mathrm{~m}, 2 \mathrm{H}), 7.80-7.71(\mathrm{~m}, 2 \mathrm{H}), 7.35-7.14(\mathrm{~m}, 1 \mathrm{H}), 3.93(\mathrm{~s}$, $3 \mathrm{H})$.

${ }^{13} \mathrm{C}\left\{{ }^{1} \mathrm{H}\right\}$ NMR $\left(\mathrm{CDCl}_{3}, 125 \mathrm{MHz}\right): \delta$ 167.0, 156.2, 149.9, 143.5, 137.1, 130.5, 130.2, 127.0, 123.0, 121.2, 52.3.

\subsection{Methyl 4-(5,6-difluoropyridin-3-yl)benzoate, 3ia}

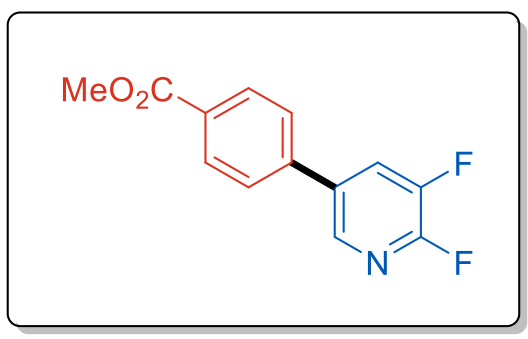

$3 \mathrm{H})$.
The title compound was synthesized according to General Procedure E. The crude material was purified by flash column chromatography (gradient elution, $7 \rightarrow 10 \rightarrow 12 \%$ EtOAc in pentane) to afford 3ia as a white solid ( $27.3 \mathrm{mg}, 55 \%$ yield).

${ }^{1} \mathrm{H}$ NMR $\left(\mathrm{CDCl}_{3}, 500 \mathrm{MHz}\right): \delta 8.23(\mathrm{t}, J=1.9 \mathrm{~Hz}, 1 \mathrm{H}), 8.18-8.13(\mathrm{~m}$, 2H), 7.79 (ddd, $J=9.8,8.8,2.1 \mathrm{~Hz}, 1 \mathrm{H}), 7.63-7.59(\mathrm{~m}, 2 \mathrm{H}), 3.96(\mathrm{~s}$,

${ }^{13} \mathrm{C}\left\{{ }^{1} \mathrm{H}\right\}$ NMR (CDCl $\left.3,125 \mathrm{MHz}\right): \delta$ 166.6, $145.6(\mathrm{dd}, J=262.3,28.3 \mathrm{~Hz}), 140.1$ - $139.8(\mathrm{~m}), 130.7,130.5$, $127.4,127.2,125.5(\mathrm{~d}, J=3.6 \mathrm{~Hz}), 125.4(\mathrm{~d}, J=3.4 \mathrm{~Hz}$ ), 52.5. (Note: the carbon peak adjacent to the pyridine nitrogen substituted with a fluorine atom could not be located, presumably due to C-F J coupling and lack of NOE)

${ }^{19} \mathrm{~F} \mathrm{NMR}\left(\mathrm{CDCl}_{3}, 377 \mathrm{MHz}\right): \delta-88.0,-139.3$

IR (neat, cm $^{-1}$ ): 2946, 1717, 1605, 1485, 1426, 1394, 1272, 1188, 1156, 1097, 859, 827, 757

Mass: DART, calc for $\mathrm{C}_{13} \mathrm{H}_{10} \mathrm{~F}_{2} \mathrm{NO}_{2} 250.06741[\mathrm{M}+\mathrm{H}]^{+}$, found 250.06892 .

Melting point: $166-168^{\circ} \mathrm{C}$ 


\subsection{Methyl 4-(2-butyl-5-formyl-1-methyl-1H-imidazol-4-yl)benzoate, 3ja}

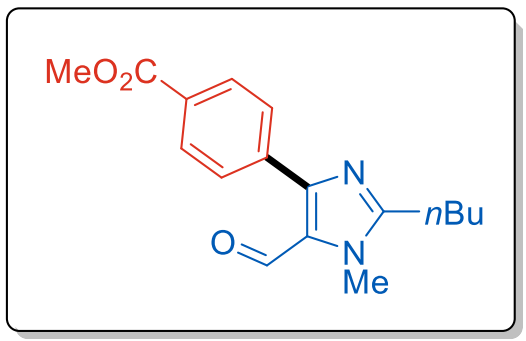

The title compound was prepared according to General Procedure E. The crude material was purified by flash column chromatography (50\% EtOAc in pentane) to afford $\mathbf{3}$ ja as a yellow sap $(31.1 \mathrm{mg}, 52 \%$ yield).

${ }^{1} \mathrm{H} \mathrm{NMR}\left(\mathrm{CDCl}_{3}, 500 \mathrm{MHz}\right): \delta 9.81(\mathrm{~d}, J=0.9 \mathrm{~Hz}, 1 \mathrm{H}), 8.16-8.07(\mathrm{~m}$, $2 \mathrm{H}), 7.77-7.65(\mathrm{~m}, 2 \mathrm{H}), 3.94(\mathrm{~d}, J=1.1 \mathrm{~Hz}, 4 \mathrm{H}), 3.94(\mathrm{~d}, J=0.9 \mathrm{~Hz}$, $3 \mathrm{H}), 2.84-2.75(\mathrm{~m}, 2 \mathrm{H}), 1.83-1.72(\mathrm{~m}, 1 \mathrm{H}), 1.46(\mathrm{dt}, J=14.7,7.2 \mathrm{~Hz}, 1 \mathrm{H}), 0.97(\mathrm{td}, J=7.4,0.8 \mathrm{~Hz}, 3 \mathrm{H})$.

${ }^{13} \mathrm{C}\left\{{ }^{1} \mathrm{H}\right\}$ NMR $\left(\mathrm{CDCl}_{3}, 125 \mathrm{MHz}\right): \delta 180.5,166.8,155.2,130.6,130.0,129.3,127.5,52.4,32.9,29.7,26.7$, 22.7, 13.9.

IR (neat, cm$^{-1}$ ): 2956, 2932, 2856, 2902, 1716, 1707, 1652, 1616, 1474, 1441, 1365, 1326, 1274, 1186, $1105,999,866,826$

Mass: DART, calc for $\mathrm{C}_{17} \mathrm{H}_{21} \mathrm{~N}_{2} \mathrm{O}_{3} 301.15467[\mathrm{M}+\mathrm{H}]^{+}$, found 301.15449 .

\subsection{Methyl 4-(9-methyl-9H-purin-6-yl)benzoate, 3ka}

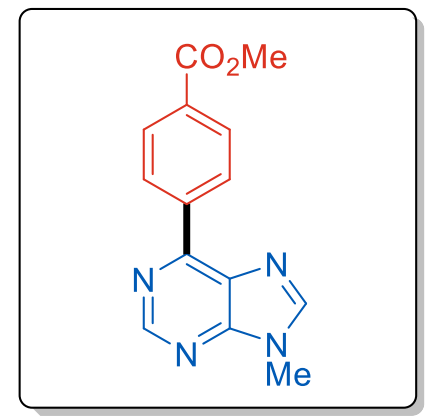

The title compound was prepared according to General Procedure $\mathbf{C}$. The crude material was purified by flash column chromatography ( $5 \% \mathrm{MeOH}$ in DCM) to afford $3 k$ a as a white solid (16.1 $\mathrm{mg}, 30 \%$ yield).

${ }^{1}$ H NMR (DMSO-d $\left.d_{6}, 500 \mathrm{MHz}\right): \delta 9.04(\mathrm{~s}, 1 \mathrm{H}), 8.99-8.94(\mathrm{~m}, 2 \mathrm{H}), 8.69(\mathrm{~s}$, $1 \mathrm{H}), 8.18-8.14(\mathrm{~m}, 2 \mathrm{H}), 3.91(\mathrm{~s}, 4 \mathrm{H}), 3.89(\mathrm{~s}, 3 \mathrm{H})$.

${ }^{13} \mathrm{C}\left\{{ }^{1} \mathrm{H}\right\}$ NMR (DMSO-d $\left.\boldsymbol{d}_{6}, 125 \mathrm{MHz}\right): \delta$ 165.9, 153.1, 151.7, 150.8, 147.8, $139.7,131.3,130.6,129.5,129.4,52.3,29.7$.

IR (neat, cm ${ }^{-1}$ ): 2926, 2859, 1713, 1583, 1565, 1501, 1441, 1395, 1285, 1241, 1102, 926

Mass: DART, calc for $\mathrm{C}_{14} \mathrm{H}_{13} \mathrm{~N}_{4} \mathrm{O}_{2} 269.10330[\mathrm{M}+\mathrm{H}]^{+}$, found 269.10332 .

Melting point: $180-182^{\circ} \mathrm{C}$ 


\subsection{Methyl 4-(7-methyl-7H-pyrrolo[2,3-d]pyrimidin-4-yl)benzoate, 3la}

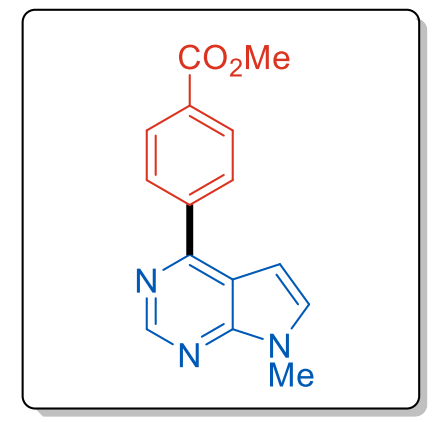

The title compound was prepared according to General Procedure C. The crude material was purified by flash column chromatography ( $7 \% \mathrm{MeOH}$ in DCM) to afford 3la as a white solid ( $7.5 \mathrm{mg}, 14 \%$ yield).

${ }^{1} \mathrm{H}$ NMR (DMSO- $\boldsymbol{d}_{6}, 500 \mathrm{MHz}$ ): $\delta 8.91(\mathrm{~s}, 1 \mathrm{H}), 8.34-8.23(\mathrm{~m}, 2 \mathrm{H}), 8.19-8.05$ $(\mathrm{m}, 2 \mathrm{H}), 7.74(\mathrm{~d}, J=3.6 \mathrm{~Hz}, 1 \mathrm{H}), 6.94(\mathrm{~d}, J=3.6 \mathrm{~Hz}, 1 \mathrm{H}), 3.90(\mathrm{~s}, 3 \mathrm{H}), 3.87(\mathrm{~s}$, $3 \mathrm{H})$.

${ }^{13} \mathrm{C}\left\{{ }^{1} \mathrm{H}\right\}$ NMR (DMSO- $\left.d_{6}, 125 \mathrm{MHz}\right): \delta 165.9,154.1,151.6,150.8,141.9,132.3,130.6,129.6,128.8,115.0$, $99.2,52.3,31.0$.

IR (neat, cm$^{-1}$ ): 2926, 1622, 1495, 1453, 1401, 1053, 1032, 1005, 823, 754

Mass: DART, calc for $\mathrm{C}_{15} \mathrm{H}_{14} \mathrm{~N}_{3} \mathrm{O}_{2} 268.10805[\mathrm{M}+\mathrm{H}]^{+}$, found 268.10754 .

Melting point: $133-135^{\circ} \mathrm{C}$

\subsection{1-benzyl-2-(4-(trifluoromethyl)phenyl)-1H-benzo[d]imidazole, 3ma}

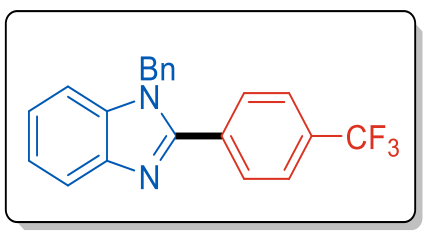

The title compound was synthesized according to General Procedure B. The crude material was purified by flash column chromatography (gradient elution, $15 \rightarrow 25 \%$ EtOAc in pentane) to afford $3 \mathrm{ma}$ as a white solid (54.2 $\mathrm{mg}, 77 \%$ yield). The spectroscopic data matched those reported in the literature. ${ }^{19}$

${ }^{1}{ }_{\mathrm{H}} \mathrm{NMR}\left(\mathrm{CDCl}_{3}, 500 \mathrm{MHz}\right): \delta 7.90(\mathrm{~d}, J=8.1 \mathrm{~Hz}, 1 \mathrm{H}), 7.82(\mathrm{~d}, J=8.1 \mathrm{~Hz}, 2 \mathrm{H}), 7.71(\mathrm{~d}, J=8.1 \mathrm{~Hz}, 2 \mathrm{H}), 7.41-$ $7.23(\mathrm{~m}, 6 \mathrm{H}), 7.12-7.07(\mathrm{~m}, 2 \mathrm{H}), 5.46(\mathrm{~s}, 3 \mathrm{H})$.

${ }^{13} \mathrm{C}\left\{{ }^{1} \mathrm{H}\right\}$ NMR (CDCl, $\left.125 \mathrm{MHz}\right): \delta 152.5,143.0,136.3,136.1,133.6,131.9$ (q, $\left.J=32.7 \mathrm{~Hz}\right), 129.7,129.3$, $128.1,125.9,125.8$ (q, $J=3.8 \mathrm{~Hz}), 123.9(1, J=273.0 \mathrm{~Hz}), 123.8,123.2$, 120.3, 110.7, 48.5.

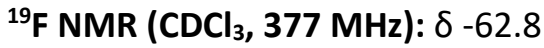

\subsection{N-Cyclopropyl-4-(1-methyl-1H-benzo[d]imidazol-2-yl)benzenesulfonamide, 3na}

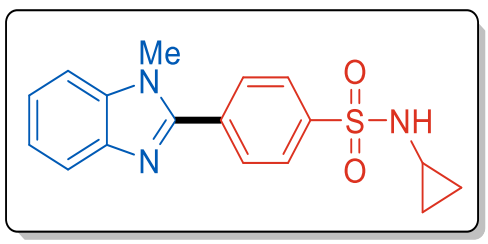

The title compound was synthesized according to General Procedure B. The crude material was purified by flash column chromatography (gradient elution, $50 \rightarrow 60 \rightarrow 70 \%$ EtOAc in pentane) to afford $\mathbf{3 d}$ as a white solid (44.6 $\mathrm{mg}, 68 \%$ yield). 
${ }^{1} \mathrm{H}$ NMR (DMSO- $\left.\boldsymbol{d}_{6}, 500 \mathrm{MHz}\right): \delta 8.17-8.08(\mathrm{~m}, 3 \mathrm{H}), 8.00(\mathrm{~d}, J=8.5 \mathrm{~Hz}, 2 \mathrm{H}$ ), $7.72(\mathrm{~d}, J=7.8 \mathrm{~Hz}, 1 \mathrm{H}), 7.66$ $(\mathrm{d}, J=8.0 \mathrm{~Hz}, 1 \mathrm{H}$ ), 7.33 (ddd, $J=8.2,7.2,1.2 \mathrm{~Hz}, 1 \mathrm{H}$ ), 7.28 (ddd, $J=8.3,7.1,1.2 \mathrm{~Hz}, 1 \mathrm{H}$ ), $3.93(\mathrm{~s}, 3 \mathrm{H}), 2.19$ (tq, $J=6.6,3.3 \mathrm{~Hz}, 1 \mathrm{H}), 0.53(\mathrm{td}, J=7.1,4.8 \mathrm{~Hz}, 2 \mathrm{H}), 0.47-0.41(\mathrm{~m}, 2 \mathrm{H})$

${ }^{13} \mathrm{C}\left\{{ }^{1} \mathrm{H}\right\}$ NMR (DMSO- $\left.d_{6}, 125 \mathrm{MHz}\right): \delta$ 151.5, 142.4, 141.0, 136.7, 133.8, 130.0, 127.1, 122.9, 122.2, 119.3, $110.8,31.8,24.2,5.2$

IR (neat, cm cm $^{-1}$ : 3020, 2932, 2865, 1613, 1459, 1410, 1368, 1332, 1150, 1047, 829, 754

Mass: DART, calc for $\mathrm{C}_{17} \mathrm{H}_{18} \mathrm{~N}_{3} \mathrm{O}_{2} \mathrm{~S} 328.11142[\mathrm{M}+\mathrm{H}]^{+}$, found 328.11153 .

Melting point: $206-208^{\circ} \mathrm{C}$

\subsection{4-(1-methyl-1H-benzo[d]imidazol-2-yl)benzenesulfonamide, 3oa}

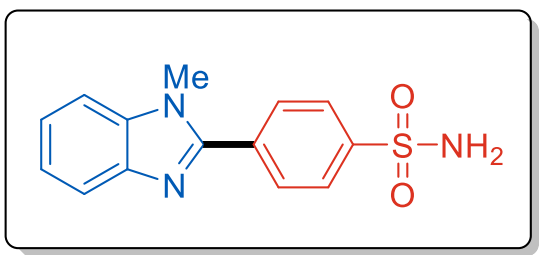

The title compound was prepared according to General Procedure C. The crude material was purified by flash column chromatography (4\% $\mathrm{MeOH}$ in DCM) to afford 3oa as a white solid $(24.2 \mathrm{mg}, 42 \%$ yield). The spectroscopic data matched those reported in the literature. ${ }^{20}$

${ }^{1}$ H NMR (DMSO- $\left.\boldsymbol{d}_{6}, 500 \mathrm{MHz}\right): \delta 8.11-8.05(\mathrm{~m}, 1 \mathrm{H}), 8.05-7.98(\mathrm{~m}$, 1H), $7.72(\mathrm{~d}, J=7.9 \mathrm{~Hz}, \mathrm{OH}), 7.66(\mathrm{~d}, J=8.0 \mathrm{~Hz}, \mathrm{OH}), 7.54(\mathrm{~s}, 1 \mathrm{H}), 7.33$ (ddd, $J=8.2,7.1,1.2 \mathrm{~Hz}, 1 \mathrm{H}), 7.28$ (ddd, $J=8.2,7.1,1.2 \mathrm{~Hz}, 1 \mathrm{H}), 3.92(\mathrm{~s}, 1 \mathrm{H})$.

${ }^{13} \mathrm{C}\left\{{ }^{1} \mathrm{H}\right\}$ NMR (DMSO- $\left.\boldsymbol{d}_{6}, 125 \mathrm{MHz}\right): \delta$ 151.6, 144.8, 142.4, 136.7, 133.2, 129.8, 125.9, 122.8, 122.2, 119.2, $110.8,31.8$.

\subsection{1-((4-(1-methyl-1H-benzo[d]imidazol-2-yl)phenyl)sulfonyl)-1,2,3,4-tetrahydroquinoline, 3pa}

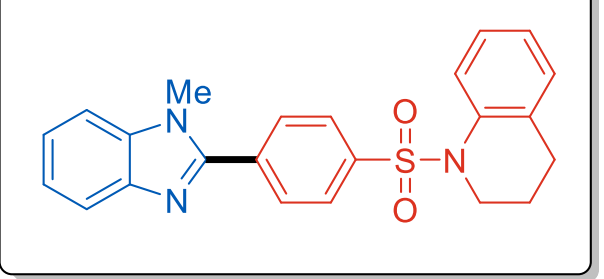

The title compound was prepared according to General Procedure $\mathbf{C}$. The crude material was purified by flash column chromatography (50\% EtOAc in pentane) to afford 3 pa as a white solid (39.3 $\mathrm{mg}, 49 \%$ yield).

${ }^{1} \mathrm{H}$ NMR (DMSO- $\left.d_{6}, 500 \mathrm{MHz}\right): \delta 8.08-8.01(\mathrm{~m}, 2 \mathrm{H}), 7.80-7.74$ $(\mathrm{m}, 2 \mathrm{H}), 7.69(\mathrm{dt}, J=7.9,1.0 \mathrm{~Hz}, 1 \mathrm{H}), 7.68-7.61(\mathrm{~m}, 2 \mathrm{H}), 7.33$

(ddd, $J=8.2,7.1,1.2 \mathrm{~Hz}, 1 \mathrm{H}$ ), 7.27 (ddd, $J=8.2,7.1,1.2 \mathrm{~Hz}, 1 \mathrm{H}), 7.25-7.19(\mathrm{~m}, 1 \mathrm{H}), 7.13-7.05(\mathrm{~m}, 2 \mathrm{H})$, $3.88(\mathrm{~s}, 3 \mathrm{H}), 3.86-3.80(\mathrm{~m}, 2 \mathrm{H}), 2.47(\mathrm{t}, J=6.7 \mathrm{~Hz}, 2 \mathrm{H}), 1.71-1.60(\mathrm{~m}, 2 \mathrm{H})$.

${ }^{13} \mathrm{C}\left\{{ }^{1} \mathrm{H}\right\}$ NMR (DMSO- $\left.d_{6}, 125 \mathrm{MHz}\right): \delta$ 151.1, 142.4, 139.6, 136.7, 136.2, 134.5, 130.7, 130.1, 129.4, 127.0, $126.3,125.0,123.8,123.0,122.3,119.3,110.8,46.3,31.8,25.9,21.2$.

IR (neat, cm cm $^{-1}$ : 3071, 2938, 2865, 1740, 1601, 1489, 1469, 1407, 1338, 1162, 1081, 842 
Mass: DART, calc for $\mathrm{C}_{15} \mathrm{H}_{15} \mathrm{CINO}_{2} \mathrm{~S} 308.05065[\mathrm{M}+\mathrm{H}]^{+}$, found 308.05038 .

Melting point: $166-168^{\circ} \mathrm{C}$

3.19 Ethyl 3-(1-methyl-1H-benzo[d]imidazol-2-yl)benzoate, 3qa

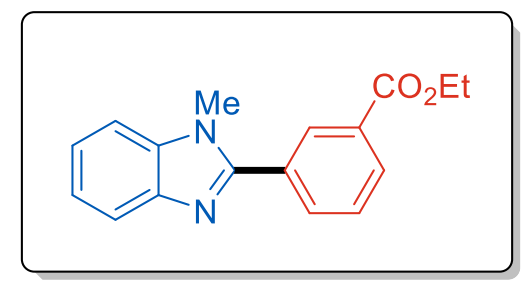

The title compound was prepared according to General Procedure $\mathbf{C}$. The crude material was purified by flash column chromatography (50\% EtOAc in pentane) to afford 3qa as a clear oil $(52.6 \mathrm{mg}, 94 \%$ yield).

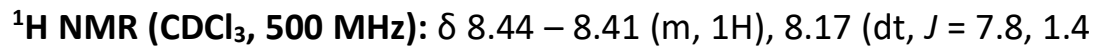
$\mathrm{Hz}, 1 \mathrm{H}), 7.97(\mathrm{ddd}, J=7.7,1.8,1.4 \mathrm{~Hz}, 1 \mathrm{H}), 7.85-7.80(\mathrm{~m}, 1 \mathrm{H}), 7.59(\mathrm{t}, J=7.8 \mathrm{~Hz}, 1 \mathrm{H}), 7.40-7.35(\mathrm{~m}, 1 \mathrm{H})$, $7.35-7.28(\mathrm{~m}, 2 \mathrm{H}), 4.40(\mathrm{q}, J=7.1 \mathrm{~Hz}, 2 \mathrm{H}), 3.85(\mathrm{~s}, 3 \mathrm{H}), 1.39(\mathrm{t}, J=7.1 \mathrm{~Hz}, 3 \mathrm{H})$.

${ }^{13} \mathrm{C}\left\{{ }^{1} \mathrm{H}\right\}$ NMR (CDCl, $\left.125 \mathrm{MHz}\right): \delta$ 166.0, 152.7, 142.9, 136.6, 133.8, 131.1, 130.8, 130.6, 130.3, 129.0, $123.1,122.7,120.0,109.8,61.4,31.8,14.4$.

IR (neat, cm ${ }^{-1}$ ): 2941, 1719, 1622, 1595, 1462, 1438, 1383, 1277, 1247, 1202, 1111, 1090, 1056, 823, 742

Mass: DART, calc for $\mathrm{C}_{17} \mathrm{H}_{17} \mathrm{~N}_{2} \mathrm{O}_{2} 281.12845[\mathrm{M}+\mathrm{H}]^{+}$, found 281.12833 .

\subsection{1-(2-fluorobenzyl)-2-(4-(trifluoromethyl)phenyl)-1H-benzo[d]imidazole, 3ra}

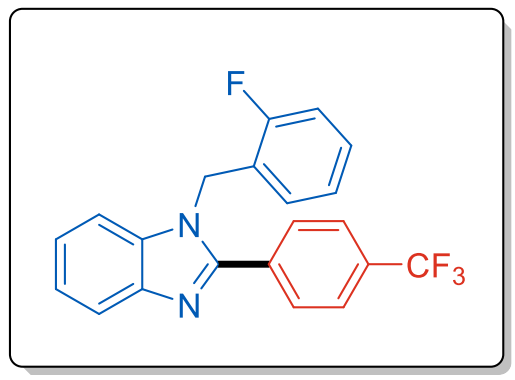

The title compound was prepared according to General Procedure C. The crude material was purified by flash column chromatography (30\% EtOAc in pentane) to afford 3ra as a white solid $(43.6 \mathrm{mg}, 59 \%$ yield).

${ }^{1} \mathrm{H}$ NMR $\left(\mathrm{CDCl}_{3}, 500 \mathrm{MHz}\right): \delta 7.91(\mathrm{dt}, J=8.1,0.9 \mathrm{~Hz}, 1 \mathrm{H}), 7.82(\mathrm{~d}, J=$ $8.1 \mathrm{~Hz}, 2 \mathrm{H}), 7.74(\mathrm{~d}, J=8.1 \mathrm{~Hz}, 2 \mathrm{H}), 7.37$ (ddd, $J=8.2,6.9,1.4 \mathrm{~Hz}, 1 \mathrm{H}$ ), $7.35-7.26(\mathrm{~m}, 3 \mathrm{H}), 7.14$ (ddd, $J=9.7,8.3,1.2 \mathrm{~Hz}, 1 \mathrm{H}), 7.05$ (td, $J=7.5$, $1.2 \mathrm{~Hz}, 1 \mathrm{H}), 6.81(\mathrm{td}, J=7.7,1.7 \mathrm{~Hz}, 1 \mathrm{H}), 5.51(\mathrm{~s}, 2 \mathrm{H})$.

${ }^{13} \mathrm{C}\left\{{ }^{1} \mathrm{H}\right\}$ NMR $\left(\mathrm{CDCl}_{3}, 125 \mathrm{MHz}\right): \delta 160.0(\mathrm{~d}, J=246.9 \mathrm{~Hz}), 152.5,142.8,136.0,133.3,132.1(\mathrm{~d}, J=32.7 \mathrm{~Hz})$, $130.0(\mathrm{~d}, J=8.1 \mathrm{~Hz}), 129.7,127.6(\mathrm{~d}, J=3.5 \mathrm{~Hz}), 126.0$ (q, J = 3.7 Hz), 125.0 (d, J = 3.6 Hz), 124.0, 123.9 (1, $J=273.9), 123.5,123.2(\mathrm{~d}, J=14.2 \mathrm{~Hz}), 120.4,115.9$ (d, $J=20.6 \mathrm{~Hz}), 110.6,42.9$ (d, J = 5.5 Hz).

${ }^{19} \mathrm{~F} \mathrm{NMR}\left(\mathrm{CDCl}_{3}, 377 \mathrm{MHz}\right): \delta-62.9,-117.8$

IR (neat, cm ${ }^{-1}$ ): 2944, 2859, 1622, 1489, 1459, 1416, 1383, 1329, 1232, 1165, 1117, 1065, 845 
Mass: DART, calc for $\mathrm{C}_{21} \mathrm{H}_{15} \mathrm{~F}_{4} \mathrm{~N}_{2} 371.11659[\mathrm{M}+\mathrm{H}]^{+}$, found 371.11685 .

Melting point: $137-139{ }^{\circ} \mathrm{C}$

3.21 1-methyl-2-phenyl-1H-benzo[d]imidazole, 3sa

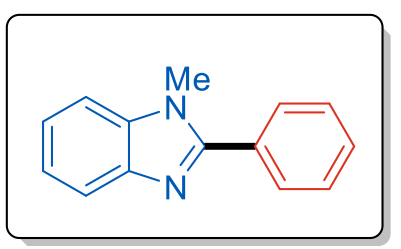

The title compound was synthesized according to General Procedure D. The crude material was purified by flash column chromatography ( $40 \%$ EtOAc in pentane) to afford 3sa as a white solid ( $21.9 \mathrm{mg}$, 53\% yield). The spectroscopic data matched those reported in the literature. ${ }^{21}$

${ }^{1} \mathrm{H}$ NMR $\left(\mathrm{CDCl}_{3}, 500 \mathrm{MHz}\right): \delta 7.86-7.80(\mathrm{~m}, 1 \mathrm{H}), 7.78-7.73(\mathrm{~m}, 2 \mathrm{H}), 7.55-$ $7.47(m, 3 H), 7.41-7.36(m, 1 H), 7.34-7.29(m, 2 H), 3.84(s, 3 H)$.

${ }^{13} \mathrm{C}\left\{{ }^{1} \mathrm{H}\right\}$ NMR $\left(\mathrm{CDCl}_{3}, 125 \mathrm{MHz}\right): \delta$ 153.8, 143.0, 136.6, 130.3, 129.8, 129.5, 128.8, 122.9, 122.5, 119.9, 109.7, 31.7.

\subsection{1-methyl-2-(p-tolyl)-1H-benzo[d]imidazole, 3ta}

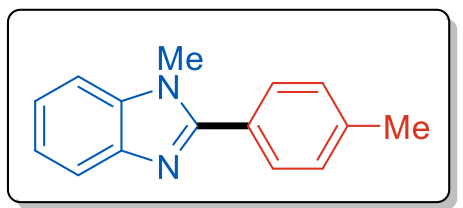

The title compound was synthesized according to General Procedure D. The crude material was purified by flash column chromatography $(30 \%$ EtOAc in pentane) to afford 3ta as a white solid ( $25.2 \mathrm{mg}, 57 \%$ yield). The spectroscopic data matched those reported in the literature. ${ }^{22}$

${ }^{1} \mathrm{H}$ NMR $\left(\mathrm{CDCl}_{3}, 500 \mathrm{MHz}\right): \delta 7.85-7.78(\mathrm{~m}, 1 \mathrm{H}), 7.69-7.62(\mathrm{~m}, 2 \mathrm{H}), 7.40-7.36(\mathrm{~m}, 1 \mathrm{H}), 7.35-7.29(\mathrm{~m}$, $4 \mathrm{H}), 3.84(\mathrm{~s}, 3 \mathrm{H}), 2.44(\mathrm{~s}, 3 \mathrm{H})$.

${ }^{13} \mathrm{C}\left\{{ }^{1} \mathrm{H}\right\}$ NMR (CDCl$\left.{ }_{3}, 125 \mathrm{MHz}\right): \delta 154.0,143.0,140.0,136.7,129.5,129.4,127.4,122.7,122.5,119.8$, 109.7, 31.8, 21.6.

\subsection{2-(4-methoxyphenyl)-1-methyl-1H-benzo[d]imidazole, 3ua}

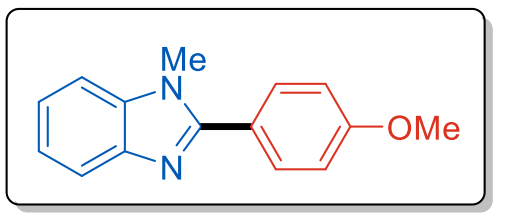

The title compound was prepared according to General Procedure D. The crude material was purified by flash column chromatography (2:1 EtOAc:pentane) to afford 3 ua as a white solid ( $12.3 \mathrm{mg}, 26 \%$ yield). The spectroscopic data matched those reported in the literature. ${ }^{23}$

${ }^{1} \mathrm{H}$ NMR $\left(\mathrm{CDCl}_{3}, 500 \mathrm{MHz}\right): \delta 7.84-7.77(\mathrm{~m}, 1 \mathrm{H}), 7.73-7.67(\mathrm{~m}, 2 \mathrm{H}), 7.38-7.32(\mathrm{~m}, 1 \mathrm{H}), 7.32-7.26(\mathrm{~m}$, $2 \mathrm{H}), 7.07-6.98(\mathrm{~m}, 2 \mathrm{H}), 3.87(\mathrm{~s}, 3 \mathrm{H}), 3.82(\mathrm{~s}, 3 \mathrm{H})$.

${ }^{13} \mathrm{C}\left\{{ }^{1} \mathrm{H}\right\}$ NMR (CDCl, $\left.125 \mathrm{MHz}\right): \delta 160.9,153.8,143.0,136.6,130.9,122.6,122.6,122.4,119.6,114.2$, $109.6,55.5,31.8$. 


\subsection{2-(benzo[d][1,3]dioxol-5-yl)-1-methyl-1H-benzo[d]imidazole, 3va}

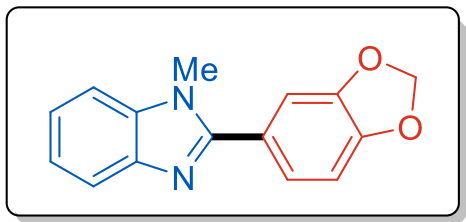

The title compound was prepared according to General Procedure D. The crude material was purified by flash column chromatography (1:1 EtOAc:pentane) to afford 3va as a white solid (16.9 $\mathrm{mg} \mathrm{mg,} \mathrm{34 \%} \mathrm{yield).}$ The spectroscopic data are consistent with those reported in the literature. $^{24}$

${ }^{1} \mathrm{H}$ NMR $\left(\mathrm{CDCl}_{3}, 500 \mathrm{MHz}\right): \delta 7.86-7.76(\mathrm{~m}, 1 \mathrm{H}), 7.40-7.36(\mathrm{~m}, 1 \mathrm{H}), 7.36-7.29(\mathrm{~m}, 2 \mathrm{H}), 7.29-7.22(\mathrm{~m}$, $2 \mathrm{H}), 6.96(\mathrm{~d}, J=8.4 \mathrm{~Hz}, 1 \mathrm{H}), 6.06(\mathrm{~s}, 2 \mathrm{H}), 3.86(\mathrm{~s}, 3 \mathrm{H})$.

${ }^{13} \mathrm{C}\left\{{ }^{1} \mathrm{H}\right\} \operatorname{NMR}\left(\mathrm{CDCl}_{3}, 125 \mathrm{MHz}\right): \delta 153.5,149.2,148.2,142.5,136.6,124.0,123.7,123.0,122.7,119.7$, 109.9, 109.7, 108.7, 101.7, 31.9.

\subsection{1-methyl-2-(o-tolyl)-1H-benzo[d]imidazole, 3wa}

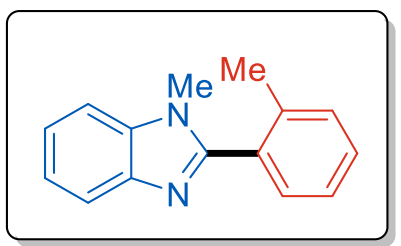

The title compound was synthesized according to General Procedure D. The crude material was purified by flash column chromatography (30\% EtOAc in pentane) affording $3 w a$ as a white solid $(22.0 \mathrm{mg}, 49 \%)$. The spectroscopic data matched those reported in the literature. ${ }^{25}$

${ }^{1} \mathrm{H}$ NMR $\left(\mathrm{CDCl}_{3}, 500 \mathrm{MHz}\right): \delta 7.86-7.81(\mathrm{~m}, 1 \mathrm{H}), 7.44-7.37(\mathrm{~m}, 3 \mathrm{H}), 7.37-$ $7.28(\mathrm{~m}, 4 \mathrm{H}), 3.62(\mathrm{~s}, 3 \mathrm{H}), 2.27(\mathrm{~s}, 3 \mathrm{H})$.

${ }^{13} \mathrm{C}\left\{{ }^{1} \mathrm{H}\right\}$ NMR $\left(\mathrm{CDCl}_{3}, 125 \mathrm{MHz}\right): \delta$ 153.8, 143.0, 138.1, 135.6, 130.5, 130.4, 130.0, 129.9, 125.8, 122.7, $122.3,120.0,109.6,30.7,19.8$.

\subsection{2-([1,1'-biphenyl]-4-yl)-1-methyl-1H-benzo[d]imidazole, 3xa}

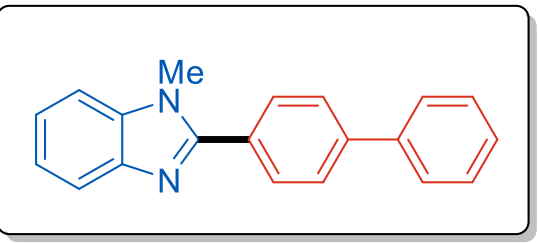

The title compound was synthesized according to General Procedure $\mathbf{C}$. The crude material was purified by flash column chromatography (30\% EtOAc in pentane) affording 3xa as a white solid (30.2 mg, 53\%). The spectroscopic data matched those reported in the literature. ${ }^{26}$

${ }^{1} \mathrm{H}$ NMR $\left(\mathrm{CDCl}_{3}, 500 \mathrm{MHz}\right): \delta 7.92-7.82(\mathrm{~m}, 3 \mathrm{H}), 7.76(\mathrm{~m}, 2 \mathrm{H}), 7.67(\mathrm{~m}, 2 \mathrm{H}), 7.48(\mathrm{t}, J=7.6 \mathrm{~Hz}, 2 \mathrm{H}), 7.40$ $(\mathrm{m}, 2 \mathrm{H}), 7.36-7.31(\mathrm{~m}, 2 \mathrm{H}), 3.89(\mathrm{~s}, 3 \mathrm{H})$

${ }^{13} \mathrm{C}\left\{{ }^{1} \mathrm{H}\right\}$ NMR $\left(\mathrm{CDCl}_{3}, 125 \mathrm{MHz}\right): \delta$ 153.5, 143.0, 142.5, 140.2, 136.8, 129.9, 129.0, 128.9, 127.9, 127.3, $127.2,122.8,122.5,119.8,109.7$, 31.8 . 


\subsection{2-(3,5-dimethoxyphenyl)-1-methyl-1H-benzo[d]imidazole, 3ya}

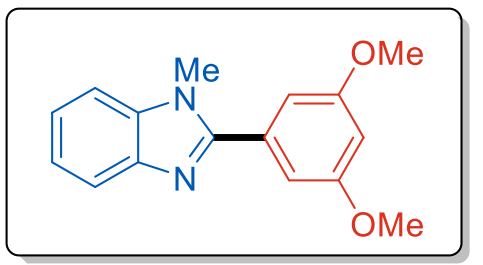

The title compound was synthesized according to General Procedure $\mathbf{C}$. The crude material was purified by flash column chromatography $(30 \%$ EtOAc in pentane) affording 3ya as a white solid $(32.3 \mathrm{mg}, 60 \%)$. The spectroscopic data matched those reported in the literature. ${ }^{27}$

${ }^{1} \mathrm{H} \mathrm{NMR}\left(\mathrm{CDCl}_{3}, 500 \mathrm{MHz}\right): \delta 7.86-7.79(\mathrm{~m}, 1 \mathrm{H}), 7.40-7.34(\mathrm{~m}, 1 \mathrm{H}), 7.34-7.27(\mathrm{~m}, 2 \mathrm{H}), 6.89(\mathrm{~d}, J=2.3$ $\mathrm{Hz}, 2 \mathrm{H}), 6.59(\mathrm{t}, J=2.3 \mathrm{~Hz}, 1 \mathrm{H}), 3.85(\mathrm{~s}, 9 \mathrm{H})$

${ }^{13} \mathrm{C}\left\{{ }^{1} \mathrm{H}\right\}$ NMR $\left(\mathrm{CDCl}_{3}, 125 \mathrm{MHz}\right): \delta 160.9,153.7,142.8,136.6,132.0,123.0,122.6,119.9,109.7,107.6$, $102.1,55.7,31.8$.

\subsection{1-methyl-2-(4-(trifluoromethyl)phenyl)-1H-benzo[d]imidazole, 3za}

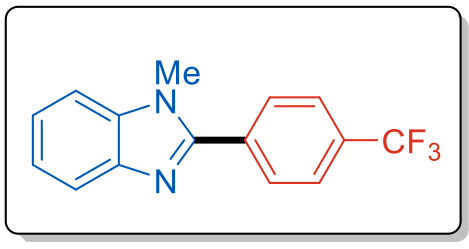

The title compound was synthesized according to General Procedure D. The crude material was purified by flash column chromatography $(30 \%$ EtOAc in pentane) affording $3 z a$ as a white solid (45.3 $\mathrm{mg}, 82 \%)$. The spectroscopic data matched those reported in the literature. ${ }^{21}$

${ }^{1} \mathrm{H}$ NMR $\left(\mathrm{CDCl}_{3}, 500 \mathrm{MHz}\right): \delta 7.86-7.79(\mathrm{~m}, 1 \mathrm{H}), 7.40-7.34(\mathrm{~m}, 1 \mathrm{H}), 7.34-7.27(\mathrm{~m}, 2 \mathrm{H}), 6.89(\mathrm{~d}, J=2.3$ $\mathrm{Hz}, 2 \mathrm{H}), 6.59(\mathrm{t}, J=2.3 \mathrm{~Hz}, 1 \mathrm{H}), 3.85(\mathrm{~s}, 9 \mathrm{H})$

${ }^{13} \mathrm{C}\left\{{ }^{1} \mathrm{H}\right\}$ NMR (CDCl, $\left.125 \mathrm{MHz}\right): \delta 160.9,153.7,142.8,136.6,132.0,123.0,122.6,119.9,109.7,107.6$, $102.1,55.7,31.8$.

${ }^{19}$ F NMR $\left(\mathrm{CDCl}_{3}, 377 \mathrm{MHz}\right): \delta-62.8$

\subsection{2-(2,5-dimethylphenyl)-1-methyl-1H-benzo[d]imidazole, 3ab}

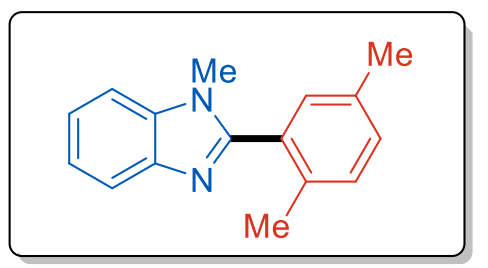

The title compound was synthesized according to General Procedure D. The crude material was purified by flash column chromatography $(30 \%$ EtOAc in pentane) affording 3ab as a clear oil (30.3 mg, 64\%).

${ }^{1}{ }^{H}$ NMR $\left(\mathrm{CDCl}_{3}, 500 \mathrm{MHz}\right): \delta 7.86-7.78(\mathrm{~m}, 1 \mathrm{H}), 7.44-7.37(\mathrm{~m}, 1 \mathrm{H}), 7.36-7.28(\mathrm{~m}, 2 \mathrm{H}), 7.24-7.18(\mathrm{~m}$, $3 \mathrm{H}), 3.63(\mathrm{~s}, 3 \mathrm{H}), 2.37(\mathrm{~s}, 3 \mathrm{H}), 2.21(\mathrm{~s}, 3 \mathrm{H})$ 
${ }^{13} \mathrm{C}\left\{{ }^{1} \mathrm{H}\right\}$ NMR $\left(\mathrm{CDCl}_{3}, 125 \mathrm{MHz}\right): \delta$ 154.2, 135.7, 135.5, 134.8, 131.0, 130.8, 130.4, 129.9, 122.7, 122.4, 120.0, 109.6, 30.8, 21.0, 19.3.

IR (neat, cm cm $^{-1}$ ) 3041, 2949, 2924, 2857, 1719, 1607, 1522, 1508, 1492, 1458, 1436, 1397, 1377, 1325, $1280,1250,1179,1112,1006,816,760,742,427$

Mass: DART, calc for $\mathrm{C}_{16} \mathrm{H}_{17} \mathrm{~N}_{2} 237.13862[\mathrm{M}+\mathrm{H}]^{+}$, found 237.13869.

\subsection{1-methyl-2-(naphthalen-2-yl)-1H-benzo[d]imidazole, 3bb}

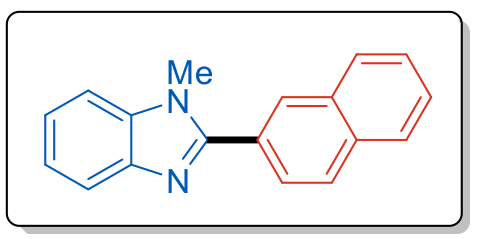

The title compound was synthesized according to General Procedure $\mathbf{C}$. The crude material was purified by flash column chromatography $(30 \%$ EtOAc in pentane) affording $\mathbf{3 b b}$ as a white solid (16.9 $\mathrm{mg}, 33 \%)$. The spectroscopic data matched those reported in the literature. ${ }^{28}$

${ }^{1} \mathrm{H} \mathrm{NMR}\left(\mathrm{CDCl}_{3}, 500 \mathrm{MHz}\right): \delta 8.25(\mathrm{~s}, 1 \mathrm{H}), 7.99(\mathrm{~d}, \mathrm{~J}=8.5 \mathrm{~Hz}, 1 \mathrm{H}), 7.97-7.83(\mathrm{~m}, 4 \mathrm{H}), 7.61-7.52(\mathrm{~m}, 2 \mathrm{H})$, $7.44-7.39(\mathrm{~m}, 1 \mathrm{H}), 7.38-7.32(\mathrm{~m}, 2 \mathrm{H}), 3.92(\mathrm{~s}, 3 \mathrm{H})$

${ }^{13} \mathrm{C}\left\{{ }^{1} \mathrm{H}\right\}$ NMR $\left(\mathrm{CDCl}_{3}, 125 \mathrm{MHz}\right): \delta$ 153.8, 143.1, 136.8, 133.7, 133.0, 129.5, 128.6, 128.6, 127.9, 127.6, $127.3,126.9,126.4,123.0,122.6,119.9,109.8,32.0$.

\subsection{H-benzo[4,5]imidazo[2,1-a]isoindole, 3cb}

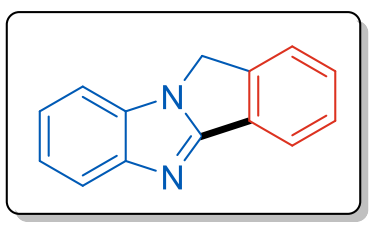

The title compound was prepared according to General Procedure $\mathbf{C}$. The crude material was purified by flash column chromatography (2:1 EtOAc:pentane) to afford $\mathbf{3 c b}$ as a white solid ( $21.7 \mathrm{mg}, 53 \%$ ). The spectroscopic data matched those reported in the literature. ${ }^{29}$

${ }^{1} \mathrm{H} \mathrm{NMR}\left(\mathrm{CDCl}_{3}, 500 \mathrm{MHz}\right): \delta 8.03(\mathrm{~d}, J=6.9 \mathrm{~Hz}, 1 \mathrm{H}), 7.85-7.79(\mathrm{~m}, 1 \mathrm{H}), 7.55-$ $7.42(\mathrm{~m}, 3 \mathrm{H}), 7.40-7.35(\mathrm{~m}, 1 \mathrm{H}), 7.29-7.17(\mathrm{~m}, 2 \mathrm{H}), 4.96(\mathrm{~s}, 2 \mathrm{H})$.

${ }^{13} \mathrm{C}\left\{{ }^{1} \mathrm{H}\right\}$ NMR $\left(\mathrm{CDCl}_{3}, 125 \mathrm{MHz}\right): \delta 152.2,143.0,136.7,133.9,131.7(\mathrm{q}, J=32.8 \mathrm{~Hz}), 129.9,125.8$ (q, $J=3.8$ $\mathrm{Hz}), 124.0$ (q, J = 272.4 Hz), 123.5, 122.9, 120.2, 109.9, 31.8. 


\subsection{2 (4-(1-methyl-1H-benzo[d]imidazol-2-yl)phenyl)(4-phenylpiperazin-1-yl)methanone, 3db}

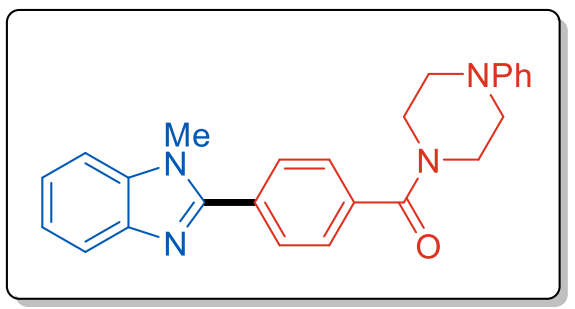

The title compound was prepared according to General Procedure C. The crude material was purified by flash column chromatography (50\% EtOAc in pentane) to afford $3 y$ as a white solid $(37.1 \mathrm{mg}, 47 \%)$. Note that $\mathbf{3 d b}$ should be stored at $-20{ }^{\circ} \mathrm{C}$. Storage at room temperature leads to discolouration of the material into a pink solid.

${ }^{1} \mathrm{H}$ NMR $\left(\mathrm{CDCl}_{3}, 500 \mathrm{MHz}\right): \delta 7.90-7.80(\mathrm{~m}, 3 \mathrm{H}), 7.64-7.56(\mathrm{~m}, 2 \mathrm{H}), 7.45-7.25(\mathrm{~m}, 5 \mathrm{H}), 6.98-6.88(\mathrm{~m}$, 2H), 3.96 (br s, 2H), $3.88(\mathrm{~s}, 3 \mathrm{H}), 3.61(\mathrm{br} \mathrm{s}, 2 \mathrm{H}), 3.39-2.98(\mathrm{~m}, 4 \mathrm{H})$.

${ }^{13} \mathrm{C}\left\{{ }^{1} \mathrm{H}\right\}$ NMR $\left(\mathrm{CDCl}_{3}, 125 \mathrm{MHz}\right): \delta$ 169.6, 152.7, 150.9, 142.8, 137.0, 136.6, 131.6, 129.8, 129.4, 127.6, $123.3,122.9,120.8,120.0,116.9,109.9,50.1,49.6,47.7,42.3,31.8$.

IR (neat, cm cm $^{-1}$ : 2962, 2932, 2865, 1622, 1604, 1495, 1450, 1392, 1332, 1232, 1008, 857

Mass: DART, calc for $\mathrm{C}_{25} \mathrm{H}_{25} \mathrm{~N}_{4} \mathrm{O} 397.20229[\mathrm{M}+\mathrm{H}]^{+}$, found 397.20284.

Melting point: $180-182^{\circ} \mathrm{C}$

3.33 ((3aR,5R,5aS,8aS,8bR)-2,2,7,7-tetramethyltetrahydro-5H-bis([1,3]dioxolo)[4,5-b:4',5'-d]pyran-5yl)methyl 4-(1-methyl-1H-benzo[d]imidazol-2-yl)benzoate, 3eb

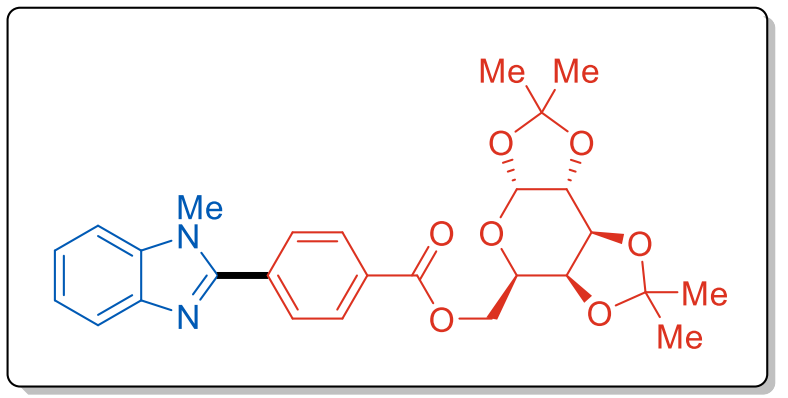

The title compound was prepared according to General Procedure C. The crude material was purified by flash column chromatography $(40 \%$ EtOAc in pentane) to afford $3 \mathrm{eb}$ as a white foam. The material becomes a white solid following extended drying under high vacuum.

${ }^{1} \mathrm{H} \mathrm{NMR}\left(\mathrm{CDCl}_{3}, 500 \mathrm{MHz}\right): \delta 8.21(\mathrm{~d}, J=8.3 \mathrm{~Hz}, 2 \mathrm{H})$, $7.92-7.81(\mathrm{~m}, 3 \mathrm{H}), 7.45-7.39(\mathrm{~m}, 1 \mathrm{H}), 7.40-7.29(\mathrm{~m}, 2 \mathrm{H}), 5.58(\mathrm{~d}, J=4.9 \mathrm{~Hz}, 1 \mathrm{H}), 4.67(\mathrm{dd}, J=7.9,2.5$ $\mathrm{Hz}, 1 \mathrm{H}), 4.57(\mathrm{dd}, J=11.5,4.7 \mathrm{~Hz}, 1 \mathrm{H}), 4.48(\mathrm{dd}, J=11.5,7.7 \mathrm{~Hz}, \mathrm{H}), 4.37-4.33(\mathrm{~m}, 2 \mathrm{H}), 4.22(\mathrm{ddd}, J=6.9$, 4.7, $1.9 \mathrm{~Hz}, 1 \mathrm{H}), 3.90(\mathrm{~s}, 3 \mathrm{H}), 1.53(\mathrm{~s}, 3 \mathrm{H}), 1.49(\mathrm{~s}, 3 \mathrm{H}), 1.37(\mathrm{~s}, 3 \mathrm{H}), 1.34(\mathrm{~s}, 3 \mathrm{H})$.

${ }^{13} \mathrm{C}\left\{{ }^{1} \mathrm{H}\right\}$ NMR (DMSO- $\left.d_{6}, 125 \mathrm{MHz}\right): \delta$ 165.9, 152.5, 142.6, 136.7, 134.3, 131.3, 130.2, 129.6, 123.5, 123.1, $120.1,109.9,109.0,96.5,71.7,71.3,70.9,70.7,68.2,66.3,64.4,62.5,32.0,26.2,26.1,25.1,24.6$.

IR (neat, cm ${ }^{-1}$ ): 2995, 2935, 2865, 1720, 1612, 1496, 1455, 1380, 1254, 1205, 1163, 1009, 1104, 1072, 845, 743 
Mass: DART, calc for $\mathrm{C}_{27} \mathrm{H}_{31} \mathrm{~N}_{2} \mathrm{O}_{7} 495.21258[\mathrm{M}+\mathrm{H}]^{+}$, found 495.21295 .

Melting point: $64-66^{\circ} \mathrm{C}$

4. Mechanistic Investigations

\subsection{Control Experiments Confirming the Necessity of the Nickel Catalyst and Zn}

Scheme S8. Confirming the need for both nickel and Zn in the present methodology

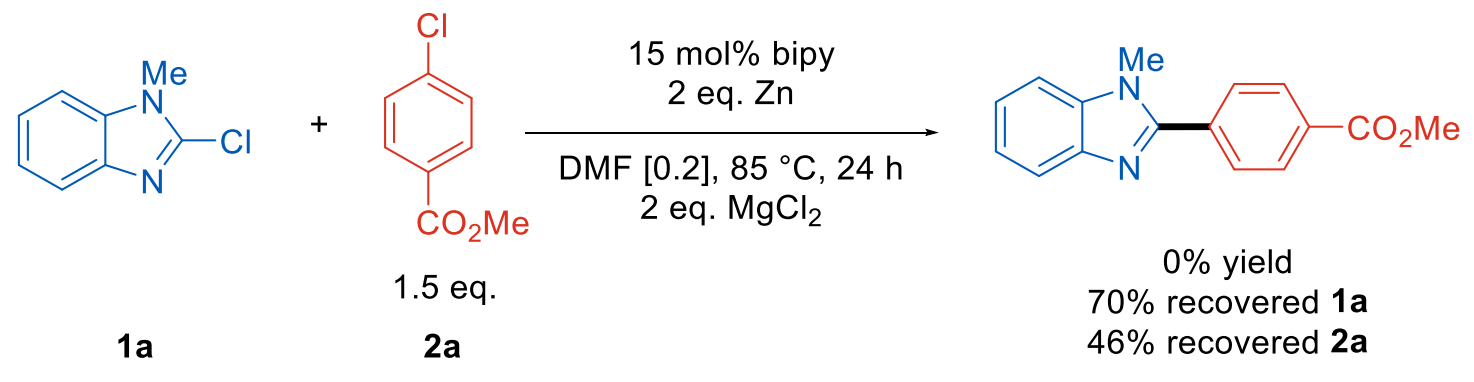<smiles>COC(=O)c1ccc(Cl)cc1</smiles>

1.5 eq.

$1 \mathrm{a}$

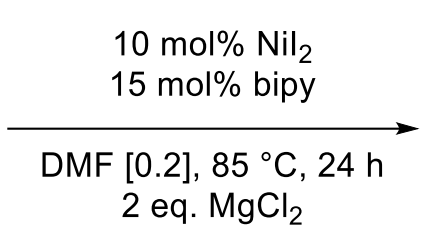

2 eq. $\mathrm{MgCl}_{2}$

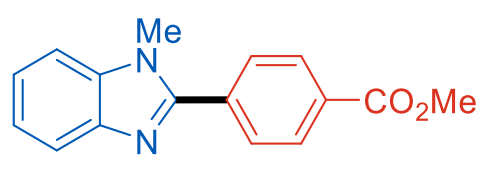

$0 \%$ yield

$79 \%$ recovered 1 a $74 \%$ recovered $\mathbf{2 a}$

\subsubsection{Procedure for the Cross-Electrophile Coupling in the Absence of Nickel}

An oven-dried 2-dram vial was charged with a PTFE-coated stir bar and cooled under a positive pressure of argon. To the vial was added sequentially $1 \mathrm{a}$ ( $33.3 \mathrm{mg}, 0.2 \mathrm{mmol}, 1 \mathrm{eq}$ )), $2 \mathrm{a}$ (51.2 $\mathrm{mg}, 0.3$ mmol, 1.5 eq.), 2,2'-bipyridine (4.7 mg, 15 mol\%), $\mathrm{Zn} \mathrm{(26.2} \mathrm{mg,} 0.4$ mmol, 2 eq.), and $\mathrm{MgCl}_{2}$ (38.1 mg, 0.4 $\mathrm{mmol}, 2$ eq.). The vial was sealed with a screw cap fitted with a PTFE-faced silicone septum and then DMF $(1 \mathrm{~mL}, 0.2 \mathrm{M}$ relative to $1 \mathrm{a}$ ) was added at room temperature under an atmosphere of argon. The vial was placed in an oil bath pre-heated to $85^{\circ} \mathrm{C}$ and stirred for $24 \mathrm{~h}$.

The reaction mixture was cooled to room temperature and filtered through a short plug of silica gel, eluting with ethyl acetate. The filtrate was then washed twice with water and twice with brine. The organic layer was then dried over $\mathrm{MgSO}_{4}$ and then filtered over a short plug of silica gel, eluting with ethyl acetate. A known amount of 1,3,5-trimethoxybenzene was added to the crude and the sample was completely dissolved in $1 \mathrm{~mL}$ of $\mathrm{CDCl}_{3}$. The sample was analyzed by NMR and the yields were determined based on the integration of the compounds relative to 1,3,5-trimethoxybenzene. 


\subsubsection{Procedure for the Cross-Electrophile Coupling in the Absence of Zinc}

An oven-dried 2-dram vial was charged with a PTFE-coated stir bar and cooled under a positive pressure of argon. To the vial was added sequentially 1a $(33.3 \mathrm{mg}, 0.2 \mathrm{mmol}, 1$ eq.), 2 a $(51.2 \mathrm{mg}, 0.3$ mmol, 1.5 eq.), $\mathrm{Nil}_{2}$ (6.3 mg, $10 \mathrm{~mol} \%$ ), 2,2'-bipyridine (4.7 mg, $15 \mathrm{~mol} \%$ ), and $\mathrm{MgCl}_{2}$ (38.1 mg, $0.4 \mathrm{mmol}$, 2 eq.). The vial was sealed with a screw cap fitted with a PTFE-faced silicone septum and then DMF ( $1 \mathrm{~mL}$, $0.2 \mathrm{M}$ relative to $1 \mathrm{a}$ ) was added at room temperature under an atmosphere of argon. The vial was placed in an oil bath pre-heated to $85^{\circ} \mathrm{C}$ and stirred for $24 \mathrm{~h}$.

The reaction mixture was cooled to room temperature and filtered through a short plug of silica gel, eluting with ethyl acetate. The filtrate was then washed twice with water and twice with brine. The organic layer was then dried over $\mathrm{MgSO}_{4}$, and then filtered over a short plug of silica gel, eluting with ethyl acetate. A known amount of 1,3,5-trimethoxybenzene was added to the crude and the sample was completely dissolved in $1 \mathrm{~mL}$ of $\mathrm{CDCl}_{3}$. The sample was analyzed by NMR and the yields were determined based on the integration of the compounds relative to 1,3,5-trimethoxybenzene.

\subsection{Testing for Possible Formation of Negishi-type Intermediates}

Scheme S9. Testing for Negishi-type intermediates via an iodine quench<smiles>Cn1c(Cl)nc2ccccc21</smiles>

$1 \mathrm{a}$

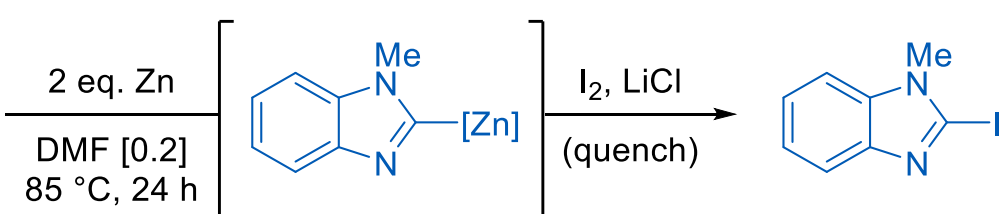

x eq. $\mathrm{MgCl}_{2}$
- $0 \%$ yield (not detected with MS) $72 \%$ recovered SM $x=0$

- $0 \%$ yield (not detected with MS) $94 \%$ recovered SM $x=2$<smiles>COC(=O)c1ccc(Cl)cc1</smiles>

2a

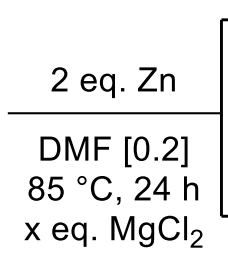

$\mathrm{x}$ eq. $\mathrm{MgCl}_{2}$<smiles>COC(=O)c1ccc(C#N)cc1</smiles><smiles>COC(=O)c1ccc(I)cc1</smiles>

- $0 \%$ yield (not detected with MS)

$94 \%$ recovered SM

$$
x=0
$$

- $0 \%$ yield (not detected with MS)

$56 \%$ recovered SM

$$
x=2
$$




\subsubsection{Preparation of the $\mathrm{I}_{2} / \mathrm{LiCl}$ Quenching Solution}

The $\mathrm{I}_{2} / \mathrm{LiCl}$ quenching solution was prepared as reported by Weix et al. with slight modifications. ${ }^{30} \mathrm{~A}$ flame-dried scintillation vial was charged with a dry PTFE-coated stir bar and cooled under a positive pressure of argon. $\mathrm{LiCl}$ (127 mg, $3.00 \mathrm{mmol}$ ) was added, followed by THF $(6.0 \mathrm{~mL})$. The scintillation vial was lined with Teflon tape and sealed with a Teflon screw cap. The solution was stirred at room temperature overnight until all solids were dissolved, resulting in a $0.5 \mathrm{M} \mathrm{LiCl} \mathrm{THF} \mathrm{solution.}$

A separate scintillation vial was charged with a dry PTFE-coated stir bar and cooled under a positive pressure of argon. $\mathrm{I}_{2}(254 \mathrm{mg}, 1.00 \mathrm{mmol})$ was weighed into the scintillation vial and $4 \mathrm{~mL}$ of the $0.5 \mathrm{M}$ $\mathrm{LiCl}$ solution was added. The solution was stirred at room temperature for 1 hour before being used.

\subsubsection{Procedure for the Reactions of $1 \mathrm{a}$ and $2 \mathrm{a}$ with $\mathrm{Zn}$}

An oven-dried 2-dram vial was charged with a PTFE-coated stir bar and cooled under a positive pressure of argon. To the vial was added sequentially $1 \mathrm{a}(33.3 \mathrm{mg}, 0.2 \mathrm{mmol}, 1$ eq.) or $2 \mathrm{a}(34.1 \mathrm{mg}, 0.2$ mmol, 1.0 eq.), $\mathrm{Zn}\left(26.2 \mathrm{mg}, 0.4 \mathrm{mmol}, 2\right.$ eq.), and $\mathrm{MgCl}_{2}$ (either 0 eq. or $38.1 \mathrm{mg}, 0.4 \mathrm{mmol}$, 2 eq.). The vial was sealed with a screw cap fitted with a PTFE-faced silicone septum and then DMF $(1 \mathrm{~mL}, 0.2 \mathrm{M}$ relative to $1 \mathbf{a}$ or $\mathbf{2 a}$ ) was added at room temperature under an atmosphere of argon. The vial was placed in an oil bath pre-heated to $85^{\circ} \mathrm{C}$ and stirred for $24 \mathrm{~h}$.

The reaction mixture was cooled to room temperature and $1 \mathrm{~mL}$ of the $\mathrm{I}_{2} / \mathrm{LiCl}$ solution was added. The solution was stirred for $\mathbf{3 0}$ minutes before the crude mixture was filtered through a short plug of silica gel, eluting with ethyl acetate. The filtrate was then washed twice with water and twice with brine. The organic layer was then dried over $\mathrm{MgSO}_{4}$ and then filtered over a short plug of silica gel, eluting with ethyl acetate. A known amount of 1,3,5-trimethoxybenzene was added to the crude, and the sample was completely dissolved in $1 \mathrm{~mL}$ of $\mathrm{CDCl}_{3}$. The sample was analyzed by ASAP-MS using an APCl ionization source and by NMR. The yields were determined based on the integration of the compounds relative to 1,3,5-trimethoxybenzene.

\subsection{Testing for the Formation of Radical Intermediates}

Table S6. Probing for radical intermediates by addition of a radical scavenger. ${ }^{[a]}$

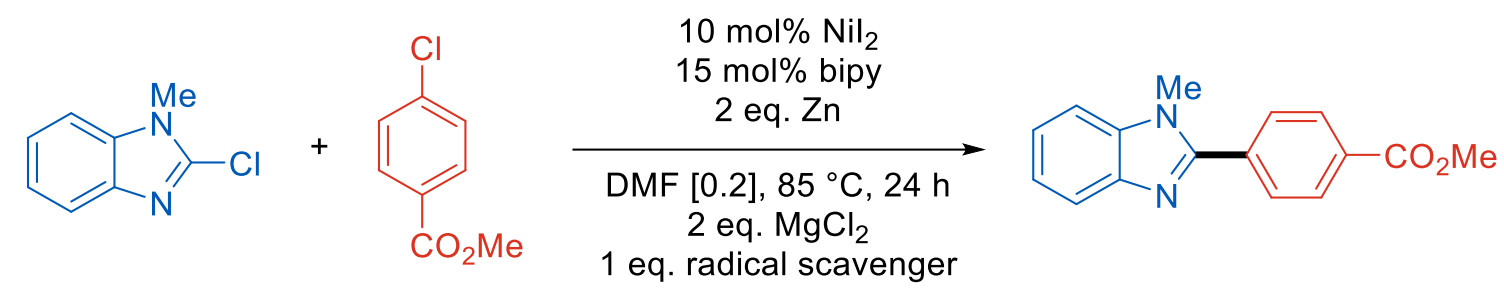

$1 \mathrm{a}$

$2 a$

$3 a a$

\begin{tabular}{cccccc}
\hline Entry & $\begin{array}{c}\text { Radical } \\
\text { Scavenger }\end{array}$ & $\begin{array}{c}\text { Remaining 1a } \\
(\%)^{[\mathrm{b}]}\end{array}$ & $\begin{array}{c}\text { Remaining 2a } \\
(\%)^{[\mathrm{b}]}\end{array}$ & $\begin{array}{c}\text { Yield 3aa } \\
(\%)^{[\mathrm{b}]}\end{array}$ & $\begin{array}{c}\text { Recovered } \\
\text { Scavenger } \\
(\%)^{[\mathrm{b}]}\end{array}$ \\
\hline 1 & TEMPO & 0 & 27 & 15 & - \\
\hline
\end{tabular}




\begin{tabular}{cccccc}
\hline 2 & BHT & 0 & 0 & 98 & $85^{\text {[d] }}$ \\
3 & $\begin{array}{c}1,1- \\
\text { diphenylethylene }\end{array}$ & 0 & 0 & 72 & 56
\end{tabular}

[a] Reactions were carried out on $0.2 \mathrm{mmol}$ scale with a 1:1.5 ratio of 1a:2a. ${ }^{[b]}$ Yield was determined by ${ }^{1} \mathrm{H}$ NMR analysis of the crude reaction mixture following workup using 1,3,5-trimethoxybenzene as the internal standard.

\subsubsection{Procedure for the Reactions of $1 \mathrm{a}$ and $2 \mathrm{a}$ in the presence of a radical scavenger}

An oven-dried 2-dram vial was charged with a PTFE-coated stir bar and cooled under a positive pressure of argon. To the vial was added sequentially $1 \mathrm{a}(33.3 \mathrm{mg}, 0.2 \mathrm{mmol}, 1 \mathrm{eq}$ ) ), $2 \mathrm{a}(51.2 \mathrm{mg}, 0.3$ mmol, 1.5 eq.), $\mathrm{Nil}_{2}$ (6.3 mg, $\left.10 \mathrm{~mol} \%\right)$, 2,2'-bipyridine (4.7 mg, $\left.15 \mathrm{~mol} \%\right), \mathrm{Zn} \mathrm{(26.2} \mathrm{mg,} 0.4 \mathrm{mmol}, 2$ eq.), $\mathrm{MgCl}_{2}$ (38.1 mg, $0.4 \mathrm{mmol}, 2$ eq.), and the appropriate radical scavenger ( $0.2 \mathrm{mmol}, 1$ eq.). The vial was sealed with a screw cap fitted with a PTFE-faced silicone septum and then DMF ( $1 \mathrm{~mL}, 0.2 \mathrm{M}$ relative to 1a) was added at room temperature under an atmosphere of argon. The vial was placed in an oil bath preheated to $85^{\circ} \mathrm{C}$ and stirred for $24 \mathrm{~h}$.

The reaction mixture was cooled to room temperature and the crude mixture was filtered through a short plug of silica gel, eluting with ethyl acetate. The filtrate was then washed twice with water and twice with brine. The organic layer was then dried over $\mathrm{MgSO}_{4}$ and then filtered over a short plug of silica gel, eluting with ethyl acetate. A known amount of 1,3,5-trimethoxybenzene was added to the crude, and the sample was completely dissolved in $1 \mathrm{~mL}$ of $\mathrm{CDCl}_{3}$. The sample was analyzed by NMR using a 10 second relaxation delay. The yields were determined based on the integration of the compounds relative to 1,3,5trimethoxybenzene.

\subsection{Testing for Homocoupling of the Heteroaryl and Aryl Chloride}

Scheme S10. Subjecting $\mathbf{1 a}$ and $\mathbf{2} \mathbf{a}$ to the reaction conditions in the absence of the other.
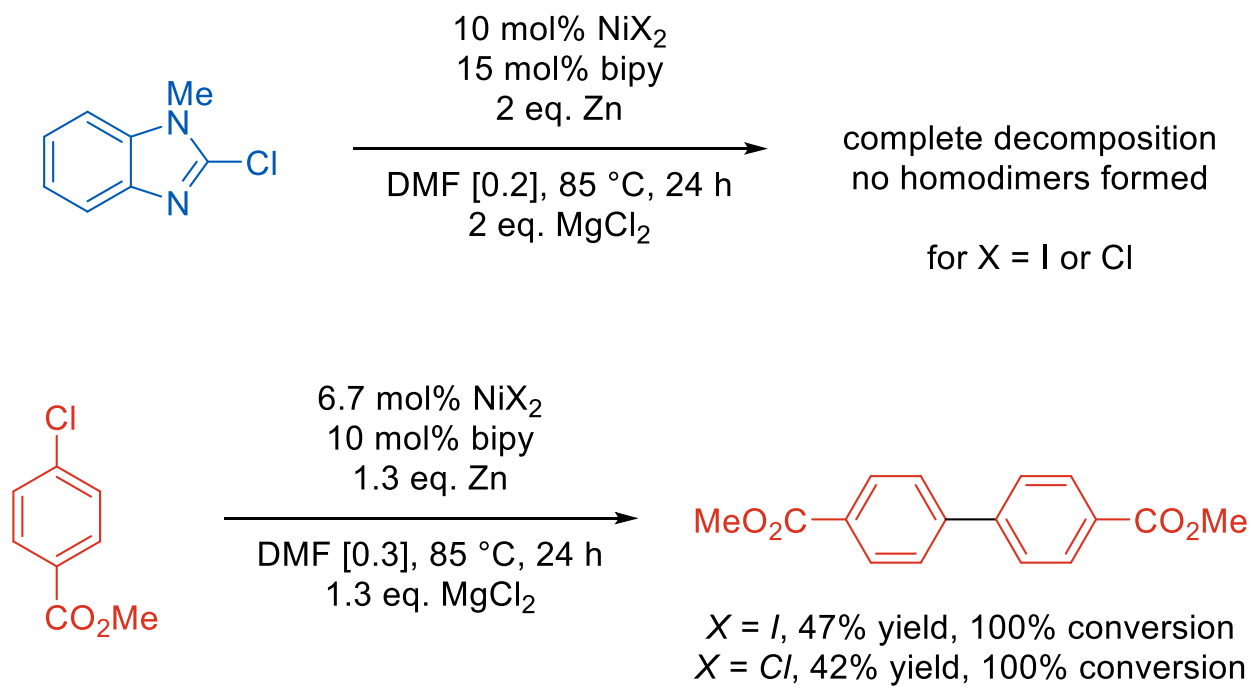


\subsubsection{Procedure for the Reaction of $1 a$ absence of $2 a$}

An oven-dried 2-dram vial was charged with a PTFE-coated stir bar and cooled under a positive pressure of argon. To the vial was added sequentially $1 \mathrm{a}\left(33.3 \mathrm{mg}, 0.2 \mathrm{mmol}, 1 \mathrm{eq}\right.$.), $\mathrm{Nil}_{2}$ ( $\left.6.3 \mathrm{mg}, 10 \mathrm{~mol} \%\right)$ or $\mathrm{NiCl}_{2}$ (dme) (4.4 mg, $10 \mathrm{~mol} \%$ ), 2,2'-bipyridine ( $4.7 \mathrm{mg}, 15 \mathrm{~mol} \%$ ), $\mathrm{Zn} \mathrm{(26.2} \mathrm{mg,} 0.4 \mathrm{mmol}, 2$ eq.), and $\mathrm{MgCl}_{2}$ (38.1 mg, $0.4 \mathrm{mmol}, 2 \mathrm{eq}$.). The vial was sealed with a screw cap fitted with a PTFE-faced silicone septum and then DMF ( $1 \mathrm{~mL}, 0.2 \mathrm{M}$ relative to $1 \mathrm{a}$ ) was added at room temperature under an atmosphere of argon. The vial was placed in an oil bath pre-heated to $85^{\circ} \mathrm{C}$ and stirred for $24 \mathrm{~h}$.

The reaction mixture was cooled to room temperature and the crude mixture was filtered through a short plug of silica gel, eluting with ethyl acetate. The filtrate was then washed twice with water and twice with brine. The organic layer was then dried over $\mathrm{MgSO}_{4}$ and then filtered over a short plug of silica gel, eluting with ethyl acetate. A known amount of 1,3,5-trimethoxybenzene was added to the crude, and the sample was completely dissolved in $1 \mathrm{~mL}$ of $\mathrm{CDCl}_{3}$. The sample was analyzed by NMR using a 10 second relaxation delay. The yields were determined based on the integration of the compounds relative to 1,3,5trimethoxybenzene.

\subsubsection{Procedure for the Reactions of $2 a$ absence of $1 a$}

An oven-dried 2-dram vial was charged with a PTFE-coated stir bar and cooled under a positive pressure of argon. To the vial was added sequentially $2 \mathrm{a}\left(51.2 \mathrm{mg}, 0.3 \mathrm{mmol}, 1 \mathrm{eq}\right.$.), $\mathrm{Nil}_{2}$ ( $\left.6.3 \mathrm{mg}, 6.7 \mathrm{~mol} \%\right)$ or $\mathrm{NiCl}_{2}$ (dme) (4.4 mg, $10 \mathrm{~mol} \%$ ), 2,2'-bipyridine (4.7 mg, $10 \mathrm{~mol} \%$ ), Zn (26.2 mg, 0.4 mmol, 1.3 eq.), and $\mathrm{MgCl}_{2}$ (38.1 mg, $0.4 \mathrm{mmol}, 1.3$ eq.). The vial was sealed with a screw cap fitted with a PTFE-faced silicone septum and then DMF ( $1 \mathrm{~mL}, 0.3 \mathrm{M}$ relative to $2 \mathrm{a}$ ) was added at room temperature under an atmosphere of argon. The vial was placed in an oil bath pre-heated to $85^{\circ} \mathrm{C}$ and stirred for $24 \mathrm{~h}$.

The reaction mixture was cooled to room temperature and the crude mixture was filtered through a short plug of silica gel, eluting with ethyl acetate. The filtrate was then washed twice with water and twice with brine. The organic layer was then dried over $\mathrm{MgSO}_{4}$ and then filtered over a short plug of silica gel, eluting with ethyl acetate. A known amount of 1,3,5-trimethoxybenzene was added to the crude, and the sample was completely dissolved in $1 \mathrm{~mL}$ of $\mathrm{CDCl}_{3}$. The sample was analyzed by NMR using a 10 second relaxation delay. The yields were determined based on the integration of the compounds relative to 1,3,5trimethoxybenzene.

\subsection{Testing for the Effect of lodide in the Reaction}

Table S7. Varying the halide present in the reaction

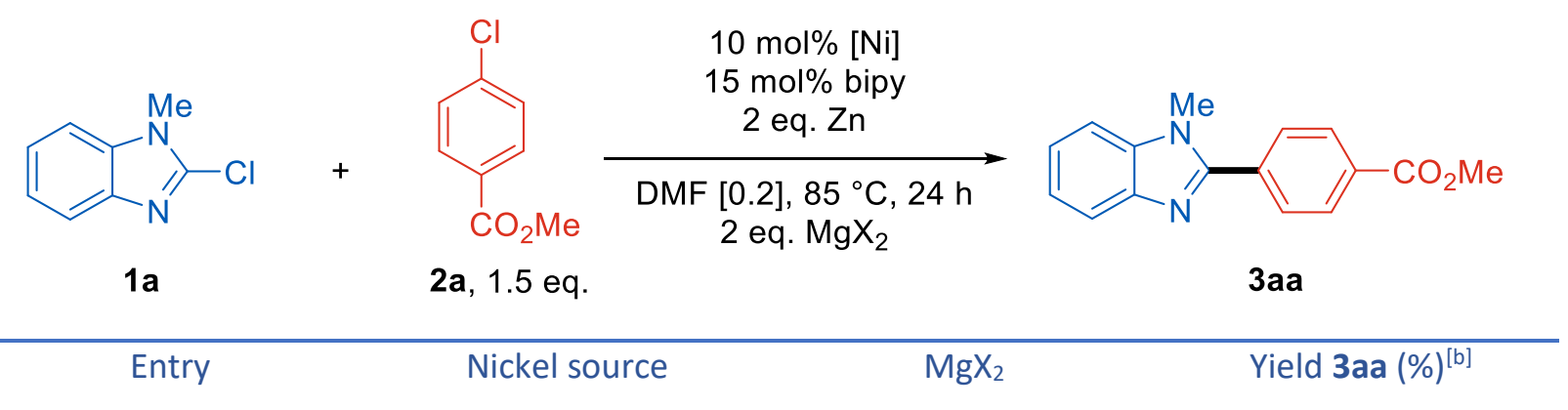




\begin{tabular}{cccc}
\hline 1 & $\mathrm{Nil}_{2}$ & $\mathrm{MgCl}_{2}$ & 94 \\
2 & $\mathrm{NiCl}_{2}(\mathrm{dme})$ & $\mathrm{MgCl}_{2}{ }^{[c]}$ & 54 \\
3 & $\mathrm{NiCl}_{2}(\mathrm{dme})$ & $\mathrm{MgCl}_{2}$ & 48 \\
4 & $\mathrm{Nil}_{2}$ & $\mathrm{Mgl}_{2}$ & 93 \\
5 & $\mathrm{NiCl}_{2}(\mathrm{dme})$ & $\mathrm{Mgl}_{2}$ & 74 \\
6 & $\mathrm{NiCl}_{2}(\mathrm{dme})$ & 1.9 eq. $\mathrm{MgCl}_{2}$ and 0.1 & 76
\end{tabular}

[a] Reactions were carried out on $0.2 \mathrm{mmol}$ scale with a 1:1.5 ratio of 1a:2a. ${ }^{[b]}$ Yield was determined by ${ }^{1} \mathrm{H}$ NMR analysis of the crude reaction mixture following workup using 1,3,5-trimethoxybenzene as the internal standard. [c] 1 equivalent of $\mathrm{MgCl}_{2}$ was added instead of 2 .

\subsubsection{Procedure for the Reaction in the Presence of Various Magnesium Salts}

An oven-dried 2-dram vial was charged with a PTFE-coated stir bar and cooled under a positive pressure of argon. To the vial was added sequentially $1 \mathrm{a}\left(33.3 \mathrm{mg}, 0.2 \mathrm{mmol}, 1\right.$ eq.), either $\mathrm{NiCl}_{2}(\mathrm{dme})(4.4$ $\mathrm{mg}, 10 \mathrm{~mol} \%$ ) or $\mathrm{Nil}_{2}$ (6.3 mg, $\left.10 \mathrm{~mol} \%\right), 2,2^{\prime}$-bipyridine (4.7 mg, $\left.15 \mathrm{~mol} \%\right)$, and $\mathrm{Zn} \mathrm{(26.2} \mathrm{mg,} 0.4 \mathrm{mmol}, 2$ eq.). At this point, $\mathrm{MgCl}_{2}$ (38.1 mg, $0.4 \mathrm{mmol}, 2$ eq. or $19.0 \mathrm{mg}, 0.2 \mathrm{mmol}, 1$ eq.) or $\mathrm{Mgl}_{2}(111.2 \mathrm{mg}, 0.4$ $\mathrm{mmol}, 2$ eq.) was added. The vial was sealed with a screw cap fitted with a PTFE-faced silicone septum and then DMF (1 mL, $0.2 \mathrm{M}$ relative to $1 \mathrm{a}$ ) was added at room temperature under an atmosphere of argon. The vial was placed in an oil bath pre-heated to $85^{\circ} \mathrm{C}$ and stirred for $24 \mathrm{~h}$.

The reaction mixture was cooled to room temperature and the crude mixture was filtered through a short plug of silica gel, eluting with ethyl acetate. The filtrate was then washed twice with water and twice with brine. The organic layer was then dried over $\mathrm{MgSO}_{4}$ and then filtered over a short plug of silica gel, eluting with ethyl acetate. A known amount of 1,3,5-trimethoxybenzene was added to the crude, and the sample was completely dissolved in $1 \mathrm{~mL}$ of $\mathrm{CDCl}_{3}$. The sample was analyzed by NMR using a 10 second relaxation delay. The yields were determined based on the integration of the compounds relative to 1,3,5trimethoxybenzene.

\subsubsection{Procedure for the Reaction in the Presence of $\mathrm{MgCl}_{2}$ and $\mathrm{Mgl}_{2}$}

An oven-dried 2-dram vial was charged with a PTFE-coated stir bar and cooled under a positive pressure of argon. To the vial was added sequentially $1 \mathrm{a}$ ( $33.3 \mathrm{mg}, 0.2 \mathrm{mmol}, 1 \mathrm{eq}$.), $\mathrm{NiCl}_{2}(\mathrm{dme})(4.4 \mathrm{mg}$, 10 mol\%), 2,2'-bipyridine (4.7 mg, 15 mol\%), Zn (26.2 mg, 0.4 mmol, 2 eq.), $\mathrm{MgCl}_{2}$ (36.2 mg, $0.38 \mathrm{mmol}$, 1.9 eq.), and $\mathrm{Mgl}_{2}(5.6 \mathrm{mg}, 0.02 \mathrm{mmol}, 0.1$ eq.) was added. The vial was sealed with a screw cap fitted with a PTFE-faced silicone septum and then DMF $(1 \mathrm{~mL}, 0.2 \mathrm{M}$ relative to $1 \mathrm{a})$ was added at room temperature under an atmosphere of argon. The vial was placed in an oil bath pre-heated to $85^{\circ} \mathrm{C}$ and stirred for $24 \mathrm{~h}$.

The reaction mixture was cooled to room temperature and the crude mixture was filtered through a short plug of silica gel, eluting with ethyl acetate. The filtrate was then washed twice with water and twice with brine. The organic layer was then dried over $\mathrm{MgSO}_{4}$ and then filtered over a short plug of silica gel, eluting with ethyl acetate. A known amount of 1,3,5-trimethoxybenzene was added to the crude, and the 
sample was completely dissolved in $1 \mathrm{~mL}$ of $\mathrm{CDCl}_{3}$. The sample was analyzed by NMR using a 10 second relaxation delay. The yields were determined based on the integration of the compounds relative to 1,3,5trimethoxybenzene.

\subsubsection{Synthesis of Methyl-4-iodobenzoate}<smiles>O=C(O)c1ccc(I)cc1</smiles>

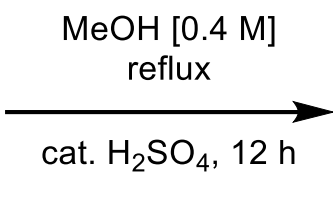<smiles>COC(=O)c1ccc(I)cc1</smiles>

$\mathrm{I}-2 \mathrm{a}, 88 \%$ yield

This reaction was not performed under inert atmosphere and glassware was not flame- or ovendried. A round-bottomed flask equipped with a PTFE-coated magnetic stir bar was charged with 4iodobenzoic acid (1.2401 g, $5.0 \mathrm{mmol}, 1 \mathrm{eq}$.). Methanol was added at room temperature, followed by concentrated sulfuric acid ( 1 drop per mmol). The solution was stirred at a reflux for $12 \mathrm{~h}$. The solution was cooled to room temperature. Upon cooling to room temperature, the solution was agitated briefly using a glass pipette tip to induce crystallization. The mixture was filtered by suction and the precipitate was washed three times with a small amount of pentanes. The solid was collected and dried under vacuum to obtain I-2a as a white powder ( $779.5 \mathrm{mg}, 59 \%$ yield). The filtrate could be collected, concentrated, and cooled to obtain another $373.9 \mathrm{mg}$ of material (total yield: $1.1534 \mathrm{~g}, 88 \%$ yield). The spectroscopic data matched those reported in the literature. ${ }^{31}$

${ }^{1} \mathbf{H}$ NMR $\left(\mathrm{CDCl}_{3}, 500 \mathrm{MHz}\right): \delta 7.82-7.77(\mathrm{~m}, 1 \mathrm{H}), 7.76-7.72(\mathrm{~m}, 1 \mathrm{H}), 3.90(\mathrm{~s}, 1 \mathrm{H})$

${ }^{13} \mathrm{C}\left\{{ }^{1} \mathrm{H}\right\}$ NMR $\left(\mathrm{CDCl}_{3}, 125 \mathrm{MHz}\right): \delta$ 166.7, 137.8, 131.2, 129.7, 100.9, 52.4
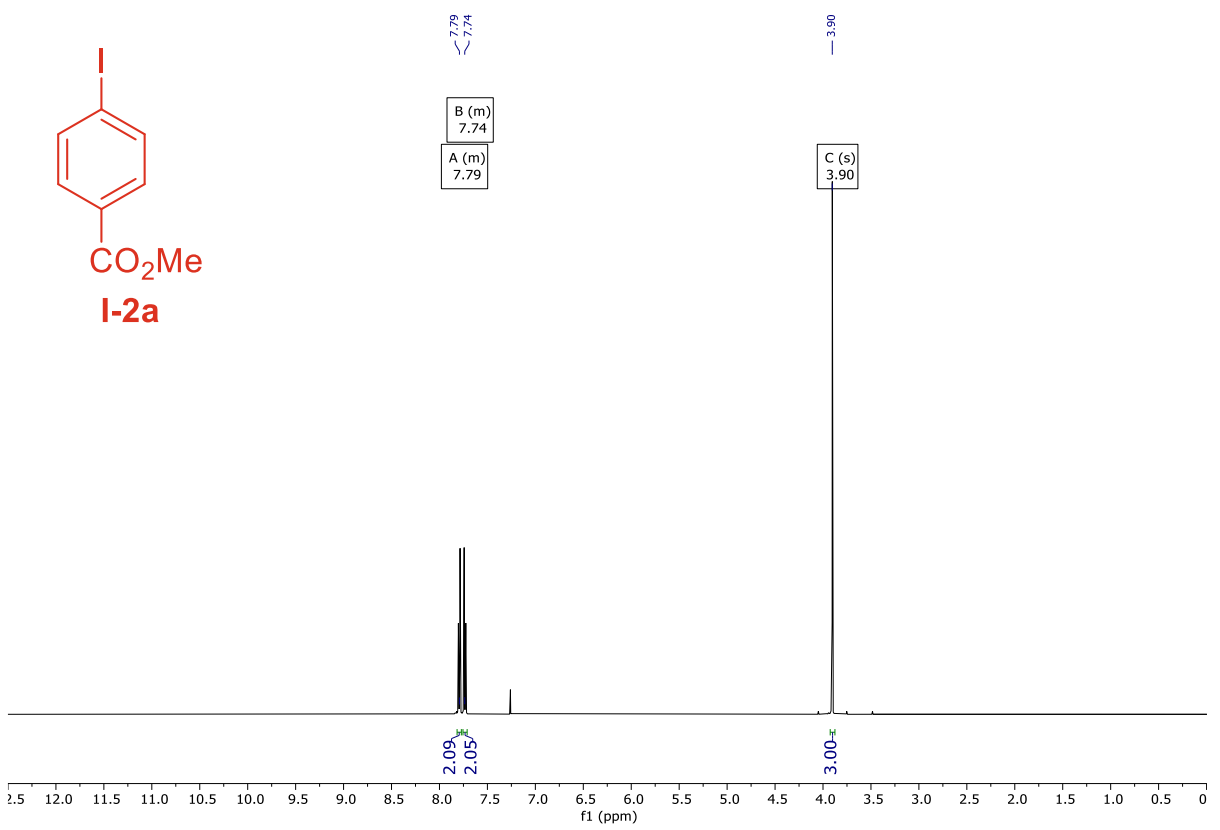


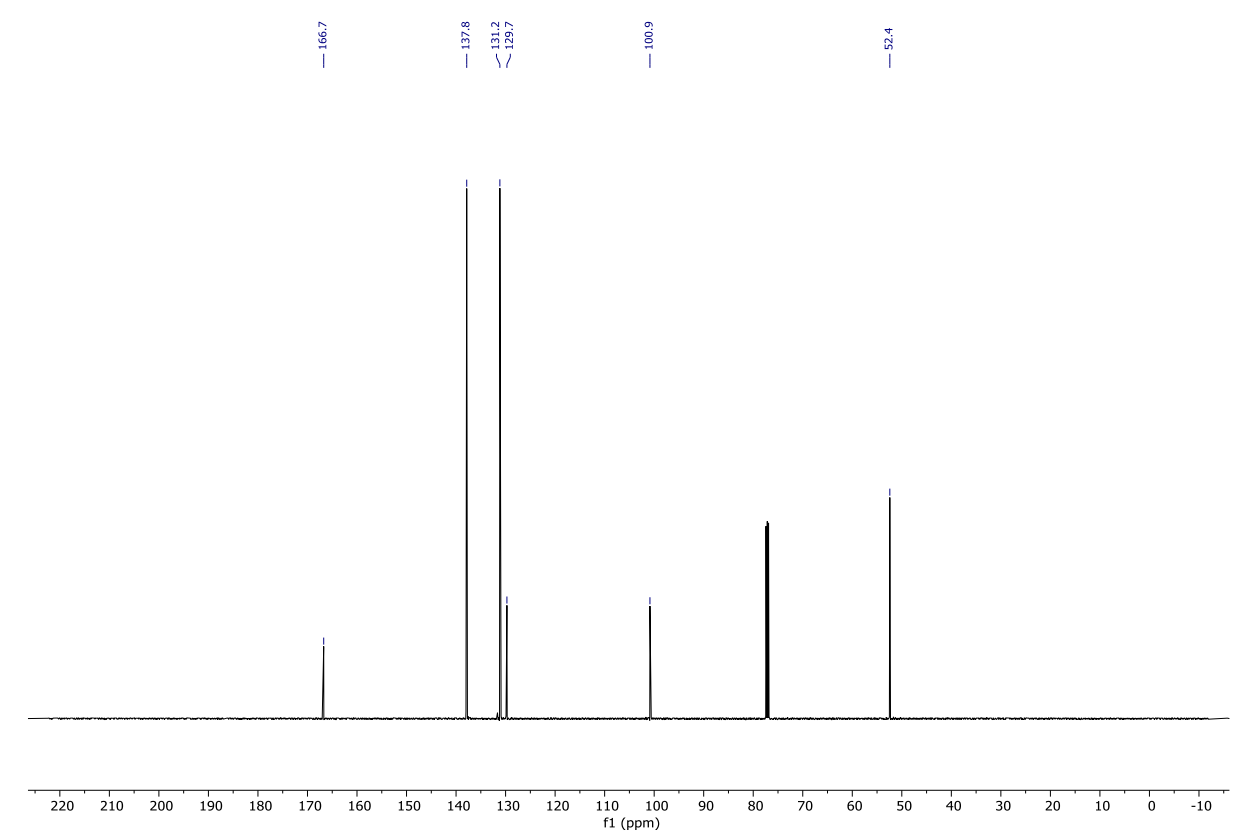

\subsubsection{Procedure for the Reaction using 0.2 eq. I-2a and $\mathrm{NiCl}_{2}(\mathrm{dme})$}<smiles>Cn1c(Cl)nc2ccccc21</smiles>

$1 \mathrm{a}$<smiles>COC(=O)c1ccc(Cl)cc1</smiles>

2a, 1.3 eq.

$$
\begin{gathered}
10 \mathrm{~mol} \% \mathrm{NiCl}_{2} \text { (dme) } \\
15 \mathrm{~mol} \% \text { bipy } \\
2 \text { eq. } \mathrm{Zn}
\end{gathered}
$$

DMF [0.2], $85^{\circ} \mathrm{C}, 24 \mathrm{~h}$ 2 eq. $\mathrm{MgCl}_{2}$

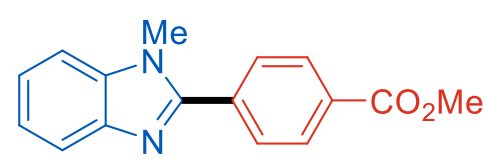

3aa $72 \%$ yield

An oven-dried 2-dram vial was charged with a PTFE-coated stir bar and cooled under a positive pressure of argon. To the vial was added sequentially 1a (33.3 mg, $0.2 \mathrm{mmol}, 1$ eq.), 2a (44.4 mg, 0.26 mmol, 1.3 eq.), I-2a (10.5 mg, 0.04 mmol, 0.2 eq.), NiCl 2 (dme) (4.4 mg, 10 mol\%), 2,2'-bipyridine (4.7 mg, $15 \mathrm{~mol} \%), \mathrm{Zn}$ (26.2 mg, $0.4 \mathrm{mmol}, 2$ eq.), and $\mathrm{MgCl}_{2}$ (38.1 mg, $0.4 \mathrm{mmol}, 2.0$ eq.). The vial was sealed with a screw cap fitted with a PTFE-faced silicone septum and then DMF ( $1 \mathrm{~mL}, 0.2 \mathrm{M}$ relative to 1a) was added at room temperature under an atmosphere of argon. The vial was placed in an oil bath pre-heated to 85 ${ }^{\circ} \mathrm{C}$ and stirred for $24 \mathrm{~h}$.

The reaction mixture was cooled to room temperature and the crude mixture was filtered through a short plug of silica gel, eluting with ethyl acetate. The filtrate was then washed twice with water and twice with brine. The organic layer was then dried over $\mathrm{MgSO}_{4}$ and then filtered over a short plug of silica gel, eluting with ethyl acetate. A known amount of 1,3,5-trimethoxybenzene was added to the crude, and the sample was completely dissolved in $1 \mathrm{~mL}$ of $\mathrm{CDCl}_{3}$. The sample was analyzed by NMR using a 10 second 
relaxation delay. The yields were determined based on the integration of the compounds relative to 1,3,5trimethoxybenzene. $27 \%$ of the homocoupling of $2 \mathrm{a} / \mathrm{I}-\mathbf{2 a}$ was also formed in the reaction.

\subsubsection{Procedure for the Reaction using 1.5 eq. I-2a and $\mathrm{Nil}_{2}$}

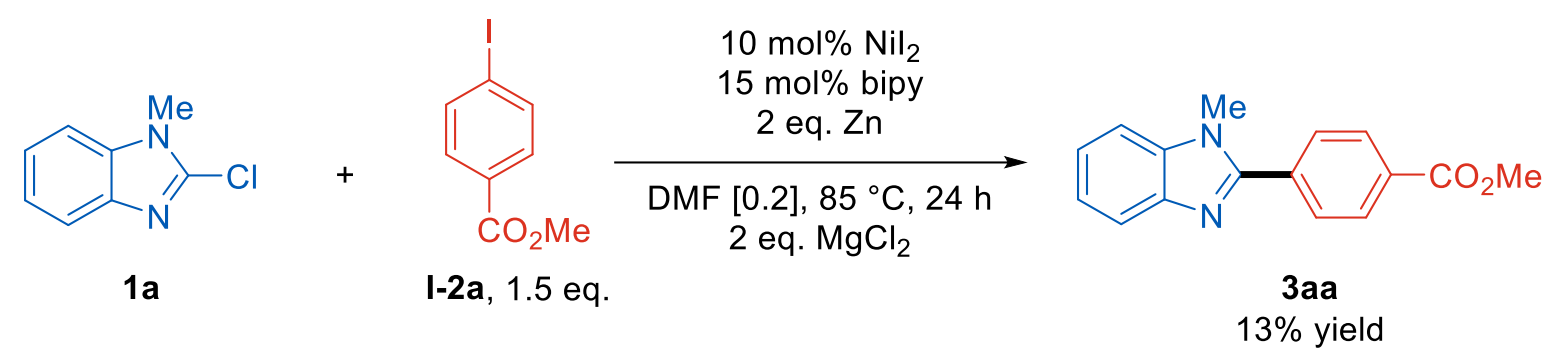

An oven-dried 2-dram vial was charged with a PTFE-coated stir bar and cooled under a positive pressure of argon. To the vial was added sequentially 1 a $(33.3 \mathrm{mg}, 0.2 \mathrm{mmol}, 1 \mathrm{eq}$ )), I-2a (78.6 mg, 0.3 mmol, 1.5 eq.), $\mathrm{Nil}_{2}$ (4.4 mg, 10 mol\%), 2,2'-bipyridine ( $\left.4.7 \mathrm{mg}, 15 \mathrm{~mol} \%\right)$, Zn (26.2 mg, $0.4 \mathrm{mmol}, 2$ eq.), and $\mathrm{MgCl}_{2}$ (38.1 mg, $0.4 \mathrm{mmol}, 2.0$ eq.). The vial was sealed with a screw cap fitted with a PTFE-faced silicone septum and then DMF ( $1 \mathrm{~mL}, 0.2 \mathrm{M}$ relative to $1 \mathrm{a})$ was added at room temperature under an atmosphere of argon. The vial was placed in an oil bath pre-heated to $85^{\circ} \mathrm{C}$ and stirred for $24 \mathrm{~h}$.

The reaction mixture was cooled to room temperature and the crude mixture was filtered through a short plug of silica gel, eluting with ethyl acetate. The filtrate was then washed twice with water and twice with brine. The organic layer was then dried over $\mathrm{MgSO}_{4}$ and then filtered over a short plug of silica gel, eluting with ethyl acetate. A known amount of 1,3,5-trimethoxybenzene was added to the crude, and the sample was completely dissolved in $1 \mathrm{~mL}$ of $\mathrm{CDCl}_{3}$. The sample was analyzed by NMR using a 10 second relaxation delay. The yields were determined based on the integration of the compounds relative to 1,3,5trimethoxybenzene.

These results, in combination with the results from section 5.5.4 led us to consider the possibility that $\mathbf{I - 2 a}$ is an intermediate in the reaction. Large concentrations of $\mathbf{I - 2 a}$ could be detrimental for reaction success, but steady-state concentrations could facilitate the reaction. Unfortunately, we did not observe the formation of I-2a in the reaction using NMR spectroscopy. This does not conclude that I-2a is not an intermediate as it can be formed and consumed at a rate faster than the NMR timescale.

\subsubsection{Procedure for Halide Exchange Experiments with 1a using $\mathbf{M g l}_{2}$}

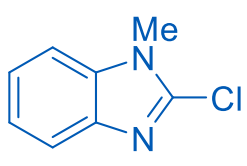

$1 \mathrm{a}$

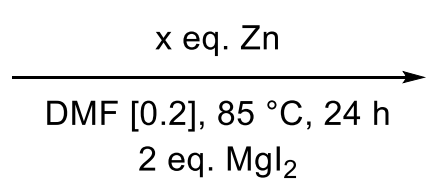

$$
\text { I-1a } x=0,0 \% \text { yield, } 83 \%
$$

if $x=0,0 \%$ yield, $83 \%$ recovered $1 \mathrm{a}$

if $x=2,0 \%$ yield, $34 \%$ recovered $1 \mathrm{a}$

An oven-dried 2-dram vial was charged with a PTFE-coated stir bar and cooled under a positive pressure of argon. To the vial was added sequentially $1 \mathrm{a}(33.3 \mathrm{mg}, 0.2 \mathrm{mmol}, 1 \mathrm{eq}$.), $\mathrm{Zn}$ (either 0 eq. or $26.2 \mathrm{mg}, 0.4 \mathrm{mmol}, 2$ eq.), and $\mathrm{MgI}_{2}$ (111.2 mg, $0.4 \mathrm{mmol}, 2$ eq.). The vial was sealed with a screw cap fitted with a PTFE-faced silicone septum and then DMF (1 mL, $0.2 \mathrm{M}$ relative to $1 \mathrm{a})$ was added at room 
temperature under an atmosphere of argon. The vial was placed in an oil bath pre-heated to $85{ }^{\circ} \mathrm{C}$ and stirred for $24 \mathrm{~h}$.

The reaction mixture was cooled to room temperature and the crude mixture was filtered through a short plug of silica gel, eluting with ethyl acetate. The filtrate was then washed twice with water and twice with brine. The organic layer was then dried over $\mathrm{MgSO}_{4}$ and then filtered over a short plug of silica gel, eluting with ethyl acetate. A known amount of 1,3,5-trimethoxybenzene was added to the crude, and the sample was completely dissolved in $1 \mathrm{~mL}$ of $\mathrm{CDCl}_{3}$. The sample was analyzed by ASAP-MS using an APCI ionization source and by NMR. The sample was analyzed by NMR using a 10 second relaxation delay. The yields were determined based on the integration of the compounds relative to 1,3,5-trimethoxybenzene.

\subsubsection{Procedure for Halide Exchange Experiments with 1a using $\mathrm{ZnI}_{2}$}

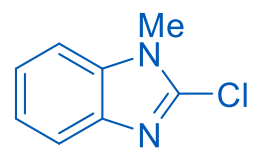

$1 a$

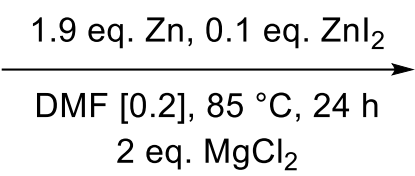

$$
2 \text { eq. } \mathrm{MgCl}_{2}
$$<smiles>Cn1c(I)nc2ccccc21</smiles>

I-1a

$0 \%$ yield

$69 \%$ recovered $1 \mathrm{a}$

An oven-dried 2-dram vial was charged with a PTFE-coated stir bar and cooled under a positive pressure of argon. To the vial was added sequentially $1 \mathrm{a}(33.3 \mathrm{mg}, 0.2 \mathrm{mmol}, 1 \mathrm{eq}$.), Zn (24.8 mg, 0.38 mmol, 1.9 eq.), $\mathrm{ZnI}_{2}$ (6.4 mg, $0.02 \mathrm{mmol}, 0.1$ eq.), and $\mathrm{MgCl}_{2}$ (38.1 mg, $0.4 \mathrm{mmol}, 2$ eq.). The vial was sealed with a screw cap fitted with a PTFE-faced silicone septum and then DMF ( $1 \mathrm{~mL}, 0.2 \mathrm{M}$ relative to 1a) was added at room temperature under an atmosphere of argon. The vial was placed in an oil bath pre-heated to $85^{\circ} \mathrm{C}$ and stirred for $24 \mathrm{~h}$.

The reaction mixture was cooled to room temperature and the crude mixture was filtered through a short plug of silica gel, eluting with ethyl acetate. The filtrate was then washed twice with water and twice with brine. The organic layer was then dried over $\mathrm{MgSO}_{4}$ and then filtered over a short plug of silica gel, eluting with ethyl acetate. A known amount of 1,3,5-trimethoxybenzene was added to the crude, and the sample was completely dissolved in $1 \mathrm{~mL}$ of $\mathrm{CDCl}_{3}$. The sample was analyzed by ASAP-MS using an APCI ionization source and by NMR. The sample was analyzed by NMR using a 10 second relaxation delay. The yields were determined based on the integration of the compounds relative to 1,3,5-trimethoxybenzene.

\subsubsection{Procedure for Halide Exchange Experiments with $2 \mathrm{a}$ using $\mathbf{M g I}_{2}$}

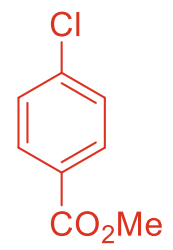

$2 a$

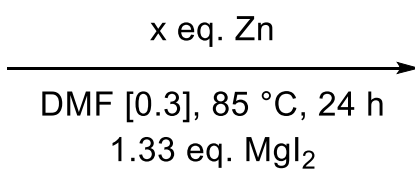

if $x=0,0 \%$ yield, $80 \%$ recovered $2 \mathrm{a}$

if $x=1.33,0 \%$ yield, $74 \%$ recovered $2 a$ 
An oven-dried 2-dram vial was charged with a PTFE-coated stir bar and cooled under a positive pressure of argon. To the vial was added sequentially $2 \mathrm{a}(51.2 \mathrm{mg}, 0.3 \mathrm{mmol}, 1$ eq.), Zn (either 0 eq. or $26.2 \mathrm{mg}, 0.40 \mathrm{mmol}, 1.27$ eq.), and $\mathrm{Mgl}_{2}$ (111.2 mg, $0.4 \mathrm{mmol}, 1.33$ eq.). The vial was sealed with a screw cap fitted with a PTFE-faced silicone septum and then DMF ( $1 \mathrm{~mL}, 0.3 \mathrm{M}$ relative to $2 \mathrm{a}$ ) was added at room temperature under an atmosphere of argon. The vial was placed in an oil bath pre-heated to $85{ }^{\circ} \mathrm{C}$ and stirred for $24 \mathrm{~h}$.

The reaction mixture was cooled to room temperature and the crude mixture was filtered through a short plug of silica gel, eluting with ethyl acetate. The filtrate was then washed twice with water and twice with brine. The organic layer was then dried over $\mathrm{MgSO}_{4}$ and then filtered over a short plug of silica gel, eluting with ethyl acetate. A known amount of 1,3,5-trimethoxybenzene was added to the crude, and the sample was completely dissolved in $1 \mathrm{~mL}$ of $\mathrm{CDCl}_{3}$. The sample was analyzed by ASAP-MS using an APCI ionization source and by NMR. The sample was analyzed by NMR using a 10 second relaxation delay. The yields were determined based on the integration of the compounds relative to 1,3,5-trimethoxybenzene.

\subsubsection{Procedure for Halide Exchange Experiments with $2 \mathrm{a}$ using $\mathrm{ZnI}_{2}$}

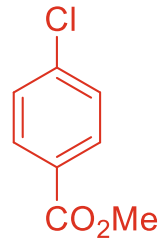

$2 a$
1.27 eq. $\mathrm{Zn}, 0.067$ eq. $\mathrm{Znl}_{2}$

DMF [0.3], $85^{\circ} \mathrm{C}, 24 \mathrm{~h}$

1.33 eq. $\mathrm{MgCl}_{2}$

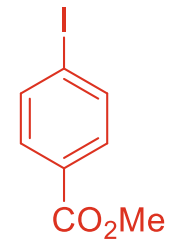

I-2a

$75 \%$ recovered $\mathbf{2 a}$

An oven-dried 2-dram vial was charged with a PTFE-coated stir bar and cooled under a positive pressure of argon. To the vial was added sequentially $2 \mathrm{a}(51.2 \mathrm{mg}, 0.3 \mathrm{mmol}, 1 \mathrm{eq}$.), Zn (24.8 mg, 0.38 mmol, 1.27 eq.), $\mathrm{ZnI}_{2}$ (6.4 mg, $0.02 \mathrm{mmol}, 0.067$ eq.), and $\mathrm{MgCl}_{2}$ (38.1 mg, $0.4 \mathrm{mmol}, 2$ eq.). The vial was sealed with a screw cap fitted with a PTFE-faced silicone septum and then DMF ( $1 \mathrm{~mL}, 0.3 \mathrm{M}$ relative to 2a) was added at room temperature under an atmosphere of argon. The vial was placed in an oil bath preheated to $85^{\circ} \mathrm{C}$ and stirred for $24 \mathrm{~h}$.

The reaction mixture was cooled to room temperature and the crude mixture was filtered through a short plug of silica gel, eluting with ethyl acetate. The filtrate was then washed twice with water and twice with brine. The organic layer was then dried over $\mathrm{MgSO}_{4}$ and then filtered over a short plug of silica gel, eluting with ethyl acetate. A known amount of 1,3,5-trimethoxybenzene was added to the crude, and the sample was completely dissolved in $1 \mathrm{~mL}$ of $\mathrm{CDCl}_{3}$. The sample was analyzed by ASAP-MS using an APCI ionization source and by NMR. The sample was analyzed by NMR using a 10 second relaxation delay. The yields were determined based on the integration of the compounds relative to 1,3,5-trimethoxybenzene.

\subsection{Stoichiometric Reactions using in situ Generated Nickel Complexes}

Scheme S11. Stoichiometric reactions of $1 \mathbf{a}$ and $\mathbf{2 a}$ with the $\mathrm{Nil}_{2}$ pre-catalyst 


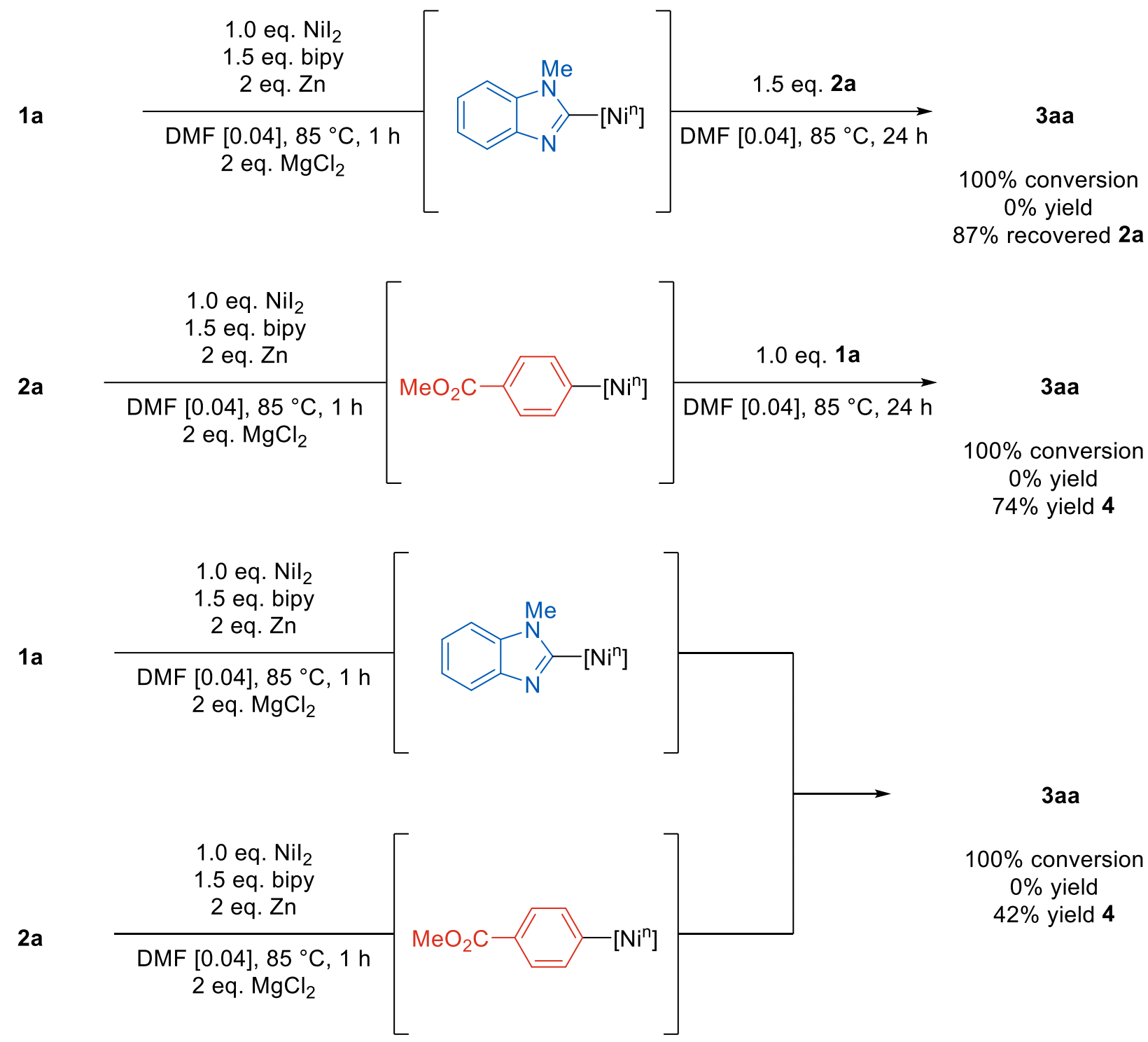

Scheme S12. Stoichiometric reactions of $1 \mathbf{a}$ and $2 \mathrm{a}$ with the $\mathrm{NiCl}_{2}(\mathrm{dme})$ pre-catalyst

$1 a$

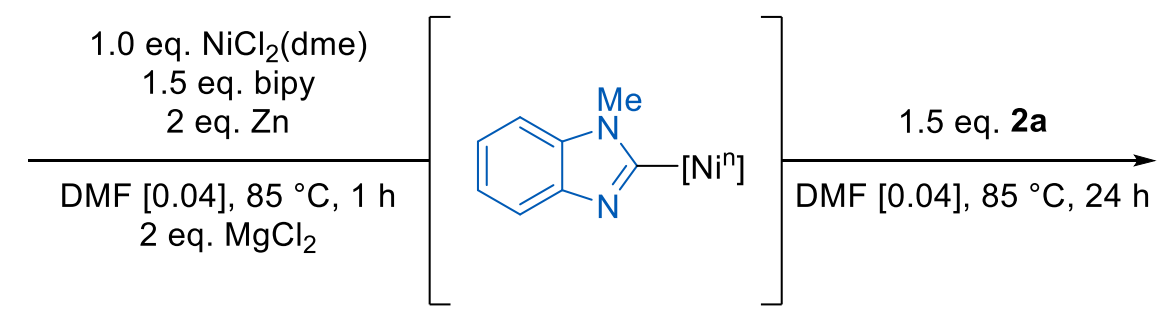

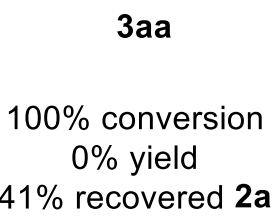

3aa

$0 \%$ yield $41 \%$ recovered $\mathbf{2 a}$ 


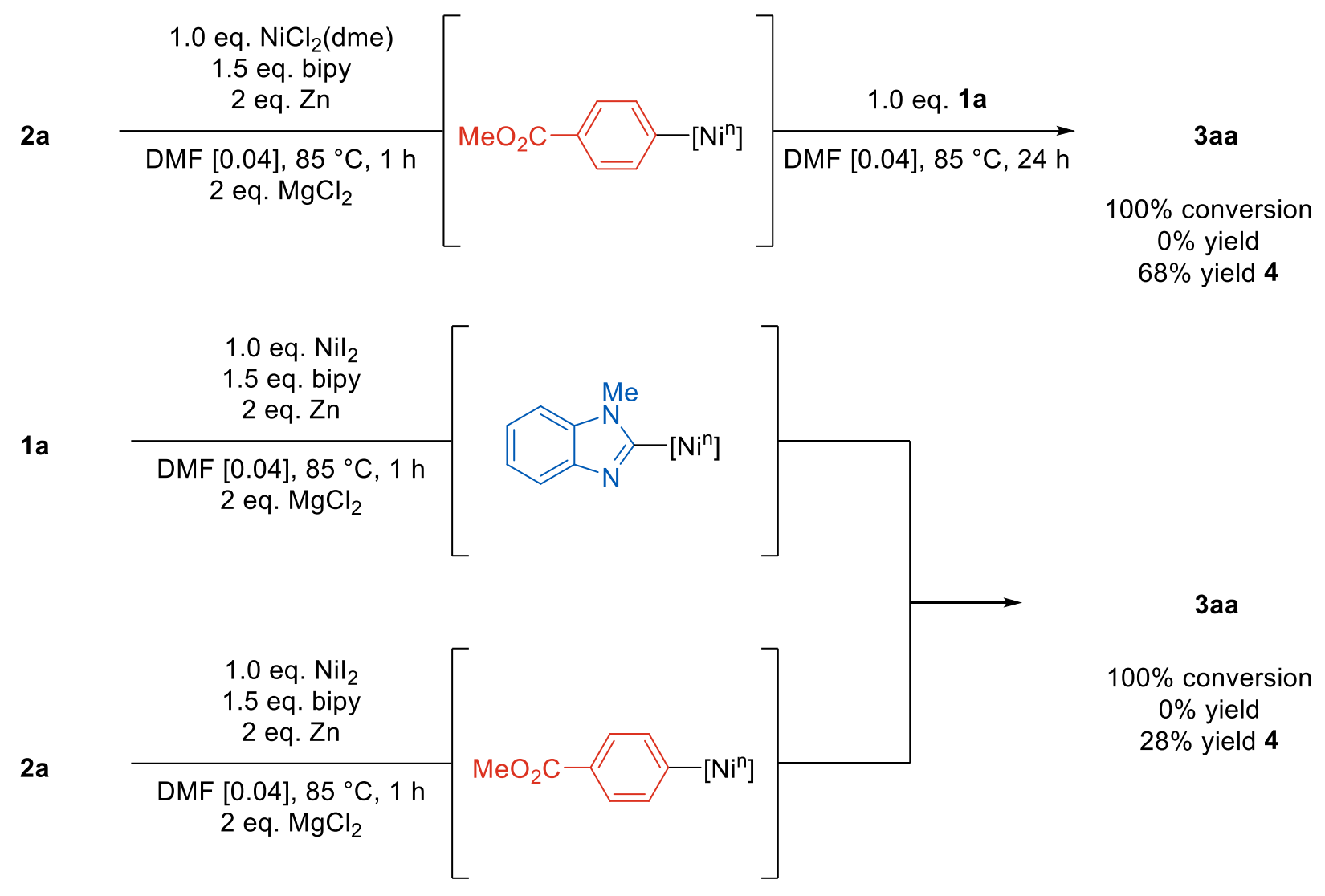

\subsubsection{Procedure for the Reaction of 1a with Stoichiometric Nickel}

An oven-dried 2-dram vial was charged with a PTFE-coated stir bar and cooled under a positive pressure of argon. To the vial was added sequentially $1 \mathrm{a}(3.3 \mathrm{mg}, 0.02 \mathrm{mmol}, 1 \mathrm{eq}$ ), Nil 2 (6.3 mg, 0.02 mmol, 1 eq.) or $\mathrm{NiCl}_{2}$ (dme) ( $4.4 \mathrm{mg}, 0.02 \mathrm{mmol}, 1$ eq.), 2,2'-bipyridine ( $4.7 \mathrm{mg}, 0.03 \mathrm{mmol}, 1.5 \mathrm{eq}$.), $\mathrm{Zn}$ (2.6 $\mathrm{mg}, 0.04 \mathrm{mmol}, 2$ eq.), and $\mathrm{MgCl}_{2}$ (3.8 $\mathrm{mg}, 0.04 \mathrm{mmol}, 2$ eq.). The vial was sealed with a screw cap fitted with a PTFE-faced silicone septum and then DMF $(0.5 \mathrm{~mL}, 0.04 \mathrm{M}$ relative to 1a) was added at room temperature under an atmosphere of argon. The vial was placed in an oil bath pre-heated to $85{ }^{\circ} \mathrm{C}$ and stirred for $1 \mathrm{~h}$. After $1 \mathrm{~h}, \mathbf{2 a}$ ( $5.1 \mathrm{mg}, 0.03 \mathrm{mmol}, 1.5 \mathrm{eq}$.) was added as a solution in $0.5 \mathrm{~mL} \mathrm{DMF} \mathrm{(0.04} \mathrm{M}$ relative to 1a). The final concentration of the reaction is $0.02 \mathrm{M}$ relative to $1 \mathrm{a}$. This concentration was chosen to mimic the concentration of the nickel catalyst in the standard reaction.

The reaction mixture was cooled to room temperature and the crude mixture was filtered through a short plug of silica gel, eluting with ethyl acetate. The filtrate was then washed twice with water and twice with brine. The organic layer was then dried over $\mathrm{MgSO}_{4}$ and then filtered over a short plug of silica gel, eluting with ethyl acetate. A known amount of 1,3,5-trimethoxybenzene was added to the crude, and the sample was completely dissolved in $1 \mathrm{~mL}$ of $\mathrm{CDCl}_{3}$. The sample was analyzed by NMR using a 10 second relaxation delay. The yields were determined based on the integration of the compounds relative to $1,3,5-$ trimethoxybenzene. 


\subsubsection{Procedure for the Reaction of 2a with Stoichiometric Nickel}

An oven-dried 2-dram vial was charged with a PTFE-coated stir bar and cooled under a positive pressure of argon. To the vial was added sequentially $2 \mathrm{a}(3.4 \mathrm{mg}, 0.02 \mathrm{mmol}, 1$ eq.), Nil 2 (6.3 $\mathrm{mg}, 0.02$ mmol, 1 eq.) or $\mathrm{NiCl}_{2}$ (dme) (4.4 mg, $0.02 \mathrm{mmol}, 1$ eq.), 2,2'-bipyridine ( $4.7 \mathrm{mg}, 0.03 \mathrm{mmol}, 1.5$ eq.), Zn (2.6 $\mathrm{mg}, 0.04 \mathrm{mmol}, 2$ eq.), and $\mathrm{MgCl}_{2}(3.8 \mathrm{mg}, 0.04 \mathrm{mmol}, 2$ eq.). The vial was sealed with a screw cap fitted with a PTFE-faced silicone septum and then DMF $(0.5 \mathrm{~mL}, 0.04 \mathrm{M}$ relative to $2 \mathrm{a})$ was added at room temperature under an atmosphere of argon. The vial was placed in an oil bath pre-heated to $85{ }^{\circ} \mathrm{C}$ and stirred for $1 \mathrm{~h}$. After $1 \mathrm{~h}, 1 \mathrm{a}$ ( $3.3 \mathrm{mg}, 0.02 \mathrm{mmol}, 1.0 \mathrm{eq}$.) was added as a solution in $0.5 \mathrm{~mL}$ DMF (0.04 M relative to $\mathbf{2 a}$ ). The final concentration of the reaction is $0.02 \mathrm{M}$ relative to $2 \mathrm{a}$. This concentration was chosen to mimic the concentration of the nickel catalyst in the standard reaction.

The reaction mixture was cooled to room temperature and the crude mixture was filtered through a short plug of silica gel, eluting with ethyl acetate. The filtrate was then washed twice with water and twice with brine. The organic layer was then dried over $\mathrm{MgSO}_{4}$ and then filtered over a short plug of silica gel, eluting with ethyl acetate. A known amount of 1,3,5-trimethoxybenzene was added to the crude, and the sample was completely dissolved in $1 \mathrm{~mL}$ of $\mathrm{CDCl}_{3}$. The sample was analyzed by NMR using a 10 second relaxation delay. The yields were determined based on the integration of the compounds relative to 1,3,5trimethoxybenzene.

\subsubsection{Procedure for the Reaction of 1a and 2a with Stoichiometric Nickel}

An oven-dried 2-dram vial was charged with a PTFE-coated stir bar and cooled under a positive pressure of argon. To the vial was added sequentially $1 \mathrm{a}(3.3 \mathrm{mg}, 0.02 \mathrm{mmol}, 1 \mathrm{eq}$.), Nil 2 (6.3 mg, 0.02 mmol, 1 eq.) or $\mathrm{NiCl}_{2}$ (dme) ( $4.4 \mathrm{mg}, 0.02 \mathrm{mmol}, 1$ eq.), 2,2'-bipyridine ( $4.7 \mathrm{mg}, 0.03 \mathrm{mmol}, 1.5$ eq.), Zn (2.6 $\mathrm{mg}, 0.04 \mathrm{mmol}, 2$ eq.), and $\mathrm{MgCl}_{2}$ (3.8 $\mathrm{mg}, 0.04 \mathrm{mmol}, 2$ eq.). The vial was sealed with a screw cap fitted with a PTFE-faced silicone septum and then DMF $(0.5 \mathrm{~mL}, 0.04 \mathrm{M}$ relative to $1 \mathrm{a})$ was added at room temperature under an atmosphere of argon. The vial was placed in an oil bath pre-heated to $85{ }^{\circ} \mathrm{C}$ and stirred for $1 \mathrm{~h}$.

A separate oven-dried 2-dram vial was charged with a PTFE-coated stir bar and cooled under a positive pressure of argon. To the vial was added sequentially $2 \mathrm{a}\left(3.4 \mathrm{mg}, 0.02 \mathrm{mmol}, 1 \mathrm{eq}\right.$.), $\mathrm{Nil}_{2}(6.3 \mathrm{mg}$, $0.02 \mathrm{mmol}, 1$ eq.) or $\mathrm{NiCl}_{2}$ (dme) (4.4 mg, $0.02 \mathrm{mmol}, 1$ eq.), 2,2'-bipyridine ( $4.7 \mathrm{mg}, 0.03 \mathrm{mmol}, 1.5$ eq.), $\mathrm{Zn}\left(2.6 \mathrm{mg}, 0.04 \mathrm{mmol}, 2\right.$ eq.), and $\mathrm{MgCl}_{2}$ (3.8 mg, $0.04 \mathrm{mmol}, 2$ eq.). The vial was sealed with a screw cap fitted with a PTFE-faced silicone septum and then DMF $(0.5 \mathrm{~mL}, 0.04 \mathrm{M}$ relative to $2 \mathrm{a})$ was added at room temperature under an atmosphere of argon. The vial was placed in an oil bath pre-heated to $85^{\circ} \mathrm{C}$ and stirred for $1 \mathrm{~h}$.

After $1 \mathrm{~h}$, the solution containing the $\mathbf{2 a}$ /nickel mixture was added to the solution containing the $1 \mathrm{a} /$ nickel mixture via syringe. The resulting solution was stirred at $85^{\circ} \mathrm{C}$ for $24 \mathrm{~h}$.

The reaction mixture was cooled to room temperature and the crude mixture was filtered through a short plug of silica gel, eluting with ethyl acetate. The filtrate was then washed twice with water and twice with brine. The organic layer was then dried over $\mathrm{MgSO}_{4}$ and then filtered over a short plug of silica gel, eluting with ethyl acetate. A known amount of 1,3,5-trimethoxybenzene was added to the crude, and the sample was completely dissolved in $1 \mathrm{~mL}$ of $\mathrm{CDCl}_{3}$. The sample was analyzed by NMR using a 10 second 
relaxation delay. The yields were determined based on the integration of the compounds relative to $1,3,5-$ trimethoxybenzene.

\subsection{Discussion about the role of $\mathrm{MgCl}_{2}$}

The inclusion of salt additives to increase reaction efficiency in nickel-catalyzed cross-electrophile coupling reactions is not new but is not often well-understood. Important contributions from the Weix, and Wang and Gong groups have begun to shed light on the effects of some of these additives. ${ }^{32,33}$ The role of $\mathrm{LiCl}$ has been shown to assist in the reduction of $\mathrm{Ni}^{11}$ to $\mathrm{Ni}^{0}$ in the multimetallic cross-coupling of aryl chlorides with aryl triflates. ${ }^{32}$ Furthermore, $\mathrm{LiCl}$ offset the inhibition in the reduction at $\mathrm{Zn}^{0}$ by in situ formed $\mathrm{Zn}$ " salts. This effect was shown to be coupled with a cation effect as other chloride-containing additives, such as $\mathrm{ZnCl}_{2}, \mathrm{TMSCl}$, or $\mathrm{Bu}_{4} \mathrm{NCl}$ resulted in poor reaction efficiency. The Diao group has also shown that $\mathrm{Ni}^{\prime \prime}$ complexes bearing $\mathrm{N}, \mathrm{N}$ ligands, such as phenanthroline, are unable to be reduced to $\mathrm{Ni}^{0}$ in the presence of $\mathrm{Zn}^{0}$ alone. ${ }^{34}$ Instead, quantitative conversion of the ligated $\mathrm{Ni}$ " complex to a paramagnetic $\mathrm{Ni}^{1}$ species was observed. The authors note that related work by Wang and Gong ${ }^{33}$ identified that the $\mathrm{Ni}^{\prime l}$ species could be reduced to $\mathrm{Ni}^{0}$ in the presence of a magnesium salt. Since the current methodology benefits greatly from the inclusion of at least 2 equivalents of $\mathrm{MgCl}_{2}$ (or $\mathrm{Mgl}_{2}$ ), the rest of this discussion will assess the current effects of these salts in nickel-catalyzed reductive cross-coupling reactions.

Scheme S13. Nickel-catalyzed cross-electrophile coupling of electron-rich aryl iodides with tertiary alkyl bromides. The reaction requires the inclusion of $\mathrm{MgCl}_{2}$ and $\mathrm{LiCl}$ as additives.

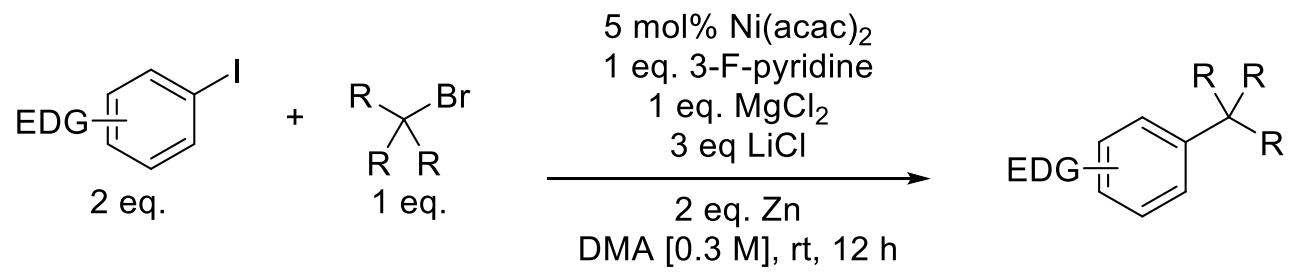

The groups of Wang and Gong reported a cross-electrophile coupling reaction of electron-rich aryl iodides with tertiary alkyl halides (Scheme S13). Their method required the use of both $\mathrm{LiCl}_{\text {and }} \mathrm{MgCl}_{2}$ as additives to enable the coupling. Stoichiometric studies using a [(DMAP) $\left.{ }_{3} \mathrm{Ni}^{\prime \prime} \mathrm{Ar}\right]^{+} \mathrm{X}^{-}$ion pair revealed that the complex was unable to engage the alkyl bromide in the absence of $\mathrm{MgCl}_{2}$ when $\mathrm{X}=\mathrm{I}$. Quantitative conversion of [(DMAP $\left.)_{3} \mathrm{Ni}^{\prime \prime} \mathrm{Ar}\right]^{+} \mathrm{I}^{-}$to $\left[(\mathrm{DMAP})_{3} \mathrm{Ni}^{\prime \prime} \mathrm{Ar}\right]^{+} \mathrm{Cl}^{-}$was observed within 10 minutes. Our methodology does not make use of aryl iodides and so the role of $\mathrm{MgCl}_{2}$ as a chloride source to ensure formation of a (ligand) $\mathrm{nNi}_{\mathrm{N}} \mathrm{Cl}$ species to participate in the reaction is unlikely. Furthermore, we noticed a significant improvement in reaction efficiency when some amount of iodide was present in solution, regardless of how it was added.

Interestingly, Wang and Gong noticed that the $\mathrm{MgCl}_{2}$ additive could be capable of enhancing the efficiency of their reaction in numerous other ways: (1) $\mathrm{MgCl}_{2}$, as well as $\mathrm{LiCl}$, were both found to activate the $\mathrm{Zn}^{0}$ reductant, ${ }^{35}$ (2) $\mathrm{MgCl}_{2}$ reacted with their catalyst to form a more soluble Ni complex, and (3) their (DMAP) ${ }_{2} \mathrm{Ni}(\text { acac })_{2}$ precatalyst was incapable of being reduced to $\mathrm{Ni}^{0}$ in the absence of $\mathrm{MgCl}_{2}$. In Wang and Gong's report, $\mathrm{MgCl}_{2}$ formed a more soluble $\mathrm{Ni}$ complex presumably due to the removal of acac from $\mathrm{Ni}(\mathrm{acac})_{2}$ via a $\mathrm{Mg}(\mathrm{acac}) \mathrm{X}(\mathrm{X}=\mathrm{Cl}$ or acac) species. We do not add acac to our reaction and so this is unlikely. It is possible that our methodology benefits from the use of $\mathrm{MgCl}_{2}$ as an additive that either activates the $\mathrm{Zn}^{0}$ surface or enables reduction of $\mathrm{Ni}^{1}$ to $\mathrm{Ni}^{0}$, or both. 
Reaction monitoring confirmed that the presence of $\mathrm{MgCl}_{2}$ enables the reaction to proceed efficiently (vide infra, Figure S1). In the absence of $\mathrm{MgCl}_{2}$, the reaction was comparatively slower and displayed an induction period where no product was formed and no starting materials were consumed (Figure S1). Since the starting materials are unstable to the reaction conditions, the inclusion of $\mathrm{MgCl}_{2}$ is indispensable since it allows the reaction to occur much more rapidly. We note that we did not observe the starting materials decompose during the first 8 minutes of the reaction. Based on these results, the we believe that the $\mathrm{MgCl}_{2}$ assists in the reduction of the initial $\mathrm{Ni}^{\text {il }}$ species to form the active $\mathrm{Ni}^{0}$ catalyst.

An alternative role of $\mathrm{MgCl}_{2}$ in nickel-catalyzed $\mathrm{CO}_{2}$ insertion methodologies suggests that the salt might accelerate one-electron reduction via anion-exchange mechanisms. ${ }^{36}$ This is unlikely to occur in our methodology since the anion-exchange that is proposed converts the formed $\left(\mathrm{RCO}_{2}\right)_{2} \mathrm{Zn}$ species to a $\left(\mathrm{RCO}_{2}\right)_{2} \mathrm{Mg}$ species. Mechanistically, there is no product- $\mathrm{Zn}$ " complex that forms and so this metathesis is not possible. Important to our methodology, the authors of the aforementioned study suggest that $\mathrm{MgCl}_{2}$ is likely not participating in the oxidative addition step.

\subsubsection{Reaction Monitoring Studies}

2 scintillation vials charged with a PTFE-coated stir bar were flame-dried and cooled under a positive pressure of argon. To one vial was added sequentially 1a $(233.2 \mathrm{mg}$ ) and $1 \mathbf{a}(358.2 \mathrm{mg})$. DMF (3.5 mL) was added and the mixture was stirred until all of the solids were dissolved to make a substrate stock solution. To the other vial was added sequentially $\mathrm{Ni}_{2}(43.8 \mathrm{mg})$ and bipy $(32.8 \mathrm{mg})$. DMF $(3.5 \mathrm{~mL})$ was added and the mixture was stirred vigorously until all of the solids were dissolved to make a catalyst stock solution.

10 oven-dried 2-dram vials charged with a PTFE-coated stir bar were cooled under a positive pressure of argon. $\mathrm{Zn}$ (13.1 mg, $0.2 \mathrm{mmol}, 2$ eq.) and $\mathrm{MgCl}_{2}$ (19.0 mg, $0.2 \mathrm{mmol}, 2$ eq.) was added to 5 of the vials. To the other 5 vials was added only $\mathrm{Zn}(13.1 \mathrm{mg}, 0.2 \mathrm{mmol}, 2 \mathrm{eq}$.). The vials were sealed with a screw cap fitted with a PTFE-faced silicone septum, and then loaded onto a rack. $0.25 \mathrm{~mL}$ of the substrate stock solution was added to each of the 10 vials followed by $0.25 \mathrm{~mL}$ of the catalyst solution (the reaction is performed with $0.1 \mathrm{mmol}$ of $1 \mathrm{a}$ and $2 \mathrm{a}$ with a final reaction volume of $0.5 \mathrm{~mL}$ ). The rack was placed in an oil bath pre-heated to $85^{\circ} \mathrm{C}$ and stirred.

For the vials containing both $\mathrm{Zn}$ and $\mathrm{MgCl}_{2}$, the reactions were quenched by addition of $1 \mathrm{~mL}$ of saturated $\mathrm{NH}_{4} \mathrm{Cl}_{(\mathrm{aq})}$ at $1,2,4,6$, and 8 minutes. For the vials containing only $\mathrm{Zn}$, the reactions were quenched by addition of $1 \mathrm{~mL}$ of saturated $\mathrm{NH}_{4} \mathrm{Cl}($ aq) at $1,2,5,6$, and 8 minutes.

The reaction mixtures were cooled to room temperature and the crude was filtered through a short plug of silica gel, eluting with ethyl acetate. The filtrate was then washed twice with water and twice with brine. The organic layer was then dried over $\mathrm{MgSO}_{4}$ and then filtered over a short plug of silica gel, eluting with ethyl acetate.

$88.0 \mathrm{mg}$ of 1,3,5-trimethoxybenzene was added to a scintillation vial and dissolved in $11.0 \mathrm{~mL}$ of $\mathrm{CDCl}_{3} .1 \mathrm{~mL}$ of this solution was added to each of the crude mixtures. The sample was analyzed by NMR using a 10 second relaxation delay. The yields were determined based on the integration of the compounds relative to 1,3,5-trimethoxybenzene. Notably, we did not notice the formation of I-2a in the NMR during these studies. This does not conclude that $\mathbf{I - 2 a}$ is not an intermediate in the reaction since it could be formed and consumed faster than the NMR timescale.

Figure S1. Reaction monitoring of the nickel-catalyzed cross-electrophile coupling in the presence of $\mathrm{MgCl}_{2}$ 


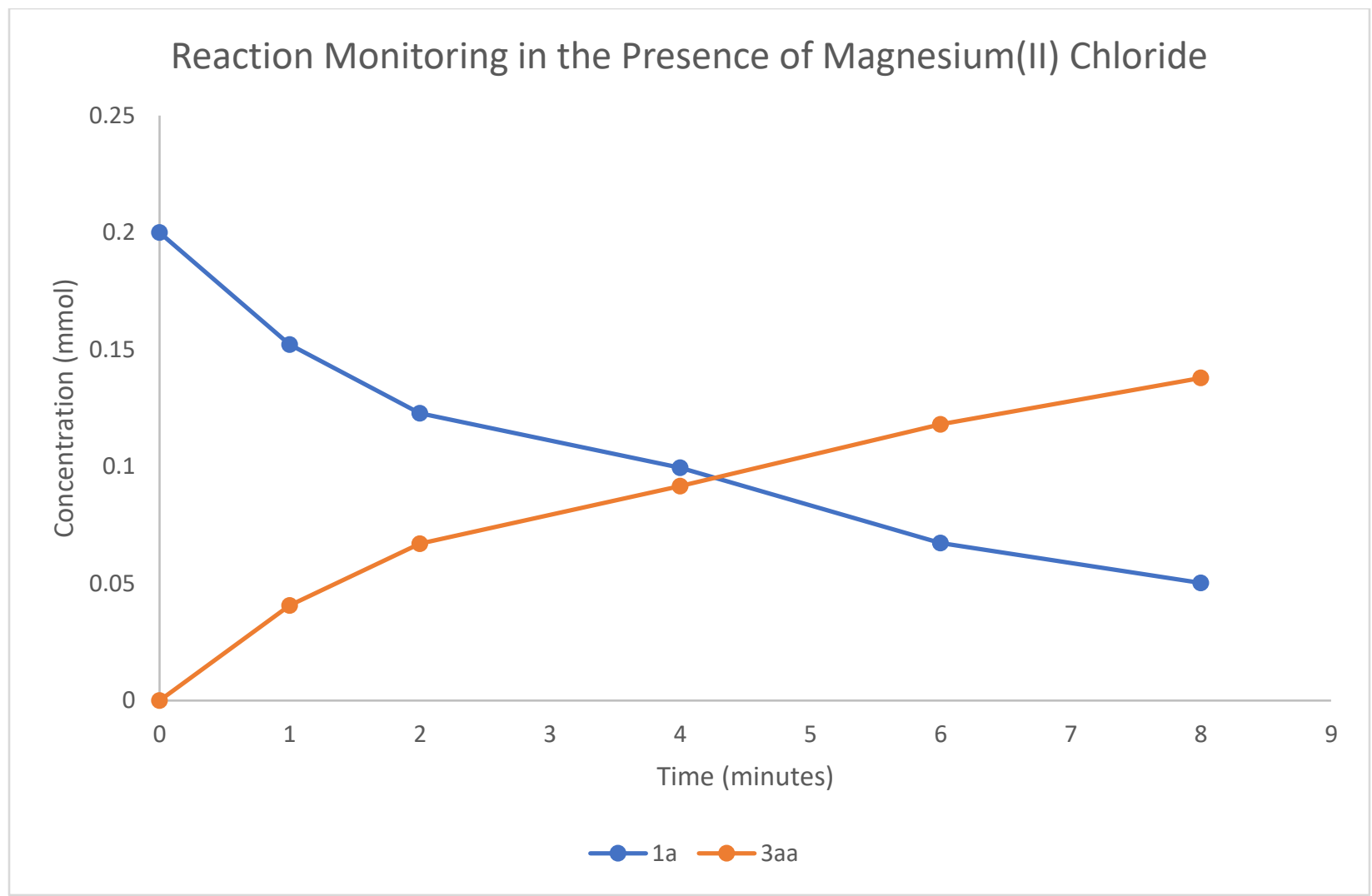

Figure S2. Reaction monitoring of the nickel-catalyzed cross-electrophile coupling in the absence of $\mathrm{MgCl}_{2}$

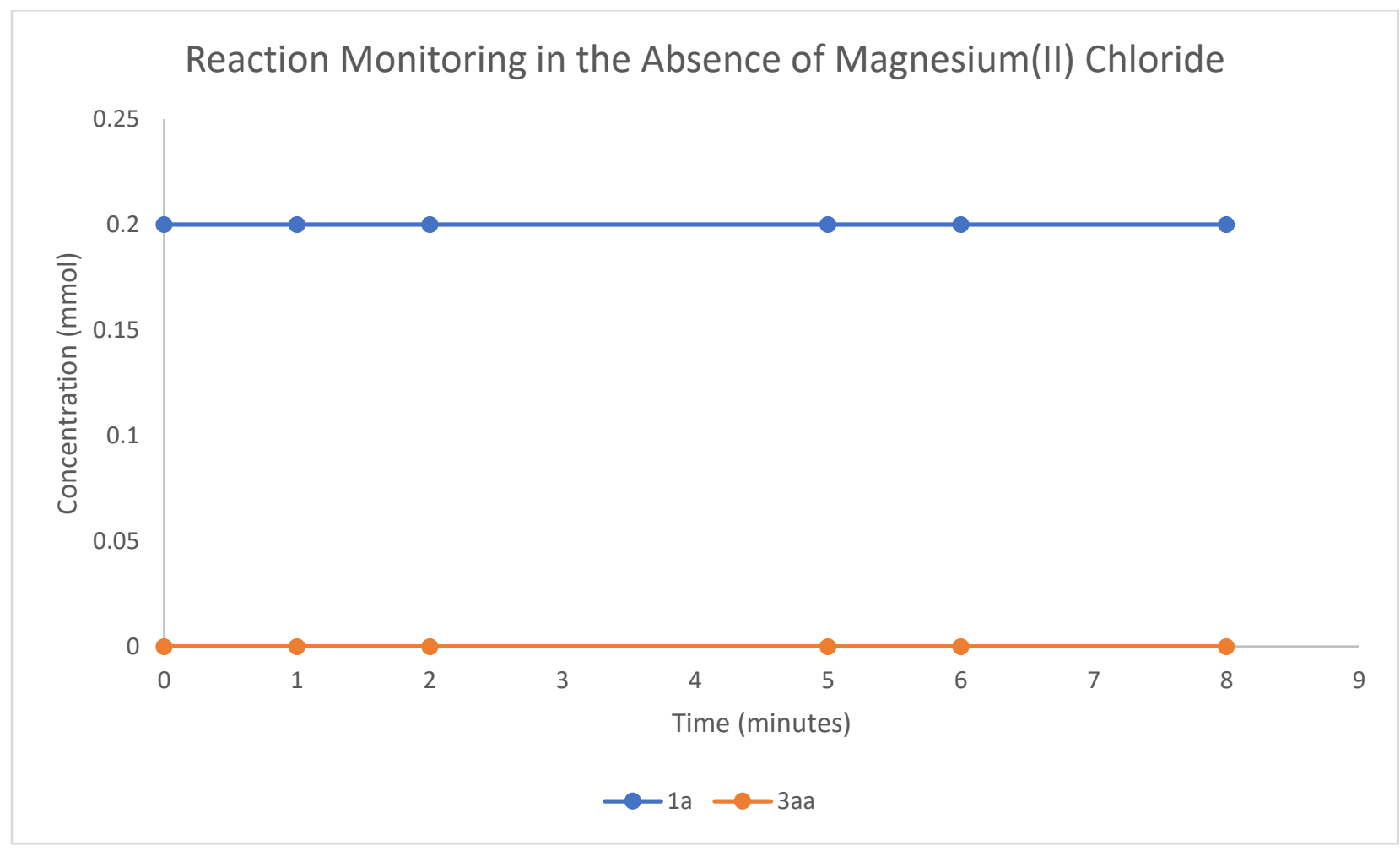




\subsection{Using an Organic Reductant (TDAE) in the Cross-Electrophile Coupling}

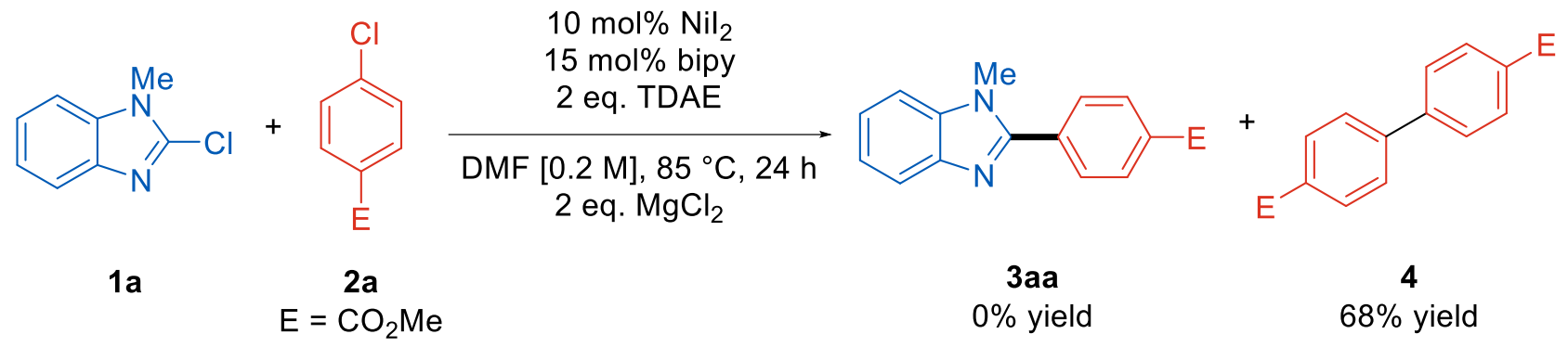

\subsubsection{Procedure for the Cross-Electrophile Coupling using TDAE as the Reductant}

An oven-dried 2-dram vial was charged with a PTFE-coated stir bar and cooled under a positive pressure of argon. To the vial was added sequentially the $1 \mathrm{a}$ ( $33.3 \mathrm{mg}, 0.2 \mathrm{mmol}, 1$ eq.), the $2 \mathrm{a}(51.2 \mathrm{mg}$, $0.3 \mathrm{mmol}, 1.5$ eq.), $\mathrm{Nil}_{2}$ (6.3 mg, $10 \mathrm{~mol} \%$ ), 2,2'-bipyridine (4.7 mg, $15 \mathrm{~mol} \%$ ), and $\mathrm{MgCl}_{2}$ (38.1 mg, 0.4 mmol, 2 eq.). The vial was sealed with a screw cap fitted with a PTFE-faced silicone septum, and then DMF $(1 \mathrm{~mL}, 0.2 \mathrm{M}$ relative to the heteroaryl chloride) was added at room temperature under an atmosphere of argon, followed by addition of TDAE $(93 \mu \mathrm{L}, 0.4 \mathrm{mmol}, 2$ eq. $)$. The argon balloon was removed and the vial was placed in an oil bath pre-heated to $85^{\circ} \mathrm{C}$ and stirred for $24 \mathrm{~h}$.

The reaction mixture was cooled to room temperature and filtered through a short plug of silica gel, eluting with ethyl acetate. The filtrate was then washed twice with water and twice with brine. The organic layer was then dried over $\mathrm{MgSO}_{4}$, and then filtered over a short plug of silica gel, eluting with ethyl acetate. A known amount of 1,3,5-trimethoxybenzene was added to the crude, and the sample was completely dissolved in $1 \mathrm{~mL}$ of $\mathrm{CDCl}_{3}$. The sample was analyzed by NMR using a 10 second relaxation delay. The yields were determined based on the integration of the compounds relative to 1,3,5-trimethoxybenzene.

The reaction produced $0 \%$ yield of the desired product when using TDAE as the reductant, but still formed the homocoupling of $\mathbf{2} \mathbf{a}$ in $68 \%$ yield. While the success of TDAE as the reductant in a crosselectrophile coupling reaction would suggest that the intermediacy of an organozinc or organomanganese is not operative, the failure of the reaction to produce desired product does not suggest that these intermediates are formed. A previous report by Weix ${ }^{37}$ has shown that TDAE can perform worse than metallic reductants in reductive cross-coupling reactions. More recently, Reisman ${ }^{38}$ has demonstrated that TDAE did not deliver product in place of $\mathrm{Mn}$, while having ruled out the intermediacy of organomanganese species.

\subsection{Using a Nickel ${ }^{0}$ Pre-Catalyst in the Cross-Electrophile Coupling}

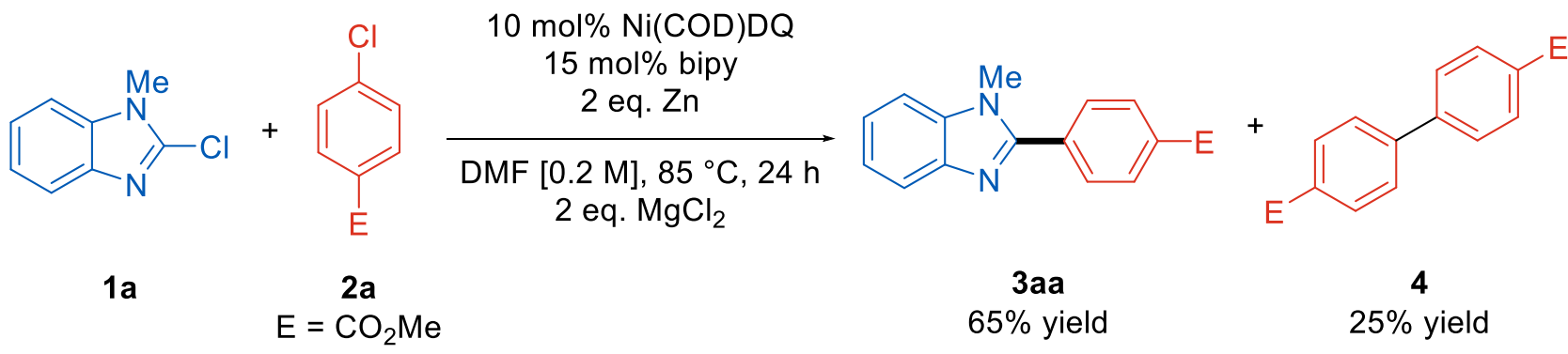




\subsubsection{Procedure for the Cross-Electrophile Coupling using Ni(COD)DQ in place of $\mathrm{Nil}_{2}$}

An oven-dried 2-dram vial was charged with a PTFE-coated stir bar and cooled under a positive pressure of argon. To the vial was added sequentially the $1 \mathrm{a}$ ( $33.3 \mathrm{mg}, 0.2 \mathrm{mmol}, 1 \mathrm{eq}$.), the $2 \mathrm{a}(51.2 \mathrm{mg}$, $0.3 \mathrm{mmol}, 1.5$ eq.), Ni(COD)DQ (6.6 mg, $10 \mathrm{~mol} \%), 2,2^{\prime}$-bipyridine $(4.7 \mathrm{mg}, 15 \mathrm{~mol} \%), \mathrm{Zn}(26.2 \mathrm{mg}, 0.4$ mmol, 2 eq.), and $\mathrm{MgCl}_{2}$ (38.1 $\mathrm{mg}, 0.4 \mathrm{mmol}, 2$ eq.). The vial was sealed with a screw cap fitted with a PTFE-faced silicone septum, and then DMF $(1 \mathrm{~mL}, 0.2 \mathrm{M}$ relative to the heteroaryl chloride) was added at room temperature under an atmosphere of argon. The argon balloon was removed and the vial was placed in an oil bath pre-heated to $85^{\circ} \mathrm{C}$ and stirred for $24 \mathrm{~h}$.

The reaction mixture was cooled to room temperature and filtered through a short plug of silica gel, eluting with ethyl acetate. The filtrate was then washed twice with water and twice with brine. The organic layer was then dried over $\mathrm{MgSO}_{4}$, and then filtered over a short plug of silica gel, eluting with ethyl acetate. A known amount of 1,3,5-trimethoxybenzene was added to the crude, and the sample was completely dissolved in $1 \mathrm{~mL}$ of $\mathrm{CDCl}_{3}$. The sample was analyzed by NMR using a 10 second relaxation delay. The yields were determined based on the integration of the compounds relative to 1,3,5-trimethoxybenzene.

\subsubsection{Procedure for the Cross-Electrophile Coupling using Ni(COD)DQ in place of $\mathrm{Nil}_{2}$ and adding $\mathrm{Mgl} 2$}

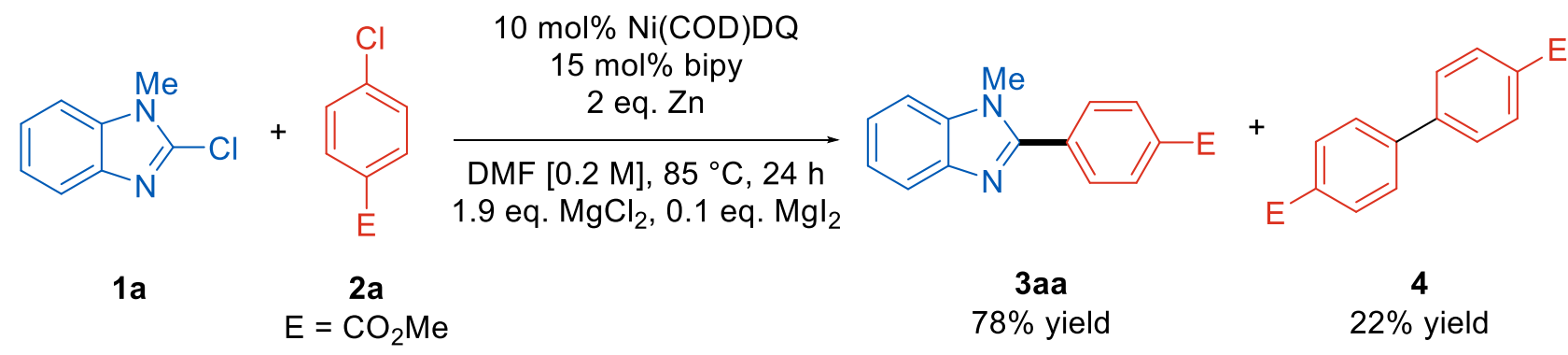

An oven-dried 2-dram vial was charged with a PTFE-coated stir bar and cooled under a positive pressure of argon. To the vial was added sequentially the $1 \mathrm{a}$ ( $33.3 \mathrm{mg}, 0.2 \mathrm{mmol}, 1 \mathrm{eq}$.), the $2 \mathrm{a}(51.2 \mathrm{mg}$, $0.3 \mathrm{mmol}, 1.5$ eq.), Ni(COD)DQ (6.6 mg, $10 \mathrm{~mol} \%), 2,2^{\prime}$-bipyridine $(4.7 \mathrm{mg}, 15 \mathrm{~mol} \%), \mathrm{Zn}(26.2 \mathrm{mg}, 0.4$ mmol, 2 eq.), $\mathrm{MgCl}_{2}$ (36.2 mg, $0.38 \mathrm{mmol}, 1.9$ eq.), and $\mathrm{Mgl}_{2}$ (5.6 mg, $0.02 \mathrm{mmol}, 0.1$ eq.). The vial was sealed with a screw cap fitted with a PTFE-faced silicone septum, and then DMF ( $1 \mathrm{~mL}, 0.2 \mathrm{M}$ relative to the heteroaryl chloride) was added at room temperature under an atmosphere of argon. The argon balloon was removed and the vial was placed in an oil bath pre-heated to $85^{\circ} \mathrm{C}$ and stirred for $24 \mathrm{~h}$.

The reaction mixture was cooled to room temperature and filtered through a short plug of silica gel, eluting with ethyl acetate. The filtrate was then washed twice with water and twice with brine. The organic layer was then dried over $\mathrm{MgSO}_{4}$, and then filtered over a short plug of silica gel, eluting with ethyl acetate. A known amount of 1,3,5-trimethoxybenzene was added to the crude, and the sample was completely dissolved in $1 \mathrm{~mL}$ of $\mathrm{CDCl}_{3}$. The sample was analyzed by NMR using a 10 second relaxation delay. The yields were determined based on the integration of the compounds relative to 1,3,5-trimethoxybenzene.

\subsubsection{Stoichiometric Experiment using Ni(COD)DQ and 1a, followed by Addition of 2a}

We suspected that the addition of $\mathrm{Zn}$ was leading to decomposition of the in situ generated (bipy) $\mathrm{Ni}^{\prime \prime} \mathrm{ArCl}$ complex. After having confirmed that $\mathrm{Ni}(\mathrm{COD}) \mathrm{DQ}$ was a competent pre-catalyst in the reaction, we aimed to use it in a stoichiometric experiment. 


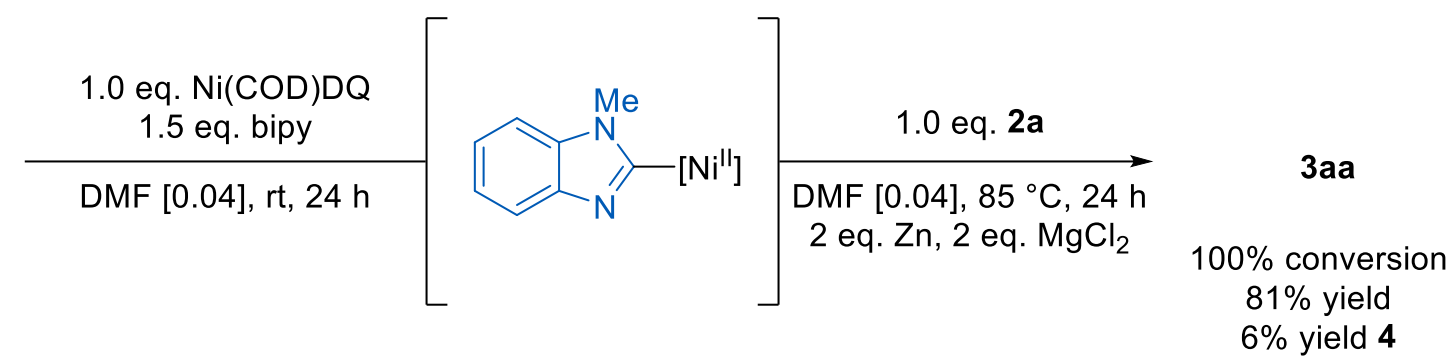

An oven-dried 2-dram vial was charged with a PTFE-coated stir bar and cooled under a positive pressure of argon. To the vial was added sequentially $1 \mathrm{a}$ ( $3.3 \mathrm{mg}, 0.02 \mathrm{mmol}, 1 \mathrm{eq}$.), Ni(COD)DQ (6.6 mg, $0.02 \mathrm{mmol}, 1$ eq.), and 2,2'-bipyridine ( $4.7 \mathrm{mg}, 0.03 \mathrm{mmol}, 1.5$ eq.). The vial was sealed with a screw cap fitted with a PTFE-faced silicone septum and then DMF $(0.5 \mathrm{~mL}, 0.04 \mathrm{M}$ relative to $1 \mathrm{a})$ was added at room temperature under an atmosphere of argon. The vial stirred at room temperature for 24 hours.

2a (3.4 mg, 0.02 mmol, 1 eq.), Zn (2.6 mg, 0.04 mmol, 2 eq.), and $\mathrm{MgCl}_{2}$ (3.8 mg, 0.04 mmol, 2 eq.) was added to a separate oven-dried 2-dram vial charged with a PTFE-coated stir bar cooled under a positive pressure of argon. DMF $(0.5 \mathrm{~mL}, 0.04 \mathrm{M}$ relative to $2 \mathrm{a}$ ) was added at room temperature under an atmosphere of argon. The $1 \mathrm{a} / \mathrm{Ni}$ solution was added to the solution of $\mathbf{2 a}$ via syringe. The vial was placed in an oil bath pre-heated to $85^{\circ} \mathrm{C}$ and stirred for $24 \mathrm{~h}$. The final concentration of the reaction is $0.02 \mathrm{M}$ relative to 1a. This concentration was chosen to mimic the concentration of the nickel catalyst in the standard reaction.

The reaction mixture was cooled to room temperature and the crude mixture was filtered through a short plug of silica gel, eluting with ethyl acetate. The filtrate was then washed twice with water and twice with brine. The organic layer was then dried over $\mathrm{MgSO}_{4}$ and then filtered over a short plug of silica gel, eluting with ethyl acetate. A known amount of 1,3,5-trimethoxybenzene was added to the crude, and the sample was completely dissolved in $1 \mathrm{~mL}$ of $\mathrm{CDCl}_{3}$. The sample was analyzed by NMR using a 10 second relaxation delay. The yields were determined based on the integration of the compounds relative to $1,3,5$ trimethoxybenzene.

\subsubsection{Stoichiometric Experiment using Ni(COD)DQ and 1a, followed by Addition of 1a}

$1 \mathbf{a}$

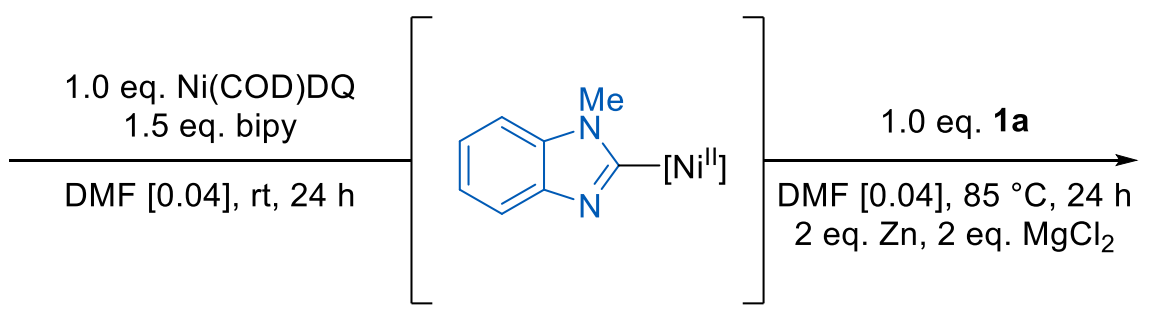

$39 \%$ recovered 1 a no homodimers formed

An oven-dried 2-dram vial was charged with a PTFE-coated stir bar and cooled under a positive pressure of argon. To the vial was added sequentially $1 \mathbf{a}(3.3 \mathrm{mg}, 0.02 \mathrm{mmol}, 1$ eq.), Ni(COD)DQ (6.6 mg, $0.02 \mathrm{mmol}, 1$ eq.), and 2,2'-bipyridine $(4.7 \mathrm{mg}, 0.03 \mathrm{mmol}, 1.5 \mathrm{eq})$. The vial was sealed with a screw cap fitted with a PTFE-faced silicone septum and then DMF $(0.5 \mathrm{~mL}, 0.04 \mathrm{M}$ relative to 1a) was added at room temperature under an atmosphere of argon. The vial stirred at room temperature for 24 hours.

1a (3.3 mg, $0.02 \mathrm{mmol}, 1$ eq.), $\mathrm{Zn}$ ( $2.6 \mathrm{mg}, 0.04 \mathrm{mmol}, 2$ eq.), and $\mathrm{MgCl}_{2}$ (3.8 mg, 0.04 mmol, 2 eq.) was added to a separate oven-dried 2-dram vial charged with a PTFE-coated stir bar cooled under a 
positive pressure of argon. DMF $(0.5 \mathrm{~mL}, 0.04 \mathrm{M}$ relative to $1 \mathrm{a})$ was added at room temperature under an atmosphere of argon. The $1 \mathrm{a} / \mathrm{Ni}$ solution was added to the solution of $1 \mathrm{a}$ via syringe. The vial was placed in an oil bath pre-heated to $85^{\circ} \mathrm{C}$ and stirred for $24 \mathrm{~h}$. The final concentration of the reaction is $0.02 \mathrm{M}$ relative to 1a. This concentration was chosen to mimic the concentration of the nickel catalyst in the standard reaction.

The reaction mixture was cooled to room temperature and the crude mixture was filtered through a short plug of silica gel, eluting with ethyl acetate. The filtrate was then washed twice with water and twice with brine. The organic layer was then dried over $\mathrm{MgSO}_{4}$ and then filtered over a short plug of silica gel, eluting with ethyl acetate. A known amount of 1,3,5-trimethoxybenzene was added to the crude, and the sample was completely dissolved in $1 \mathrm{~mL}$ of $\mathrm{CDCl}_{3}$. The sample was analyzed by NMR using a 10 second relaxation delay. The yields were determined based on the integration of the compounds relative to 1,3,5trimethoxybenzene.

\subsubsection{Stoichiometric Experiment using Ni(COD)DQ and 2a, followed by Addition of 1a}

$2 a$
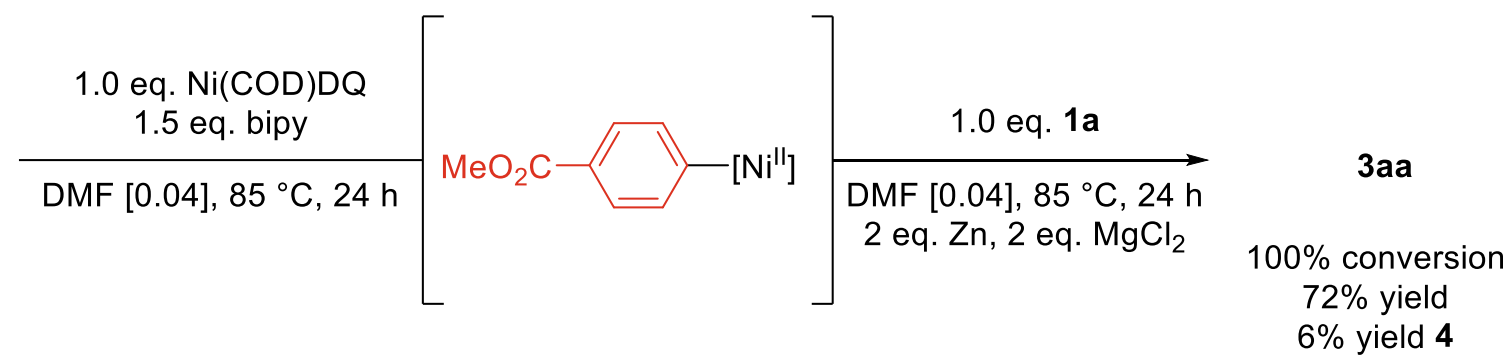

An oven-dried 2-dram vial was charged with a PTFE-coated stir bar and cooled under a positive pressure of argon. To the vial was added sequentially $2 \mathrm{a}(3.4 \mathrm{mg}, 0.02 \mathrm{mmol}, 1$ eq.), Ni(COD)DQ (6.6 mg, $0.02 \mathrm{mmol}, 1$ eq.), and 2,2'-bipyridine ( $4.7 \mathrm{mg}, 0.03 \mathrm{mmol}, 1.5$ eq.). The vial was sealed with a screw cap fitted with a PTFE-faced silicone septum and then DMF $(0.5 \mathrm{~mL}, 0.04 \mathrm{M}$ relative to $2 \mathrm{a})$ was added at room temperature under an atmosphere of argon. The vial stirred at room temperature for 24 hours.

1a (3.3 mg, $0.02 \mathrm{mmol}, 1$ eq.), Zn (2.6 mg, $0.04 \mathrm{mmol}, 2$ eq.), and $\mathrm{MgCl}_{2}$ (3.8 mg, $0.04 \mathrm{mmol}, 2$ eq.) was added to a separate oven-dried 2-dram vial charged with a PTFE-coated stir bar cooled under a positive pressure of argon. DMF $(0.5 \mathrm{~mL}, 0.04 \mathrm{M}$ relative to $1 \mathrm{a})$ was added at room temperature under an atmosphere of argon. The $\mathbf{2 a} / \mathrm{Ni}$ solution was added to the solution of $1 \mathrm{a}$ via syringe. The vial was placed in an oil bath pre-heated to $85^{\circ} \mathrm{C}$ and stirred for $24 \mathrm{~h}$. The final concentration of the reaction is $0.02 \mathrm{M}$ relative to $\mathbf{2 a}$. This concentration was chosen to mimic the concentration of the nickel catalyst in the standard reaction.

The reaction mixture was cooled to room temperature and the crude mixture was filtered through a short plug of silica gel, eluting with ethyl acetate. The filtrate was then washed twice with water and twice with brine. The organic layer was then dried over $\mathrm{MgSO}_{4}$ and then filtered over a short plug of silica gel, eluting with ethyl acetate. A known amount of 1,3,5-trimethoxybenzene was added to the crude, and the sample was completely dissolved in $1 \mathrm{~mL}$ of $\mathrm{CDCl}_{3}$. The sample was analyzed by NMR using a 10 second relaxation delay. The yields were determined based on the integration of the compounds relative to 1,3,5trimethoxybenzene. 


\subsubsection{Stoichiometric Experiment using Ni(COD)DQ and 2a, followed by Addition of 2a}

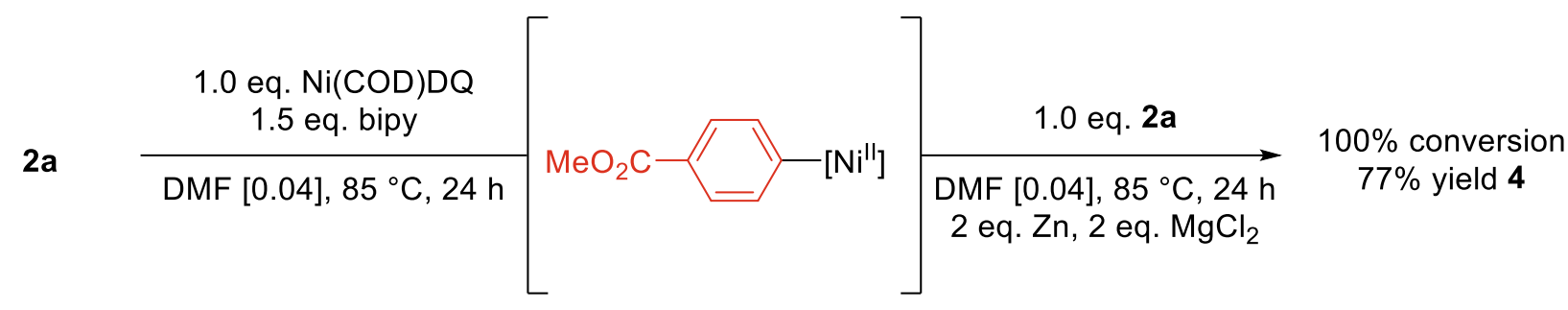

An oven-dried 2-dram vial was charged with a PTFE-coated stir bar and cooled under a positive pressure of argon. To the vial was added sequentially $2 \mathrm{a}$ ( $3.4 \mathrm{mg}, 0.02 \mathrm{mmol}, 1$ eq.), Ni(COD)DQ (6.6 mg, $0.02 \mathrm{mmol}$, 1 eq.), and 2,2'-bipyridine ( $4.7 \mathrm{mg}, 0.03 \mathrm{mmol}, 1.5 \mathrm{eq}$.). The vial was sealed with a screw cap fitted with a PTFE-faced silicone septum and then DMF $(0.5 \mathrm{~mL}, 0.04 \mathrm{M}$ relative to $2 \mathrm{a}$ ) was added at room temperature under an atmosphere of argon. The vial stirred at room temperature for 24 hours.

2a (3.4 mg, $0.02 \mathrm{mmol}, 1$ eq.), $\mathrm{Zn}$ (2.6 mg, $0.04 \mathrm{mmol}, 2$ eq.), and $\mathrm{MgCl}_{2}$ (3.8 mg, $0.04 \mathrm{mmol}, 2$ eq.) was added to a separate oven-dried 2-dram vial charged with a PTFE-coated stir bar cooled under a positive pressure of argon. DMF $(0.5 \mathrm{~mL}, 0.04 \mathrm{M}$ relative to $2 \mathrm{a})$ was added at room temperature under an atmosphere of argon. The $\mathbf{2 a} / \mathrm{Ni}$ solution was added to the solution of $\mathbf{2 a}$ via syringe. The vial was placed in an oil bath pre-heated to $85^{\circ} \mathrm{C}$ and stirred for $24 \mathrm{~h}$. The final concentration of the reaction is $0.02 \mathrm{M}$ relative to $2 \mathrm{a}$. This concentration was chosen to mimic the concentration of the nickel catalyst in the standard reaction.

The reaction mixture was cooled to room temperature and the crude mixture was filtered through a short plug of silica gel, eluting with ethyl acetate. The filtrate was then washed twice with water and twice with brine. The organic layer was then dried over $\mathrm{MgSO}_{4}$ and then filtered over a short plug of silica gel, eluting with ethyl acetate. A known amount of 1,3,5-trimethoxybenzene was added to the crude, and the sample was completely dissolved in $1 \mathrm{~mL}$ of $\mathrm{CDCl}_{3}$. The sample was analyzed by NMR using a 10 second relaxation delay. The yields were determined based on the integration of the compounds relative to 1,3,5trimethoxybenzene.

\subsubsection{Stoichiometric Experiment using Ni(COD)DQ and 2a, followed by Addition of 1a and 2a}

2a

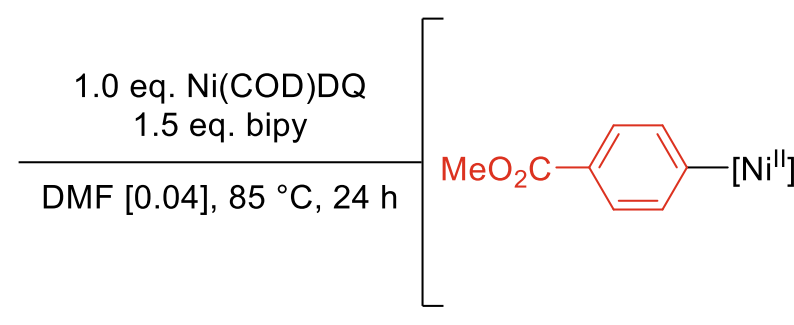

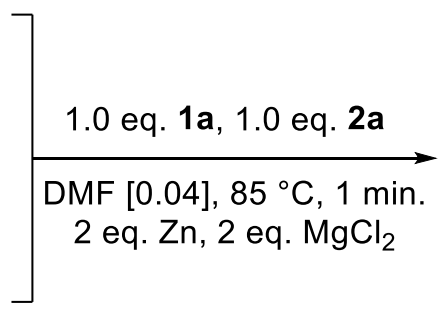

DMF [0.04], $85^{\circ} \mathrm{C}, 1 \mathrm{~min}$
$10 \%$ yield 4 $91 \%$ recovered 1 a $76 \%$ recovered $2 a$ $0 \%$ yield 3 aa

An oven-dried 2-dram vial was charged with a PTFE-coated stir bar and cooled under a positive pressure of argon. To the vial was added sequentially $2 \mathrm{a}$ ( $3.4 \mathrm{mg}, 0.02 \mathrm{mmol}, 1$ eq.), Ni(COD)DQ (6.6 mg, $0.02 \mathrm{mmol}$, 1 eq.), and 2,2'-bipyridine ( $4.7 \mathrm{mg}, 0.03 \mathrm{mmol}, 1.5$ eq.). The vial was sealed with a screw cap fitted with a PTFE-faced silicone septum and then DMF $(0.5 \mathrm{~mL}, 0.04 \mathrm{M}$ relative to $2 \mathrm{a})$ was added at room temperature under an atmosphere of argon. The vial stirred at room temperature for 24 hours.

1a (3.3 mg, $0.02 \mathrm{mmol}, 1$ eq.), 2 a (3.4 mg, $0.02 \mathrm{mmol}, 1$ eq.), $\mathrm{Zn}$ ( $2.6 \mathrm{mg}, 0.04 \mathrm{mmol}, 2$ eq.), and $\mathrm{MgCl}_{2}$ (3.8 $\mathrm{mg}, 0.04 \mathrm{mmol}, 2$ eq.) was added to a separate oven-dried 2-dram vial charged with a PTFE-coated 
stir bar cooled under a positive pressure of argon. DMF $(0.5 \mathrm{~mL}, 0.04 \mathrm{M}$ relative to $1 \mathrm{a})$ was added at room temperature under an atmosphere of argon. The $2 \mathrm{a} / \mathrm{Ni}$ solution was added to the solution of $\mathbf{2 a}$ via syringe. The vial was placed in an oil bath pre-heated to $85^{\circ} \mathrm{C}$ and stirred. After 1 minute, the reaction was quenched by addition of $1 \mathrm{~mL}$ of saturated $\mathrm{NH}_{4} \mathrm{Cl}_{\text {(aq) }}$.

The reaction mixture was cooled to room temperature and the crude mixture was filtered through a short plug of silica gel, eluting with ethyl acetate. The filtrate was then washed twice with water and twice with brine. The organic layer was then dried over $\mathrm{MgSO}_{4}$ and then filtered over a short plug of silica gel, eluting with ethyl acetate. A known amount of 1,3,5-trimethoxybenzene was added to the crude, and the sample was completely dissolved in $1 \mathrm{~mL}$ of $\mathrm{CDCl}_{3}$. The sample was analyzed by NMR using a 10 second relaxation delay. The yields were determined based on the integration of the compounds relative to 1,3,5trimethoxybenzene.

The sole product formed at low conversions was 4 . This suggests that the Ni"ArX intermediate preferentially reacts with another aryl chloride to form the homocoupled product instead of the heteroaryl chloride. This is not observed experimentally, where the cross-product is favoured. Since the homocoupling is observed in only small quantities in the catalytic reaction, the Ni"ArX species must not be a competent intermediate in the reaction. This suggests that the first oxidative addition occurs via insertion into the heteroaryl-Cl bond. The resultant (heteroaryl) Ni"Cl species is unable to react with another equivalent of the heteroaryl chloride, avoiding the formation of possible homodimers. Instead, the $\mathrm{Ni}^{\mathrm{il}}$ intermediate reacts with the aryl chloride to form the desired cross product.

\subsubsection{Summary of the Stoichiometric Experiments using Ni(COD)DQ}
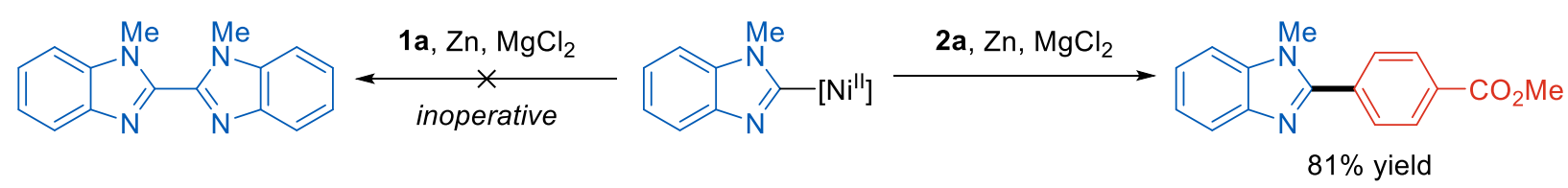

2a, $\mathrm{Zn}, \mathrm{MgCl}_{2}$

$$
\text { preferred }
$$

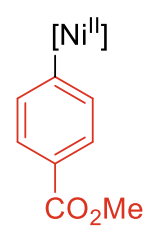<smiles>COC(=O)c1ccc(-c2nc3ccccc3n2C)cc1</smiles>

$77 \%$ yield 
$5.10^{1} \mathrm{H}$ NMR Spectrum of the Crude Reaction between a Heteroaryl Chloride and an Electron-Rich Aryl Chloride

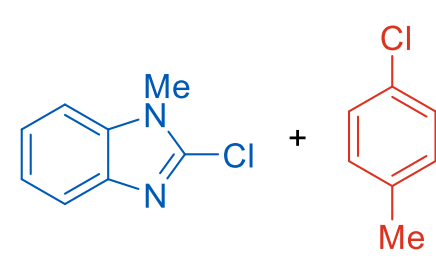

$1 \mathrm{a}$

$2 \mathrm{~h}$

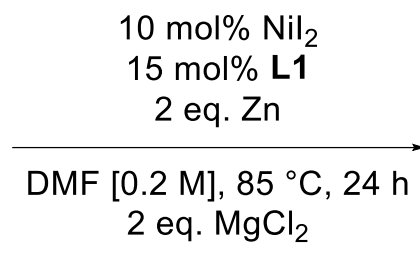

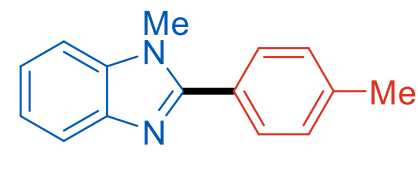

3ta

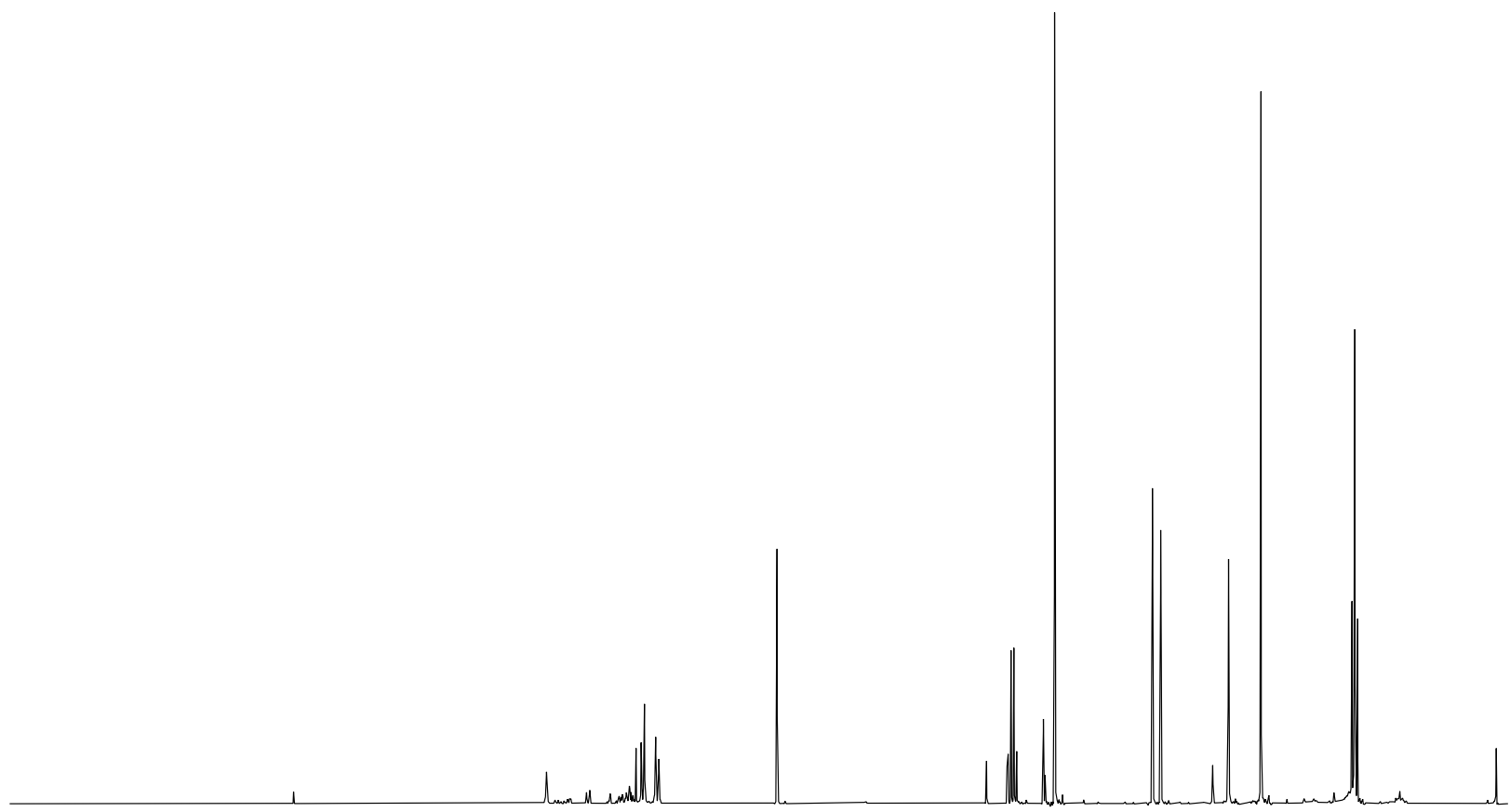

$\begin{array}{lllllllllllllllllllllllllllllllll}2.5 & 12.0 & 11.5 & 11.0 & 10.5 & 10.0 & 9.5 & 9.0 & 8.5 & 8.0 & 7.5 & 7.0 & \begin{array}{c}1 \\ \mathrm{f} 1(\mathrm{ppm})\end{array} & 6.0 & 5.5 & 5.0 & 4.5 & 4.0 & 3.5 & 3.0 & 2.5 & 2.0 & 1.5 & 1.0 & 0.5 & 0 .\end{array}$ 


\section{References}

1) Still, W.C.; Kahn, M.; Mitra, A. Rapid Chromatographic Technique for Preparative Separations with Moderate Resolution. J. Org. Chem. 1978, 43, 2923-2925

2) Lee, Y. H.; Morandi, B. Metathesis-Active Ligands Enable a Catalytic Functional Group Metathesis between Aroyl Chlorides and Aryl lodides. Nat. Chem. 2018, 10, 1016-1022

3) Fletcher, S.; Drennen, B. Carboxylic Acid, Acyl Sulfonamide and Acyl Sulfamide-Derivatized Bicyclic Aza-Heteroaromatics as Selective MCL-1 Inhibitors and as Dual MCL-1/BCL-2 Inhibitors. US2020299285A1, 2020

4) Hayashi, E.; Yamaguchi, Y.; Kita, Y.; Kamata, K.; Hara, M. One-pot Aeriobic Oxidative Sulfonamidation of Aromatic Thiols with Ammonia by a Dual-Functional $\beta-\mathrm{MnO}_{2}$ Nanocatalyst. Chem. Commun. 2020, 56, 2095-2098

5) Pagliero, R. J.; Pierini, A. B.; Brun, R.; Mazzieri, M.R. Design, Synthesis and 3-D Characterization of 1Benzenesulfonyl-1,2,3,4-Tetrahydroquinolines as Lead Scaffold for Antiparasitic Drug. Letters in Drug Design \& Discovery 2010, 7, 461-470

6) Kösterke, T.; Pape, T.; Hahn, F.E. Synthesis of NHC Complexes by Oxidative Addition of 2-Chloro-Nmethylbenzimidazole. J. Am. Chem. Soc. 2011, 133, 2112-2115

7) D’Attoma, J.; Camara, T.; Brun, P.L.; Robin, Y.; Bostyn, S.; Buron, F.; Routier, S. Efficient Transposition of the Sandmeyer Reaction from Batch to Continuous Process. Org. Process Res. Dev. 2017, 21, 4451

8) Jallapally, A.; Addla, D.; Bagul, P.; Sridhar, B.; Banerjee, S. K. Design, Synthesis, and Evaluation of Novel 2-Butyl-4-Chloroimidazole Derived Peptidomimetics as Angiotensin Converting Enzyme (ACE) Inhibitors. Bioorg. Med. Chem. 2015, 23, 3526-3533

9) Kantevari, S.; Addla, D.; Bagul, P. K.; Sridhar, B.; Banerjee, S. K. Synthesis and Evaluation of Novel 2Butyl-4-Chloro-1-Methylimidazole Embedded Chalcones and Pyrazoles as Angiotensin Converting Enzyme (ACE) Inhibitors. Bioorg. Med. Chem. 2011, 19, 4772-4781

10) Chen, S.; Graceffa, R. F.; Boezio, A. A. Direct, Regioselective N-Alkylation of 1,3-Azoles. Org. Lett. 2016, 18, 16-19

11) Axten, J. M; Medina, J. R.; Feng, Y.; Shu, A.; Romeril, S. P.; Grant, S. W.; Li, W. H. H.; Heerding, D. A.; Minthorn, E.; Mencken, T.; Atkins, C.; Liu, Q.; Rabindran, S.; Kumar, R.; Hong, X.; Goetz, A.; Stanley, T.; Taylor, J. D.; Sigethy, S. D.; Tomberlin, G. H.; Hassell, A. M.; Kahler, K. M.; Shewchuk, L. M.; Gampe, R. T. Discovery of 7-Methyl-5-(1-\{[3-(trifluoromethyl)phenyl]acetyl\}-2,3-dihydro-1H-indol-5-yl)-7Hpyrrolo[2,3-d]pyrimidin-4-amine (GSK2606414), a Potent and Selective First-in-Class Inhibitor of Protein Kinase R (PKR)-like Endoplasmic Reticulum Kinase (PERK). J. Med. Chem. 2012, 55, 7193-7207

12) Sharma, S. H.; Pablo, J. L.; Montesinos, M. S.; Greka, A.; Hopkins, C. R. Design, Synthesis and Characterization of Novel $\mathrm{N}$-Heterocyclic-1-benzyl-1H-benzo[d]imidazole-2-amines as Selective TRPC5 Inhibitors Leading to the Identification of the Selective Compound, AC1903. Bioorg. Med. Chem. Lett. 2019, 29, 155-159

13) Choi, M.A.; Park, S.Y.; Chae, H.Y.; Song, Y.; Sharma, C.; Seo, Y.H. Design, Synthesis and Biological Evaluation of a Series of CNS Penetrant HDAC Inhibitors Structurally Derived from Amyloid- $\beta$ Probes. Scientific Reports 2019, 9, 1-12

14) Thapa, P.; Palacios, P.M.; Tran, T.; Pierce, B.S.; Foss Jr., F.W. 1,2-Disubstituted Benzimidazoles by the Iron Catalyzed Cross-Dehydrogenative Coupling of Isomeric 0 -Phenylenediamine Substrates. J. Org. Chem. 2020, 85, 1991-2009 
15) Li, G.; He, R.; Liu, Q.; Wang, Z.; Liu, Y.; Wang, Q. Formation of Amidinyl Radicals via Visible-LightPromoted Reduction of $\mathrm{N}$-Phenyl Amidoxime Esters and Application to the Synthesis of 2-Substituted Benzimidazoles. J. Org. Chem. 2019, 84, 8646-8660

16) Ackermann, L.; Althammer, A.; Fenner, S. Palladium-Catalyzed Direct Arylations of Heteroarenes with Tosylates and Mesylates. Angew. Chem. Int. Ed. 2008, 48, 201-204.

17) Gong, L-Z.; Knochel, P. Preparation of Highly Functionalized Heterocyclic Zinc Organometallics via a Li(acac)-Catalysis of the I/Zn-Exchange Reaction. Synlett 2005, 2, 267-270

18) Gosmini, C.; Bassene-Ernst, C.; Durandetti, M. Synthesis of Functionalized 2-Arylpyridines from 2Halopyridines and Various Aryl Halides via a Nickel Catalysis. Tetrahedron 2009, 65, 6141-6146

19) Xie, C.; Han, X.; Gong, J.; Li, D.; Ma, C. One-pot strategy of copper-catalyzed synthesis of 1,2disubstituted benzimidazoles. Org. Biomol. Chem. 2017, 15, 5811-5819

20) Uslu, A. G.; Maz, T. G.; Nocentini, A.; Banoglu, E.; Supuran, C. T.; Çalişkan, B. Benzimidazole Derivatives as Potent and Isoform Selective Tumor-Associated Carbonic Anhydrase IX/XII Inhibitors. Bioorganic Chem. 2020, 95, 103544-103551

21) Huang, J.; Chan, J.; Chen, Y.; Borths, C. J.; Baucom, K. D.; Larsen, R. D.; Faul, M. M. A Highly Efficient Palladium/Copper Cocatalytic System for Direct Arylation of Heteroarenes: An Unexpected Effect of Cu(Xantphos)I J. Am. Chem. Soc. 2010, 132, 3674-3675

22) Liu, B.; Qin, X.; Li, K.; Guo, Q.; Lan, J.; You, J. A Palladium/Copper Bimetallic Catalytic System: Dramatic Improvement for Suzuki-Miyaura-Type Direct C-H Arylation of Azoles with Arylboronic Acids. Chem. Eur. J. 2010, 16, 11836-11839.

23) Zhao, L-L.; Liu, W.; Zhang, Z.; Zhao, H.; Wang, Q.; Yan, X. Ruthenium-Catalyzed ortho- and meta-H/D Exchange of Arenes. Org. Lett. 2019, 21, 10023-10027

24) Chakrabarty, M.; Mukherji, A.; Mukherjee R.; Arima, S.; Harigaya, Y. A Keggin Heteropoly Acid as an Efficient Catalyst for an Expeditious, One-Pot Synthesis of 1-Methyl-2-(hetero)arylbenzimidazoles. Tetrahedron Lett. 2007, 48, 5239-5242

25) Hachiya, H.; Hirano, K.; Satoh, T.; Miura, M. Nickel-Catalyzed Direct C-H Arylation and Alkenylation of Heteroarenes with Organosilicon Reagents. Angew. Chem. Int. Ed. 2010, 49, 2202-2205.

26) Sluiter, J.; Christoffers, J. Synthesis of 1-Methylbenzimidazoles from Carbonitriles. Syn. Lett. 2009, 1, 63-66

27) Nguyen, K. M. H.; Largeron, M. Catalytic Oxidative Coupling of Primary Amines under Air: A Flexible Route to Benzimidazole Derivatives. Eur. J. Org. Chem. 2016, 2016, 1025-1032

28) Wang, T. -H.; Ambre, R.; Wang, Q.; Lee, W. -C.; Wang, P. -C.; Liu, Y.; Zhao, L.; Ong, T. -G. NickelCatalyzed Heteroarenes Cross Coupling via Tandem C-H/C-O Activation. ACS Catal. 2018, 8, 1136811376.

29) Barbero, N.; SanMartin, R.; Domínguez, E. Ligand-free Copper(I)-Catalysed Intramolecular Direct C-H Functionalization of Azoles. Org. Biomol. Chem. 2010, 8, 841-845.

30) Kang, K.; Huang, L.; Weix, D.J. Sulfonate Versus Sulfonate: Nickel and Palladium Multimetallic CrossElectrophile Coupling of Aryl Triflates with Aryl Tosylates. J. Am. Chem. Soc. 2020, 142, 10634-10640.

31) Yokoyama, A.; Maruyama, T.; Tagami, K.; Masu, H.; Katagiri, K.; Azumaya, I.; Yokozawa, T. One-Pot Synthesis of Cyclic Triamides with a Triangular Cavity from trans-Stilbene and Diphenylacetylene Monomers. Org. Lett. 2008, 10, 3207-3210.

32) Huang, L.; Ackerman, L. K. G.; Kang, K.; Parsons, A. M.; Weix, D. J. LiCl-Accelerated Multimetallic CrossCoupling of Aryl Chlorides with Aryl Triflates. J. Am. Chem. Soc. 2019, 141, 10978-10983. 
33) Wang, X.; Ma, G.; Peng, Y.; Pitsch, C. E.; Moll, B. J.; Ly, T. D.; Wang, X.; Gong, H. Ni-Catalyzed Reductive Coupling of Electron-Rich Aryl lodides with Tertiary Alkyl Halides. J. Am. Chem. Soc. 2018, 140, 1449014497.

34) Lin, Q.; Diao, T. Mechanism of the Ni-Catalyzed Reductive 1,2-Dicarbofunctionalization of Alkenes. J. Am. Chem. Soc. 2019, 141, 17937-17948.

35) Wu, F.; Lu, W.; Qian, Q.; Ren, Q.; Gong, H. Ketone Formation via Mild Nickel-Catalyzed Reductive Coupling of Alkyl Halides with Aryl Acid Chlorides. Org. Lett. 2012, 14, 3044-3047.

36) Sayyed, F. B.; Sakaki, S. The Crucial Roles of $\mathrm{MgCl}_{2}$ as a Non-Innocent Additive in the Ni-Catalyzed Carboxylation of Benzyl Halide with $\mathrm{CO}_{2}$. Chem. Commun. 2014, 50, 13026-13029.

37) Everson, D. A.; Shrestha, R.; Weix, D. J. Nickel-Catalyzed Reductive Cross-Coupling of Aryl Halides with Alkyl Halides. J. Am. Chem. Soc. 2010, 132, 920-921.

38) DeLano, T. J.; Dibrell, S. E.; Lacker, C. R.; Pancoast, A. R.; Poremba, K. E.; Cleary, L.; Sigman, M. S.; Reisman, S. E. Nickel-catalyzed Asymmetric Reductive Cross-Coupling of $\alpha$-Chloroesters with (Hetero)aryl lodides. Chem. Sci. 2021, 12, 7758-7762. 
7. NMR Spectra of Heteroaryl Chlorides 


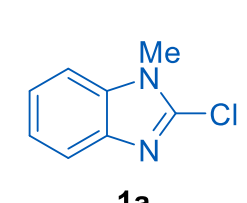

1a
นึำนกำ ํㅜำ

रा।

mi

(2)

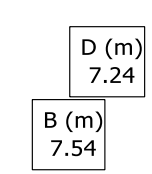

A (dd)

$J(7.9,1.2)$
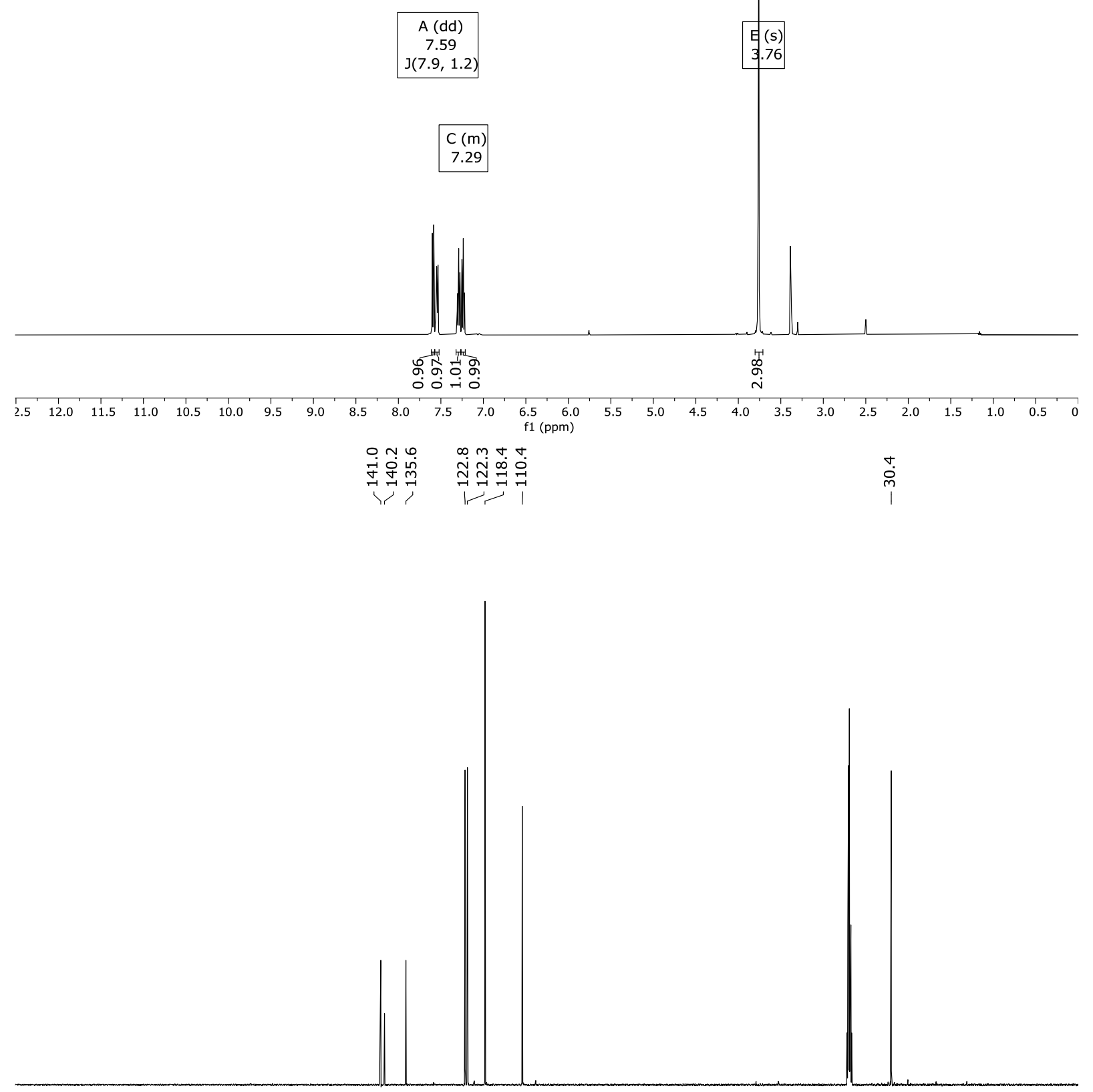

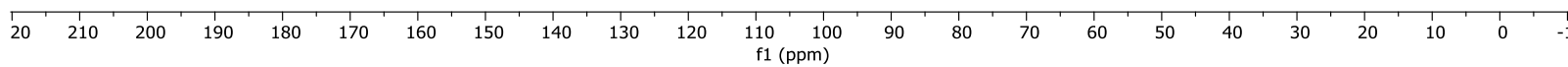



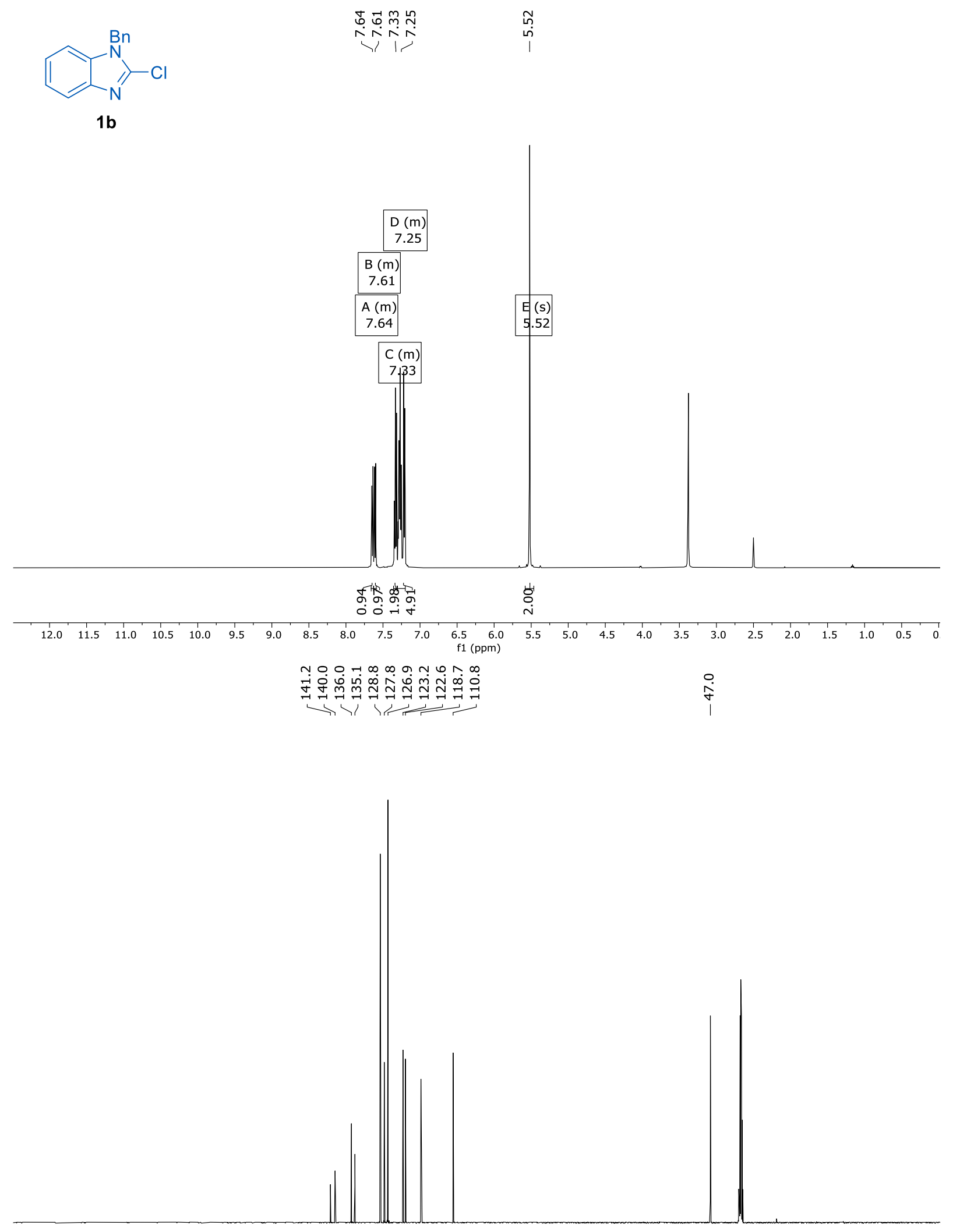

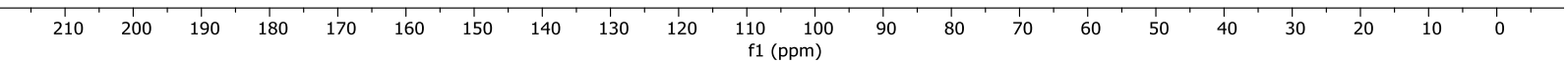



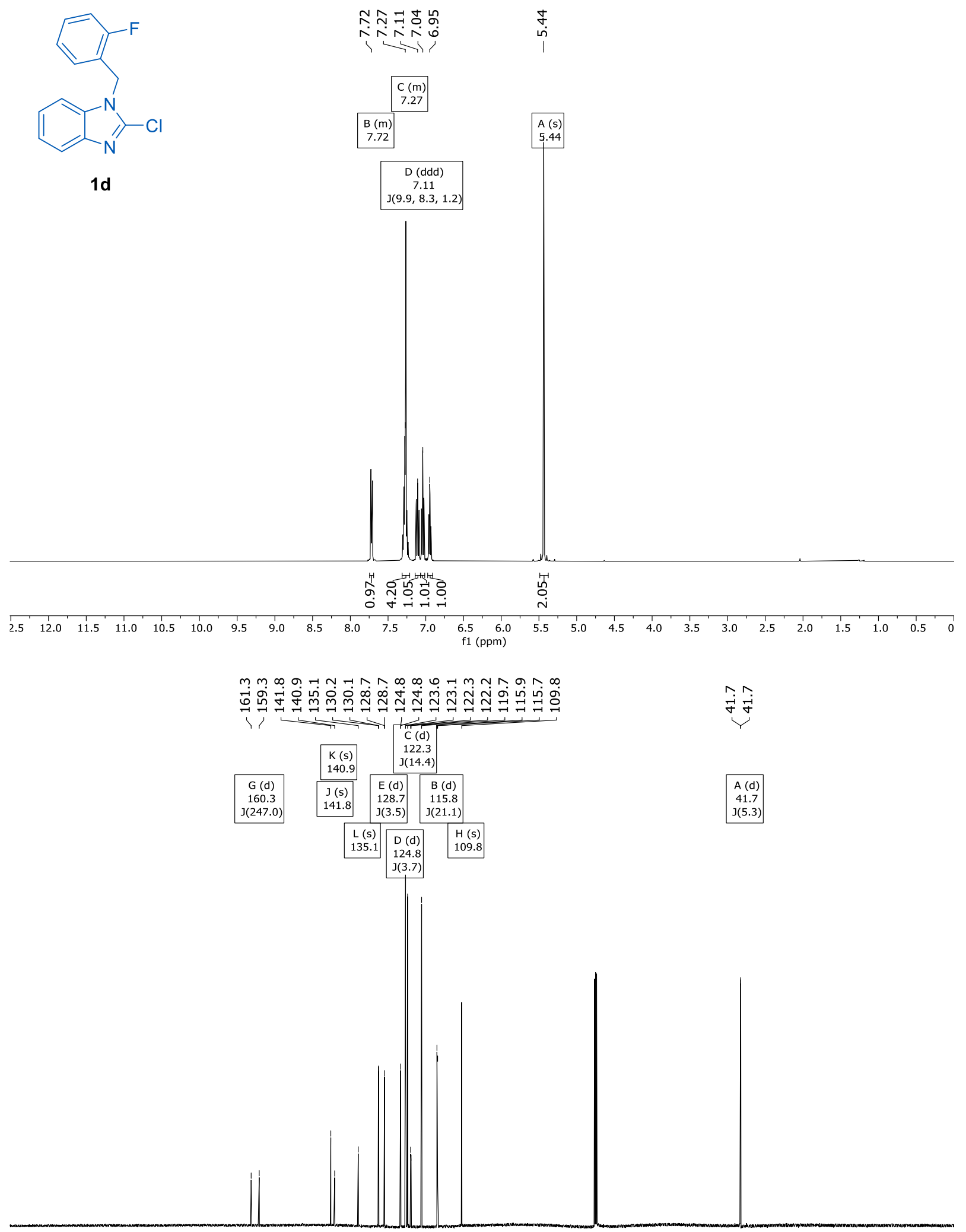

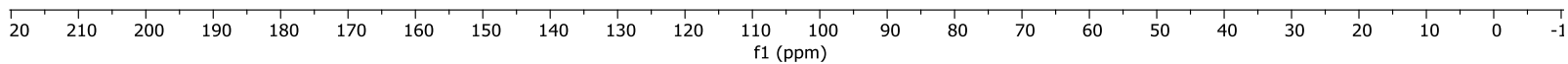




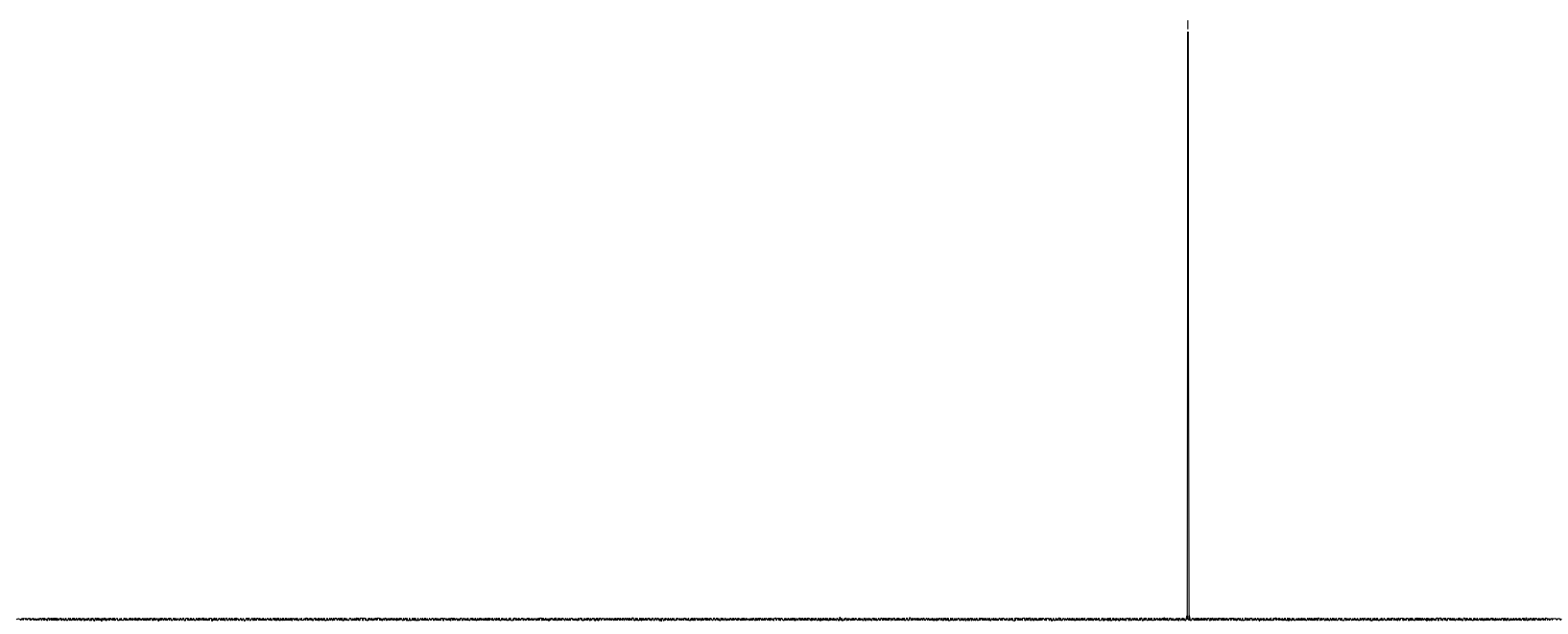

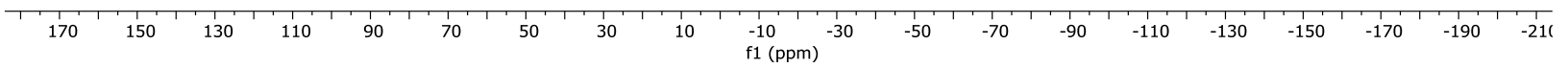



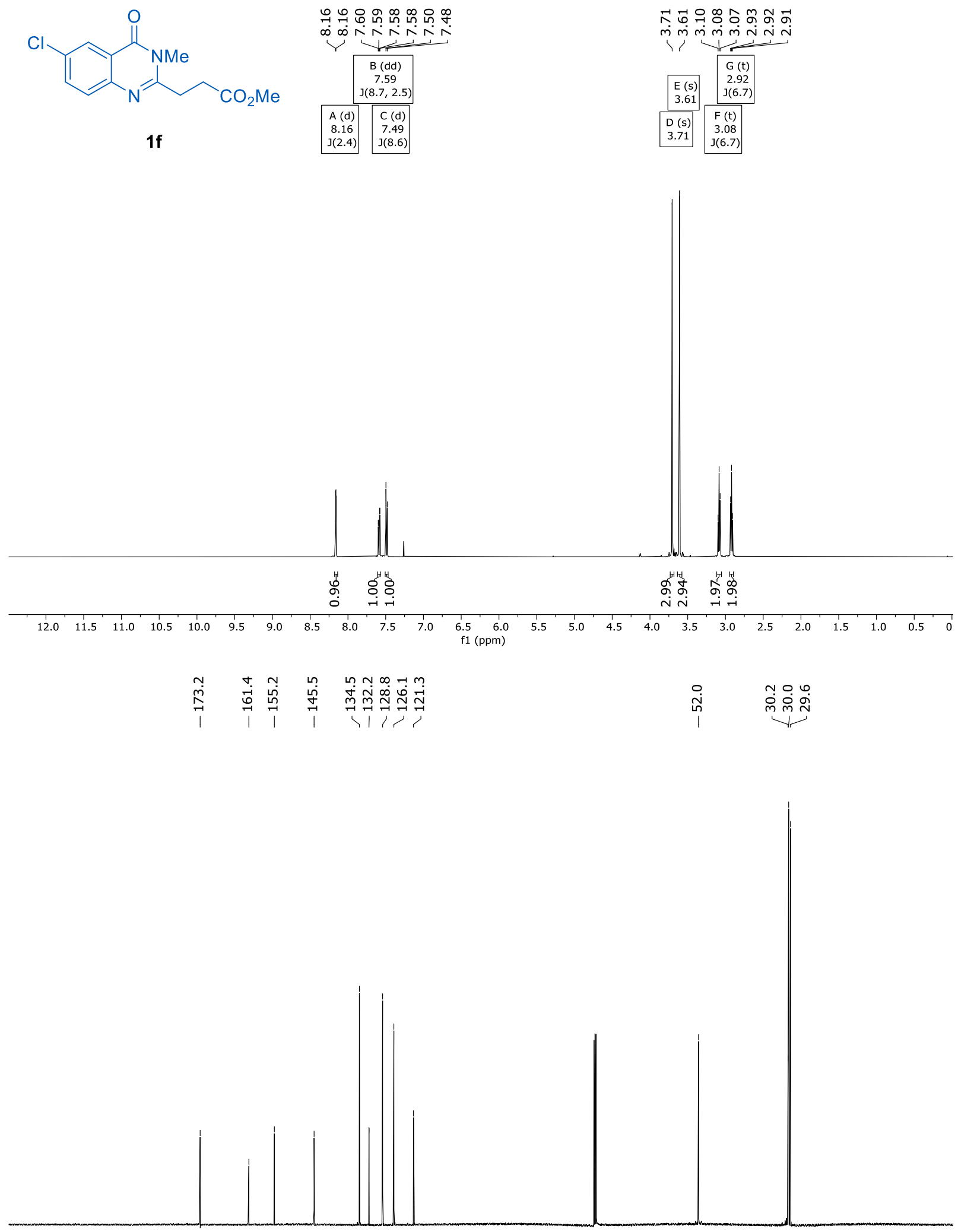

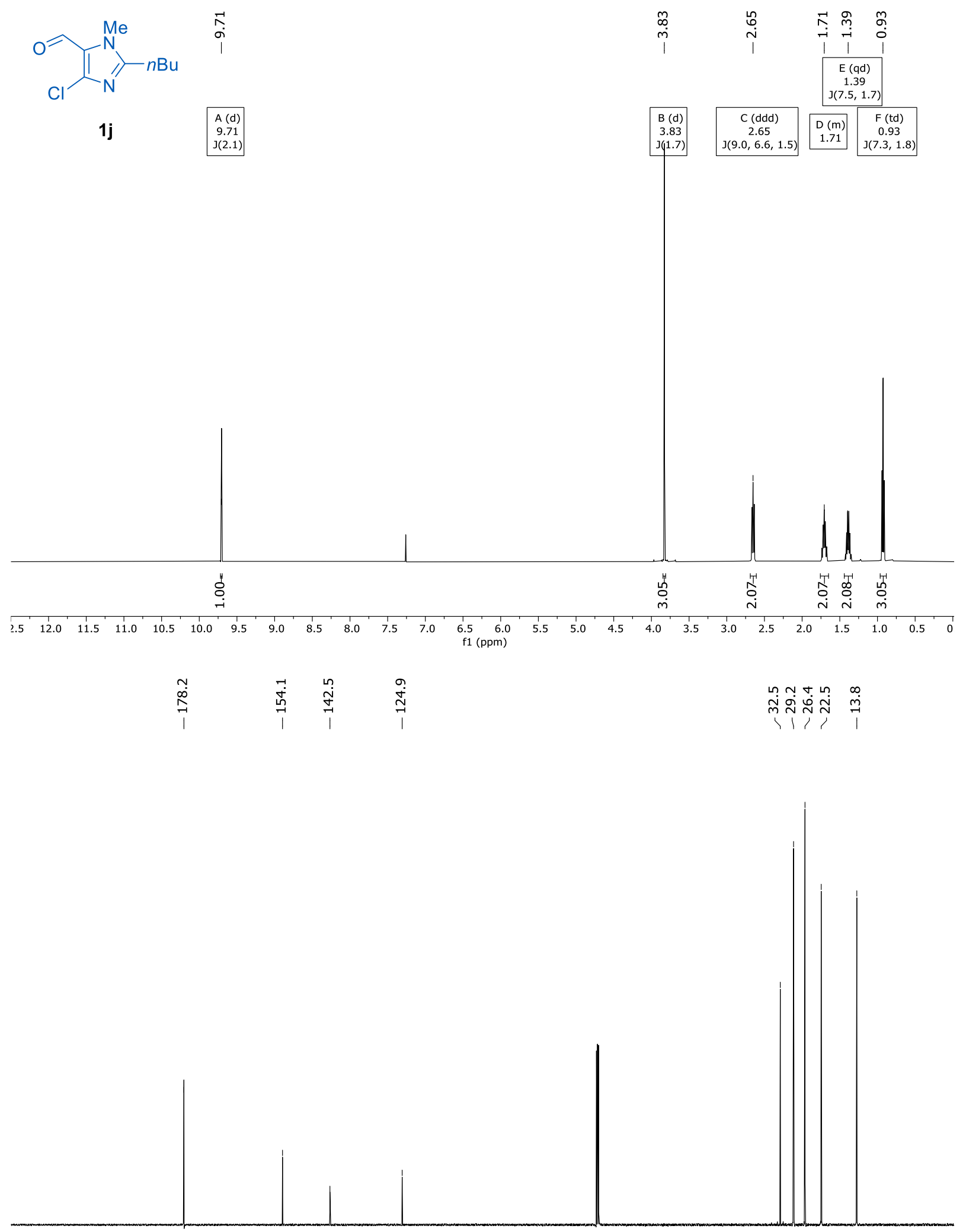

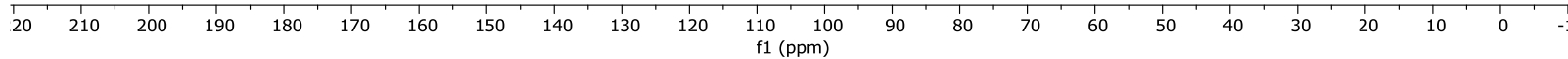




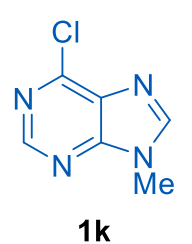

$\stackrel{m}{*}$

$\infty$
1
1

$\stackrel{\substack{\infty \\ m}}{\dot{\infty}}$

C (s)

8.62

B (s)
8.73

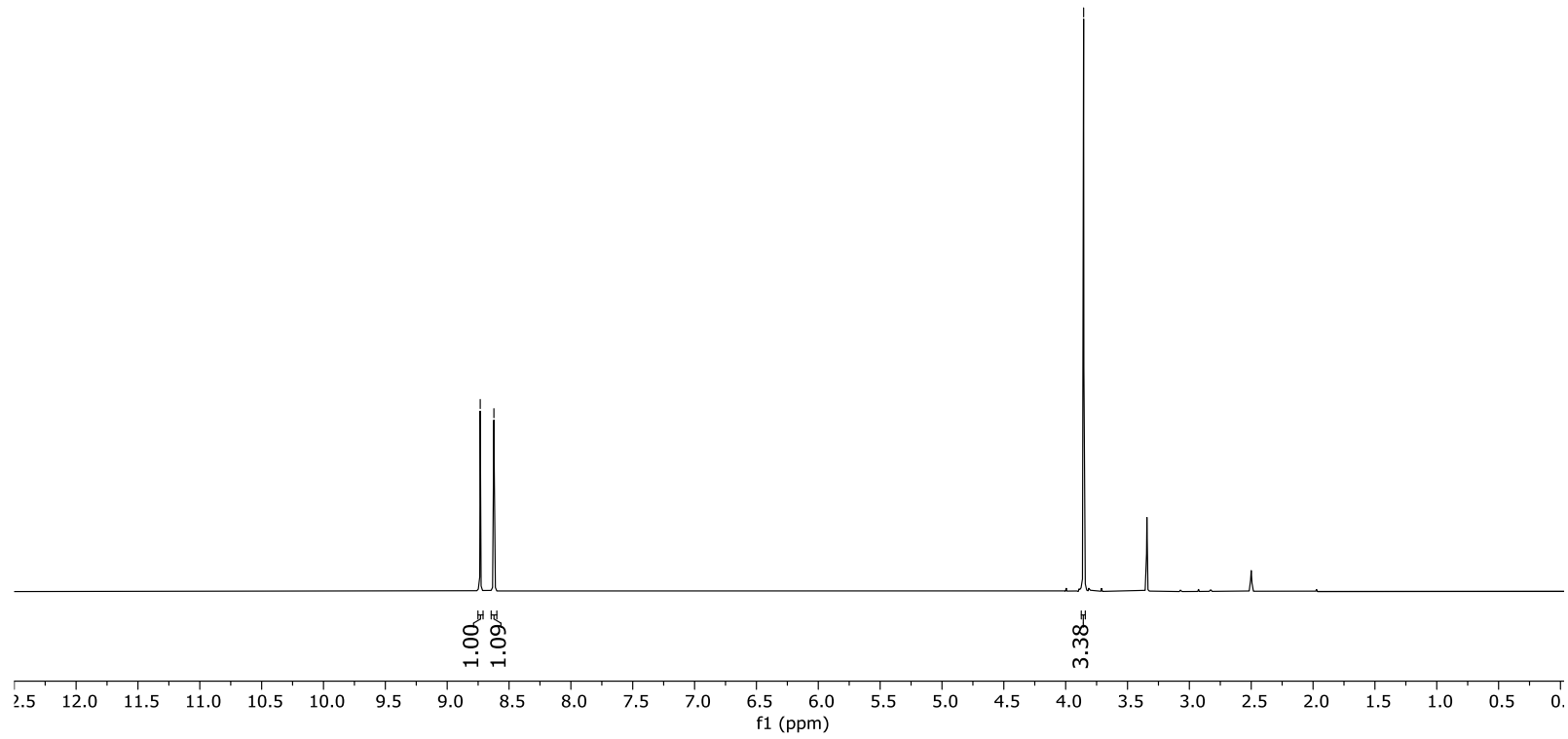

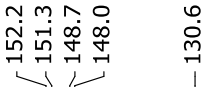

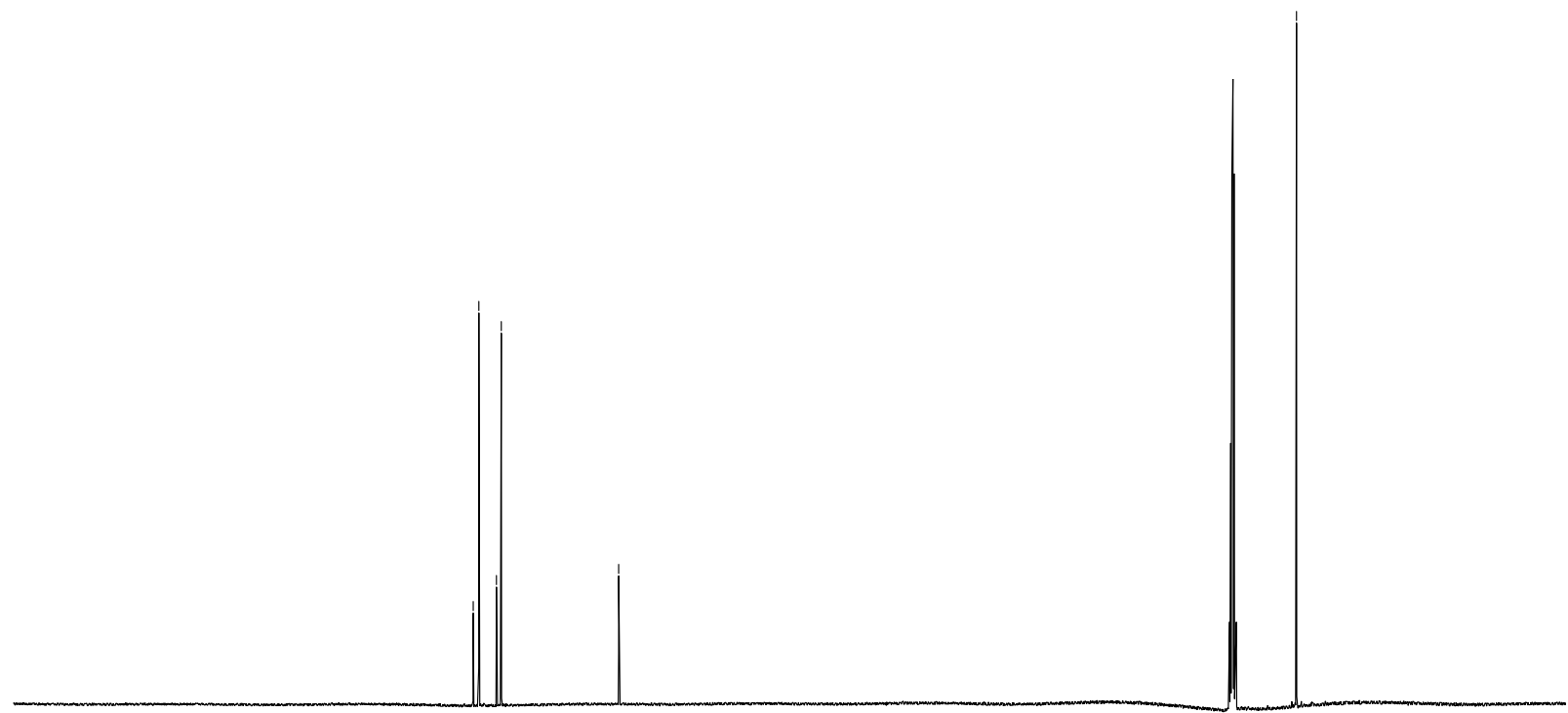

\begin{tabular}{llllllllllllllllllllllllll}
\hline 20 & 210 & 200 & 190 & 180 & 170 & 160 & 150 & 140 & 130 & 120 & $\begin{array}{c}110 \\
\mathrm{f} 1(\mathrm{ppm})\end{array}$ & 100 & 80 & 70 & 60 & 50 & 40 & 30 & 20 & 10 & 0 & 1
\end{tabular} 


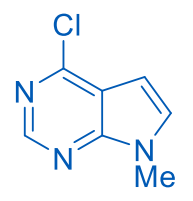

11 $\underbrace{\circ}_{\infty} \quad$ 웃

A (s) \begin{tabular}{l} 
B (d) \\
7.69 \\
\hline
\end{tabular}

7.69
$J(3.6)$ \begin{tabular}{c|}
\hline C (dd) \\
6.58
\end{tabular}

6.58
$\mathrm{~J}(3.5,0.5)$ mై

m m m

D (s) $E(m)$

$3.83 \quad 3.36$
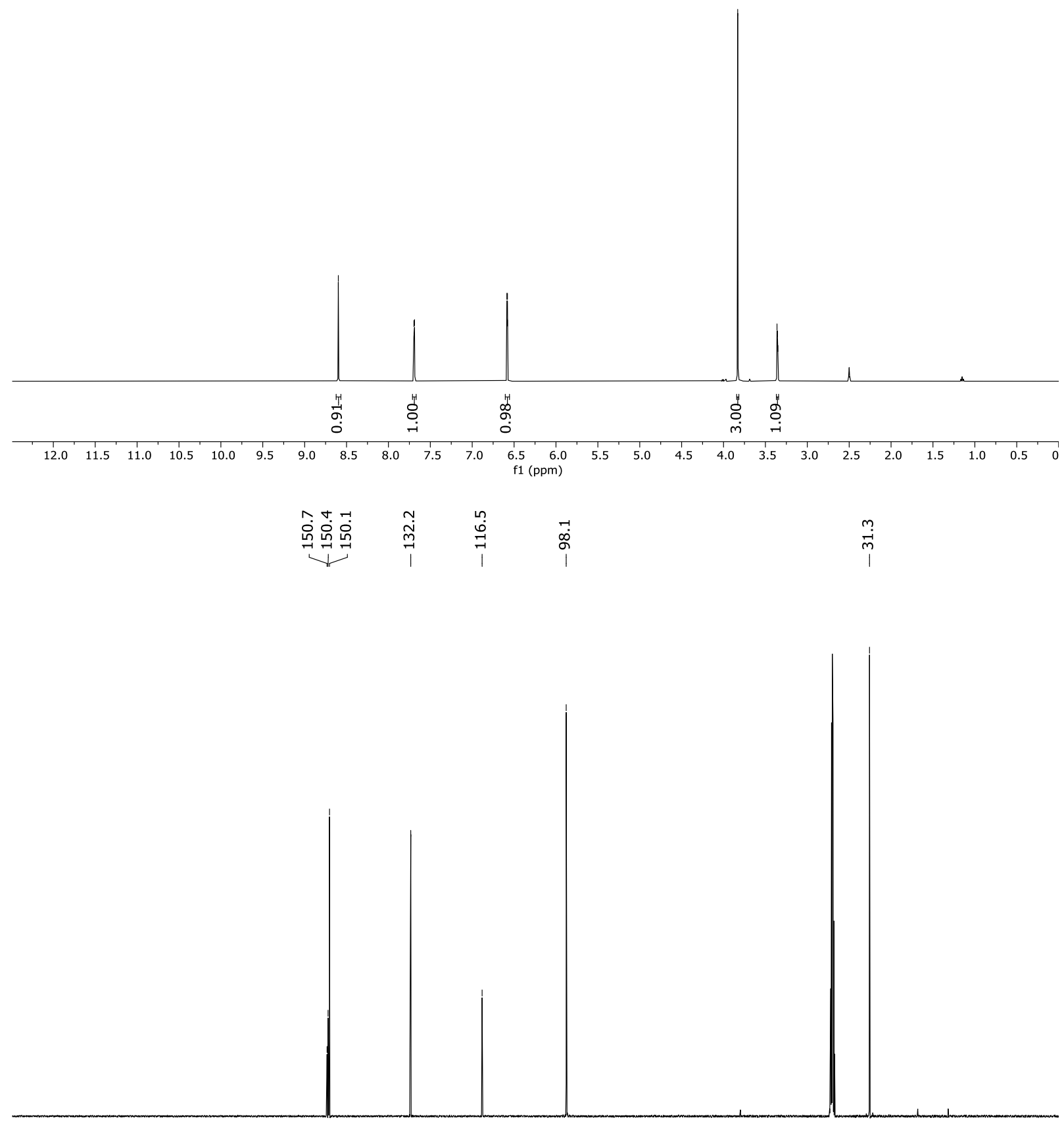

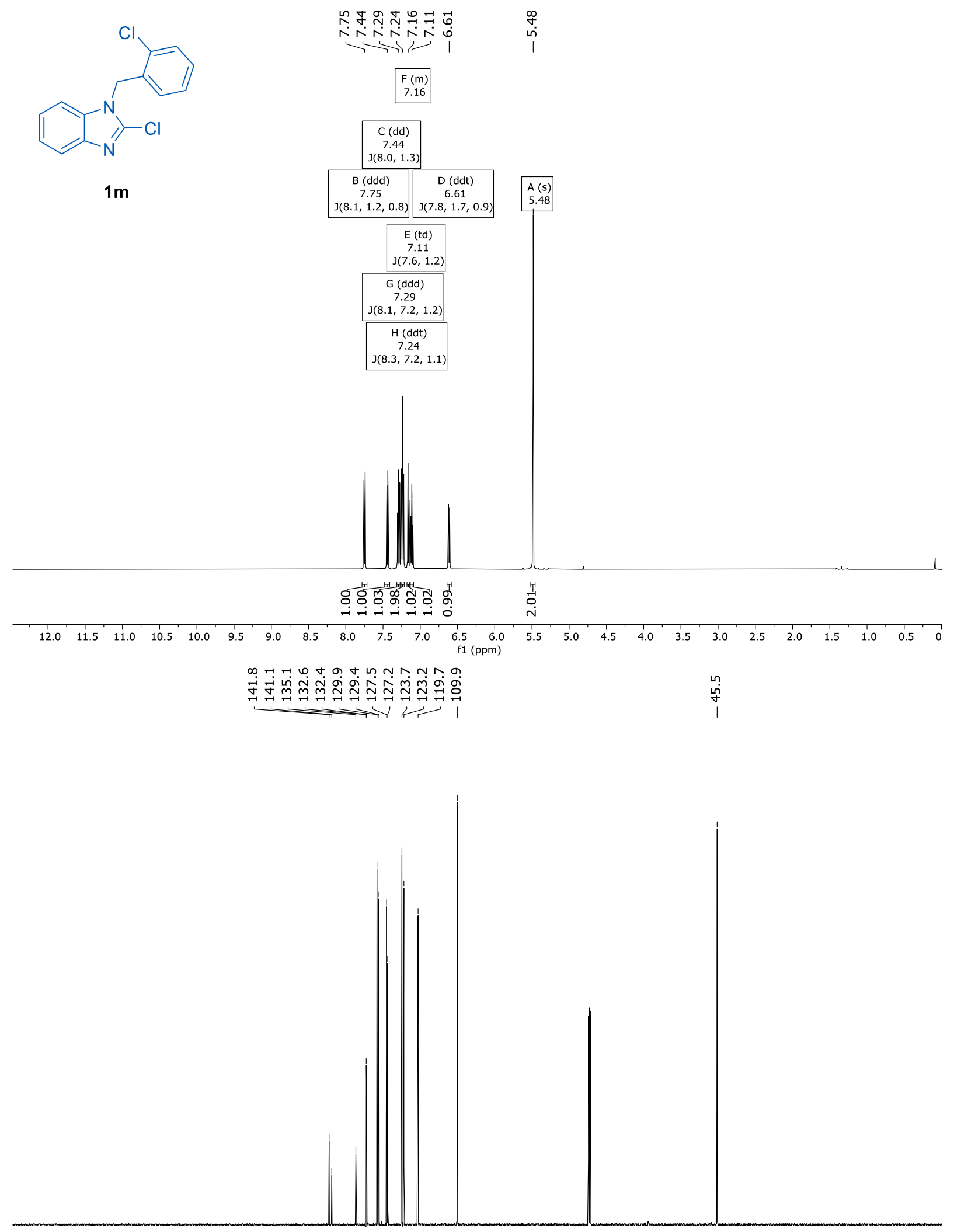

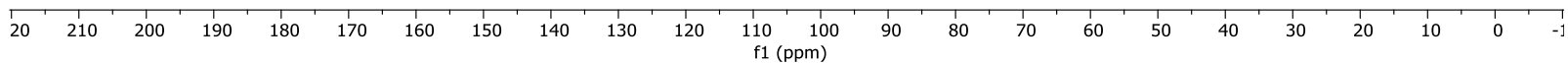



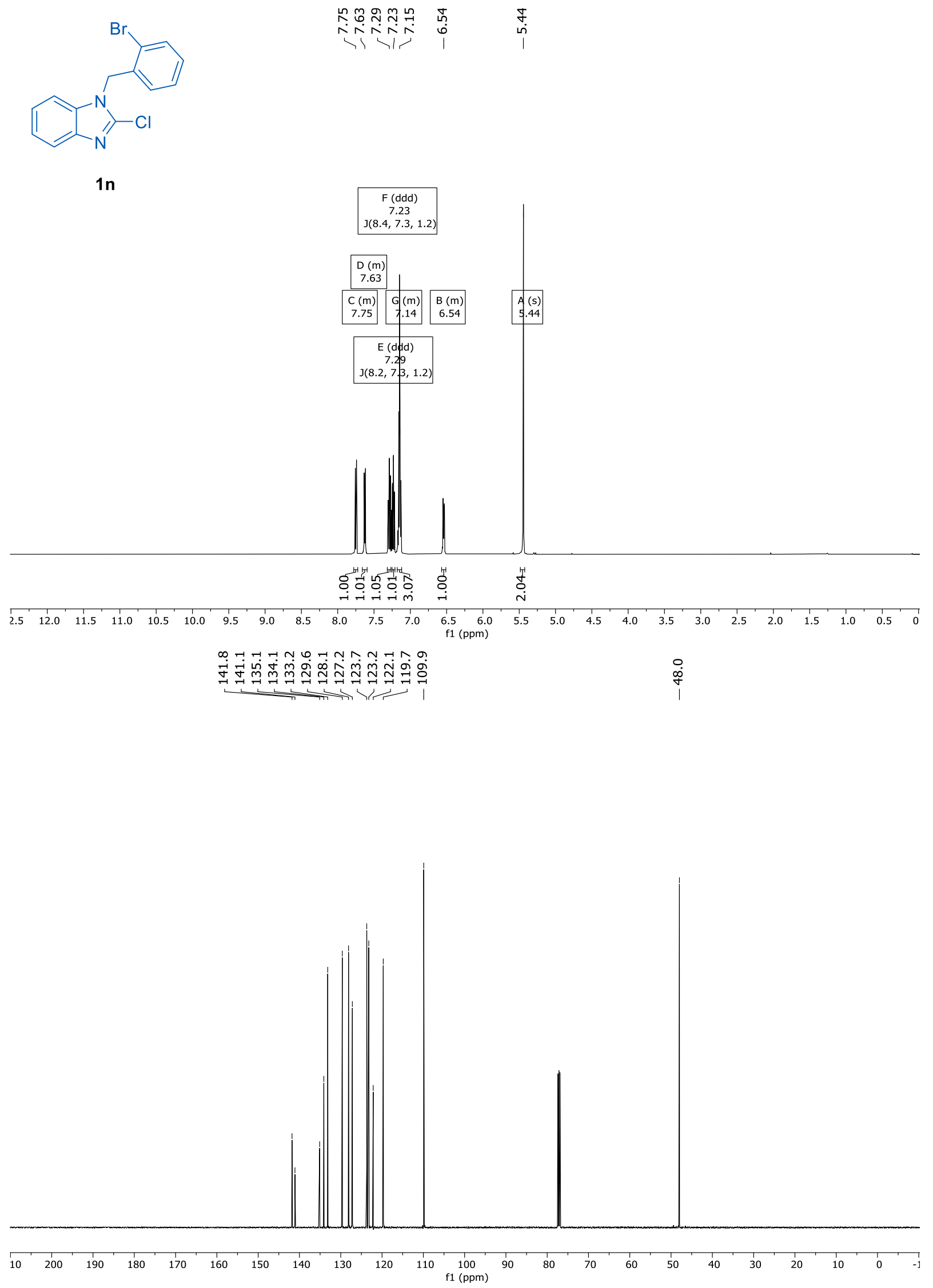
8. NMR Spectra of Aryl Chlorides 

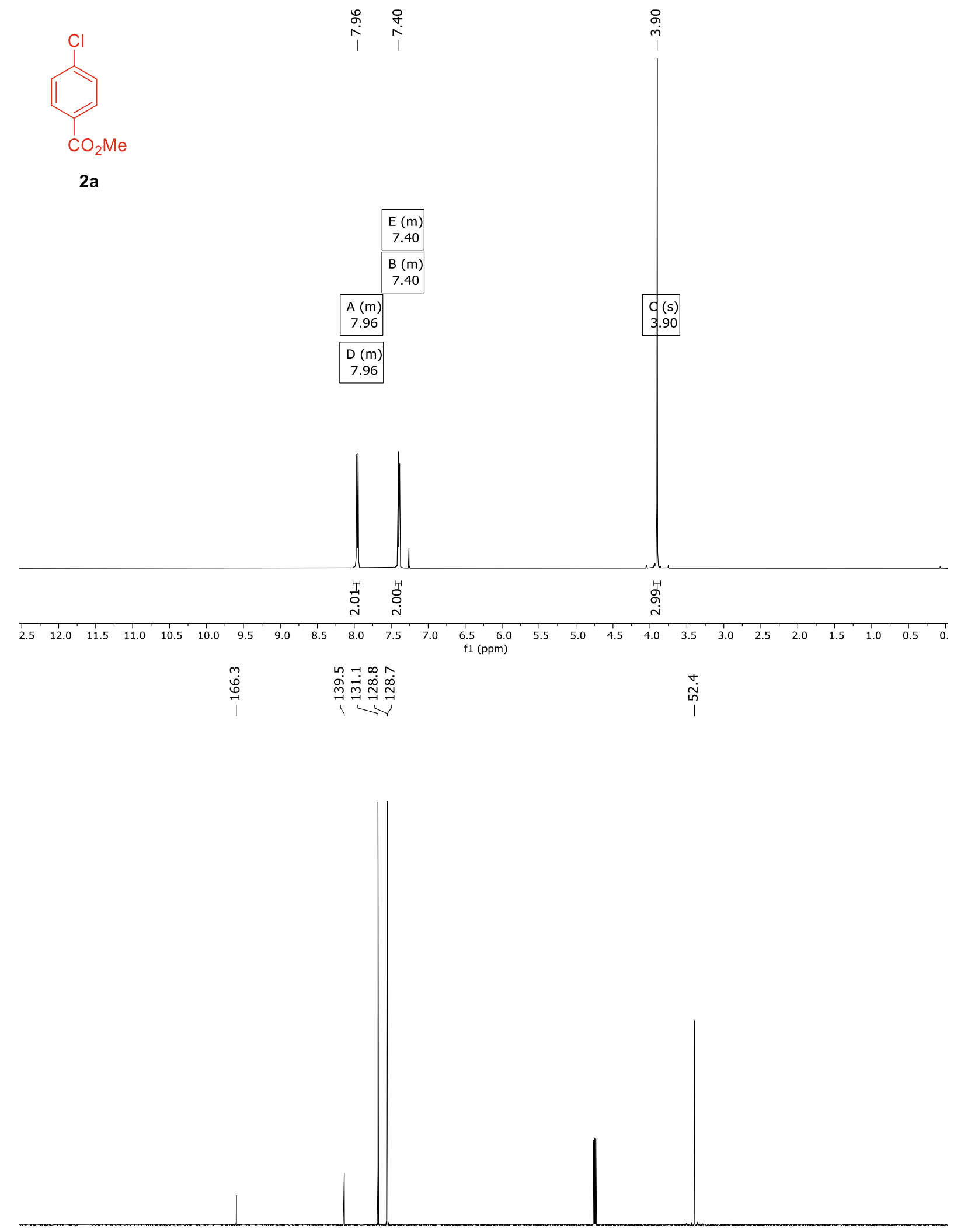

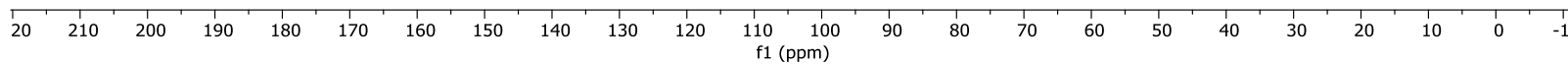



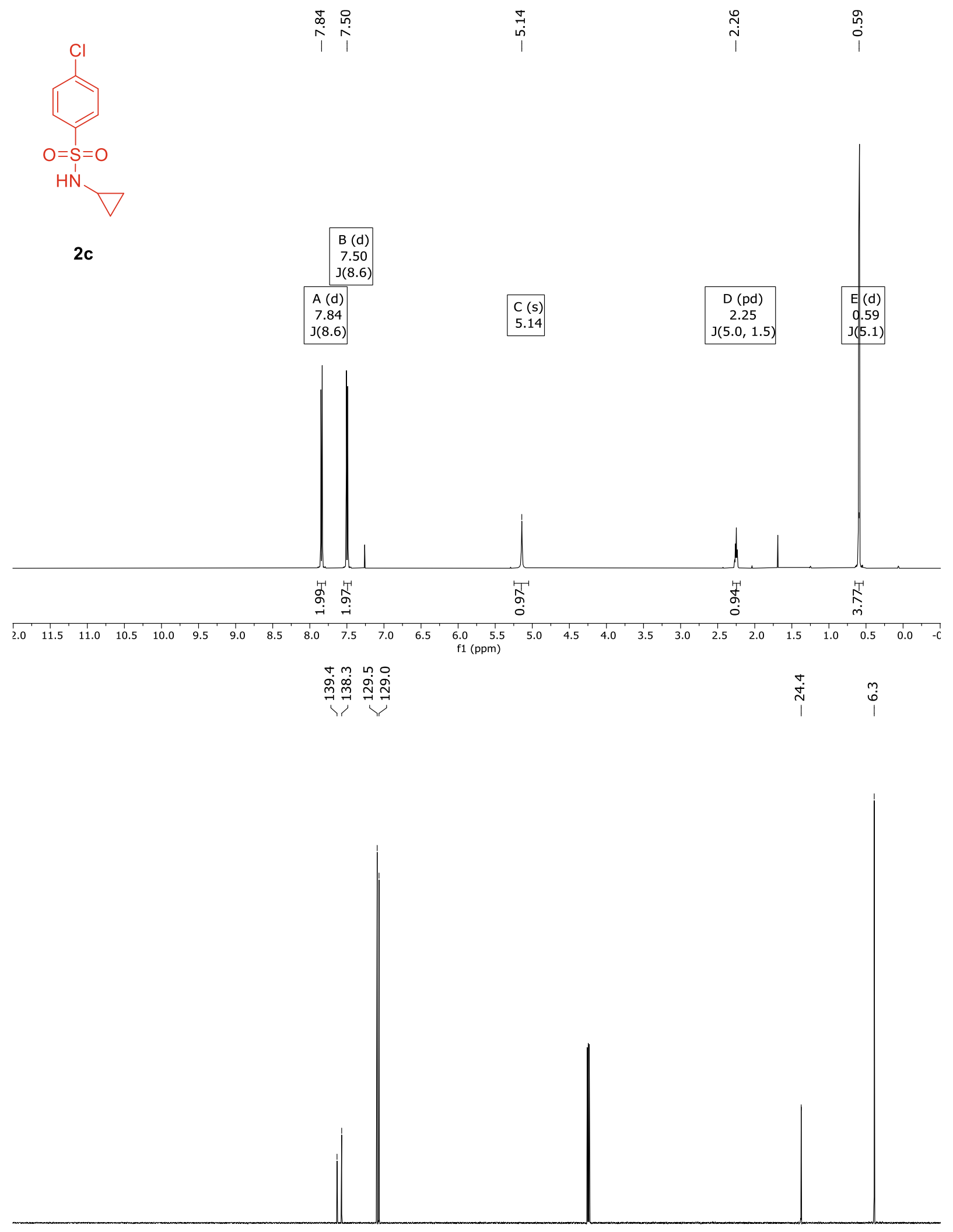

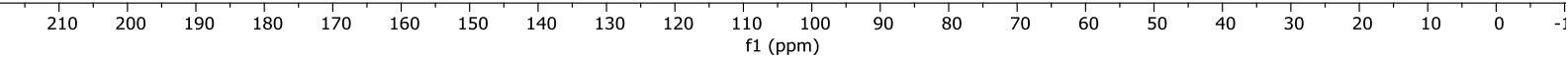




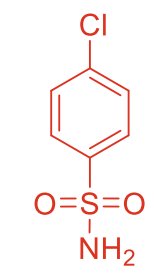

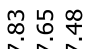

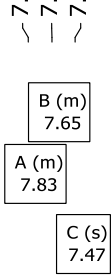

2d

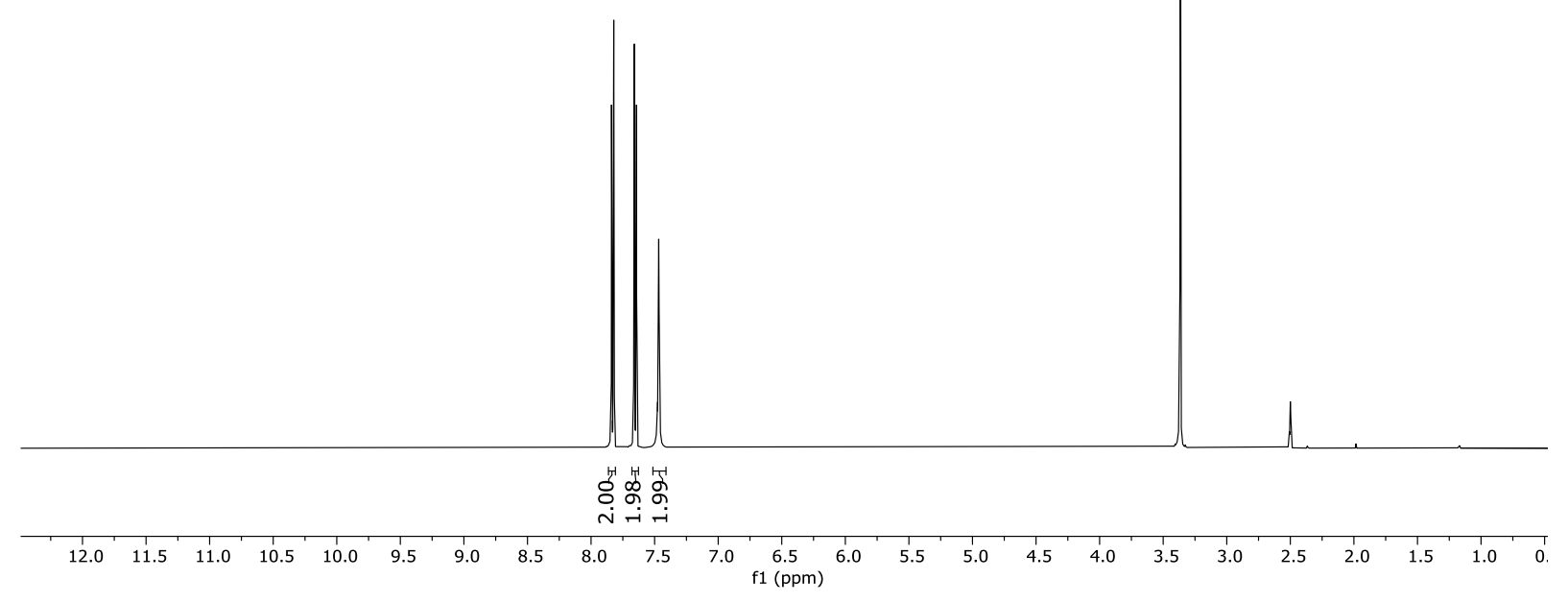

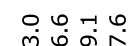

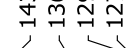

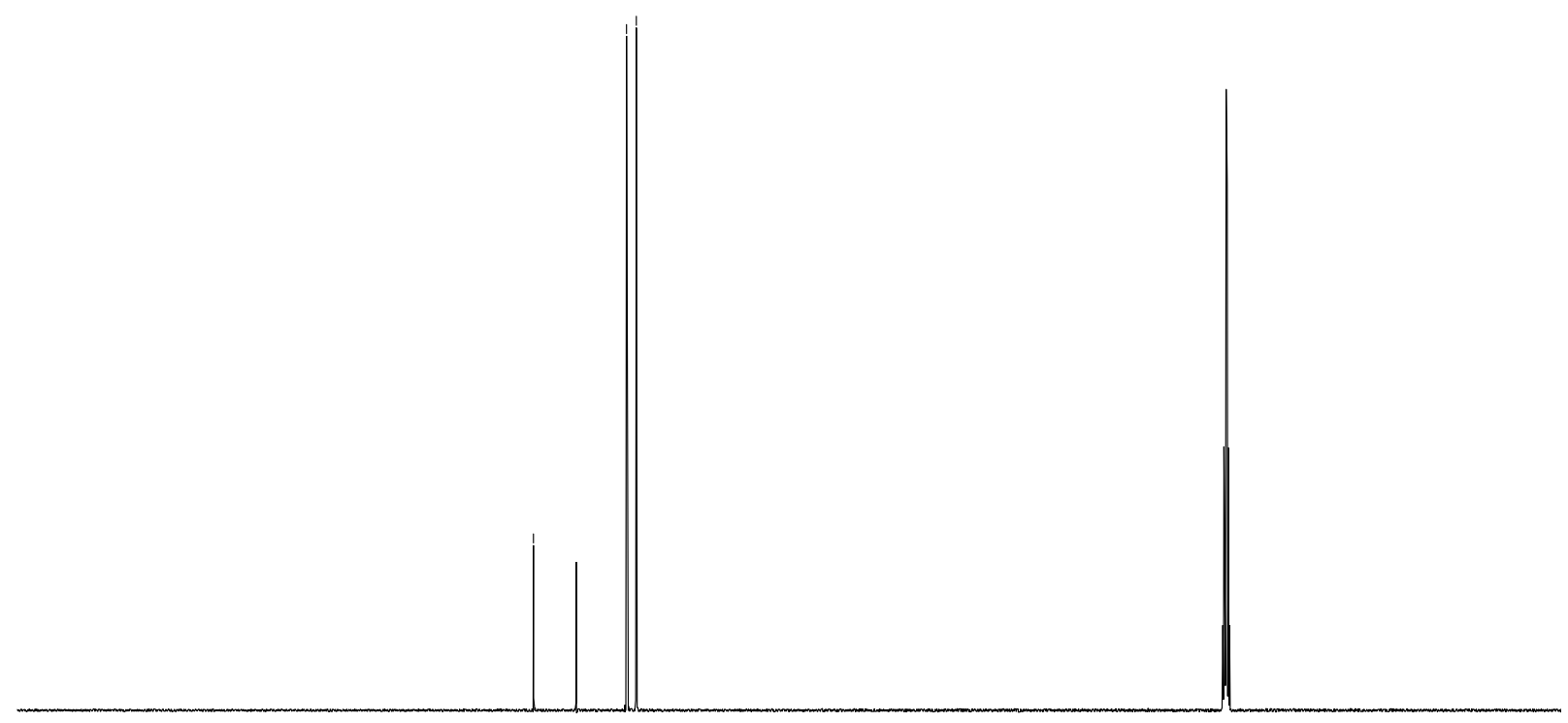

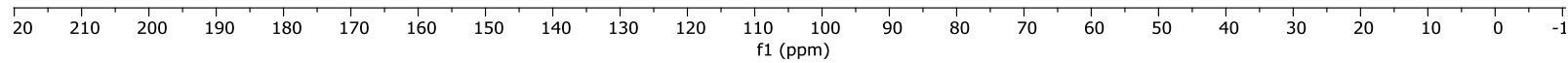




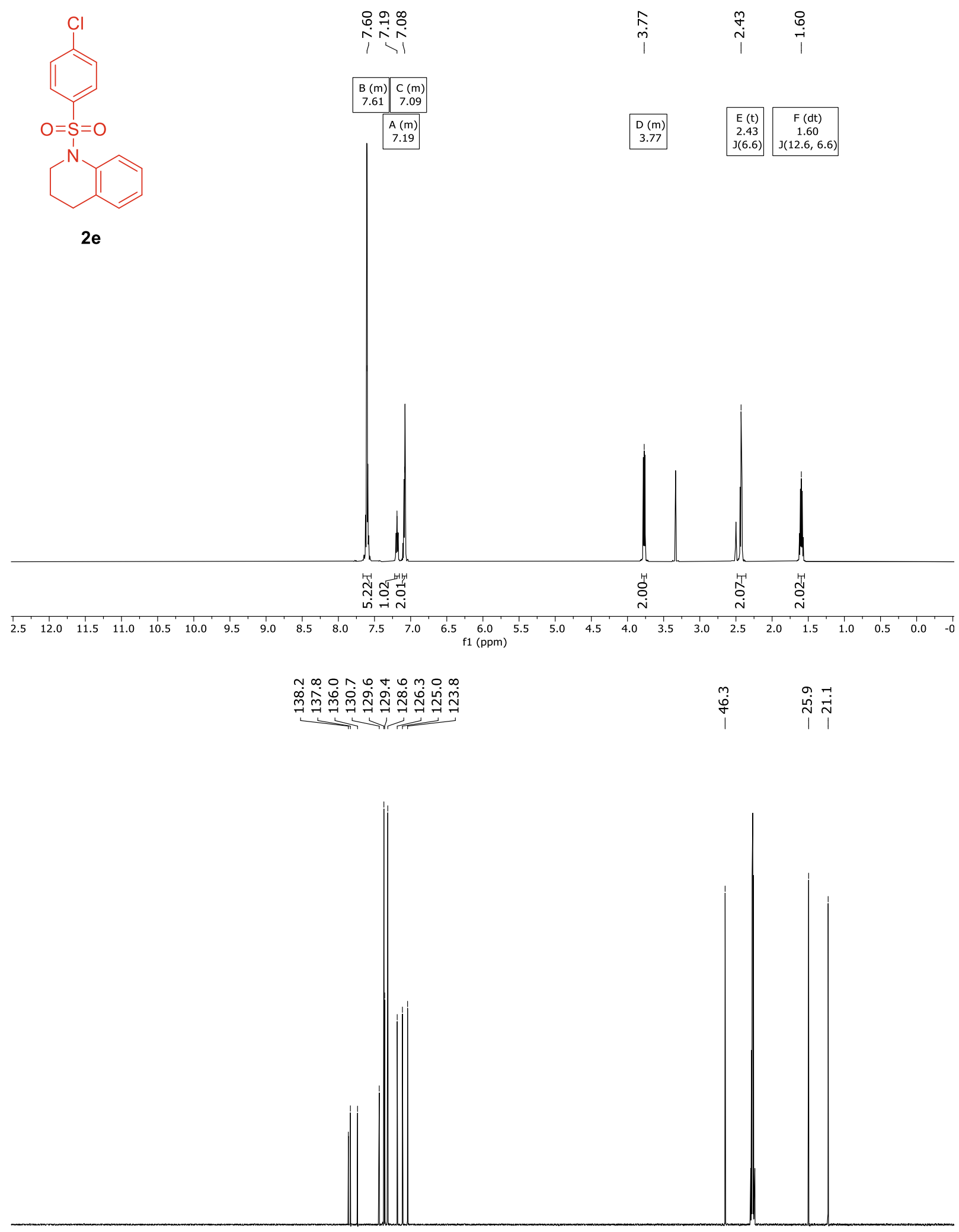

$\begin{array}{llllllllllllllllllllllll}1 & 20 & 210 & 200 & 190 & 180 & 170 & 160 & 150 & 140 & 130 & 120 & \begin{array}{c}110 \\ \mathrm{f} 1(\mathrm{ppm})\end{array} & 100 & 90 & 80 & 70 & 60 & 50 & 40 & 30 & 20 & 10 & 0\end{array}$ 


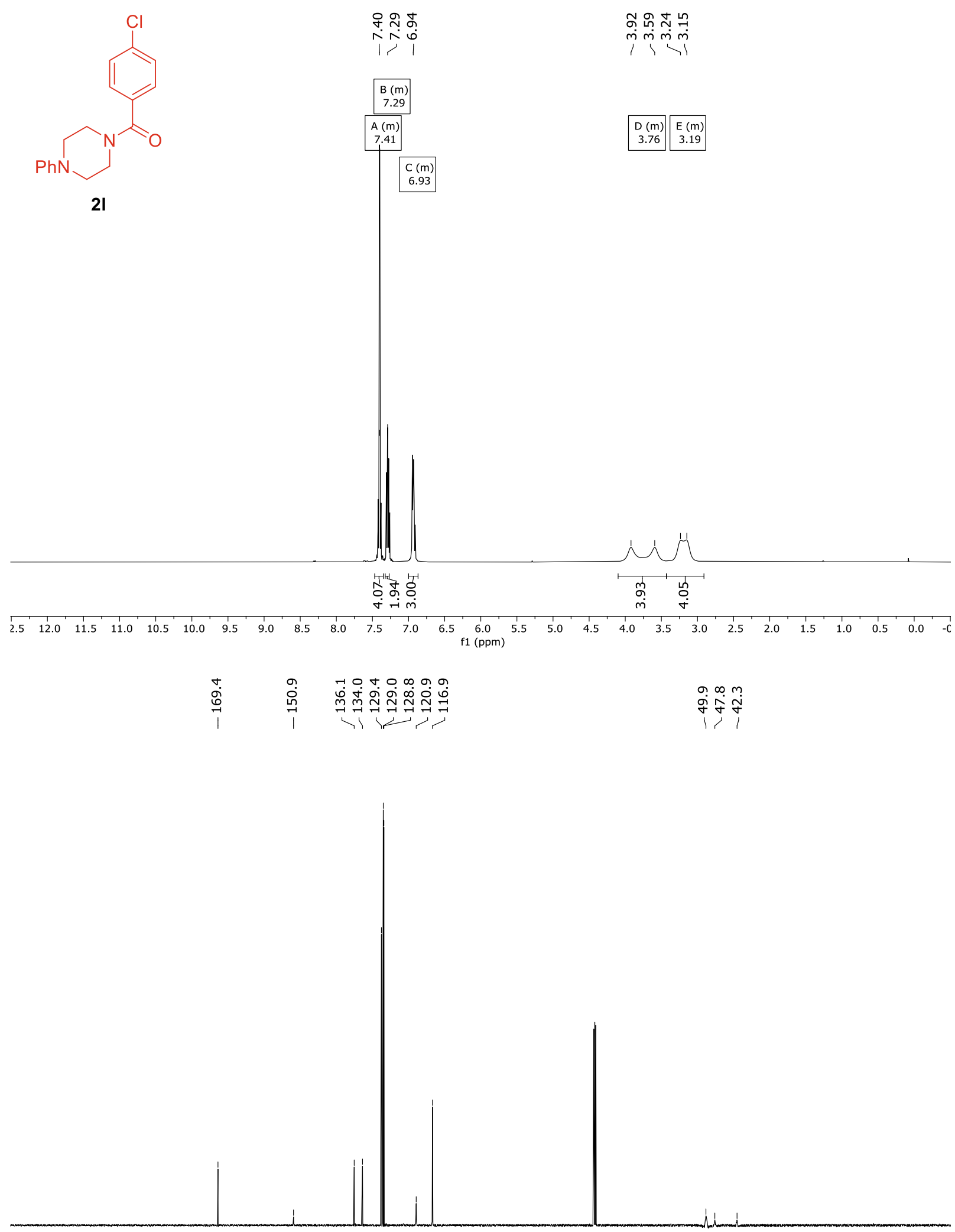

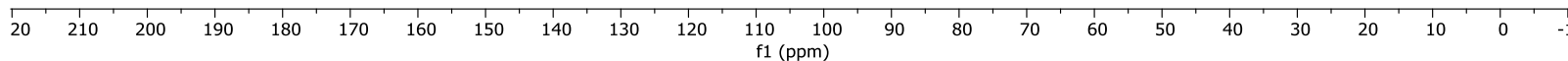



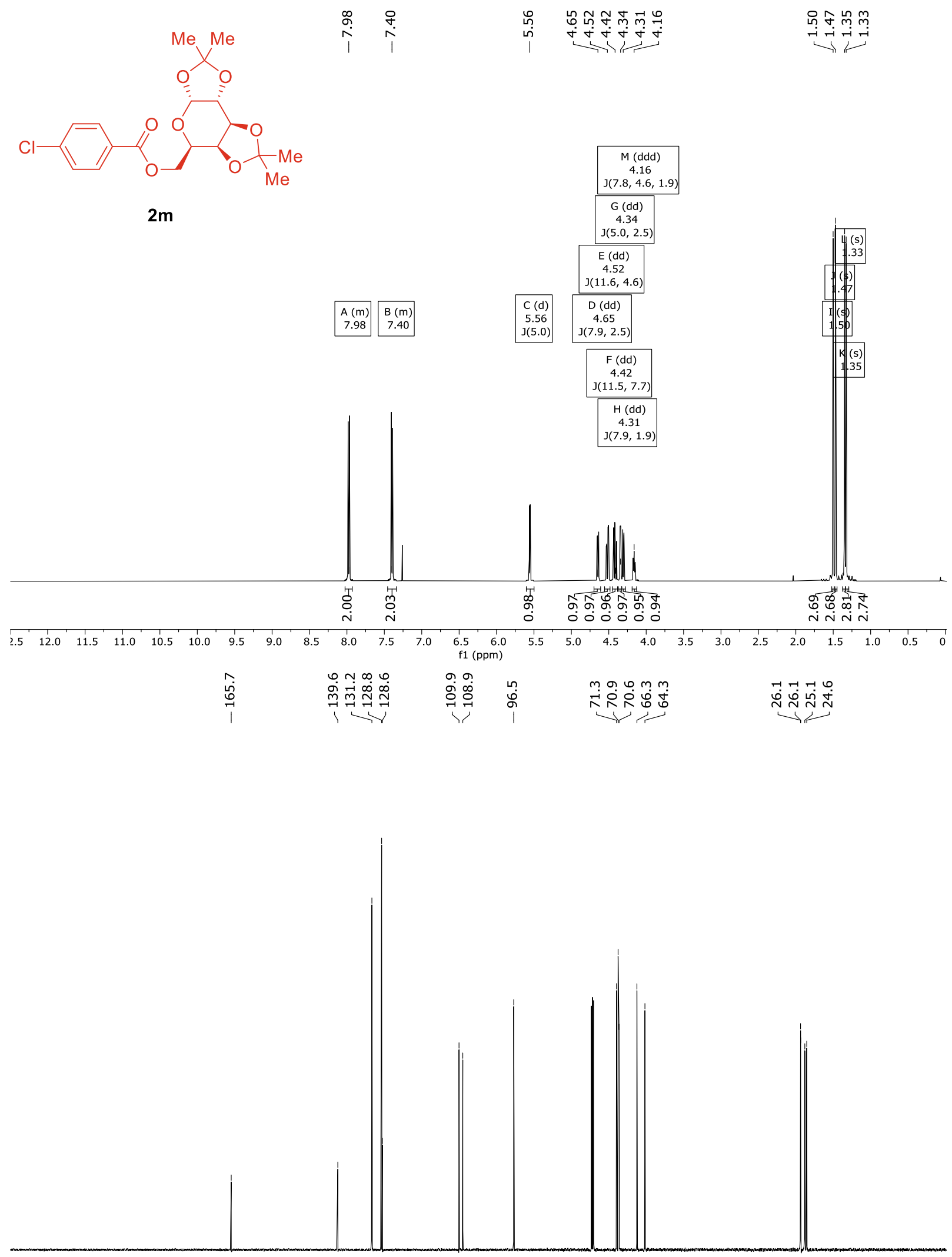

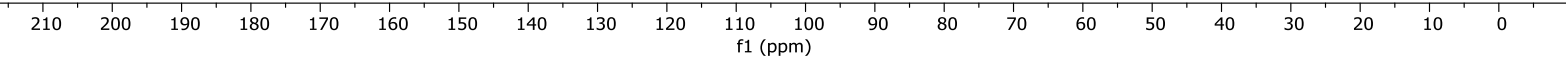


9. NMR Spectra of Products 

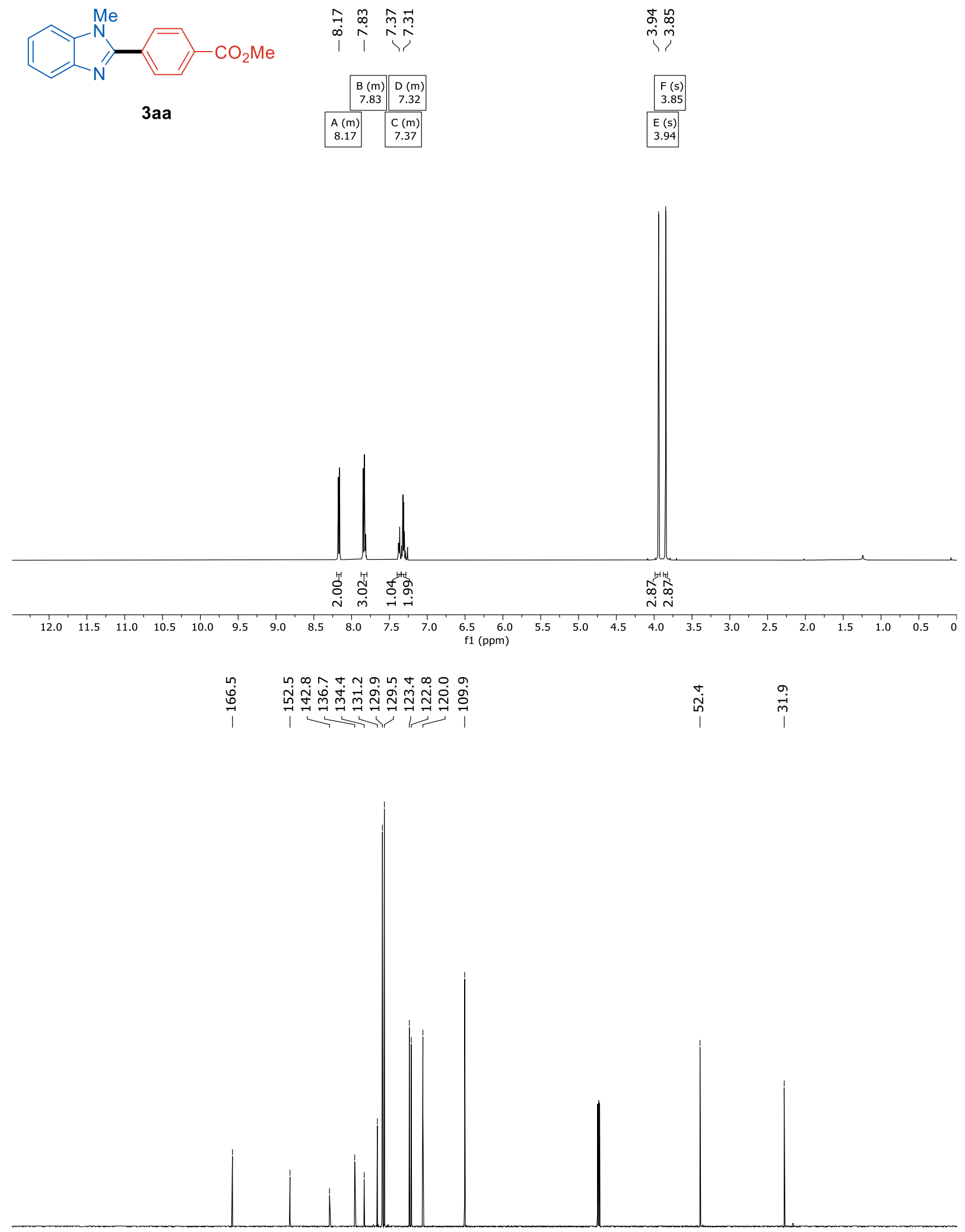

20

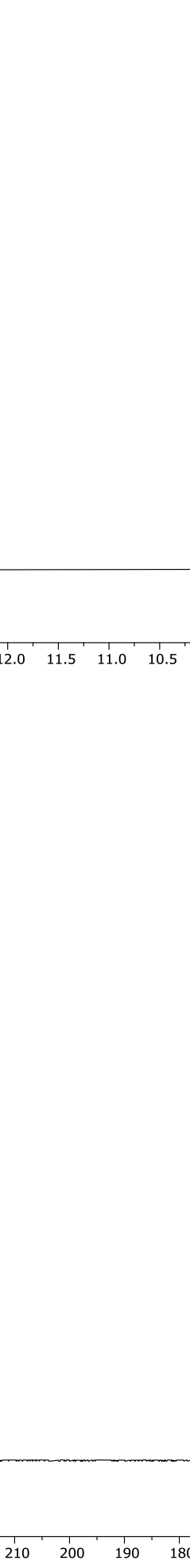

$210 \quad 200$
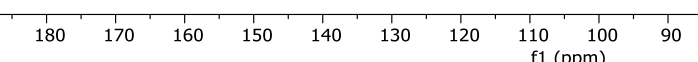

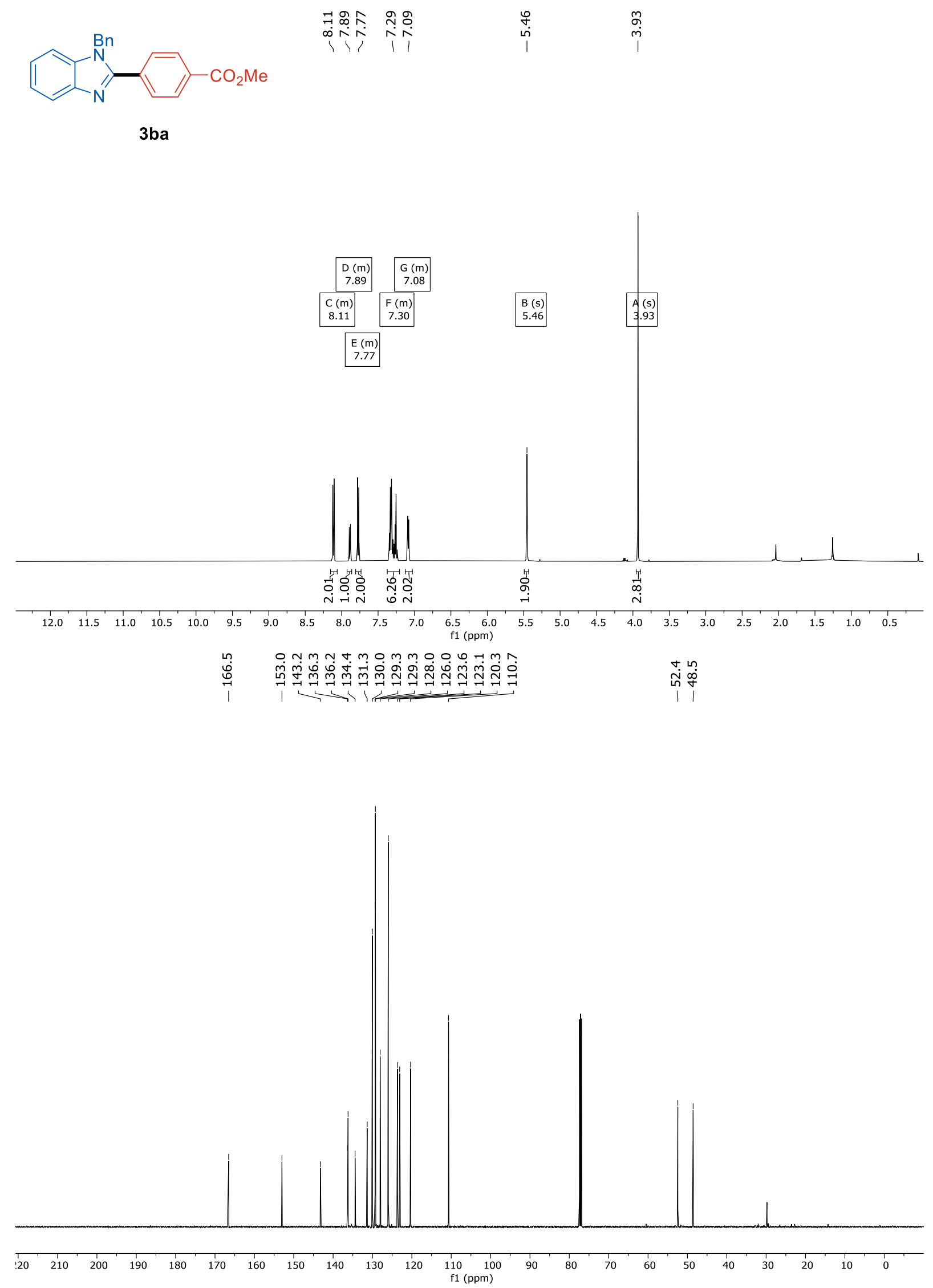

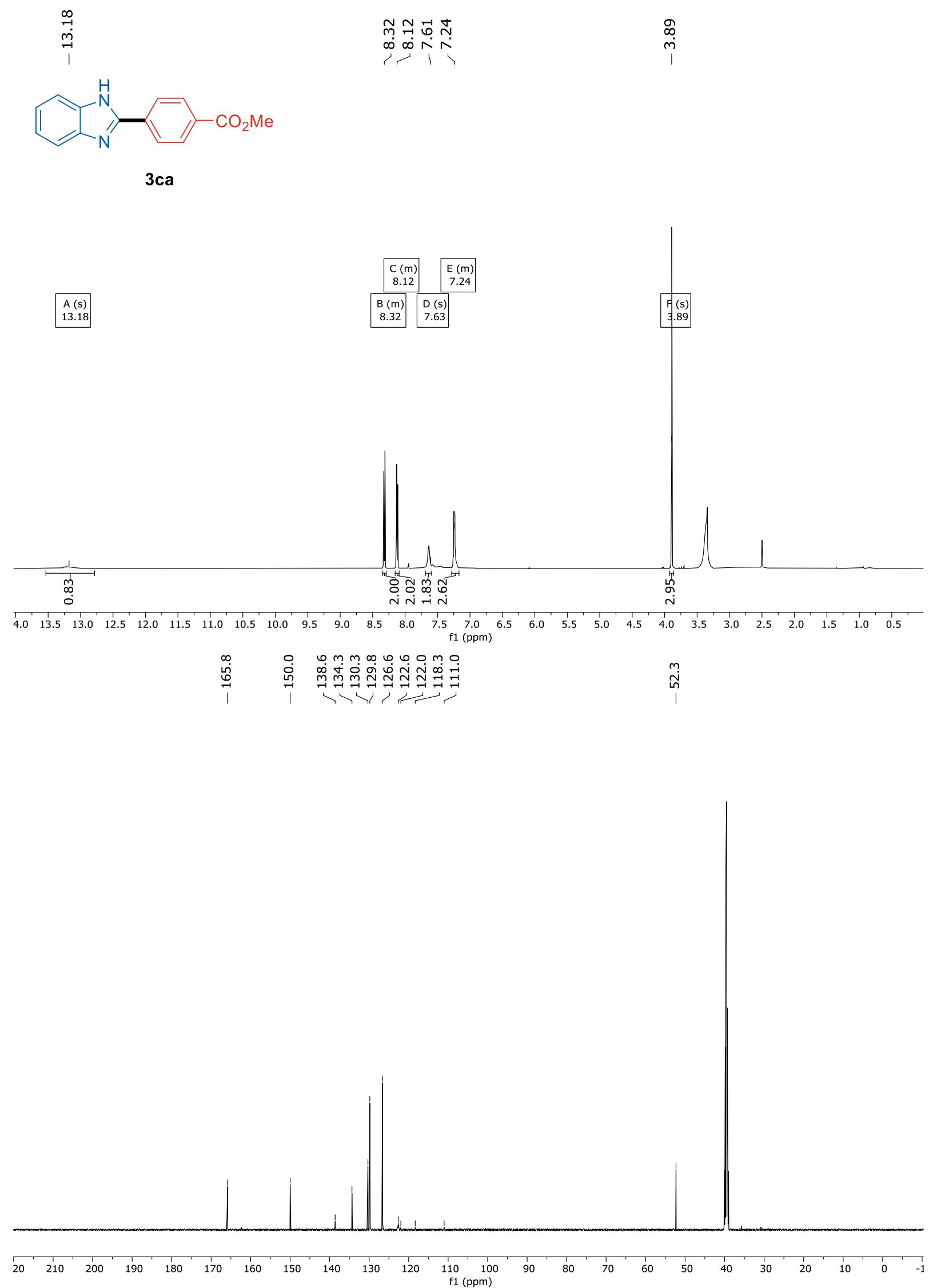

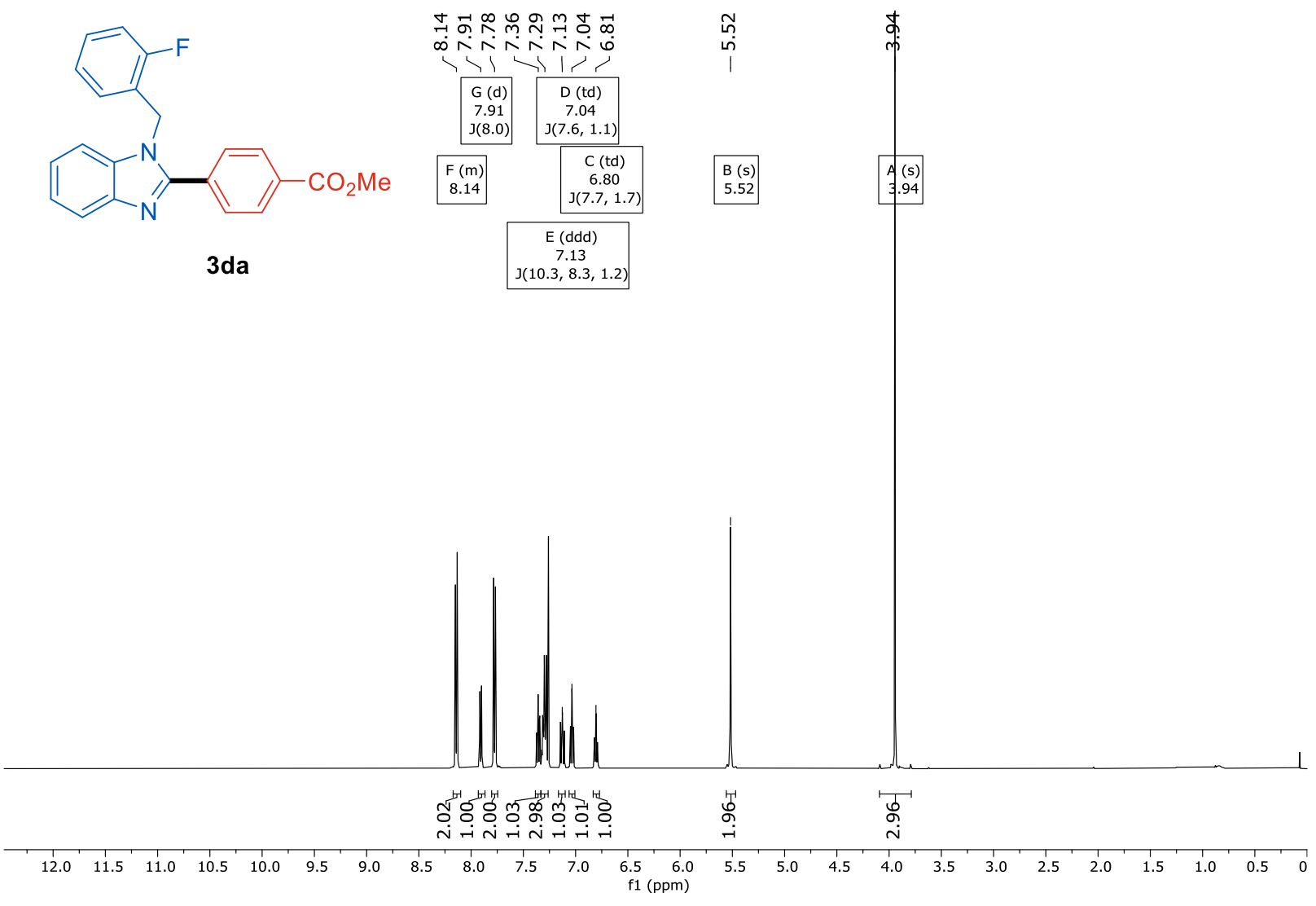

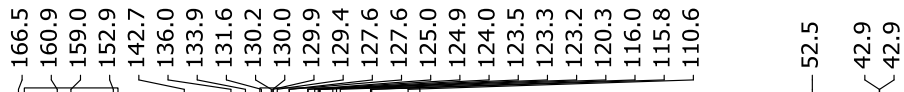

\begin{tabular}{|c|c|c|c|}
\hline $\begin{array}{c}Q(d) \\
159.96 \\
J(246.80)\end{array}$ & & \begin{tabular}{l|c} 
(d) & D \\
7.63 & 115 \\
$3.53)$ & $\mathrm{J}(20$ \\
\end{tabular} & $\begin{array}{c}D(d) \\
115.87 \\
J(20.64)\end{array}$ \\
\hline \multirow[t]{3}{*}{$\begin{array}{c}P(s) \\
152.89\end{array}$} & $\begin{array}{c}\mathrm{O}(\mathrm{s}) \\
136.00\end{array}$ & $\begin{array}{c}F(d) \\
123.24 \\
J(14.08)\end{array}$ & $\begin{array}{c}C(\mathrm{~s}) \\
110.56\end{array}$ \\
\hline & $\begin{array}{r}M(s) \\
131.6\end{array}$ & \begin{tabular}{l|l}
$E(s)$ \\
120.30
\end{tabular} & \\
\hline & $\begin{array}{c}R(s) \\
133.92\end{array}$ & \begin{tabular}{c|}
$\mathrm{G}(\mathrm{s})$ \\
123.46
\end{tabular} & \\
\hline
\end{tabular}




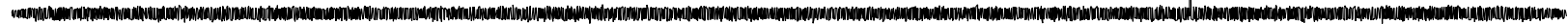

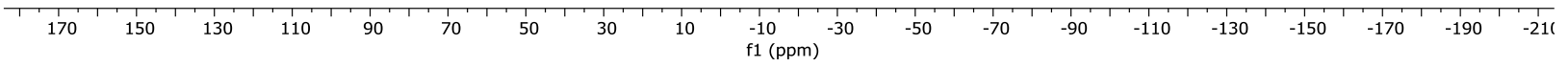




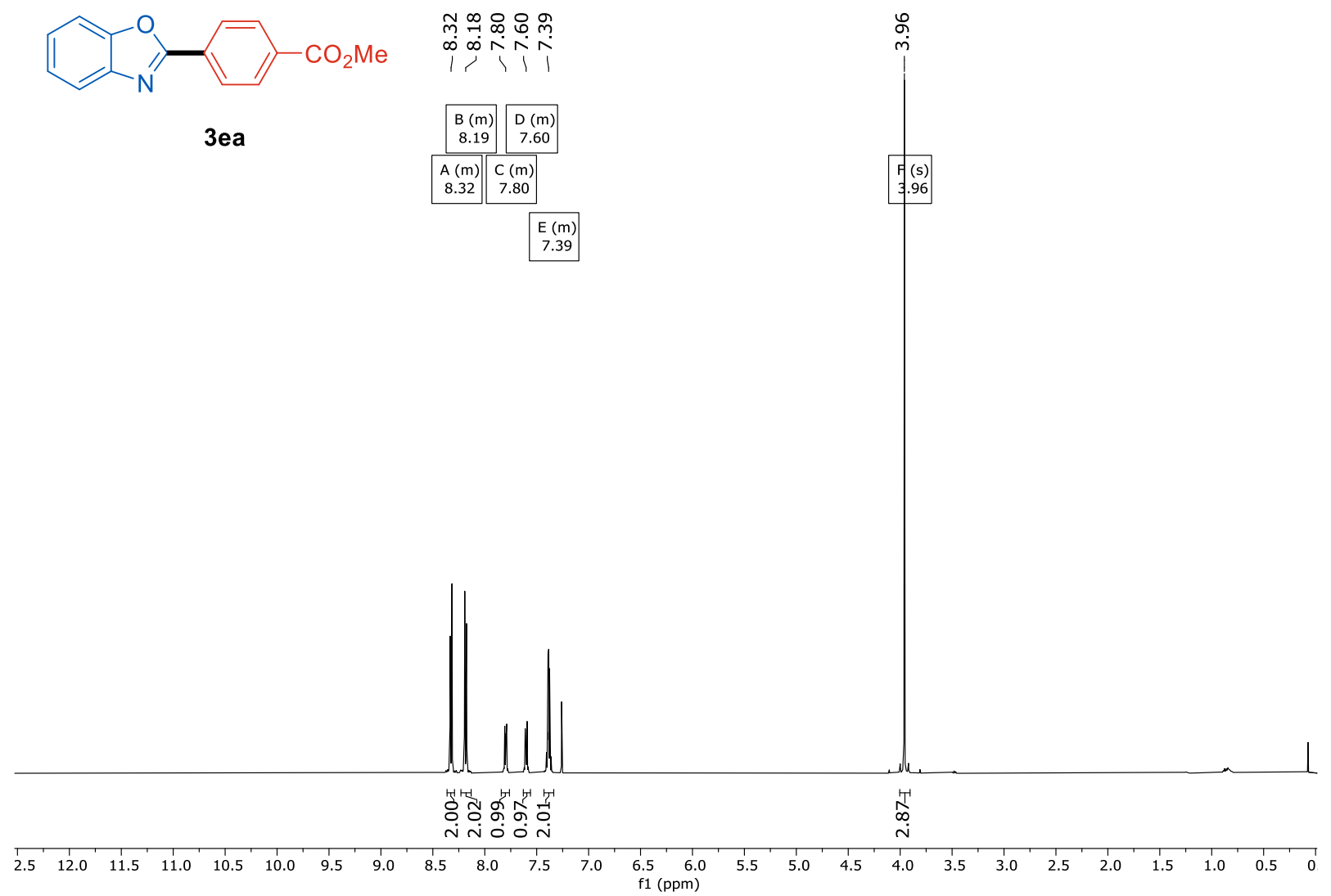

站

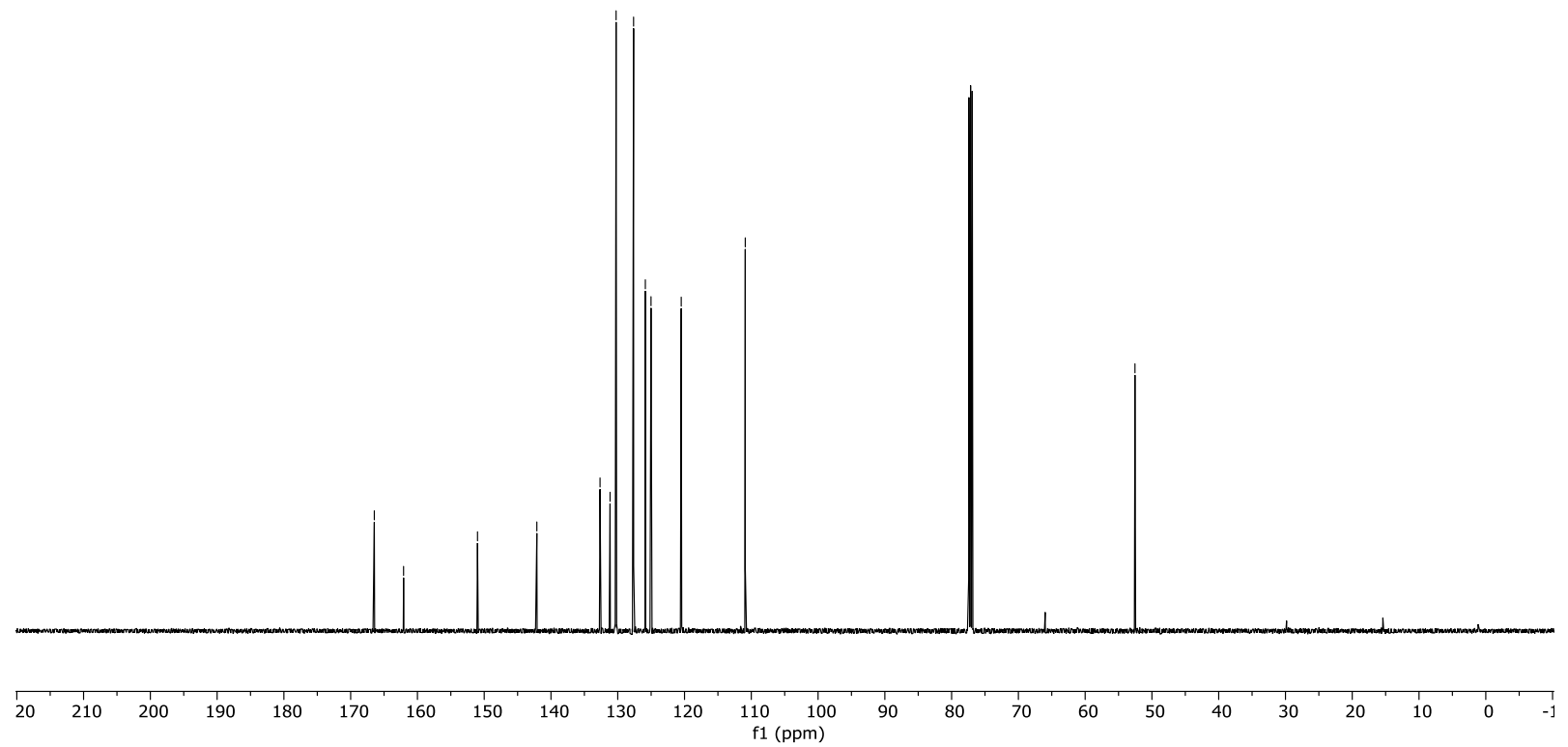



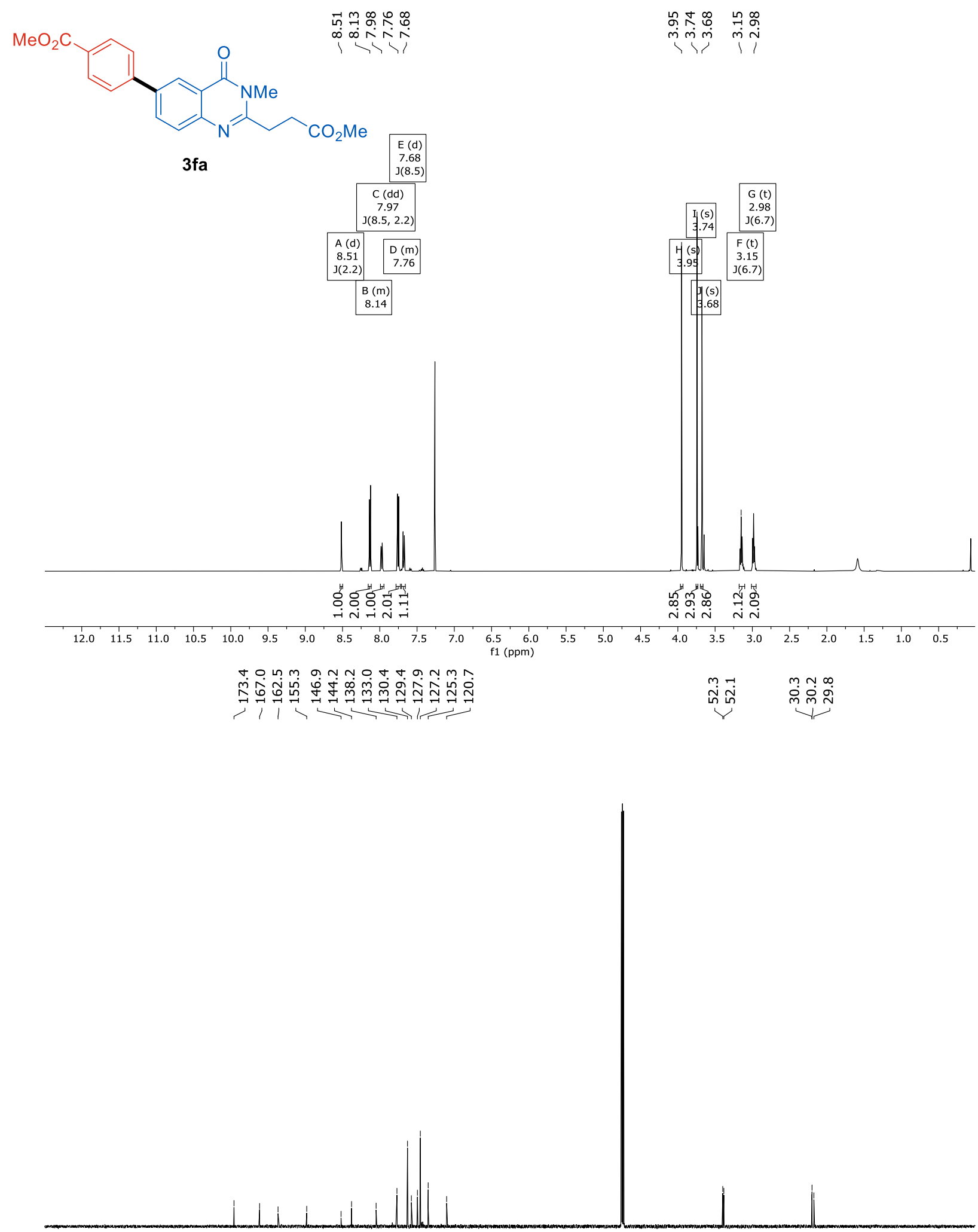

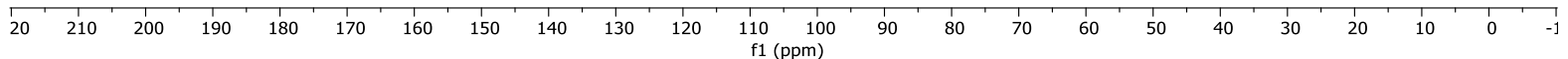



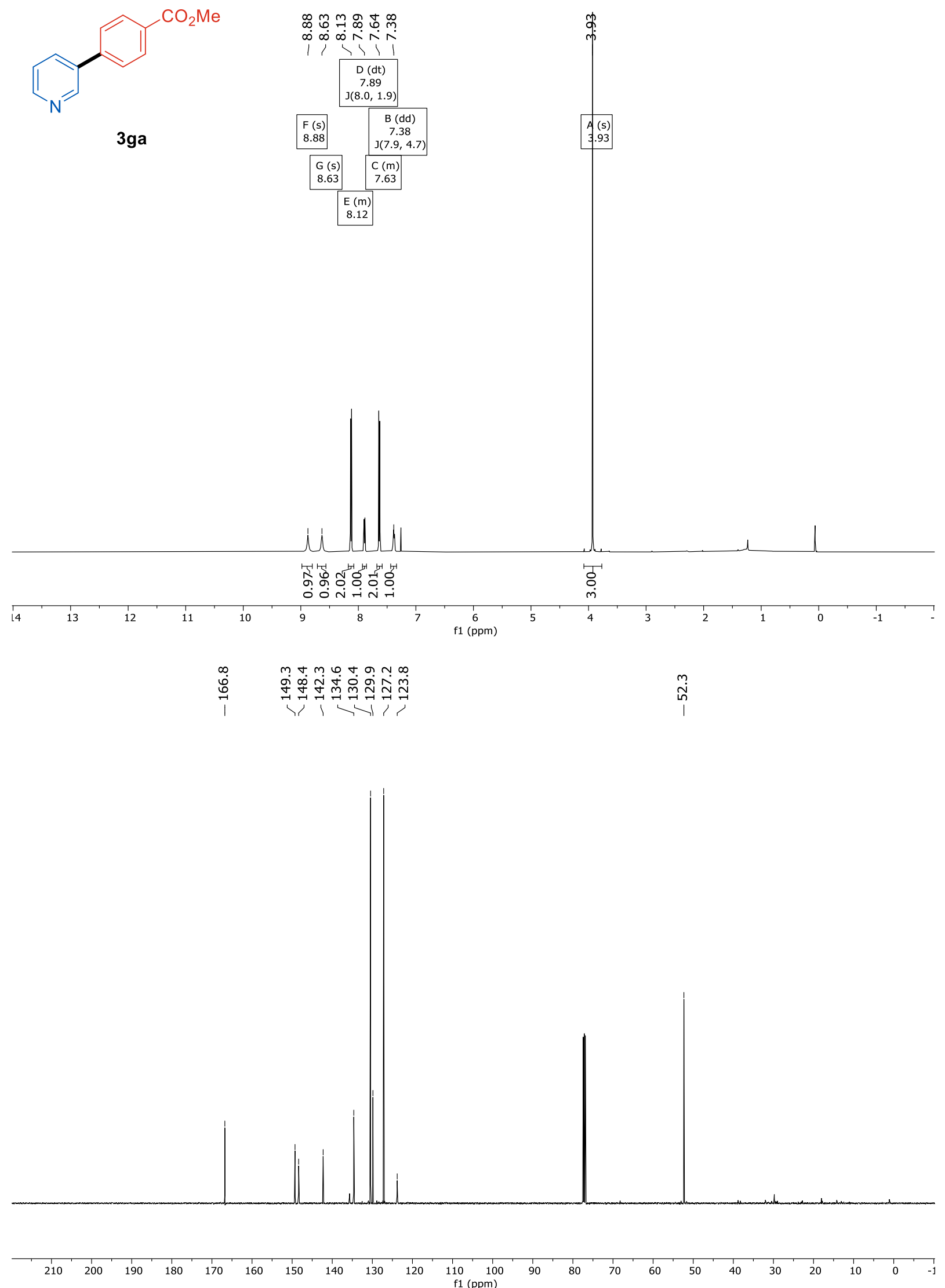

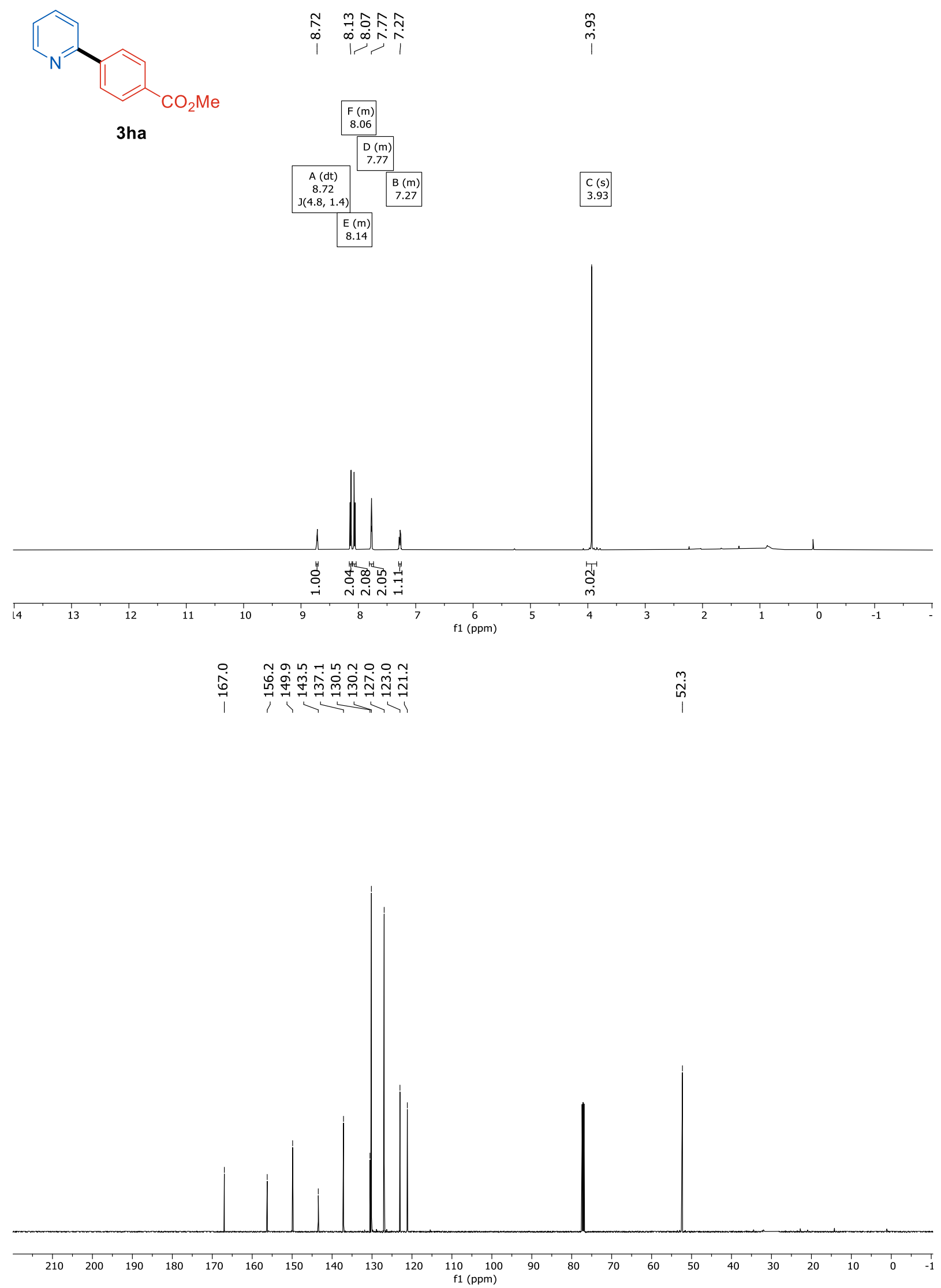

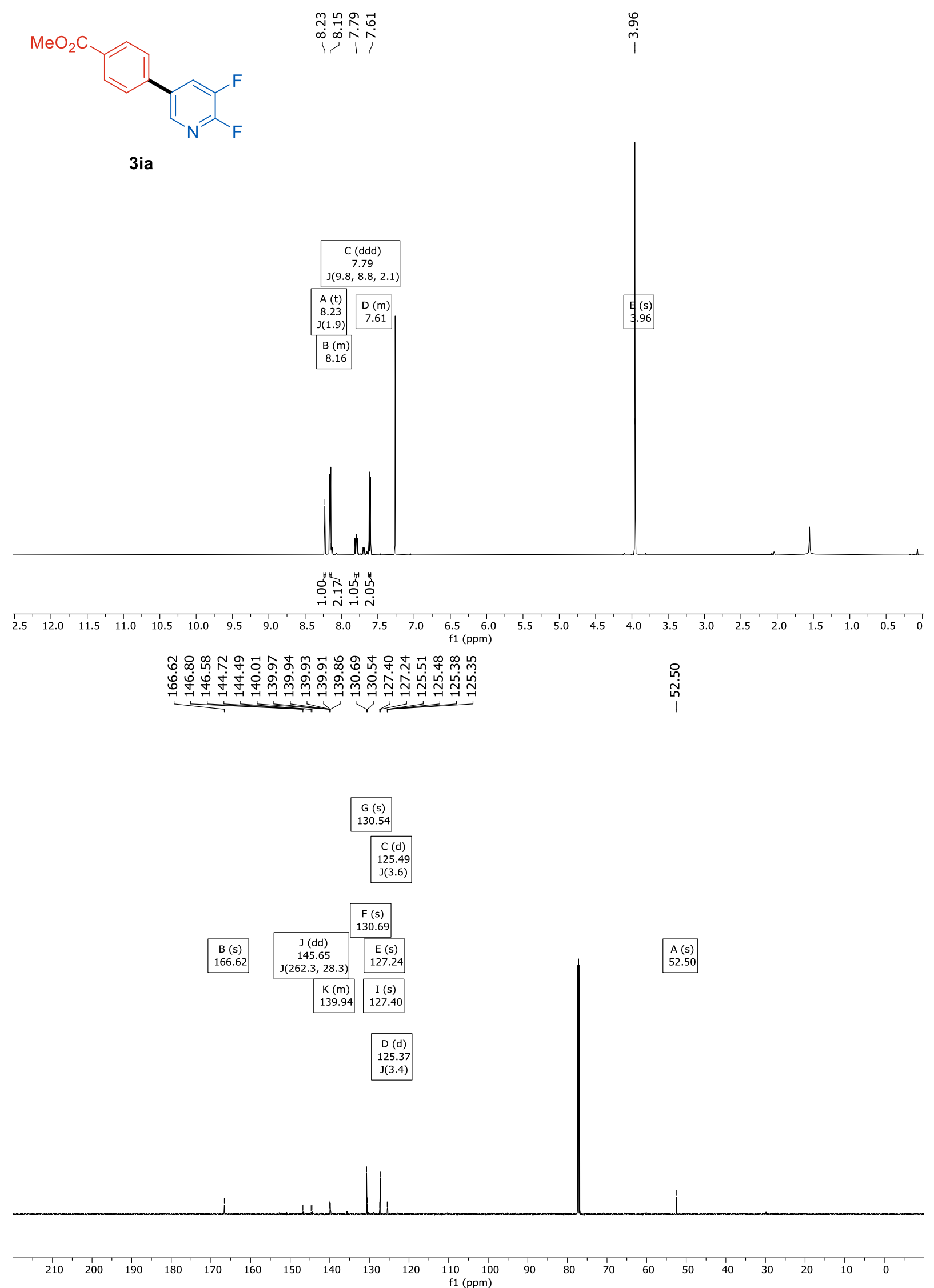


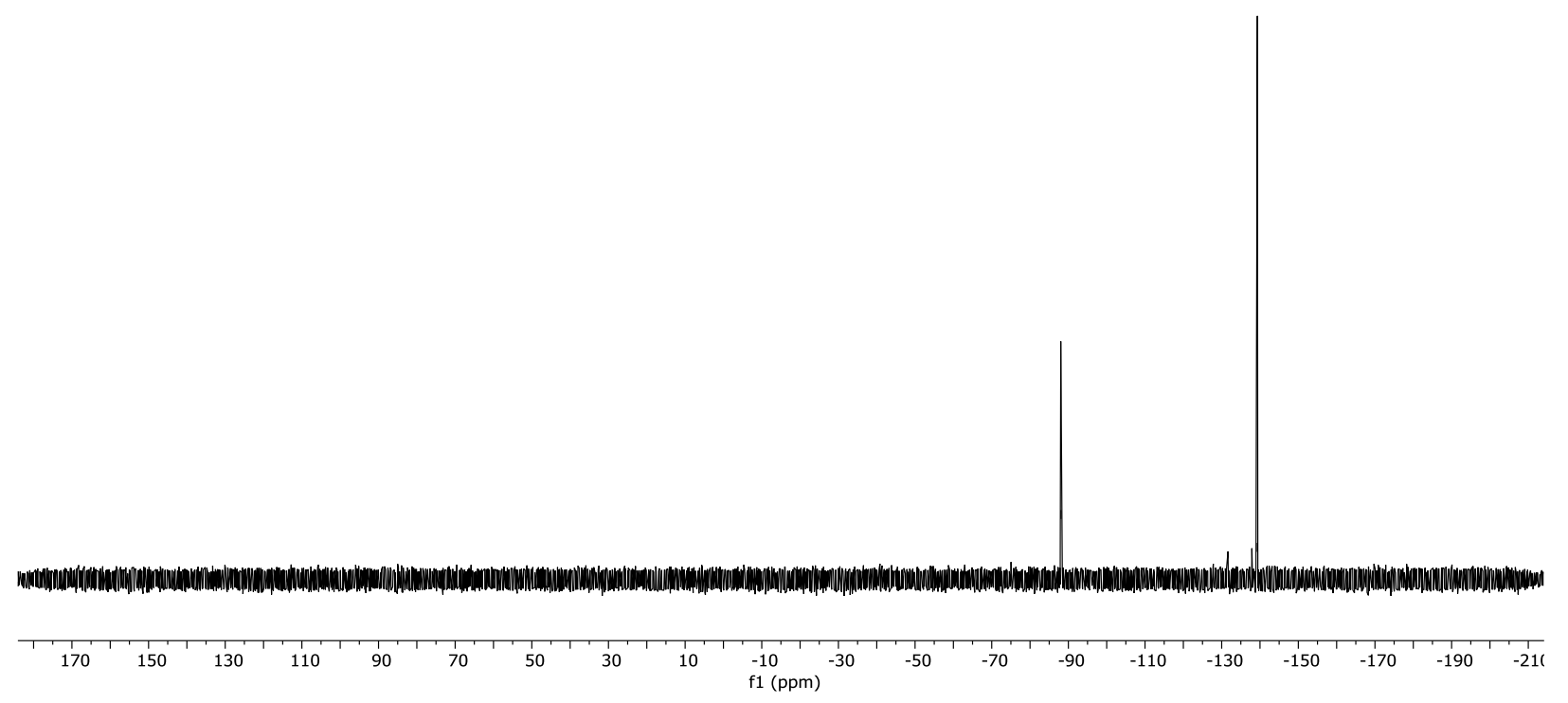



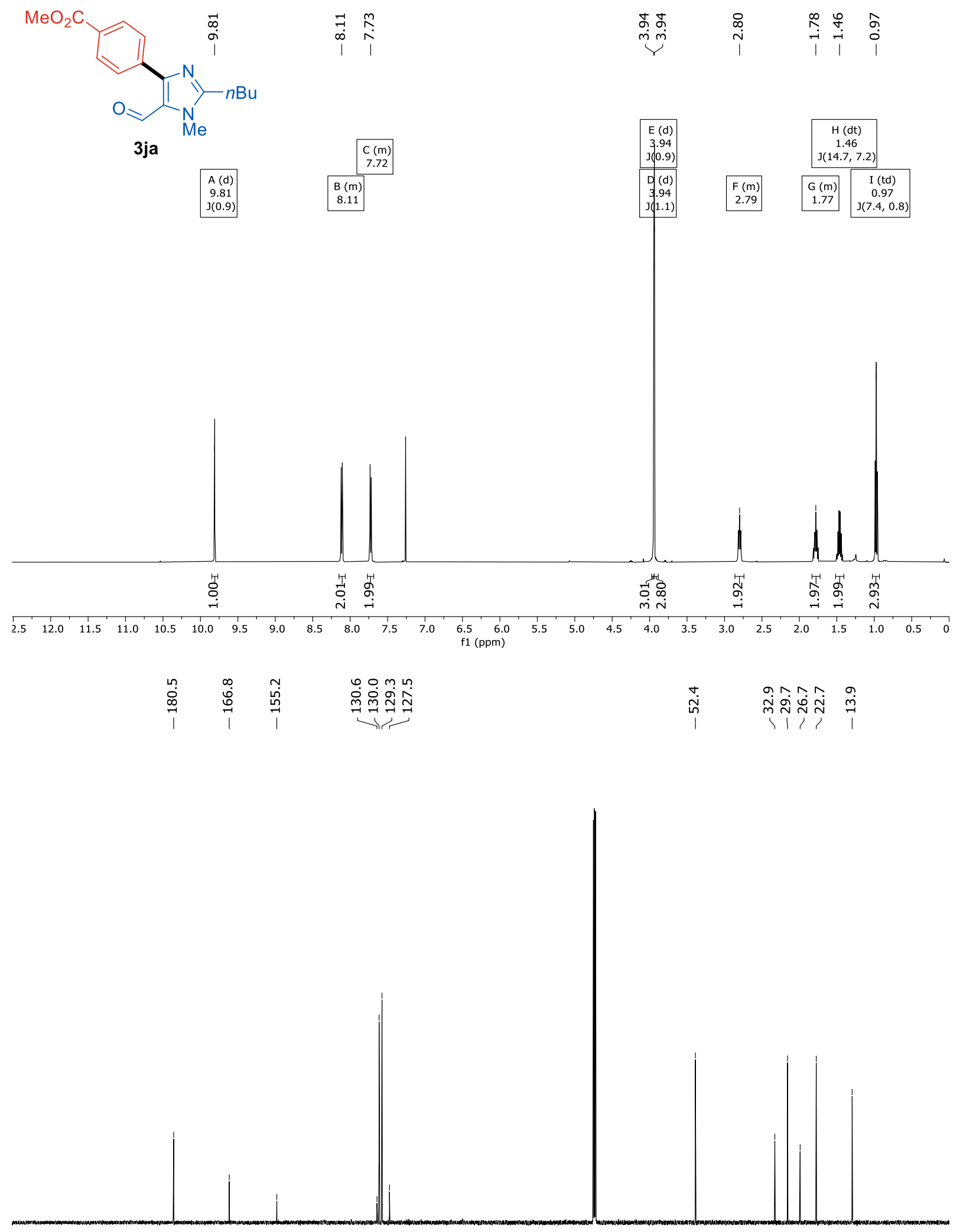

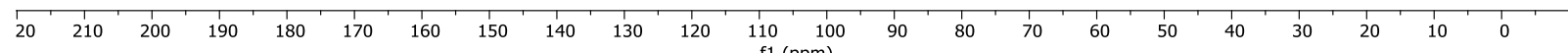




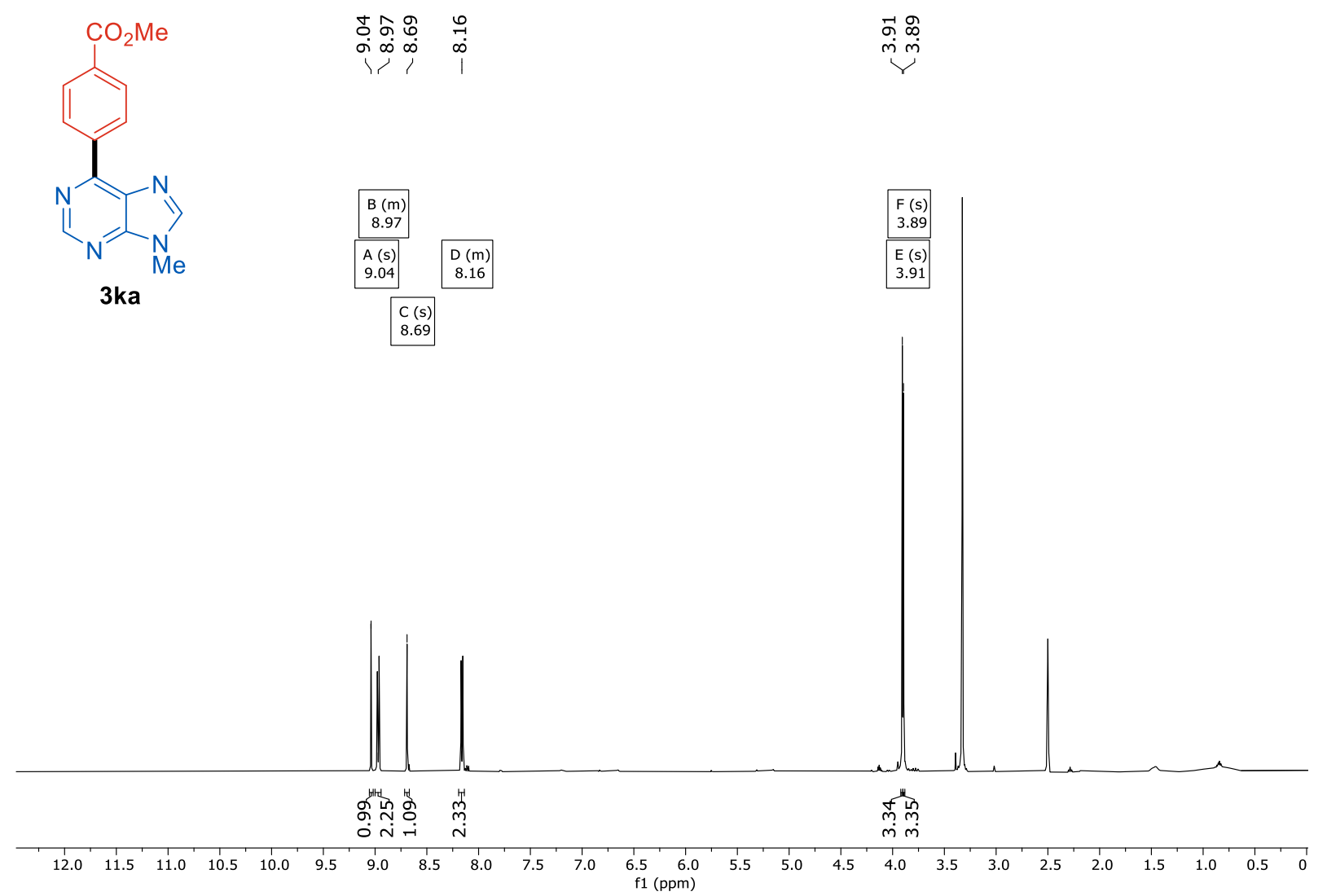

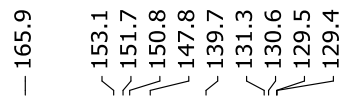
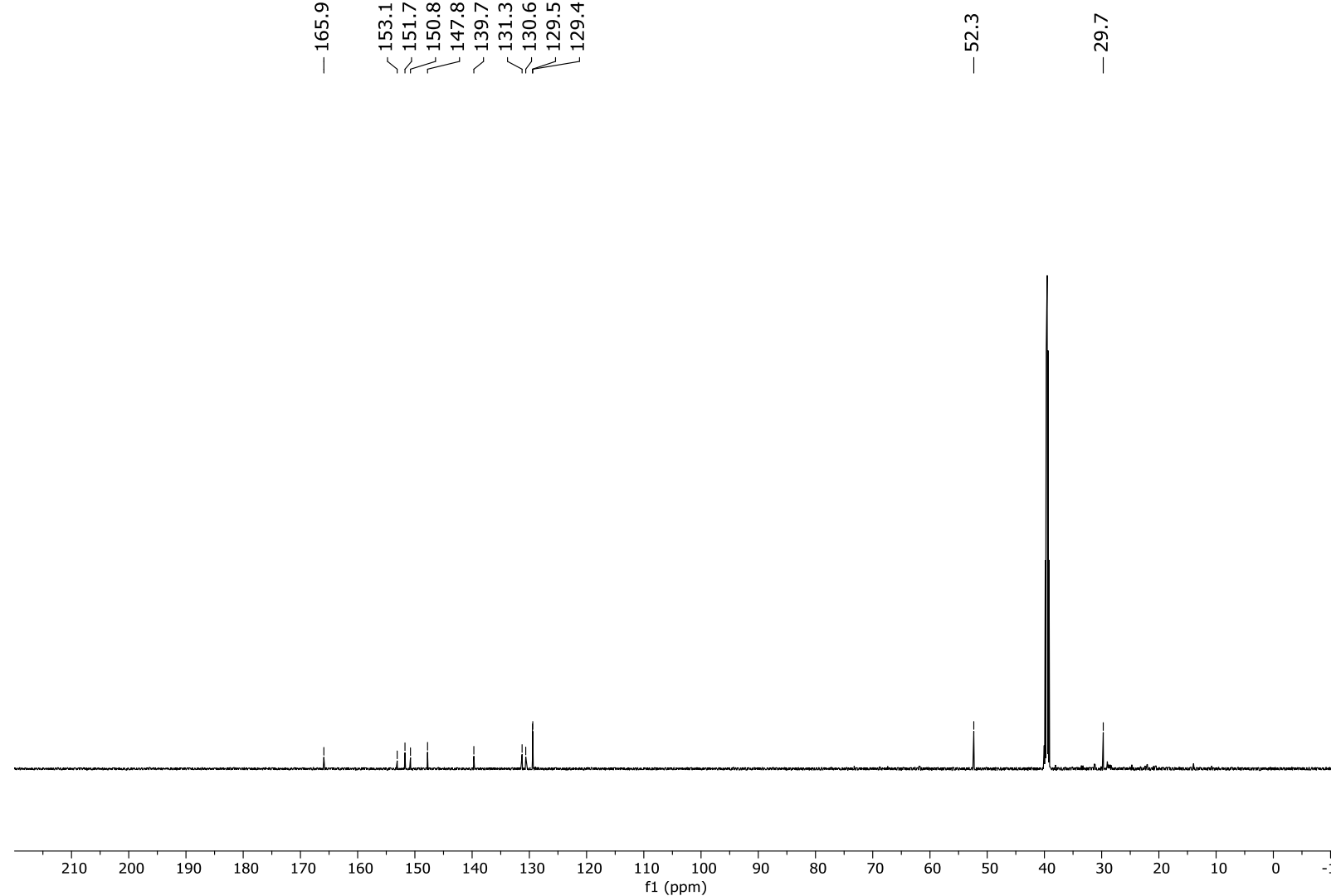


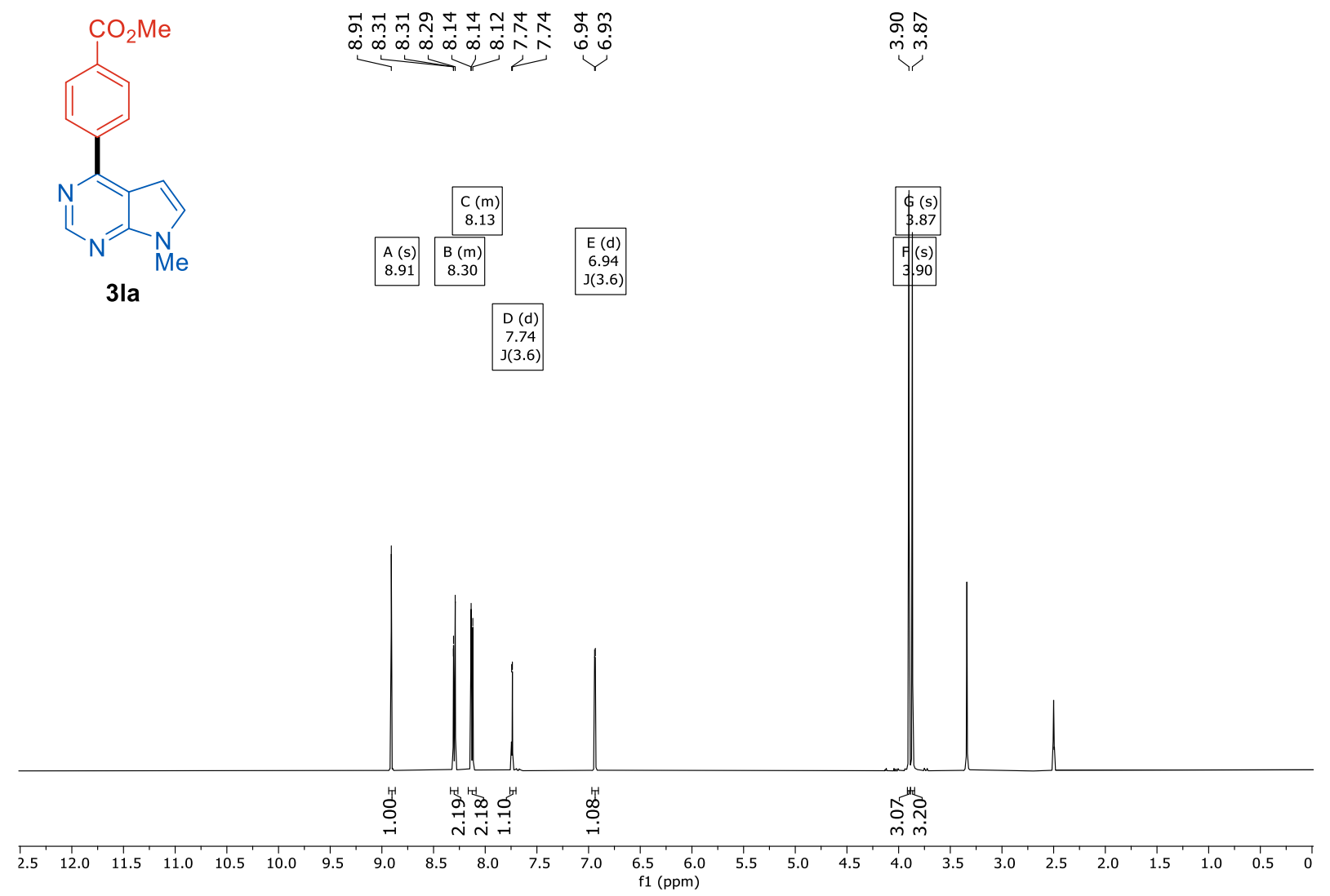

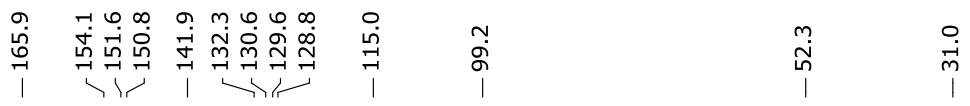

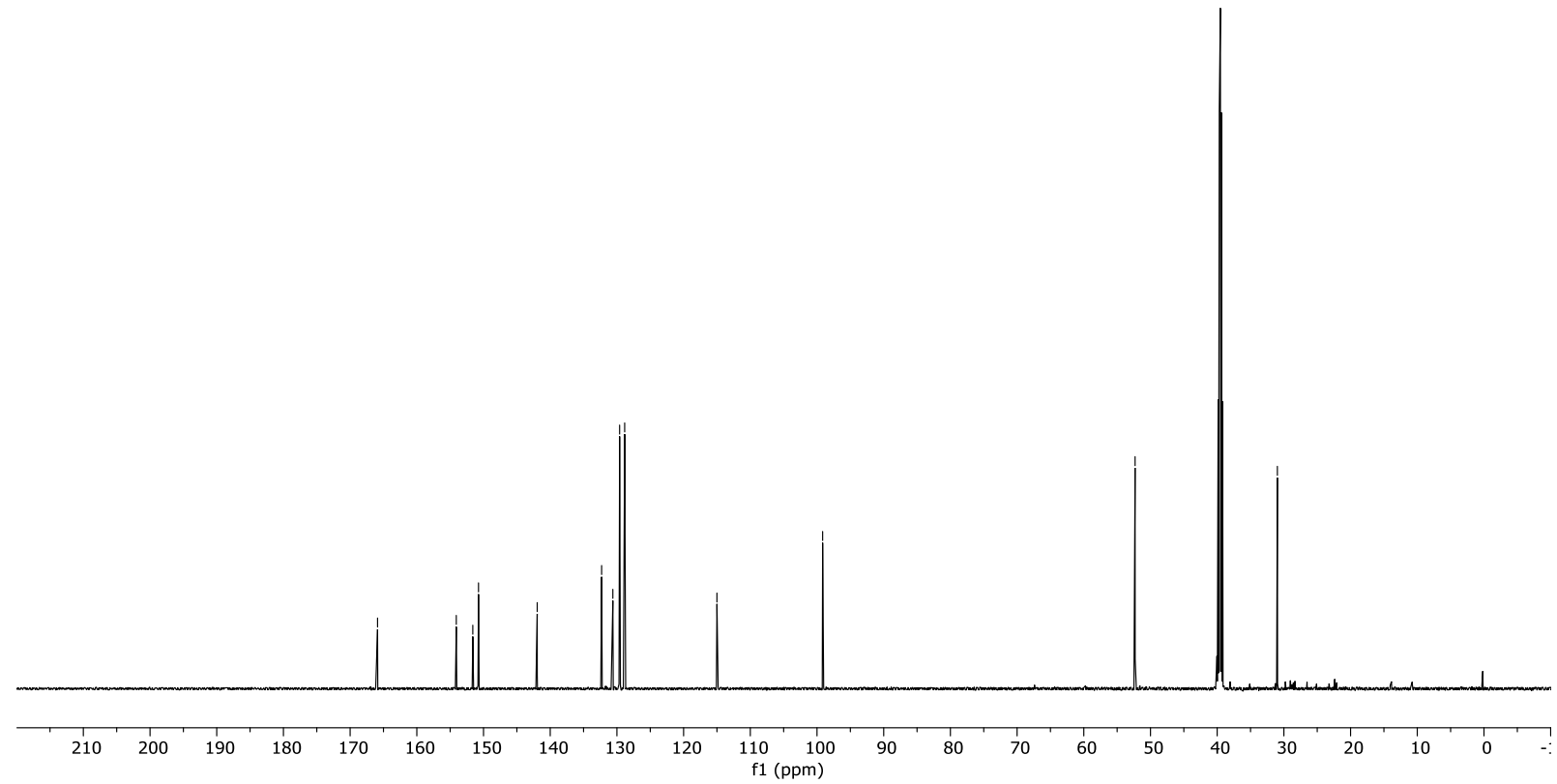



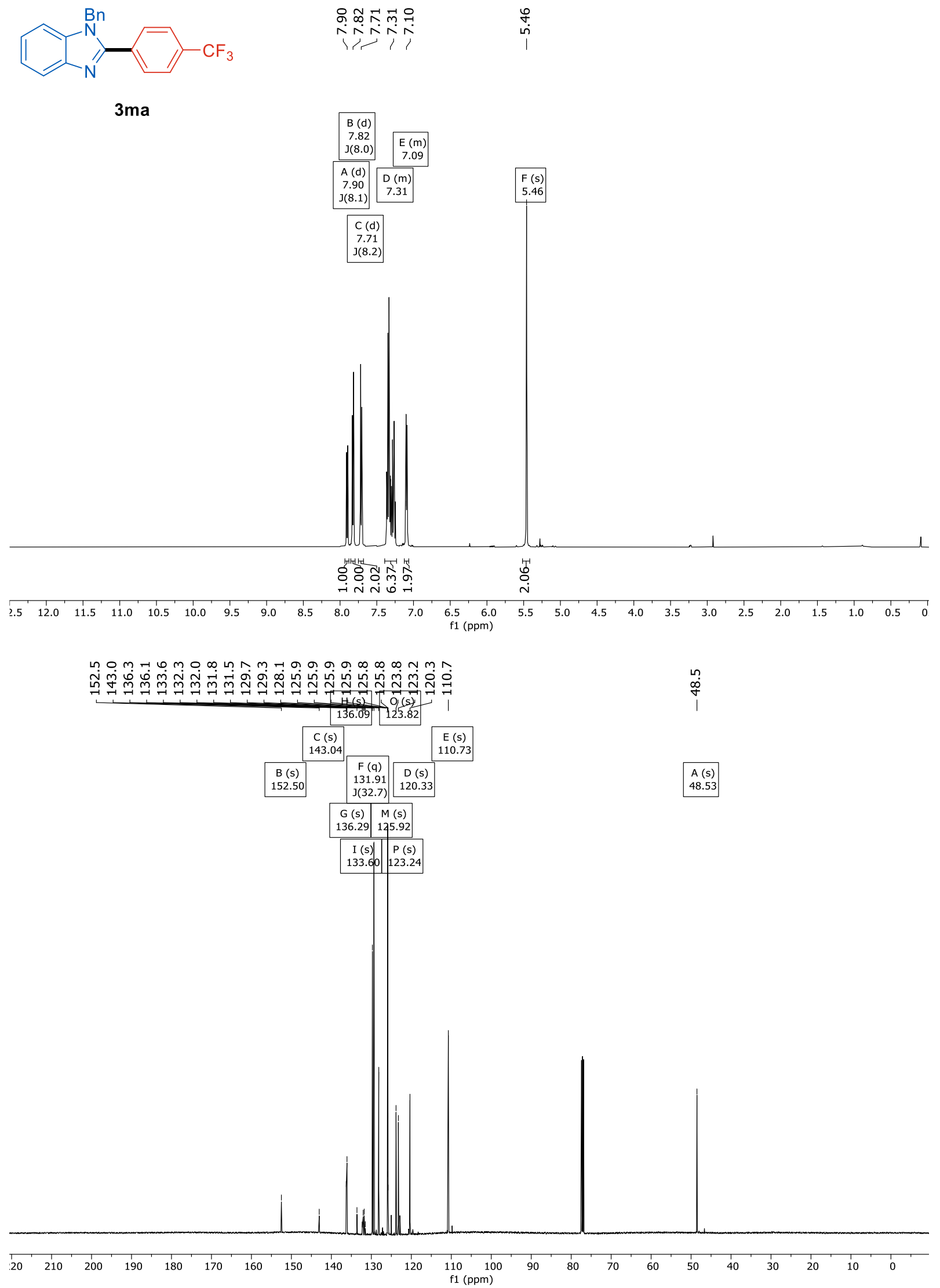
$\stackrel{\infty}{i}$

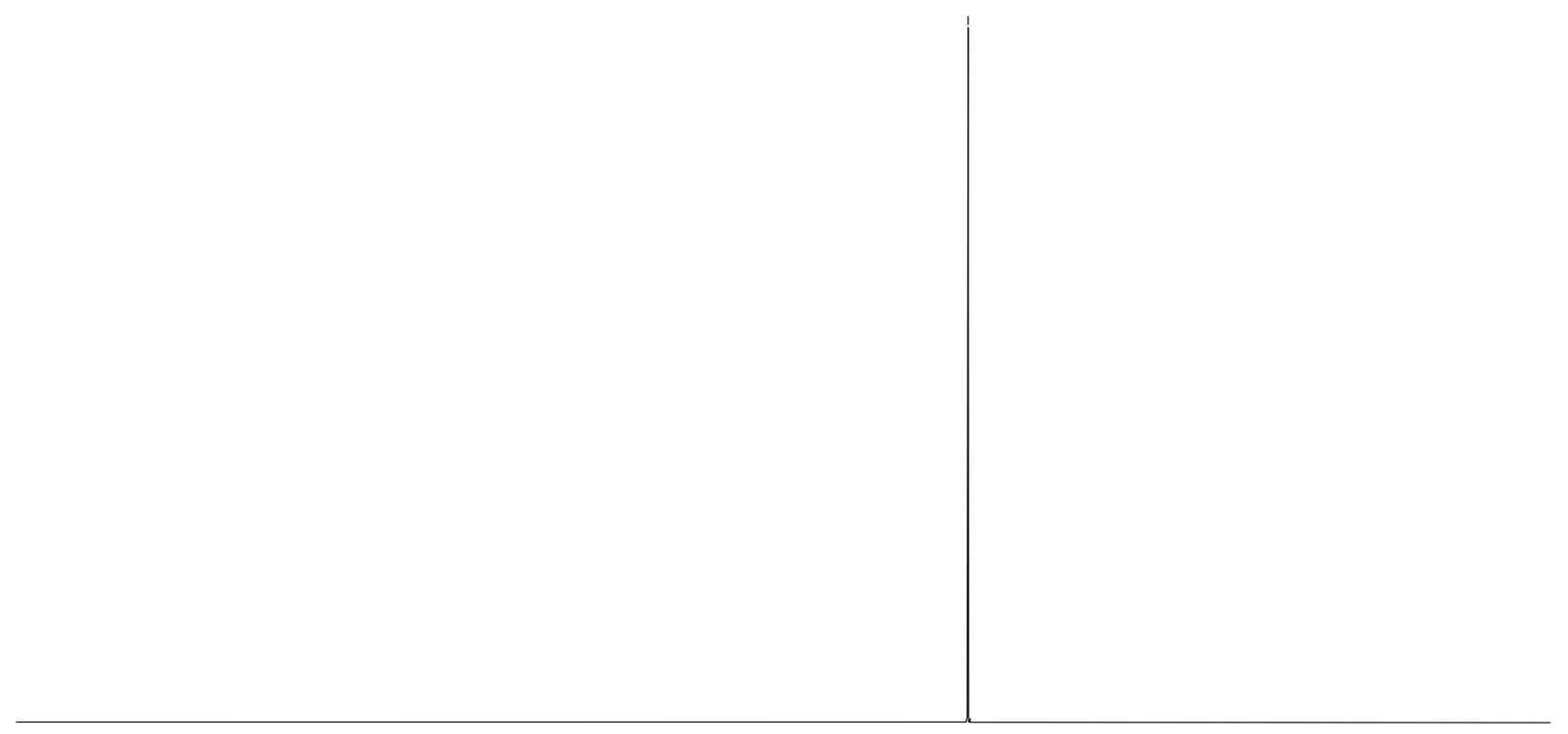

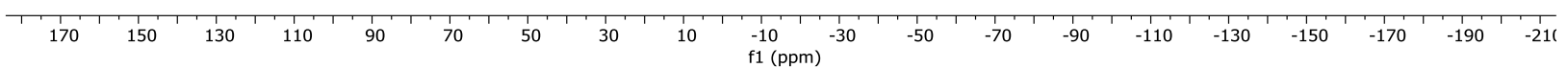



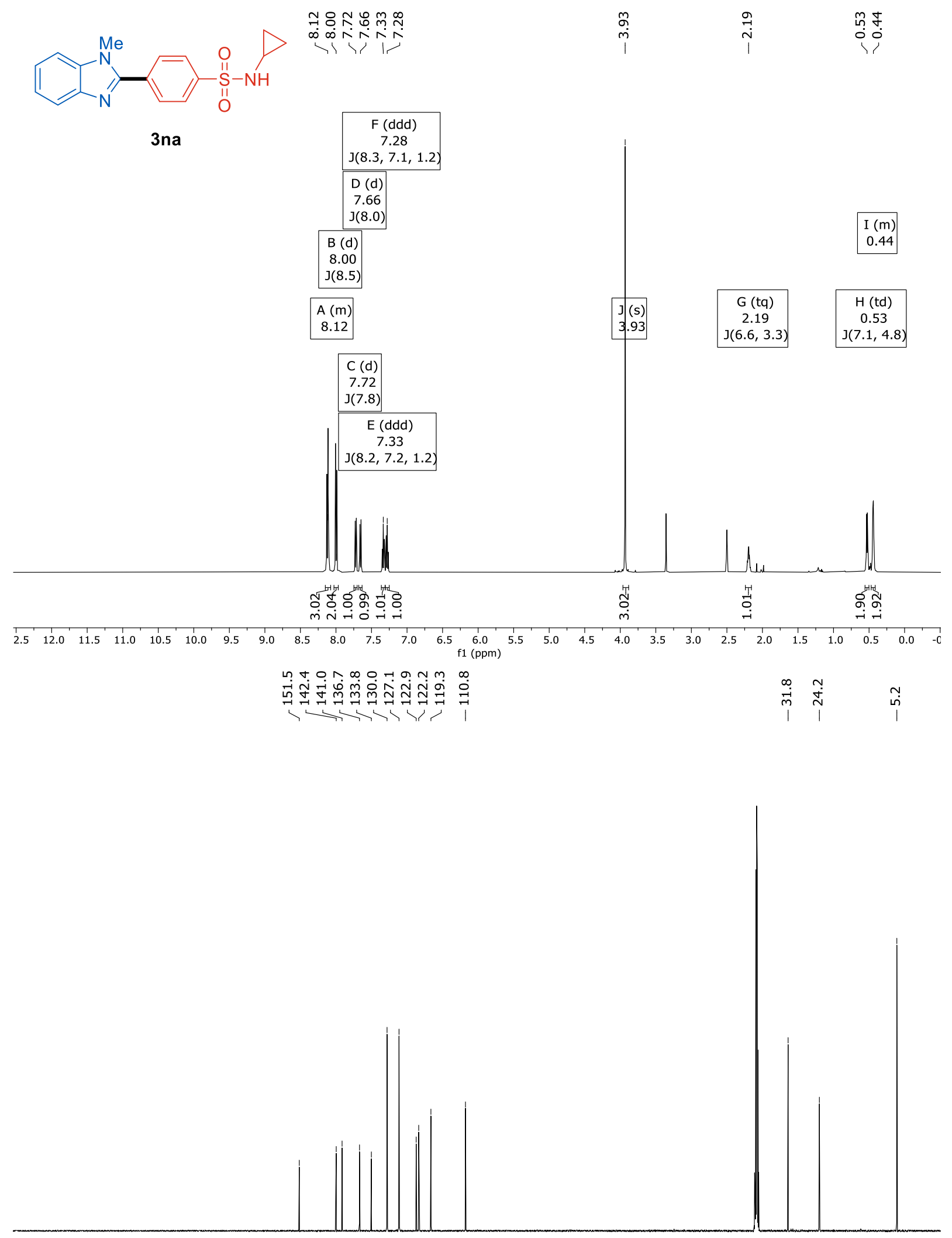


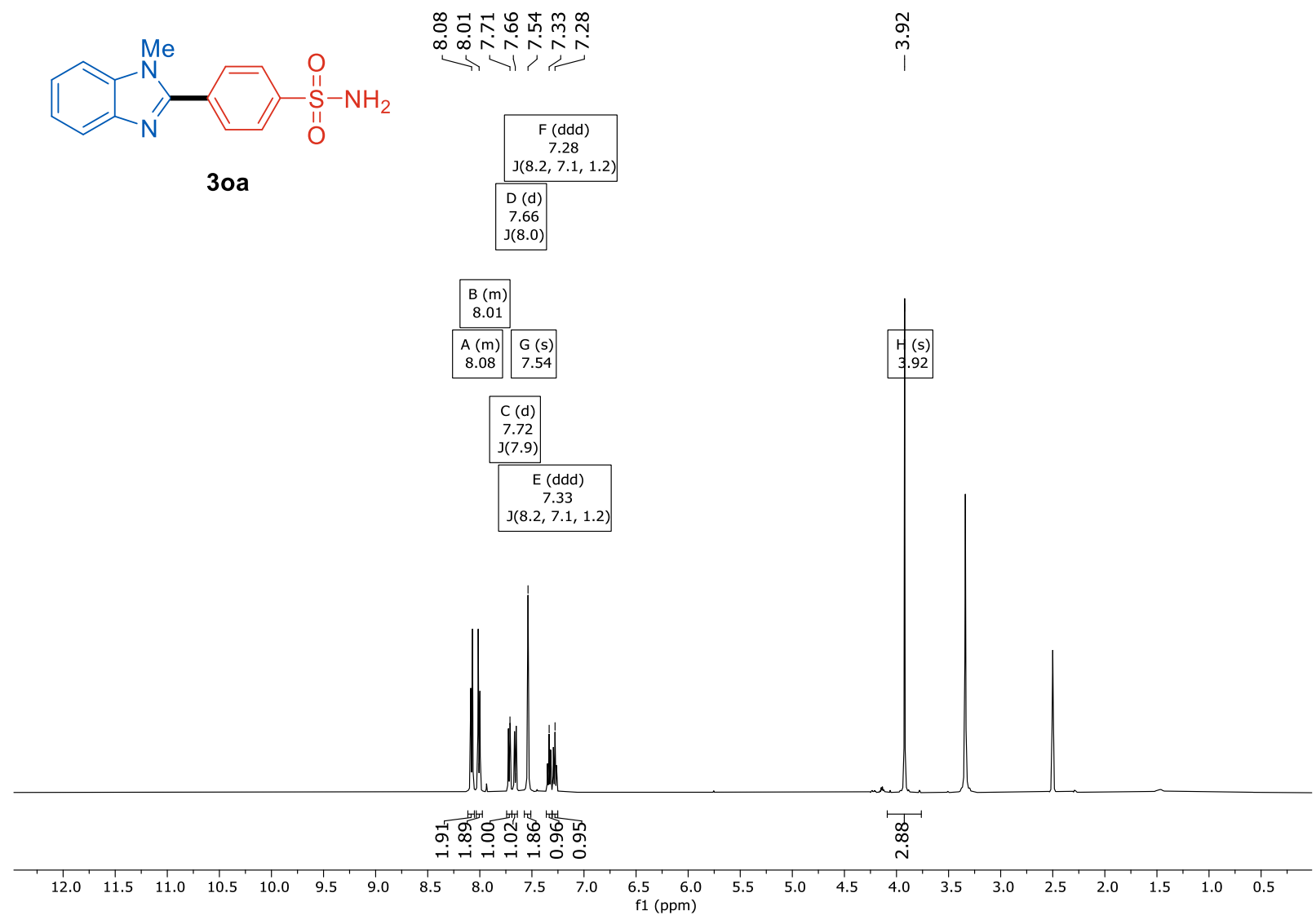

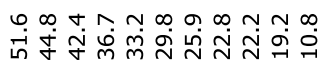

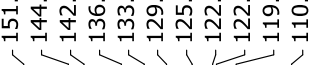

$\stackrel{\infty}{\dot{m}} \underset{1}{1}$

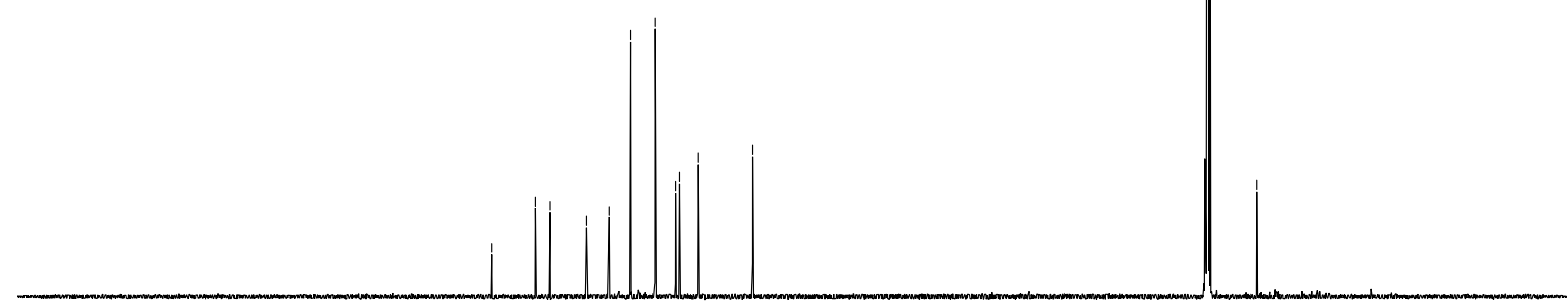

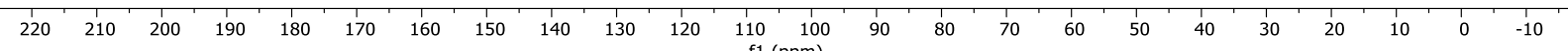



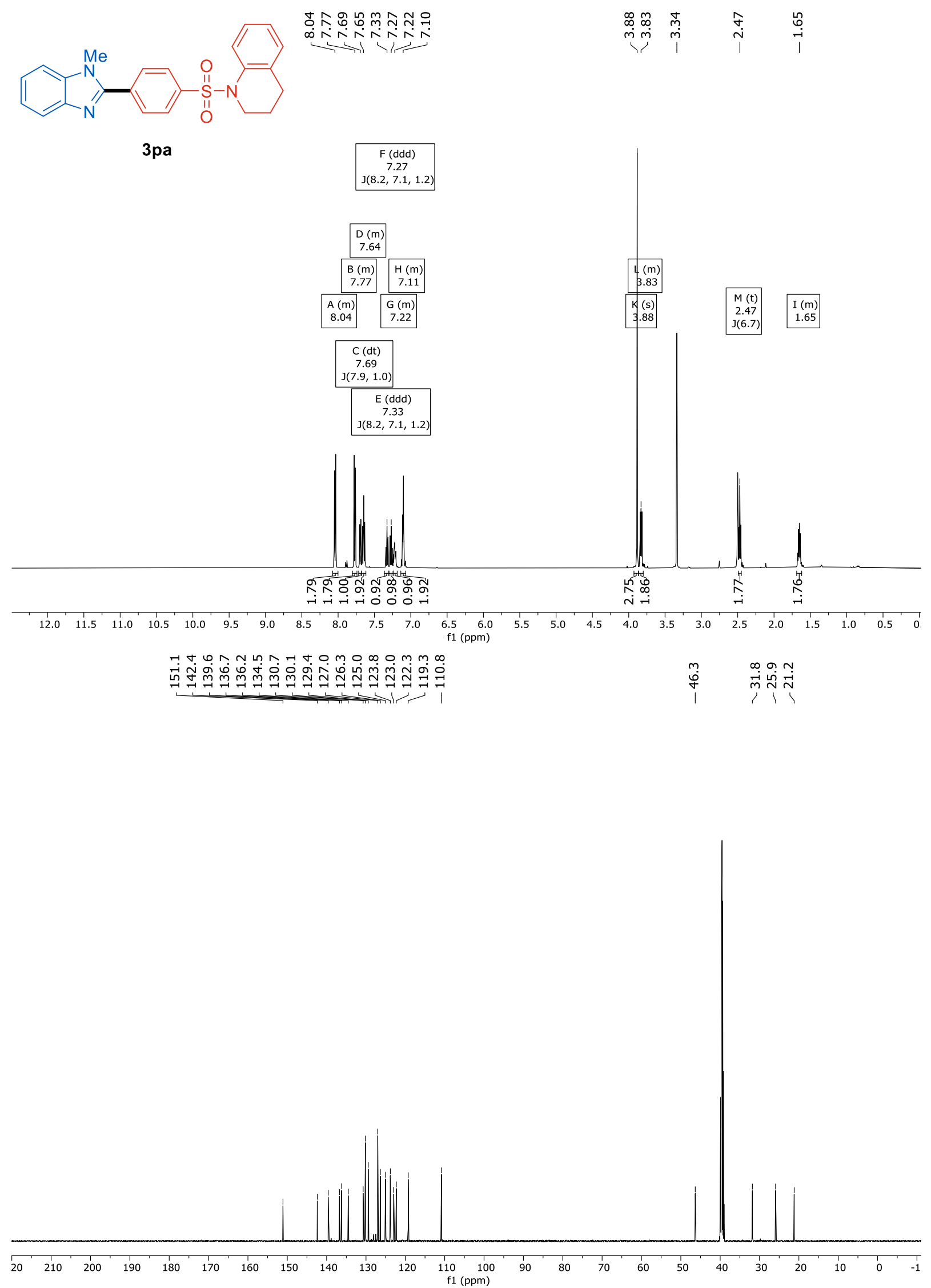

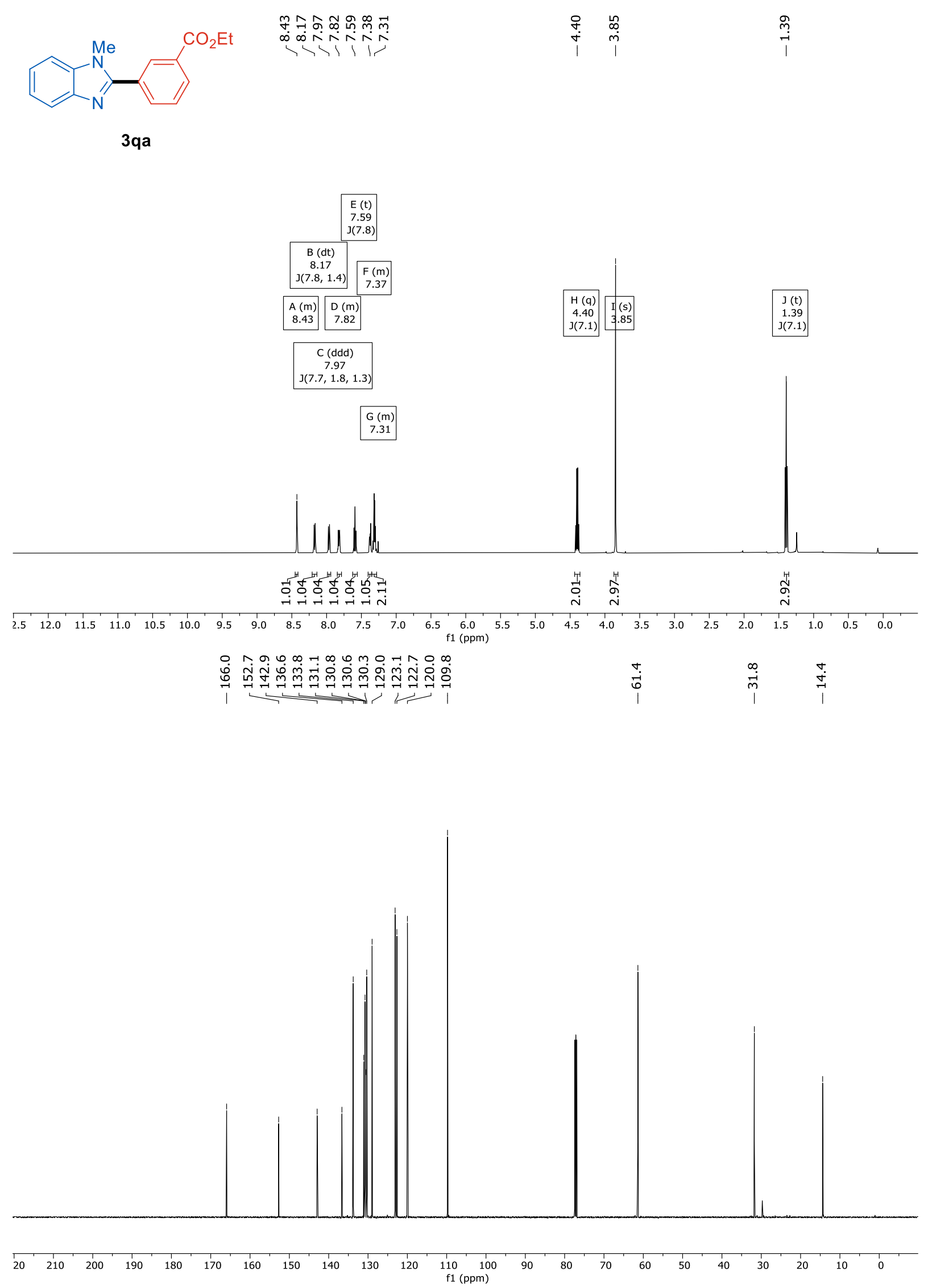

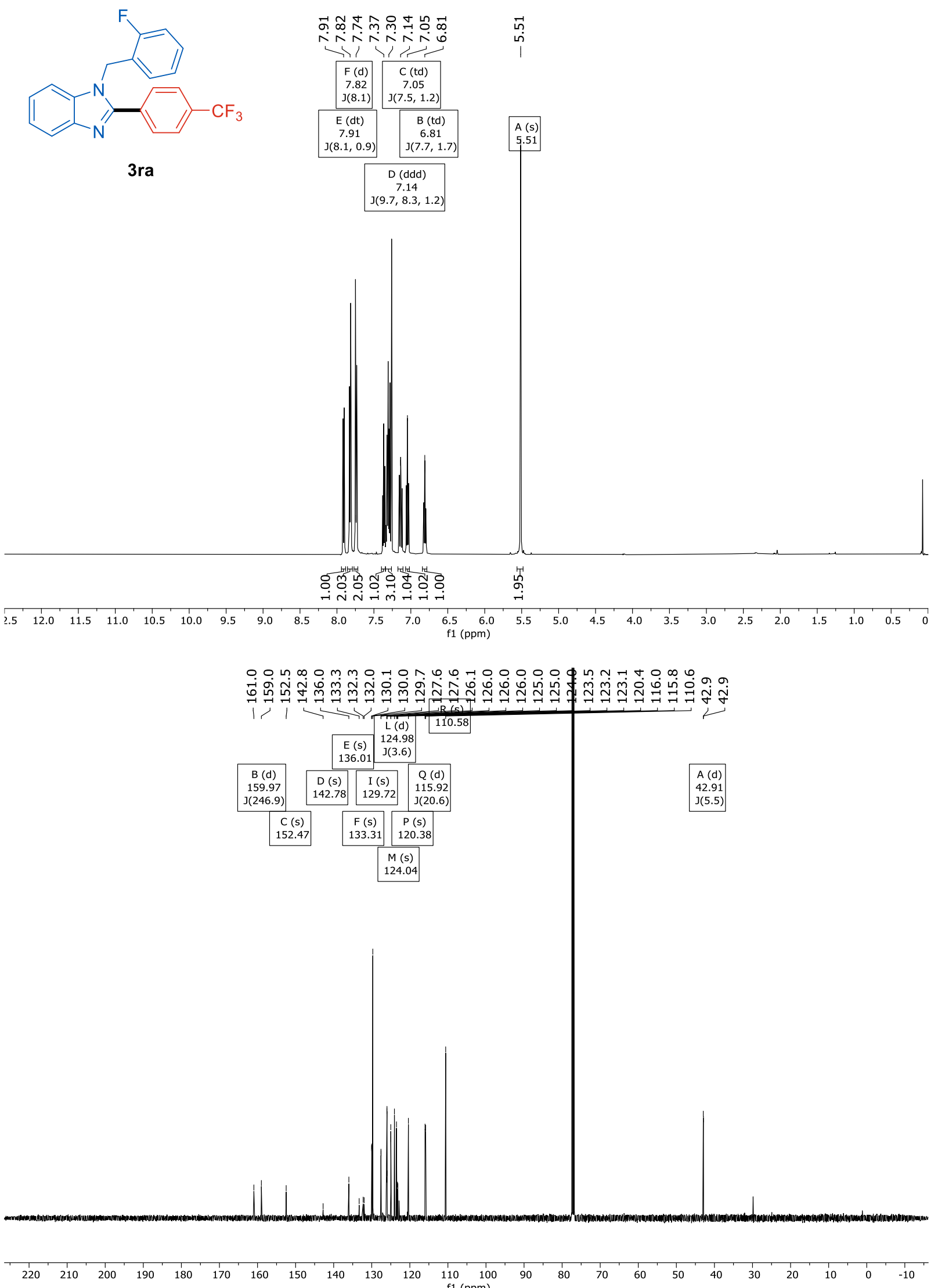
$\stackrel{9}{\text { ஸ̦ }}$

$\stackrel{\hat{\jmath}}{\hat{7}}$

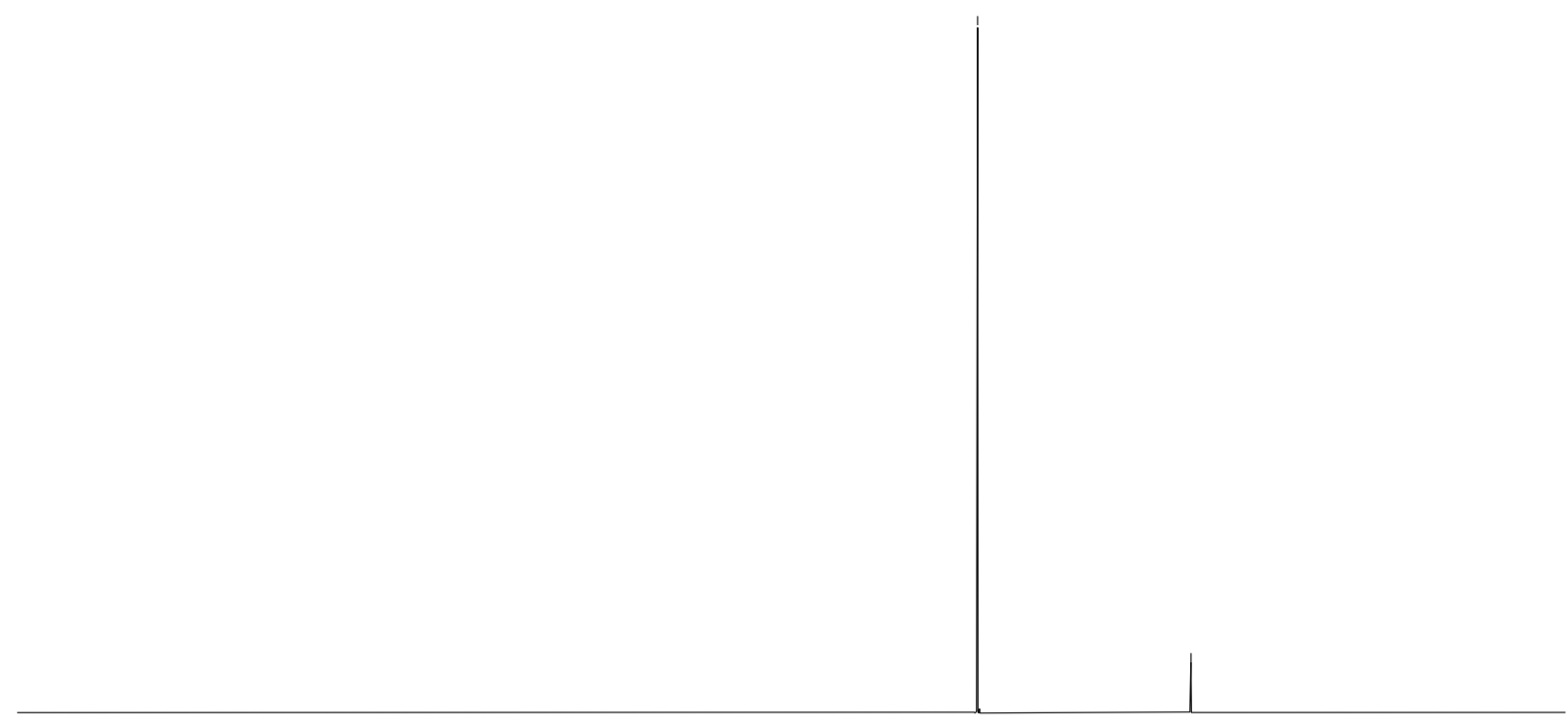

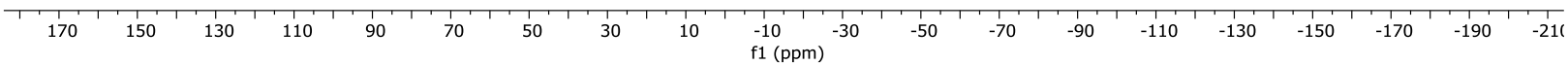



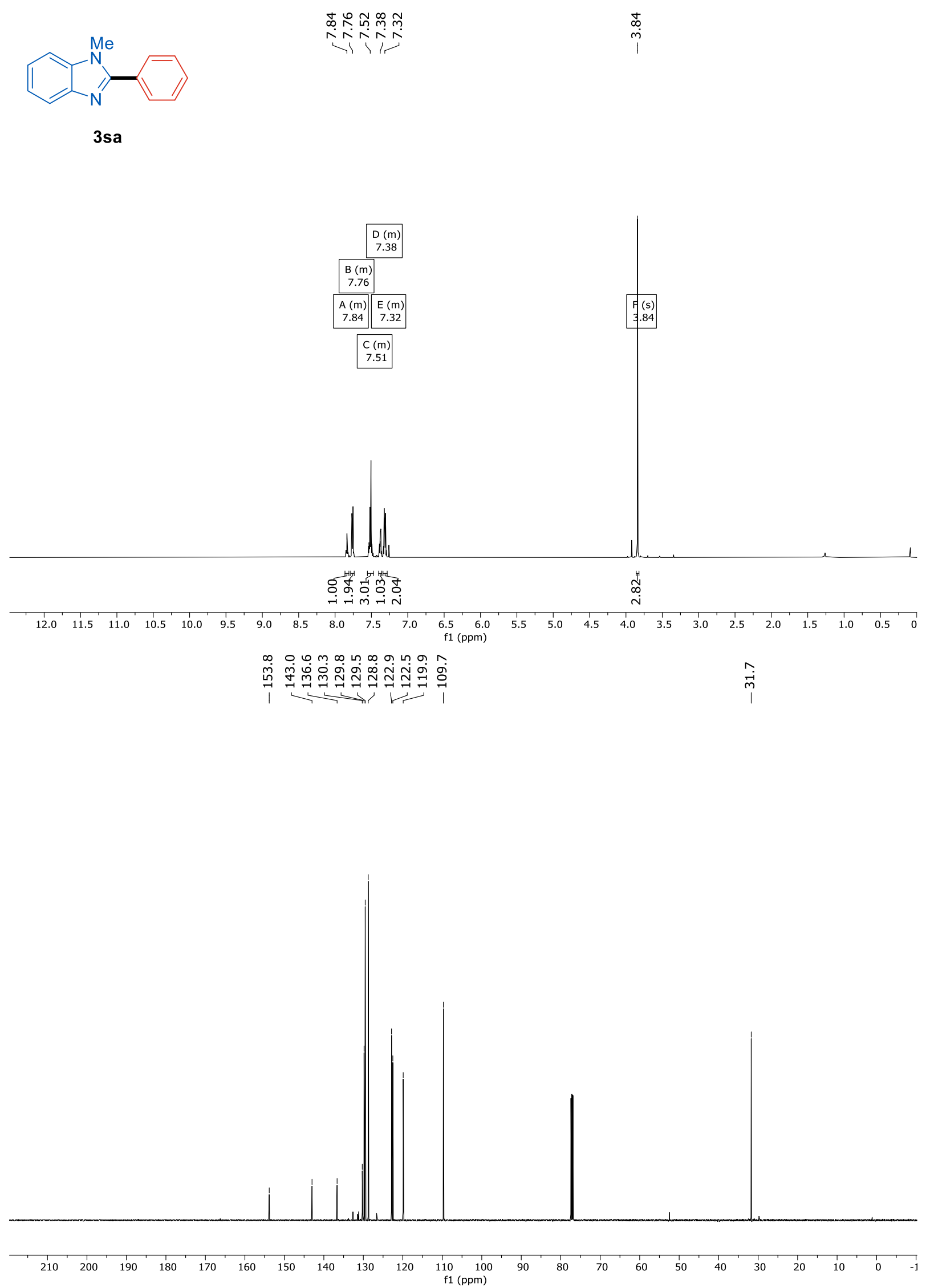


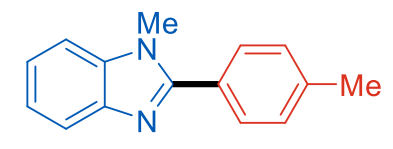

3ta
市욲

र̃

B (m)

$\begin{array}{r}B(\mathrm{~m}) \\ 7.40 \\ \hline\end{array}$

\begin{tabular}{|c|c|}
\hline$A(m)$ & $C(m)$ \\
\hline 7.84 & 7.33 \\
\hline
\end{tabular}

\begin{tabular}{ll|l|}
\hline 7.84 & 7.33 \\
\hline
\end{tabular}

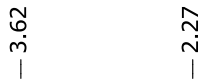

\begin{tabular}{|l|l|}
\hline$D(s)$ & $E(s)$ \\
3.62 & 2.27 \\
\hline
\end{tabular}

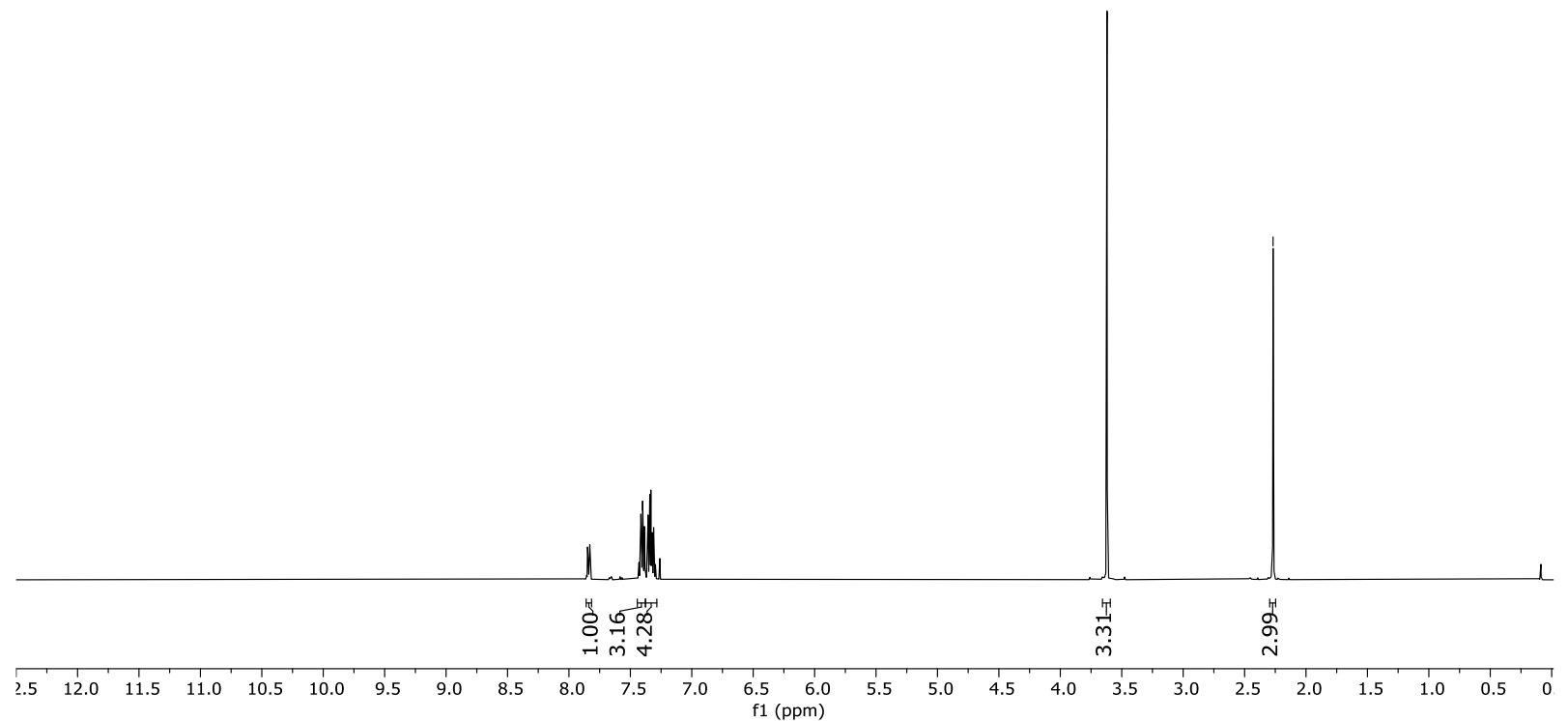

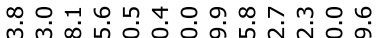

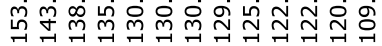

今े

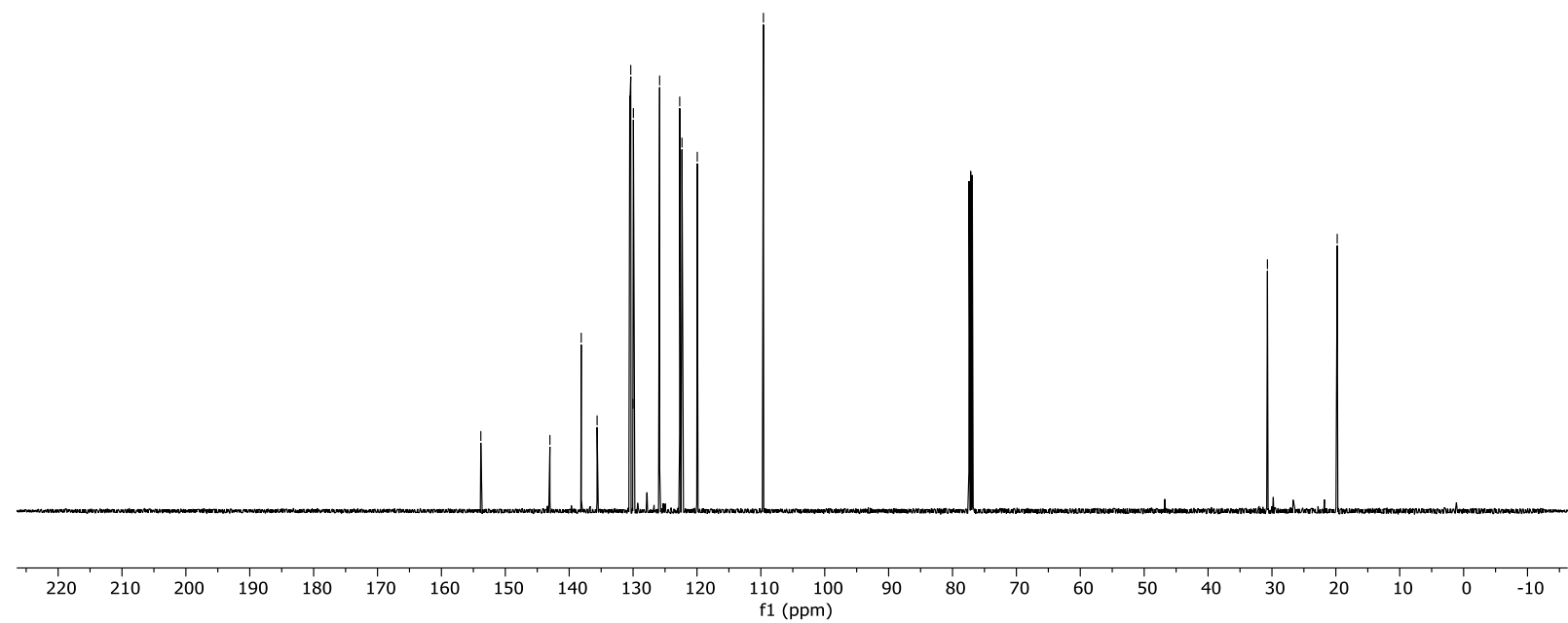




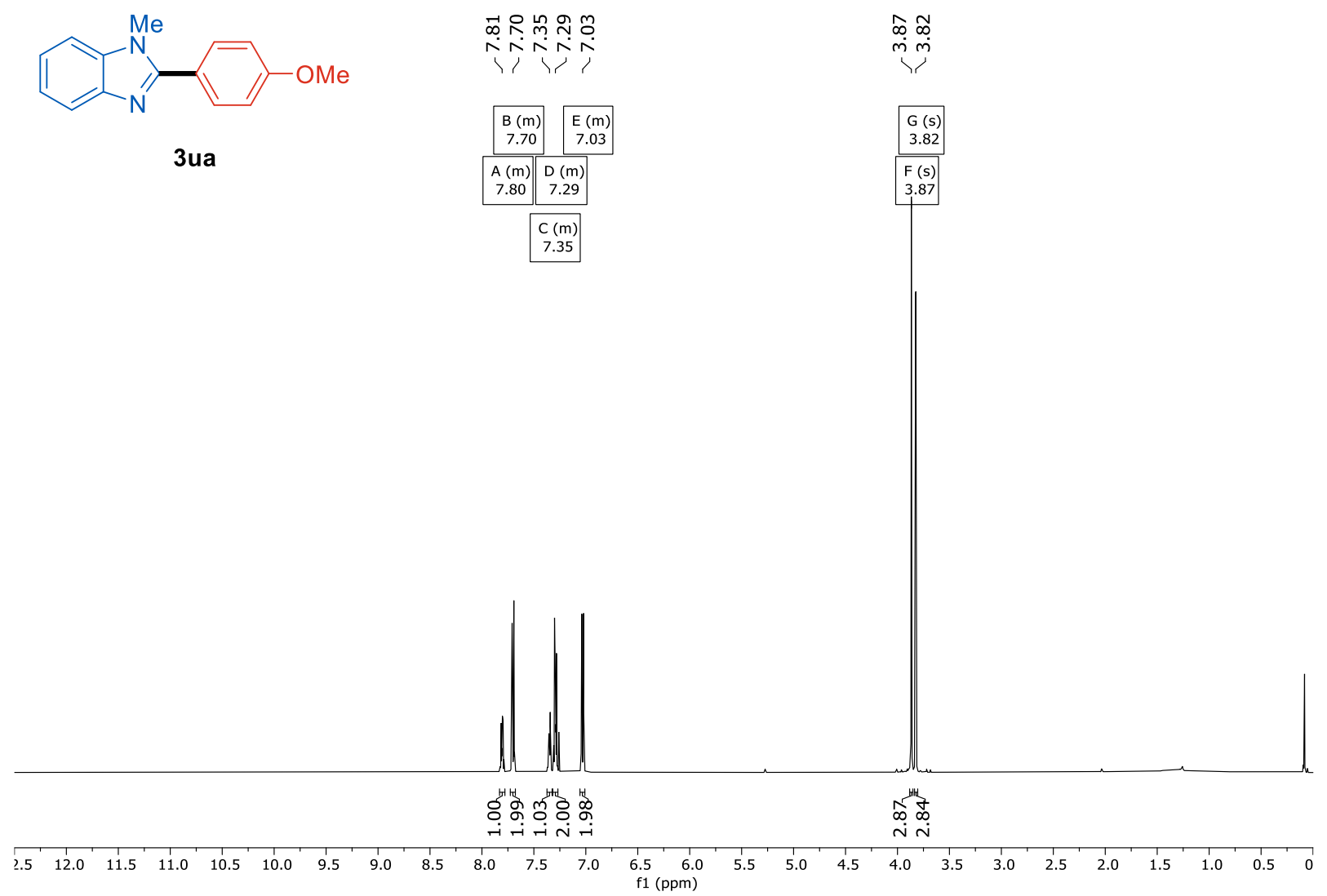

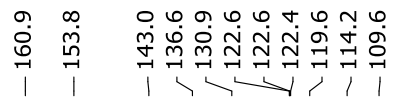

นn்

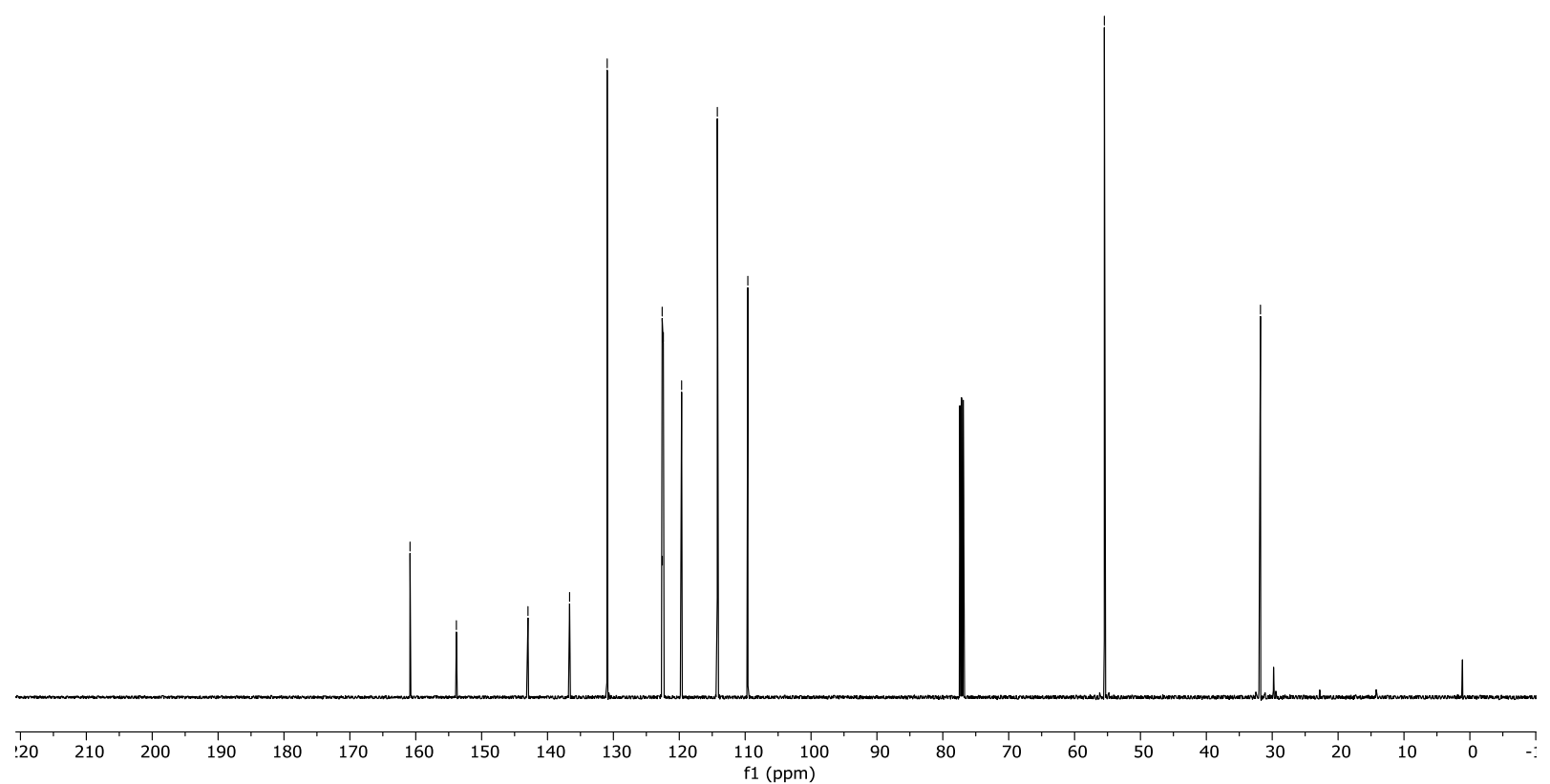




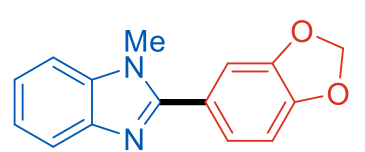

3va


तNNก
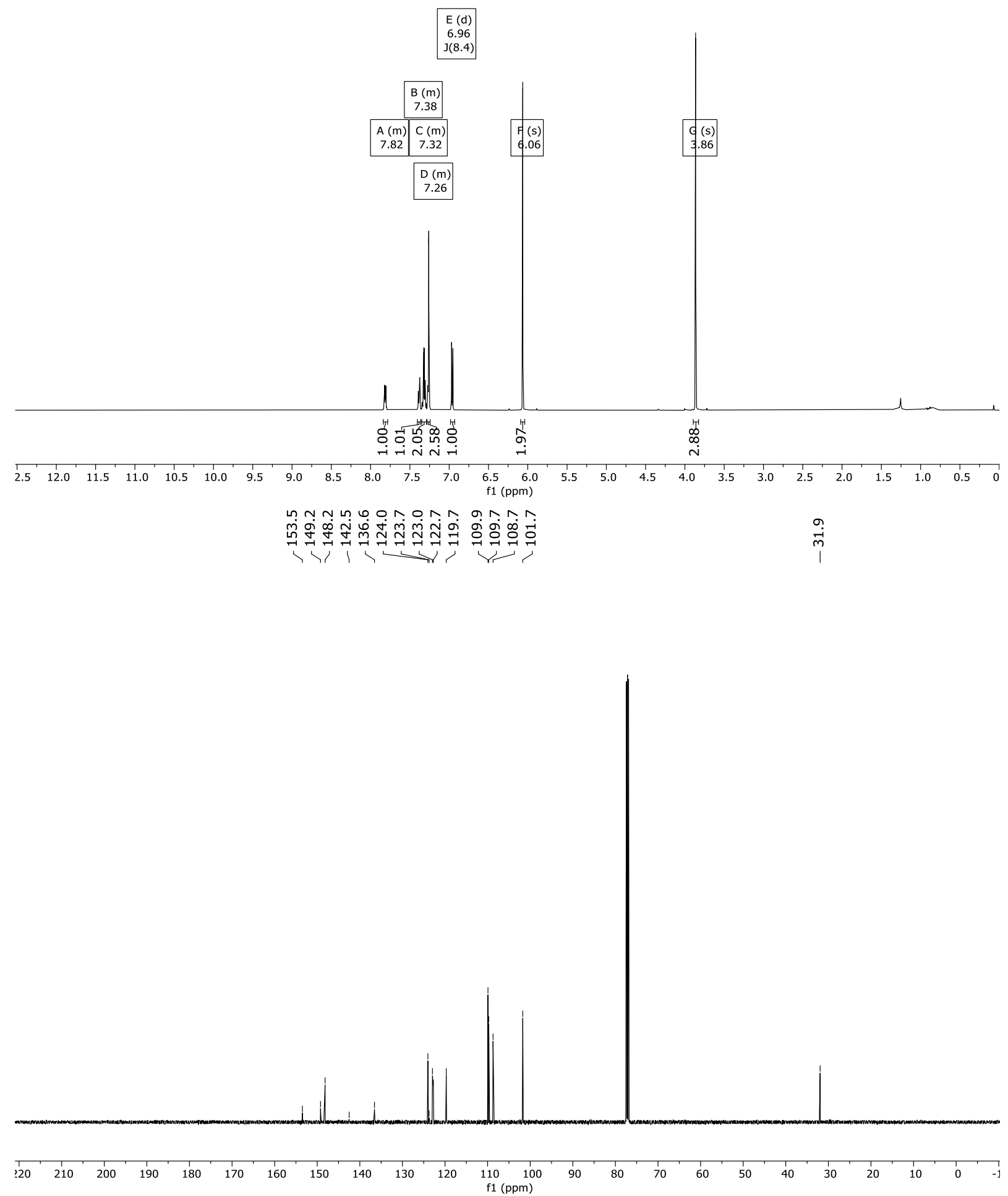


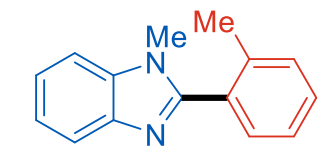

3wa
雍守

in

B (m)

$\begin{array}{r}B(\mathrm{~m}) \\ 7.40 \\ \hline\end{array}$

\begin{tabular}{|l|l|}
\hline$A(m)$ & $C(m)$ \\
7.84 & 7.33 \\
\hline
\end{tabular}

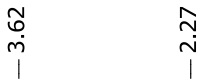

\begin{tabular}{|l|l|}
\hline$D(s)$ & $E(s)$ \\
\hline 3.62 & 2.27 \\
\hline
\end{tabular}

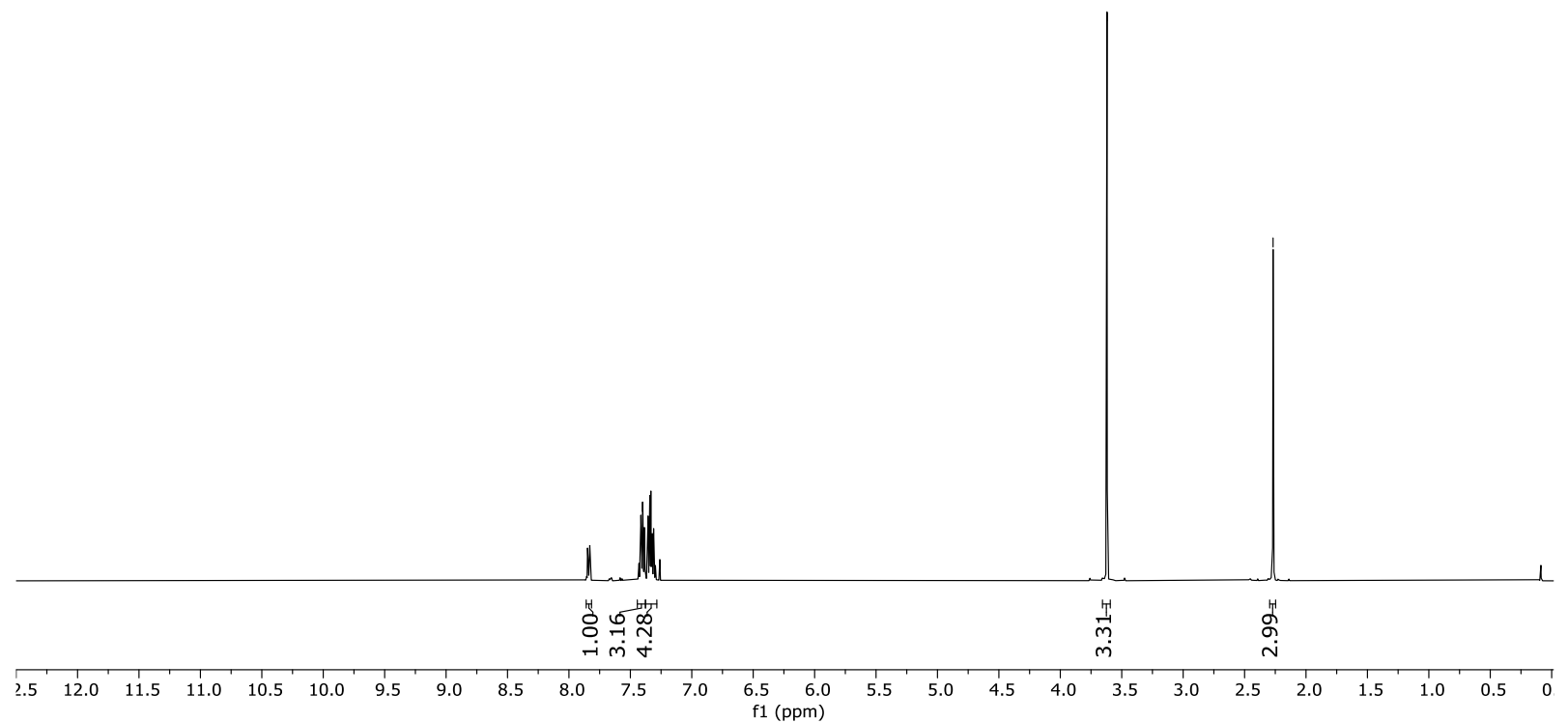

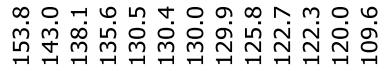

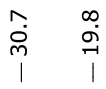

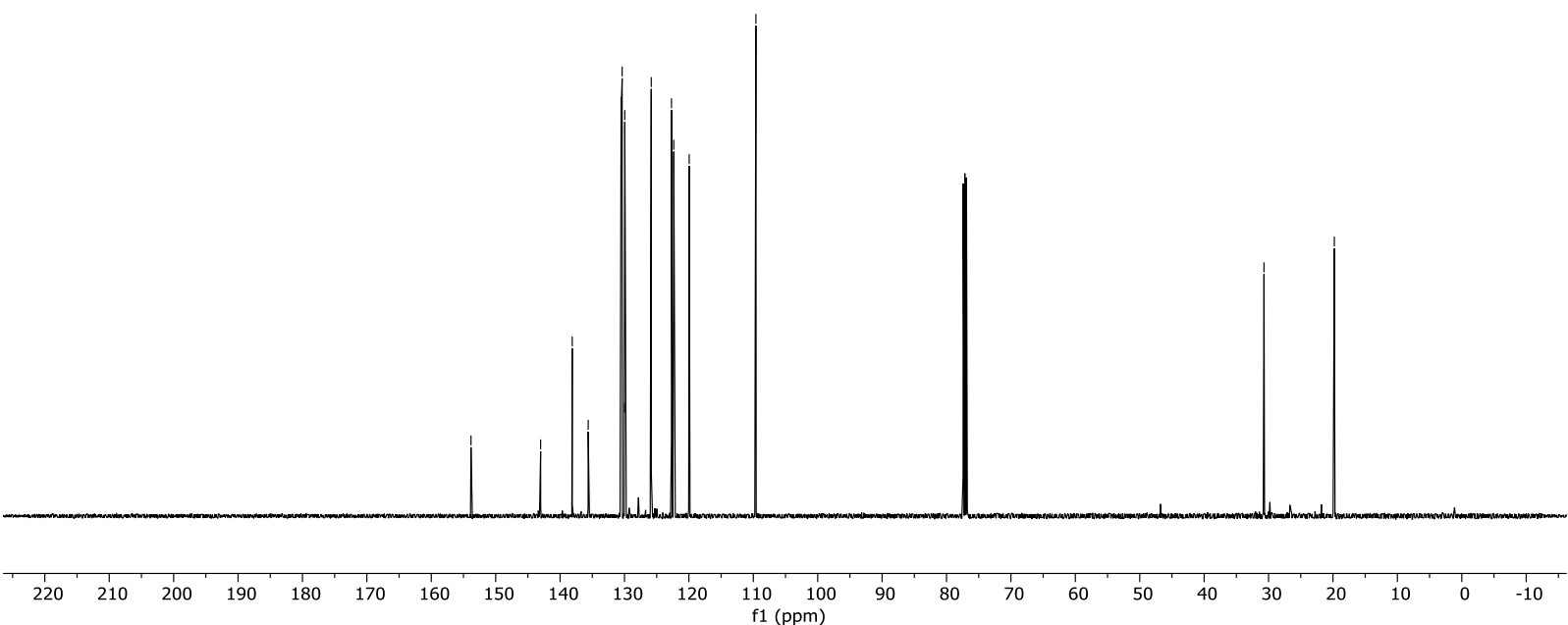



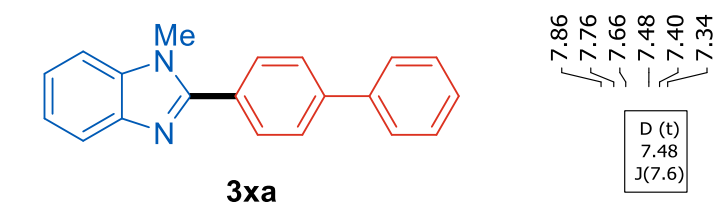

$\infty$
$\infty$
m
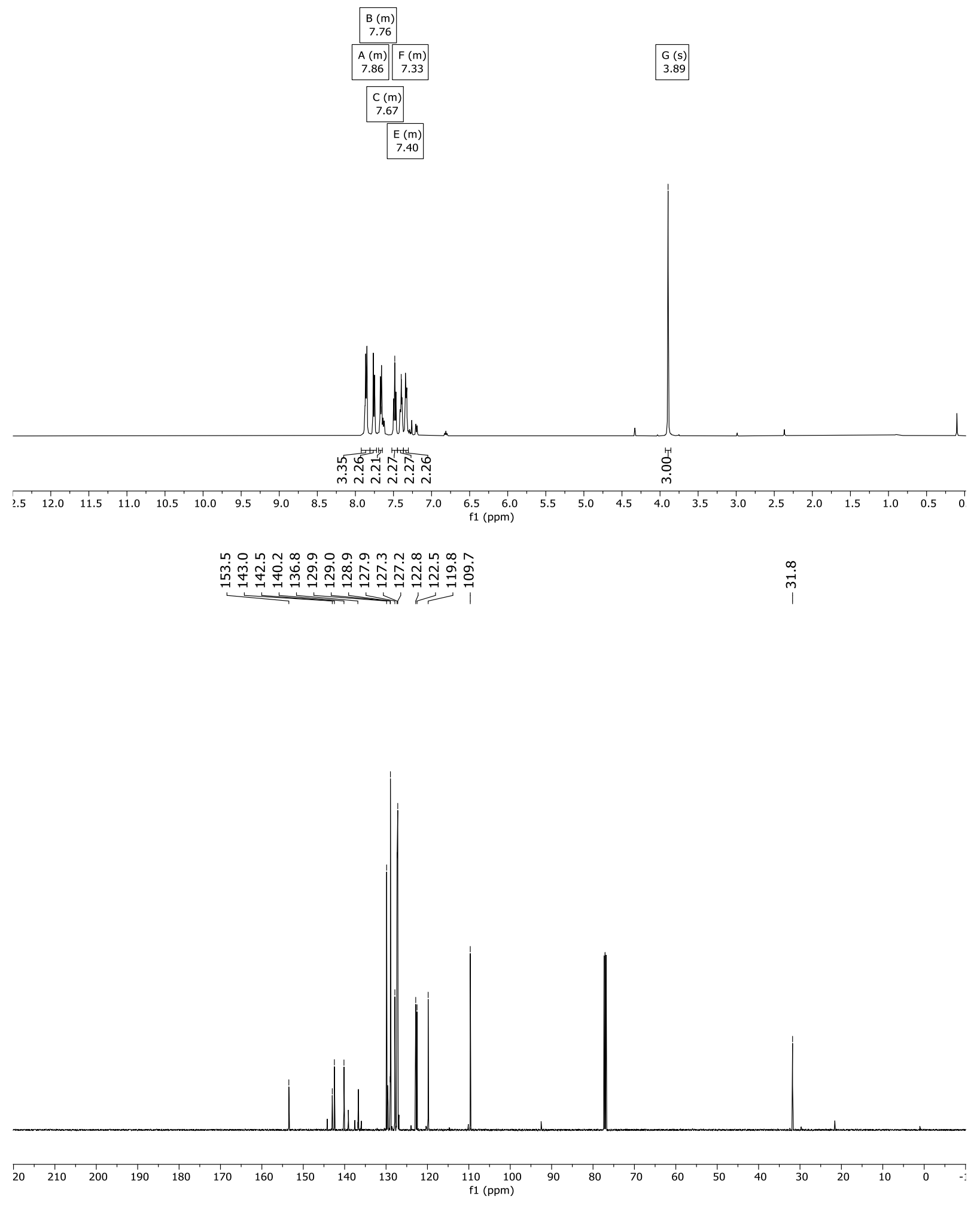


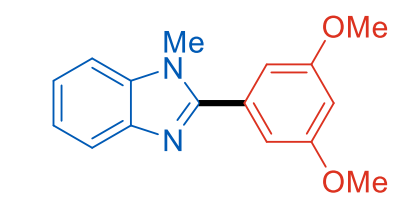

$3 \times a$
Nㅜำ

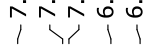

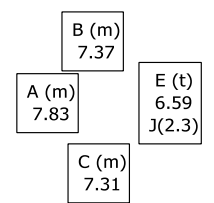

$\stackrel{+}{\infty}$

$\mathrm{F}(\mathrm{s})$

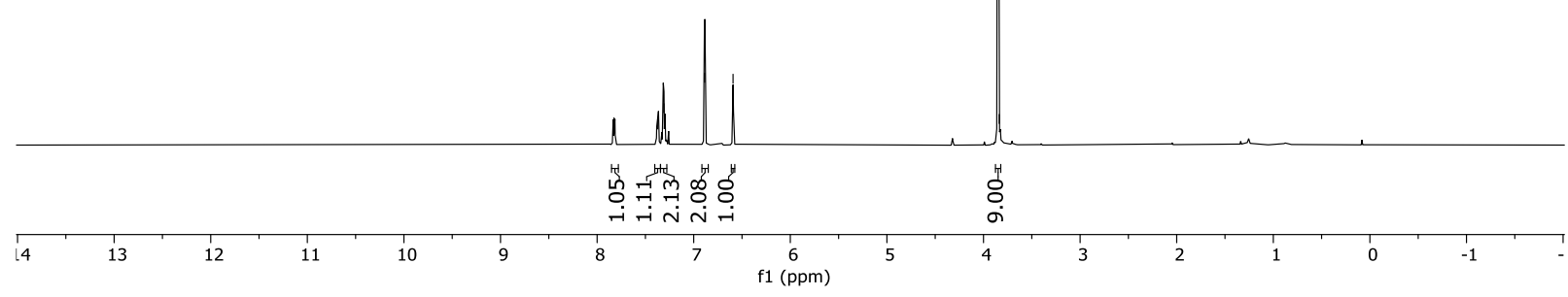

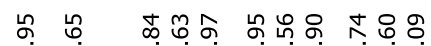

نำ

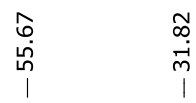

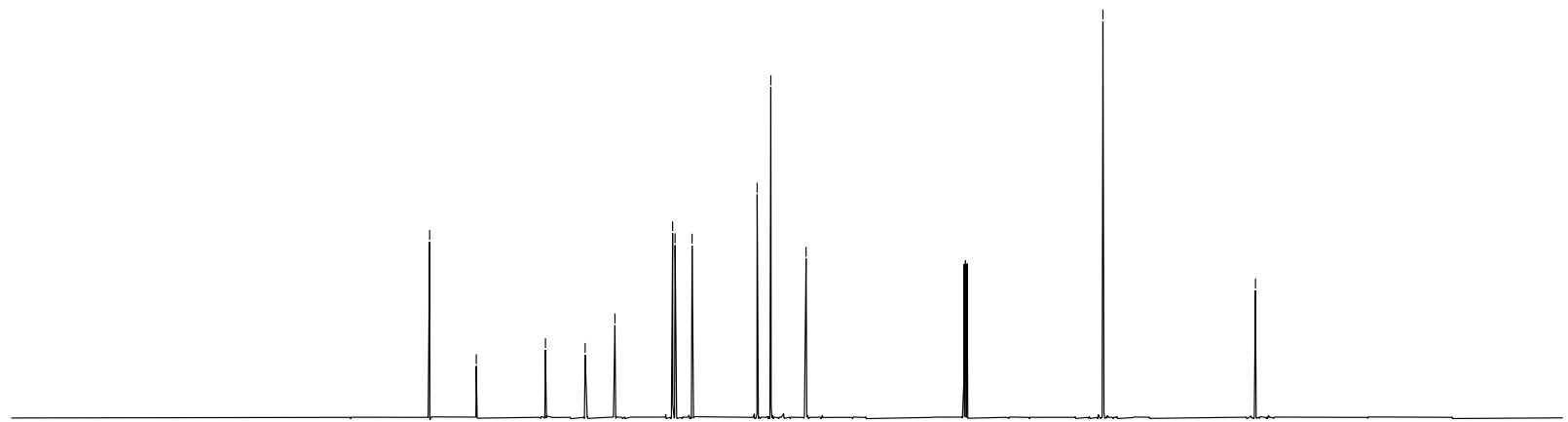




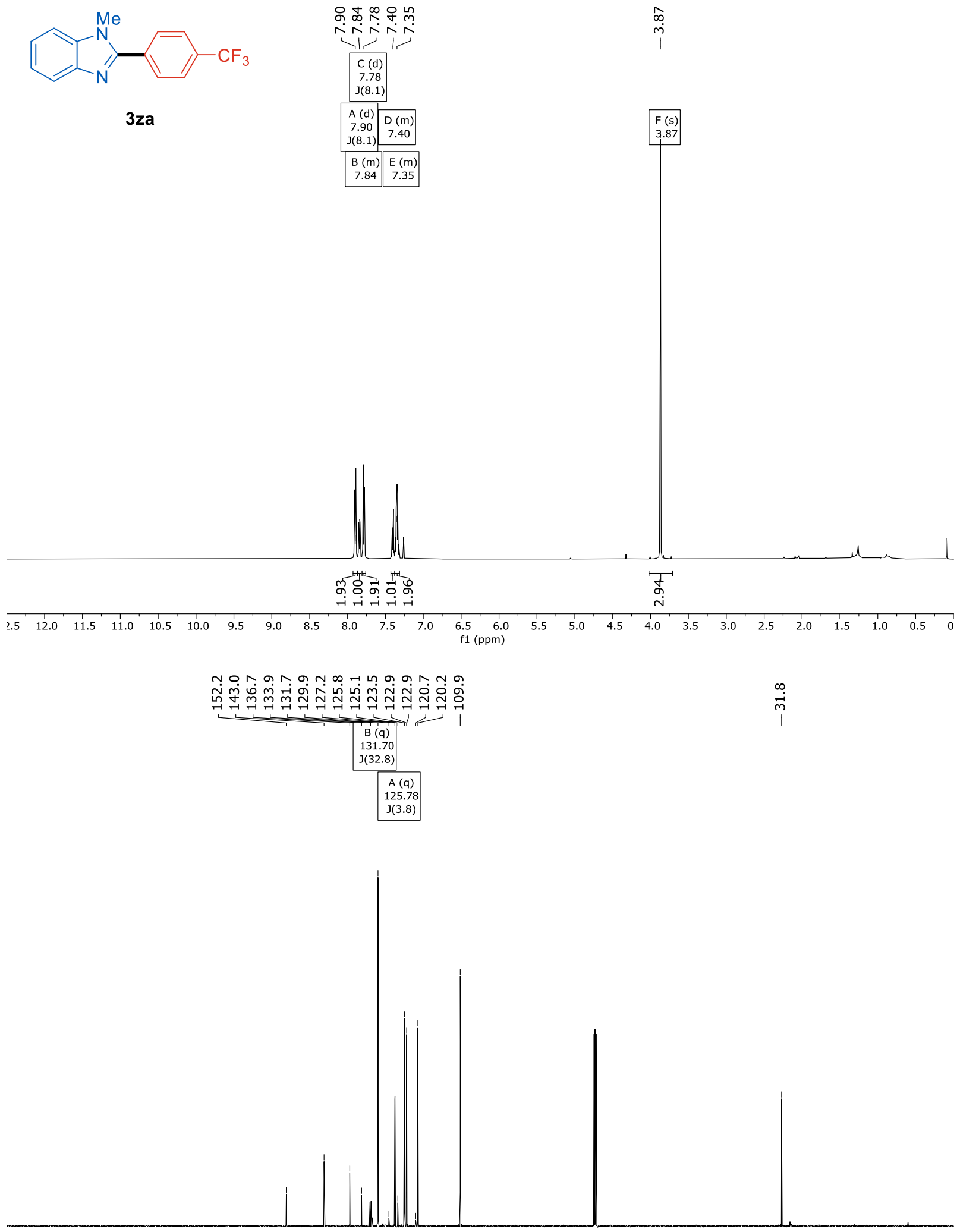

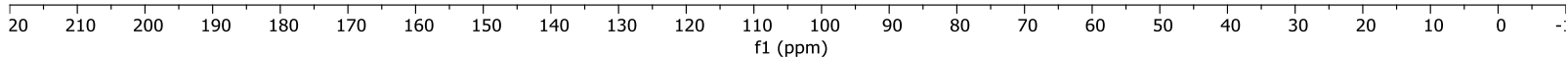




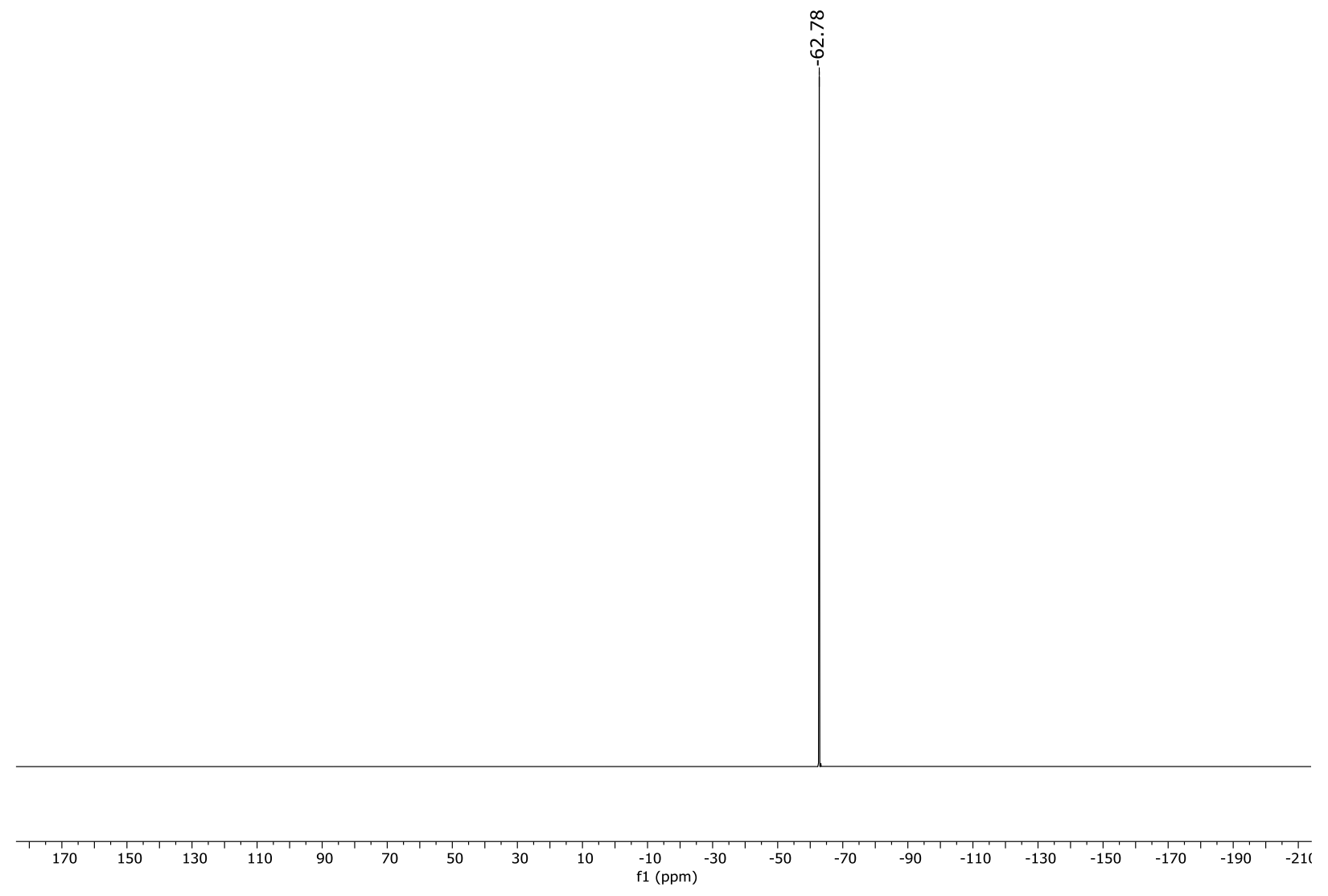




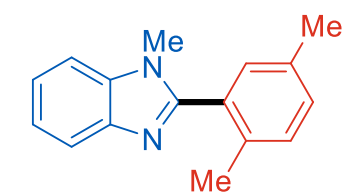

$3 a b$

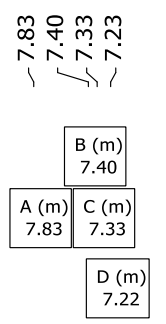

$\stackrel{\substack{n \\ i}}{i}$

E (s)

3.63

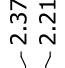
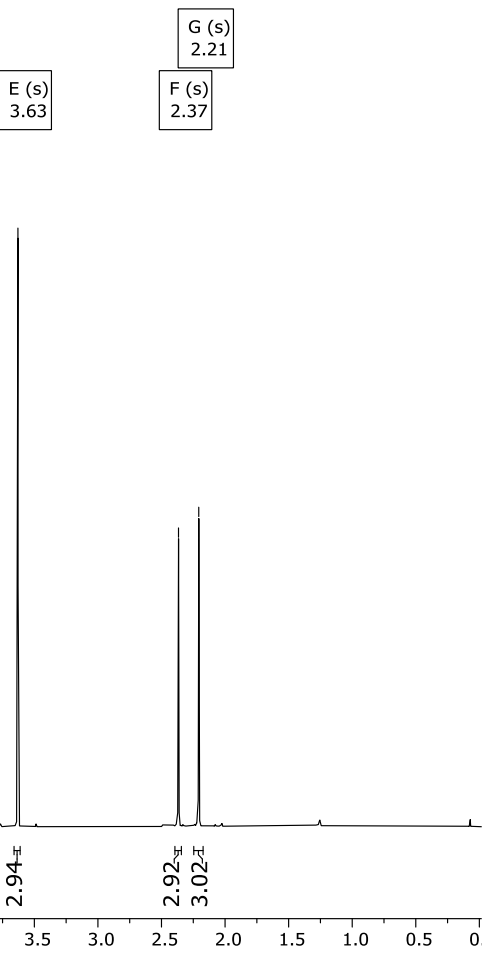

พิน

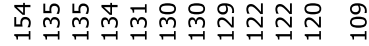

난

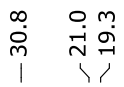

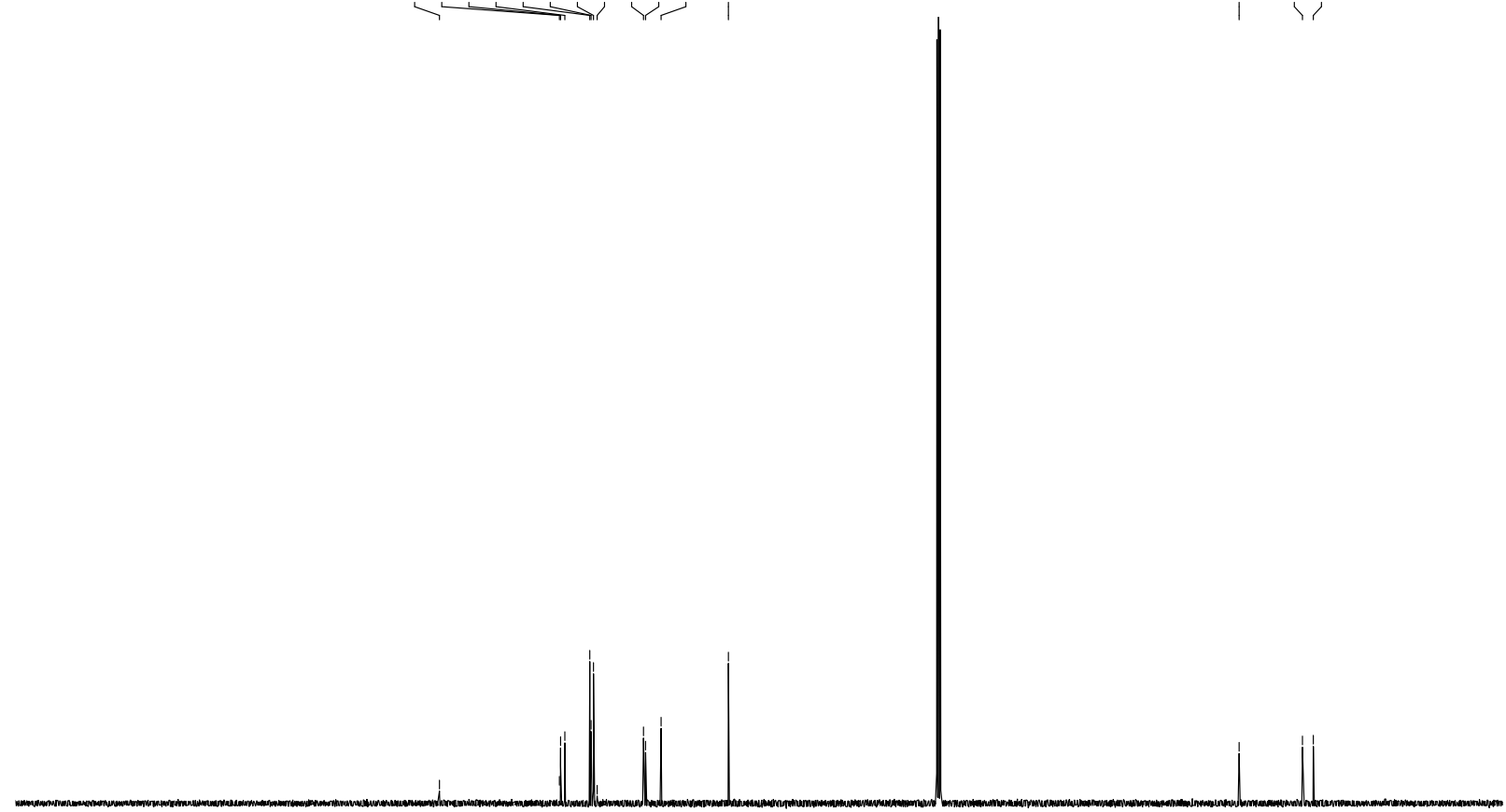

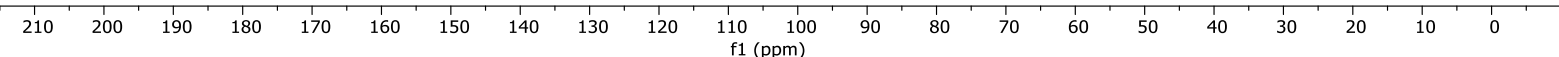




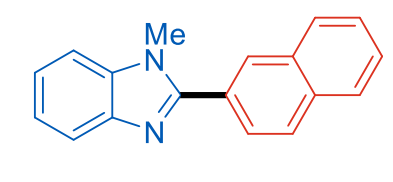

$3 b b$

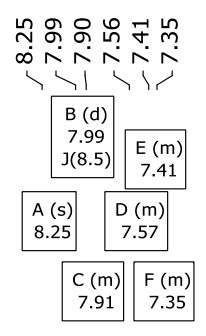

$\stackrel{\sim}{\text { ๙ุ }}$

G (s)

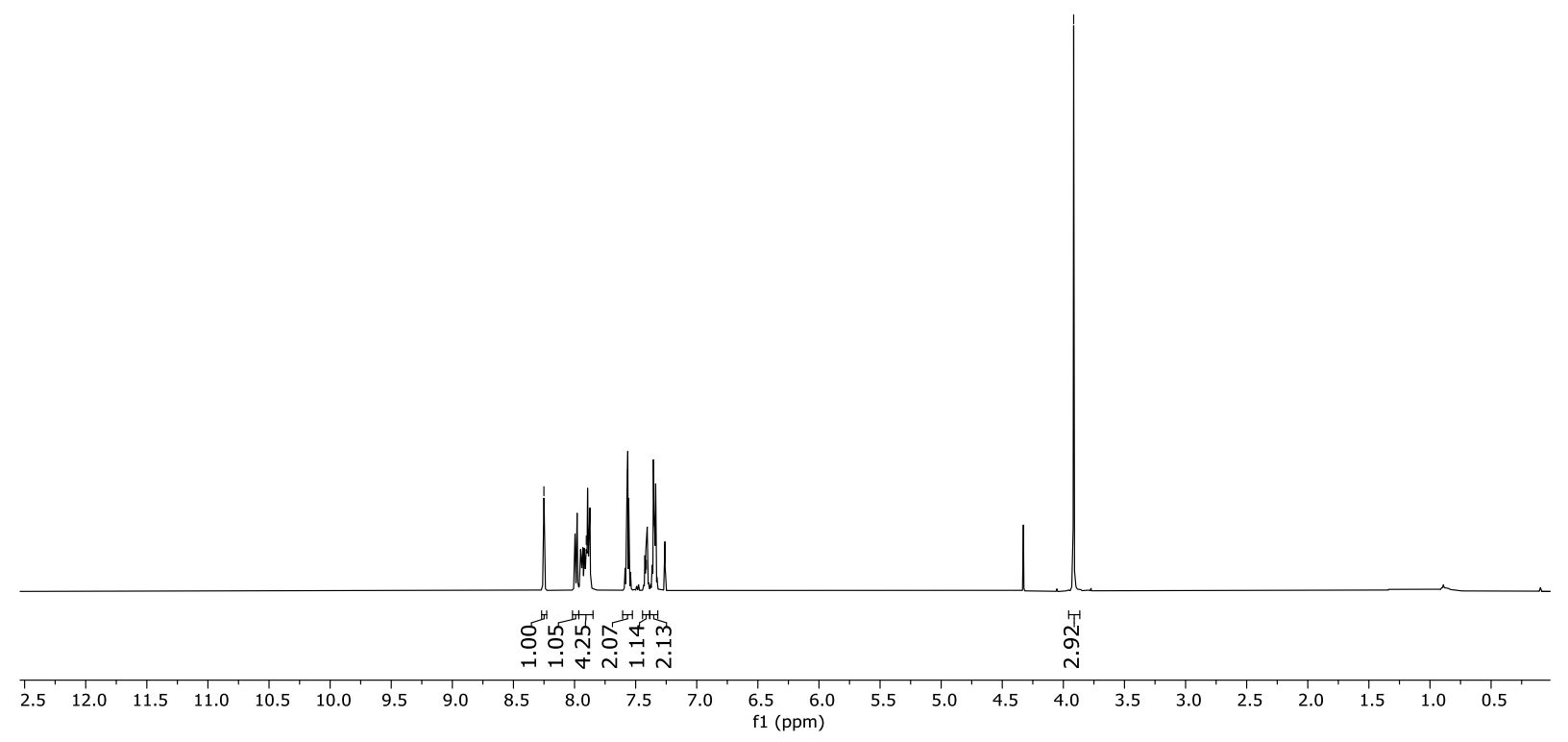

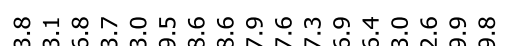

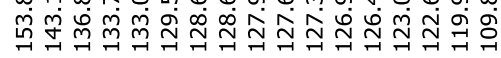

H.

$\stackrel{\circ}{m}$

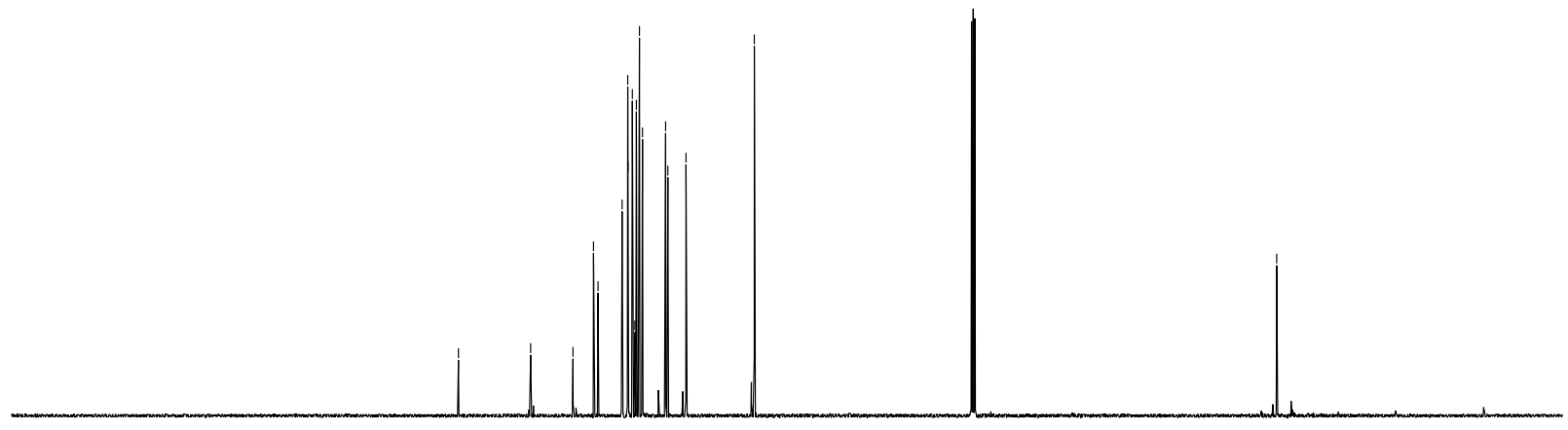

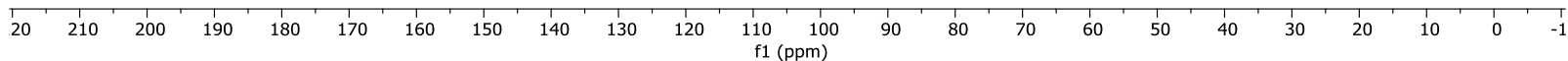



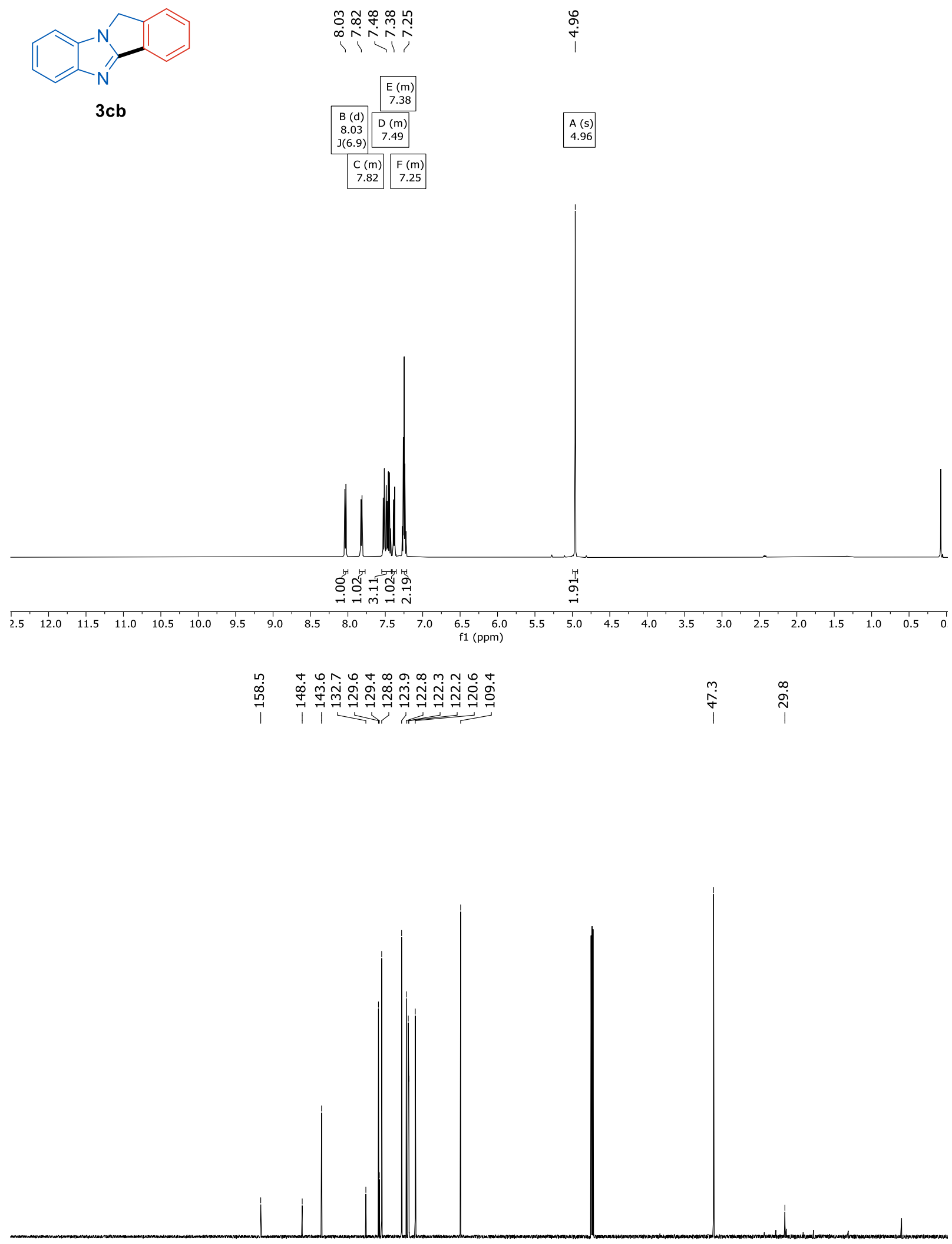

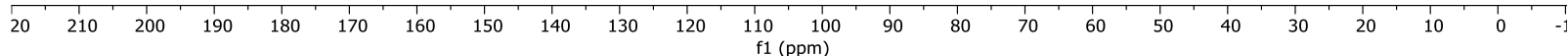




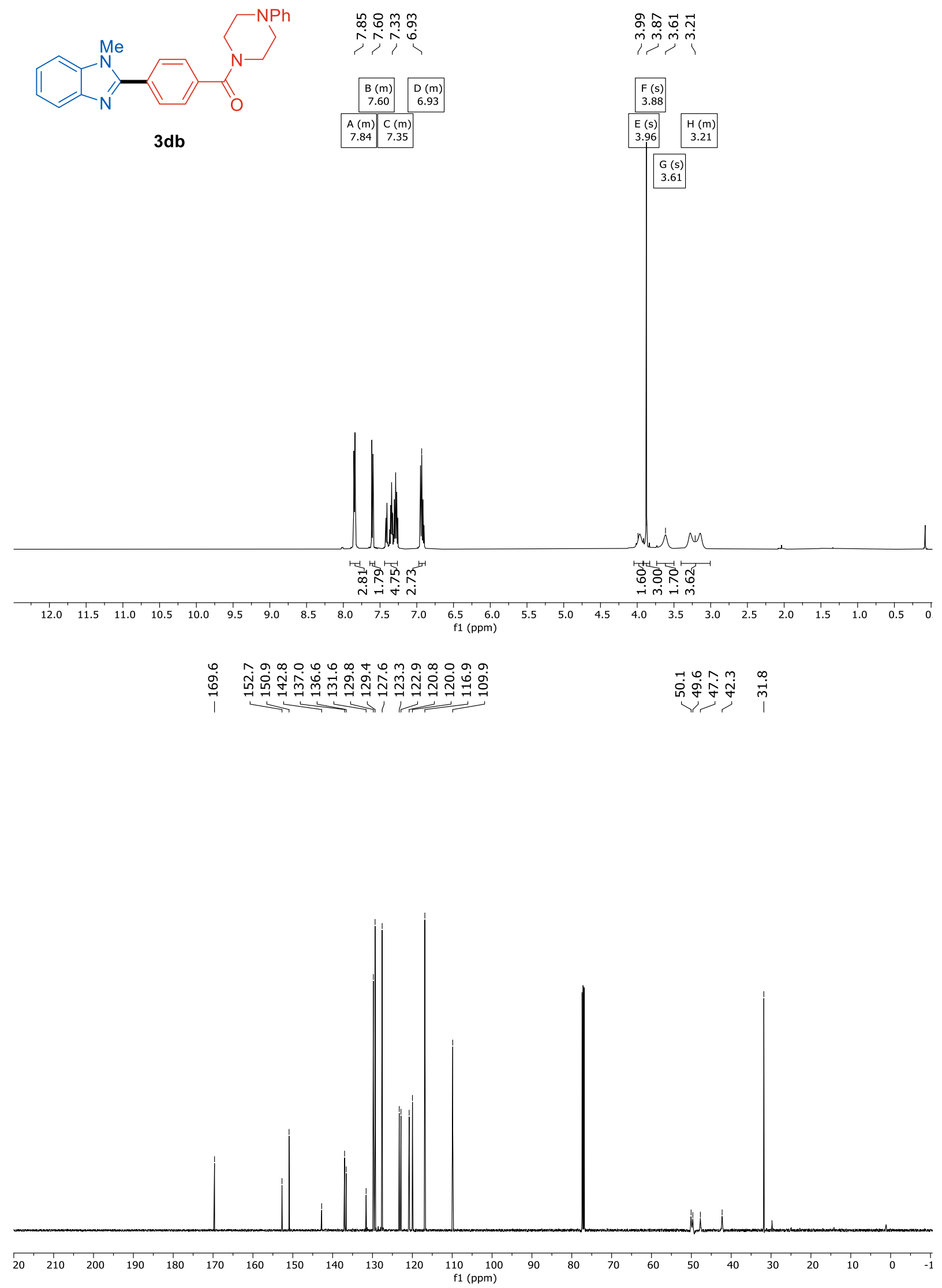




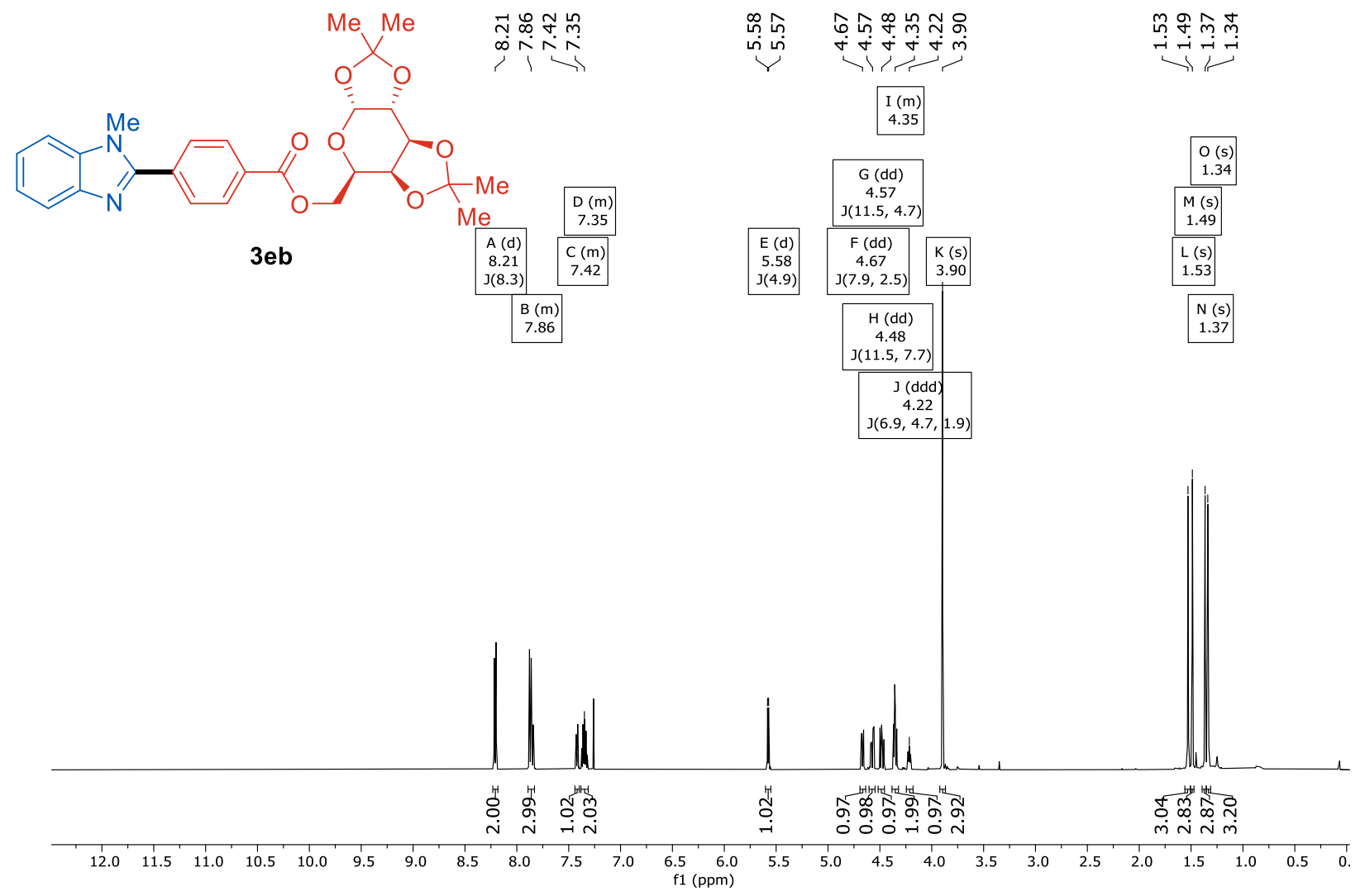

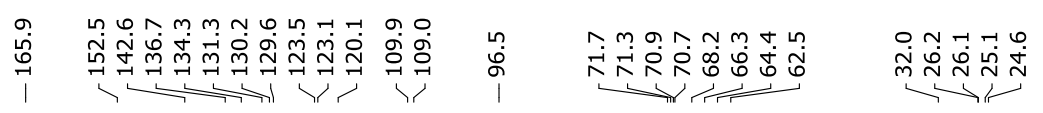

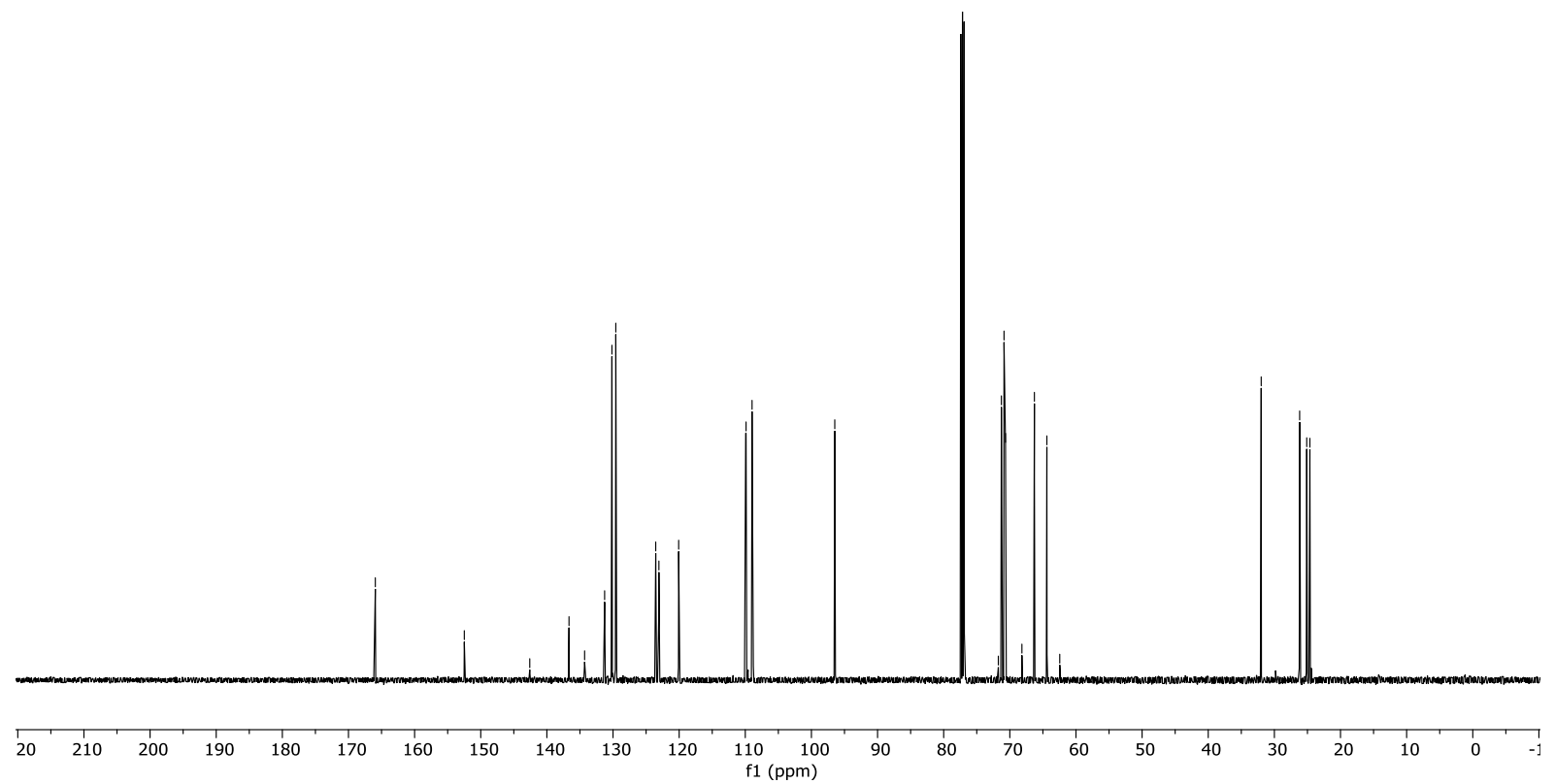

